


\section{Delfstofwinning en Natuur}

Albert Vliegenthart ${ }^{1} \&$ Friso van der Zee $^{2}$

1 De Vlinderstichting, Wageningen

2 Wageningen Environmental Research

Dit onderzoek is uitgevoerd door Wageningen Environmental Research en De Vlinderstichting in opdracht van Cascade Vereniging Zand- en Grindproducenten, in het kader van Life IP (LIFE15 IPE NL 016 Integrated approach N2000 Delta nature, PIC code: 916953708).

Wageningen Environmental Research

Wageningen, maart 2018

Rapport 2873

ISSN 1566-7197 
Vliegenthart, A. \& F.F. van der Zee, 2018. Delfstofwinning en Natuur. Wageningen, Wageningen Environmental Research, Rapport 2873. 96 blz.; 27 fig.; 9 tab.; 27 ref.

\title{
Referaat
}

De afgelopen tientallen jaren heeft de zand- en grindwinnende industrie diverse projecten uitgevoerd waarin delfstofwinning gecombineerd wordt met natuurontwikkeling, waterveiligheid en recreatiegebieden. De industrie wil graag meetbaar en daarmee tastbaarder maken wat de bijdragen van haar projecten tot op heden is geweest op het gebied van biodiversiteit en waterveiligheid. De vraag is hoe de samenhang tussen de verschillende projecten zo veel mogelijk vanuit het oogpunt van natuur/biodiversiteit/waterveiligheid geoptimaliseerd kan worden. Het doel van dit onderzoek is drieledig:

1. Wat is de bijdrage van projecten van delfstofwinning aan de biodiversiteit (Natura 2000)?

2. Wat is de bijdrage van deze industrie op rivierverruiming \& waterveiligheid?

3. Hoe kan de samenhang van projecten van verschillende initiatiefnemers verbeterd worden in relatie tot biodiversiteit?

Het onderzoek toont een positief beeld van de sector op biodiversiteit en waterveiligheid en geeft aanbevelingen hoe dit nog verder verbeterd zou kunnen worden.

\begin{abstract}
Over the past decades, the sand and gravel-winning industry has carried out various projects in which mineral extraction is combined with nature development, water safety and recreational areas. The industry wants to make measurable and therefore more tangible what the contributions of its projects have been to date in the field of biodiversity and flood risk management. The question is how the coherence between the different projects can be optimized as much as possible from the viewpoint of nature / biodiversity / water safety. The aim of this research is threefold:

1. What is the contribution of projects of mineral extraction to biodiversity (Natura 2000)?

2. What is the contribution of this industry to river widening \& flood risk management?

3. How can the coherence of projects of different initiators be improved in relation to biodiversity? The research shows a positive image of the sector on biodiversity and flood risk management and provides recommendations on how this could be improved further.
\end{abstract}

Trefwoorden: Biodiversiteit Zandwinning Grindwinning Waterveiligheid Waterstandsverlaging Life-IP

Dit rapport is gratis te downloaden van https://doi.org/10.18174/443718 of op www.wur.nl/environmental-research (ga naar 'Wageningen Environmental Research' in de grijze balk onderaan). Wageningen Environmental Research verstrekt geen gedrukte exemplaren van rapporten.

2018 Wageningen Environmental Research (instituut binnen de rechtspersoon Stichting Wageningen Research), Postbus 47, 6700 AA Wageningen, T 03174807 00, www.wur.nl/environmental-research. Wageningen Environmental Research is onderdeel van Wageningen University \& Research.

- Overname, verveelvoudiging of openbaarmaking van deze uitgave is toegestaan mits met duidelijke bronvermelding.

- Overname, verveelvoudiging of openbaarmaking is niet toegestaan voor commerciële doeleinden en/of geldelijk gewin.

- Overname, verveelvoudiging of openbaarmaking is niet toegestaan voor die gedeelten van deze uitgave waarvan duidelijk is dat de auteursrechten liggen bij derden en/of zijn voorbehouden.

Wageningen Environmental Research aanvaardt geen aansprakelijkheid voor eventuele schade voortvloeiend uit het gebruik van de resultaten van dit onderzoek of de toepassing van de adviezen.

Wageningen Environmental Research Rapport 2873 | ISSN 1566-7197

Foto omslag: Lobberdense waarden (Albert Vliegenthart) 


\section{Inhoud}

$\begin{array}{ll}\text { Woord vooraf } & 5\end{array}$

$\begin{array}{ll}\text { Dankwoord } & 7\end{array}$

Samenvatting $\quad 9$

$\begin{array}{ll}\text { Summary } & 11\end{array}$

1

Inleiding $\quad 13$

1.1 Aanleiding onderzoek 13

1.2 Life IP Deltanatuur $\quad 13$

$\begin{array}{ll}1.3 & \text { Doel van het onderzoek }\end{array}$

$\begin{array}{lll}1.4 & \text { Kaders } & 15\end{array}$

$\begin{array}{lll}1.5 & \text { Vraagstelling } & 15\end{array}$

$\begin{array}{lrr}2 & \text { Achtergrond } & 17\end{array}$

$\begin{array}{lll}2.1 & \text { Biodiversiteit in het rivierensysteem } & 17\end{array}$

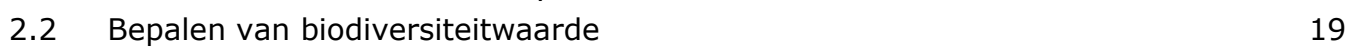

$\begin{array}{ll}2.3 & \text { Nieuwe natuurwaarden }\end{array}$

2.4 Biodiversiteit meten $\quad 21$

$\begin{array}{lll}2.5 & \text { Waterstandverlaging } & 23\end{array}$

$\begin{array}{llr}3 & \text { Methode } & 27\end{array}$

$\begin{array}{lll}3.1 & \text { Gebieden } & 27\end{array}$

$\begin{array}{lll}3.2 & \text { Biodiversiteit } & 29\end{array}$

3.2.1 NDFF en waarnemingsperioden $\quad 29$

3.2.2 Berekening natuurwaarde via natuurpuntensysteem 30

3.2.3 Grootte van de gebieden, waarnemerseffect 31

3.2.4 Welke soorten verdwijnen of verschijnen? 31

$\begin{array}{lll}3.3 & \text { Waterstandverlaging } & 32\end{array}$

$\begin{array}{lll}3.4 & \text { Interviews } & 32\end{array}$

4

$\begin{array}{ll}\text { Resultaten } & 35\end{array}$

4.1 Biodiversiteit $\quad 35$

4.1.1 Natuurwaarden algemeen $\quad 35$

4.1.2 Natuurwaarde afzonderlijke soortgroepen 38

4.1.3 Samenvattend $\quad 41$

4.1.4 Van welke soortgroepen nemen de aantallen soorten toe of af? $\quad 42$

4.1.5 Deelonderzoek Hedelse Bovenwaard 46

$\begin{array}{lll}4.2 & \text { Waterstandverlaging } & 48\end{array}$

$\begin{array}{lll}4.3 & \text { Integrale samenhang } & 50\end{array}$

4.3.1 Delfstofwinning en biodiversiteit 50

4.3.2 Delfstofwinning en waterveiligheid 56

4.3.3 Samenhang en integratie projecten delfstofwinning 58

$\begin{array}{lll}5.1 & \text { Biodiversiteit } & 61\end{array}$

5.1.1 Natuurpuntensysteem \& NDFF-gegevens $\quad 61$

$\begin{array}{ll}5.1 .2 \text { Natuurwaarde } & 62\end{array}$

5.2 Waterstandverlaging $\quad 64$

5.3 Integrale samenhang $\quad 65$

$\begin{array}{lll}5.4 & \text { Conclusies } & 66\end{array}$

$\begin{array}{lll}5.5 & \text { Aanbevelingen } & 68\end{array}$ 
Literatuur

69

Bijlage 1 Soortenlijst 


\section{Woord vooraf}

\section{"Ecologie, Economie en Waterveiligheid gaan hand in hand"}

Jaarlijks voorzien de delfstoffenwinners de Nederlandse bouwwereld van benodigde grondstoffen. Zoals zand en grind voor de productie van beton en asfalt, klei voor de productie van bakstenen en dakpannen maar ook voor de Nederlandse dijken. Ook grondstoffen voor kalkzandsteenproducten en zilverzand worden in Nederland gewonnen. De winning van primaire grondstoffen blijft ook in de toekomst nodig. Hoewel de bouwsector steeds beter wordt in het recyclen van grondstoffen, blijkt uit monitoringgegevens dat hergebruik kan voorzien in 15 tot $20 \%$ van de vraag naar grondstoffen. Binnen de circulaire economie, met aandacht voor "design for re-use" en zodanig gebruik van grondstoffen dat deze in volgende levenscycli eenvoudig terug te winnen en te hergebruiken zijn, zal dit aandeel in de toekomst mogelijk nog kunnen toenemen. Maar ook dan zal een substantiële behoefte aan primaire grondstoffen blijven bestaan.

De winning van primaire grondstoffen betekent natuurlijk een ruimtelijke ingreep in het landschap, maar biedt ook zeker kansen om nieuwe functies te realiseren. Denk daarbij aan natuurontwikkeling, recreatie, waterberging en wonen aan het water. Dit stelt zand- en grindproducenten voor de uitdaging om nieuwe projecten te ontwikkelen die bijdragen aan een betere inrichting en gebruik van gebieden. Een uitdaging die zij graag aangaan. Het zand en grind dat de leden van Cascade winnen, is aangevoerd via onze rivieren. In de loop van vele eeuwen zijn zand en grind afgezet in steeds veranderende rivierbeddingen. Daardoor is het Nederlandse landschap gevormd en ons land tot een unieke delta in Europa geworden. Tegelijkertijd voeren deze rivieren als gevolg van de klimaatverandering meer water af, waardoor het risico op overstromingen toeneemt.

In het LIFE IP project zijn de ogenschijnlijk tegengestelde belangen in het Nederlandse deltagebied onderzocht. Hoe zijn deze aan elkaar te verbinden? De afgelopen tientallen jaren hebben zand- en grindproducenten veel projecten uitgevoerd waarin delfstoffenwinning gecombineerd is met natuurontwikkeling en rivierverruiming. Deze thema's staan centraal in deze studie die mede door subsidie van het Europese LIFE IP fonds mogelijk is gemaakt. Doel van de studie is om objectief inzichtelijk te maken wat de toegevoegde waarde van zand- en grindwinning is voor natuurwaarden en waterveiligheid in de Nederlandse delta.

Het doet ons deugt dat deze studie aantoont dat die bijdrage groot is. Natuurwaarden binnen en nabij zand- en grindwinningen blijken erop vooruit te zijn gegaan. En dankzij de projecten van de Cascadeleden is inmiddels meer dan de helft van de beoogde nieuwe natuur langs de rivieren gerealiseerd en bovendien een aanzienlijke waterstandsverlaging gerealiseerd. En dat alles grotendeels bekostigd uit de winning van delfstoffen ten behoeve van de Nederlandse bouwindustrie. Met trots mogen we vaststellen dat ecologie, economie en waterveiligheid hand in hand gaan in het Nederlandse deltagebied gebied. Ook de komende decennia blijven wij graag onze bijdrage leveren aan de ontwikkeling van nieuwe natuur en rivierverruiming.
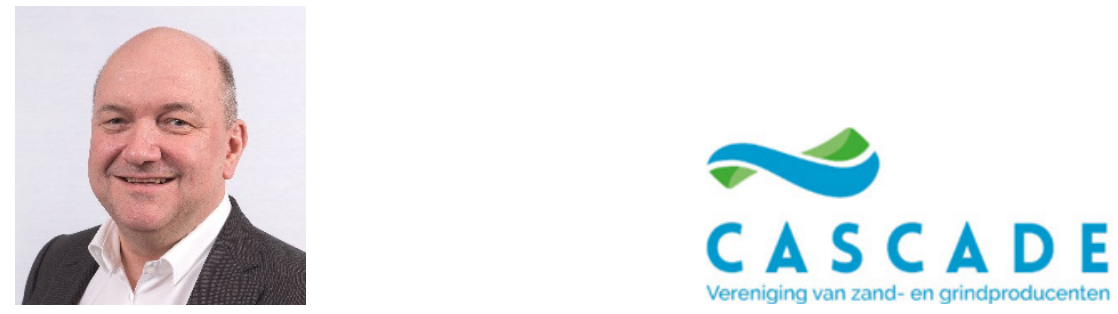

Michiel Dankers

Bestuursvoorzitter Cascade, vereniging van zand- en grindproducenten 


\section{Dankwoord}

Bij de totstandkoming van dit rapport zijn veel mensen betrokken zonder wie de inhoud niet compleet was geweest. Allereerst willen we Leonie van der Voort bedanken voor de opdracht van dit onderzoek binnen het LIFE-IP-project.

Het onderzoek bestaat uit verschillende invalshoeken en zoals LIFE-IP aangeeft betreft het vooral de samenhang binnen de zand- en grindwinningindustrie. Hiervoor zijn leuke en interessante interviews gevoerd met de betrokken bedrijven. We willen Vivien L'Ortye, Richard van den Berg, Mirjan Bottinga, Reinier de Poorter, Herman van de Linde, Jeroen Coppes, Jaap Deutekom, Koen van Aanholt, Iwan Reerink bedanken voor de gastvrijheid en het geduld bij al onze vragen op kantoor, maar ook zeker in het veld. Het was mooi om de bevlogenheid te zien bij al deze mensen.

Een bijzondere ervaring mochten we mee maken op de Rotterdam 55, waar Richard van den Berg ons een rondleiding verzorgde. Vanuit Cascade waren Leonie van der Voort en Sandra de Wit aanwezig. Mooi om het proces van zand- en grindwinning een keer van dichtbij mee te maken.

Als ecologen hebben we onze kennis over de rivierdynamiek laten bijschaven door Ron Agtersloot (Agtersloot Hydraulisch Advies). Om dit onderzoek objectief uit te voeren, hebben we ook gesprekken gevoerd met de Gelderse Milieufederatie (Alex de Meijer en Roelof van Loenen Martinet (Waterschap Rivierenland) en het Wereld Natuurfonds (Michiel van den Bergh).

Tijdens de onderzoeksperiode werden we bijgestaan door enthousiaste studenten. Lisa van de Put (Radbout Universiteit) en Ilan Slangen (Aeres Hogeschool Almere). Zij hebben vooral naar de impact van winningen op biodiversiteit gekeken en het gebruik van het natuurpuntensysteem onderzocht.

\section{Albert Vliegenthart \& Friso van der Zee}




\section{Samenvatting}

De afgelopen tientallen jaren heeft de zand- en grindwinnende industrie veel projecten uitgevoerd waarin delfstofwinning gecombineerd wordt met natuurontwikkeling, waterveiligheid en recreatie. De industrie wil graag meetbaar en daarmee meer tastbaar maken wat de bijdragen van haar projecten tot op heden is geweest op het gebied van biodiversiteit en waterstandverlaging (rivierveiligheid). Daarnaast is het van belang te weten hoe het bedrijfsleven haar toekomstige projecten vormgeeft, zodat Natura 2000 optimaal bediend wordt. De vraag is hoe de samenhang tussen de verschillende projecten zo veel mogelijk vanuit het oogpunt van natuur/ biodiversiteit/waterveiligheid geoptimaliseerd kan worden.

Met het programma LIFE IP Deltanatuur worden (ogenschijnlijk) tegengestelde belangen onderzocht. Wat is ieders rol en verantwoordelijkheid en hoe zijn die te verbinden? Cascade, de vereniging van zand- en grindproducenten is een van de partners in Life IP Deltanatuur. Het programma LIFE IP Deltanatuur komt voort uit Natura 2000. Dit is een Europees netwerk van natuurgebieden waarin men flora en fauna duurzaam wil beschermen. Het doel van dit onderzoek is drieledig:

1. In beeld brengen wat de bijdrage van projecten van delfstofwinning is aan de biodiversiteit (Natura 2000 doelstelling).

2. In beeld brengen wat de bijdrage van deze industrie is op rivierverruiming \& waterveiligheid.

3. Het bepalen van een methode om de samenhang van projecten van verschillende initiatiefnemers vanuit biodiversiteit optimaal op elkaar af te stemmen.

Voor de analyse (hoe de biodiversiteit beïnvloed is door delfstofwinning) is een natuurpuntensysteem gebruikt om voor 24 gebieden de natuurwaarde te berekenen voor en na de winning. Dit natuurpuntensysteem is nog in ontwikkeling en is speciaal voor dit project aangepast. De soortgegevens zijn afkomstig uit de Nationale Databank Flora en Fauna. Voor de bijdrage van de industrie aan rivierverruiming is aan 9 geselecteerde bedrijven gevraagd gegevens aan te leveren over het aantal gerealiseerde centimeters aan waterstandverlaging in de verschillende projecten. Voor de samenhang zijn interviews gehouden met de projectleiders en/of directieleden van zand- en grindwinbedrijven. Een aantal aanvullende technische vragen is achteraf via een speciaal ontwikkeld Google-formulier gesteld.

Bij de vergelijking van de aantallen soorten aangetroffen voor en na de delfstofwinning in 24 gebieden, is vrijwel overal de biodiversiteit na afloop groter. Dagvlinders, vaatplanten en vogels vertonen de sterkste stijging in aantal. Ook het aantal soorten libellen gaat vooruit. Alleen het aantal soorten vissen is lager na de winning dan voor de winning. Bij de toename gaat het vooral om algemene soorten, bij de Rode Lijstsoorten en referentiesoorten is de toename veel minder groot. De toename betreft met name soorten van natte milieus en oevers, de doelsoorten van stroomdalgraslanden en vochtige ooibossen nemen nog niet sterk toe.

Onder invloed van de delfstofwinnende industrie zijn in het rivierengebied tal van nieuwe natuurgebieden gerealiseerd. Een selectie van 28 projecten in dit onderzoek levert 3400 ha nieuwe natuur op. Dit is al de helft van de doelstelling 7000 ha nieuwe natuur in 2015 langs de grote rivieren die Rijkswaterstaat heeft afgesproken met het Ministerie van LNV. De natuurgebieden liggen als een kralenketting langs de rivier, waarbij de rivier zelf de robuuste verbinding vormt, zeker als het gaat om de natte natuur.

De delfstofwinnende industrie levert met zand- en grindwinprojecten een aanzienlijke bijdrage aan de waterveiligheid. In totaal leveren de 28 projecten uit dit onderzoek ruim $370 \mathrm{~cm}$ waterstandverlaging in de rivier op. Hoe deze bijdrage zich verhoudt tot andere 'Ruimte voor de Rivier'-projecten, valt moeilijk met harde cijfers uit te drukken. Door experts wordt ingeschat dat die verhouding ca. 50-50 is. 
De sector fungeert duidelijk als motor voor gebiedsontwikkeling. Veel van de huidige nieuwe natuur bij terreinbeherende organisaties in het rivierengebied zou zonder de sector niet gerealiseerd zijn. De realisatie van nieuwe natuur en waterveiligheid door de delfstofwinnende industrie is voor Nederland aantrekkelijk. Natuurontwikkeling en waterveiligheid worden op kosten van het bedrijfsleven gerealiseerd en daarmee in feite gratis voor de BV Nederland.

De mate waarin bedrijven zich met natuur en biodiversiteit bezighouden, verschilt per bedrijf. Sommige bedrijven profileren zich sterk op dit vlak met veel pr. Anderen zien zich meer sec als uitvoerder en laten deze aspecten over aan het consortium of, als het om belangenbehartiging en imago gaat, aan Cascade. Over het geheel genomen is de sector erg bescheiden over de gerealiseerde natuur, veel van de erkenning belandt bij partijen als Natuurmonumenten of andere organisaties die het gebied na afloop van de winning beheren.

Regelgeving als het Programma Aanpak Stikstof (PAS) wordt soms als knellend ervaren. Dit komt mede door de lange termijnen van projecten (20-30 jaar) en de korte termijnen van de beheerplannen Natura 2000. Zaken als tijdelijkheid van winningsprojecten in een gebied en het uiteindelijk netto positieve effect op stikstofdepositie worden daardoor gemist en niet gesaldeerd binnen het PAS. Ook is de vergunningsverlening heel gedetailleerd, waarbij de handhaving bij oplevering strikt kijkt naar wat ooit is afgesproken (bijv. afmetingen profiel), terwijl bij dynamische riviernatuur meer flexibiliteit past.

Op basis van het onderzoek komen wij tot de volgende aanbevelingen:

- De bijdrage van de sector aan natuur en waterveiligheid is hoog. Qua prioritaire Natura 2000 habitattypen kan extra aandacht gegeven worden aan 'stroomdalgrasland' en 'vochtige ooibossen'. Dit vereist extra aandacht in de planfase, maar ook in uitvoering (geschikt maken milieu, evt. inbrengen gewenste soorten via maaisel o.i.d.) en het beheer na afloop.

- Een uitontwikkeld natuurpuntensysteem met draagvlak bij overheden (de provincie is voor deze branche het bevoegd gezag) zou helpen bij het eenvoudig objectief vaststellen van natuurwaarden en daarmee het bepalen van toegevoegde waarde van projecten. Deze waarde kan dan ook in de footprint van de geproduceerde grondstoffen worden meegewogen.

- Er kan veel meer pr voor de goede resultaten op het gebied van biodiversiteit en waterveiligheid gemaakt worden, de sector is op dit vlak zeer bescheiden. Die bescheidenheid is onnodig en de sector mag haar successen best meer uitdragen in bijeenkomsten. Een voorbeeldenboek van goed geslaagde projecten, liefst gemaakt door een onafhankelijke derde partij, kan daarbij ook helpen.

- Gebieden na afloop van de winning in eigen beheer houden vergroot de mogelijkheid om de credits voor natuur vanzelfsprekender bij de sector terecht te laten komen En er ontstaat ook meer inhoudelijke kennis over natuurbeheer. 


\section{Summary}

Over the past decades, the sand and gravel-winning industry has carried out many projects in which mineral extraction is combined with nature development, water safety and recreation. The industry wants to make the contributions of its projects to date have been in the area of biodiversity and water level reduction (river safety) measurable and therefore more tangible. In addition, it is important to know how the business world can design its future projects, so that Natura 2000 is best served. The question is how the coherence between the different projects can be optimized as much as possible from the viewpoint of nature / biodiversity / water safety.

The LIFE IP (Integrated Projects) Delta Declaration program examines (apparently) conflicting interests. What is everyone's role and responsibility and how can they be connected? CASCADE, the association of sand and gravel producers, is one of the partners in Life IP Delta Nature. The LIFE IP Delta Nature program originates from Natura 2000. This is a European network of protected areas where flora and fauna are protected in a sustainable way. The aim of this research is threefold:

1. Identify the contribution of projects of mineral extraction to biodiversity (Natura 2000 objective).

2. Identify the contribution of this industry to river widening \& flood risk management.

3. Determining a method to coordinate the projects of different initiators in order to maximize biodiversity.

For the analysis (how biodiversity was influenced by mineral extraction), a points system was used to calculate the natural value of 24 areas before and after extraction. This nature point system is still under development and has been specially adapted for this project. The species data are from the National Flora and Fauna Database. For the contribution of the industry to river widening, 9 selected companies were asked to provide data on the number of centimetres of water level reduction in the various projects. For consistency, interviews were held with the project leaders and / or board members of sand and gravel companies. A number of additional technical questions were made afterwards via a specially developed Google form.

When comparing the numbers of species found before and after mineral extraction in 24 areas, biodiversity is greater nearly everywhere afterwards. Butterflies, vascular plants and birds show the strongest increase in numbers. The number of dragonfly species is also improving. Only the number of species of fish is lower after extraction than before extraction. The increase mainly concerns general species, for the Red List species and reference species the increase is much less. The increase concerns particular types of wetlands and banks, the target species of dry river grasslands and wetland forests are not yet increasing strongly.

Under the influence of the mineral extraction industry, numerous new nature reserves have been realized in the river area. A selection of 28 projects in this study yields 3400 hectares of new nature. This is already half of the target 7000 ha of new nature in 2015 along the major rivers that 'Rijkswaterstaat' has agreed with the Ministry of Agriculture, Nature and Food Quality. The nature reserves lie like a necklace along the river, where the river itself forms the robust connection, especially when it comes to wet nature.

The mineral extraction industry makes a significant contribution to flood risk management with sand and gravel projects. In total, the 28 projects from this study provide a good $370 \mathrm{~cm}$ drop in water levels in the river. How this contribution relates to other 'Room for the River' projects is difficult to express with hard figures. It is estimated by experts that this ratio is approximately $50-50$.

The sector clearly functions as a driver for the environment. Much of the current new nature among nature management organizations in the river area would not have been realized without the sector. The realization of new nature and water safety by the mineral extraction industry is attractive for the Netherlands. Nature development and flood risk management are realized at the expense of the business community and thus in fact free of charge for BV Netherlands. 
The degree to which companies deal with nature and biodiversity differs per company. Some companies are profiling themselves strongly in this area with a lot of PR. Others see themselves more as a supervisor and leave these aspects to the consortium or, if it concerns advocacy and image, to Cascade. On the whole, the sector is very modest about the realized nature, much of the recognition ends up with parties like 'Natuurmonumenten' or other organizations that manage the area after the extraction.

Regulations such as the Nitrogen Approach Program (PAS) are sometimes perceived as restricting. This is partly due to the long terms of projects (20-30 years) and the short terms of the Natura 2000 management plans. Issues such as the temporary nature of extraction projects in an area and the eventual net positive effect on nitrogen deposition are therefore missed and not netted within the PAS. The granting of permits is also very detailed, with enforcement on completion strictly complying with what has ever been agreed (e.g. dimensions profile), while with dynamic river nature more flexibility would fit.

Based on the research we come to the following recommendations:

- The sector's contribution to nature and flood risk management is high. In terms of priority Natura 2000 habitat types, extra attention can be given to 'dry river grassland' and 'wetland forest'. This requires extra attention in the planning phase, but also in execution (making the environment suitable, if necessary introducing desired species via cuttings etc.) and the management afterwards.

- An elaborated natural points system with support from governments (the province is the competent authority for this branch) would help in the objective determination of nature values and thus determining the added value of projects. This value can also be taken into account in the footprint of the raw materials produced.

- Much more pr for the good results in the area of biodiversity and flood risk management can be made, the sector is very modest in this area. This modesty is unnecessary and the sector should best propagate its successes in meetings. A sample book of well-done projects, preferably made by an independent third party, can also help.

- Keeping areas under own management after the end of the extraction increases the possibility of allowing the credits for nature to become more self-evident in the sector. And more substantive knowledge about nature management is also created. 


\section{$1 \quad$ Inleiding}

\subsection{Aanleiding onderzoek}

De afgelopen tientallen jaren heeft de zand- en grindwinnende industrie veel projecten uitgevoerd waarin delfstofwinning gecombineerd wordt met natuurontwikkeling, waterveiligheid en recreatie. Gezien de opgave in het Deltaprogramma (rivieren) zal deze industrie volop doorgaan met haar activiteiten, zeker ook gezien de toekomstige vraag naar primaire bouwgrondstoffen die bij voorkeur in Nederland gewonnen moeten worden (milieu footprint). De industrie wil graag meetbaar en tastbaar maken wat de bijdragen van haar projecten tot op heden is geweest op het gebied van biodiversiteit. Daarnaast is het van belang te weten hoe het bedrijfsleven haar toekomstige projecten vormgeeft, zodat Natura 2000 optimaal bediend wordt. De vraag is hoe de samenhang tussen de verschillende projecten zo veel mogelijk vanuit het oogpunt van natuur/biodiversiteit versterkt en/of geoptimaliseerd kan worden.

Een tweede aspect is de betekenis van delfstofwinning (zand en grindwinning) bij de realisatie van waterveiligheid in het rivierengebied. Hier gaat het om de creatie van snellere afvoer bij hoge piekwaterstanden en wat de delfstofwinnende industrie daaraan bijdraagt.

\subsection{Life IP Deltanatuur}

Wie als een vogel boven Nederland zweeft, ziet een veelkleurige deltanatuur. Blauwe rivieren, groene uiterwaarden, spiegelende meren, het zand van wad en duin, met daaromheen het leigrijs van de Noordzee. Deze delta herbergt unieke natuur, maar staat onder druk. Menselijke activiteiten, zoals landbouw, visserij en de aanleg van dammen, dijken en polders hebben tot veiligheid en welvaart geleid. Maar ze verstoren ook waterloopkundige en ecologische processen. Ecosystemen zijn niet stabiel en soorten en leefgebieden zijn verdwenen of worden bedreigd.

Overheid, natuurorganisaties, waterbeheerders en bedrijven willen gezamenlijk de natuur in de grote wateren herstellen en verder ontwikkelen. Dit gaat soms moeizaam door spanningen tussen veiligheid, economie en ecologie. Ook ontbreekt een samenhangende aanpak en is er onduidelijkheid over rollen en verantwoordelijkheden van de betrokken partijen. Verder is het de vraag of de richtlijnen van Natura 2000 wel steeds voldoende ruimte bieden voor de gewenste en zelfstandige ontwikkeling van de deltanatuur.

\section{Programma LIFE IP Deltanatuur (2016-2022)}

Met het programma LIFE IP Deltanatuur worden botsende belangen onderzocht. Wat is ieders rol en verantwoordelijkheid en hoe zijn die te verbinden? Om ten slotte tot gezamenlijke oplossingen te komen, wordt op veel plekken gestreefd naar natuurinclusieve plannen en programma's. Dit zijn de kraamkamers van integrale gebiedsvisies. Zo ontstaan er nieuwe ideeën en kruisbestuiving tussen partijen. Het streven is een symbiose van natuur, mens en maatschappij.

Cascade, de vereniging van zand- en grindproducenten, is een van de partners in Life IP Deltanatuur. Samen met alle partners geeft het programma LIFE IP Deltanatuur een impuls aan de ontwikkeling van waardevolle deltanatuurgebieden in Nederland. Het programma LIFE IP Deltanatuur komt voort uit Natura 2000. Natura 2000 is een Europees netwerk van natuurgebieden waarin belangrijke flora en fauna voorkomen. Met Natura 2000 wil men deze flora en fauna duurzaam beschermen. Het beschermen van natuurgebieden op het vasteland lukt, het verrijken van 'natte' natuurgebieden, de zogenoemde grote wateren, lukt onvoldoende. 
Uit analyse blijkt dat daarbij verschillende factoren een rol spelen. Zo is er bij directbetrokkenen, zoals beheerders, gebruikers, gemeenten, natuurorganisaties en waterschappen onduidelijkheid over rollen en verantwoordelijkheden. Daarnaast is er onvoldoende synergie tussen diverse grote uitvoeringsprogramma's die betrekking hebben op veiligheid, waterkwaliteit en natuur. Ook de richtlijnen van Natura 2000 lijken niet voldoende ruimte te bieden aan de natuurontwikkeling van de grote wateren.

Met het programma LIFE IP Deltanatuur wordt getracht antwoord te geven op deze knelpunten en zo een 'boost' te geven aan de bescherming van Europa's waardevolste en meest bedreigde soorten en leefgebieden in Nederland, samen met alle partners. De partners binnen het programma LIFE IP Deltanatuur zullen het natuurbelang met andere activiteiten en functies - zoals waterkwaliteit, waterveiligheid en economische belangen - combineren.

\section{LIFE en de Europese Unie}

LIFE is het programma van de Europese Unie voor de ontwikkeling en uitvoering van het Europese natuur- en milieubeleid. De ministeries van Infrastructuur en Waterstaat (I\&W) en Landbouw, Natuur en Voedselkwaliteit (LNV) zijn verantwoordelijk voor de uitvoering van LIFE in Nederland. Het programma ondersteunt ontwikkelings-, implementatie-, monitorings-, evaluatie- en communicatieprojecten op het gebied van onder meer natuur en biodiversiteit (onder meer het verbeteren van Natura 2000-gebieden).

LIFE IP Deltanatuur is een zogenoemd integraal project. Het is bedoeld als katalysator om een integraal en strategisch plan voor de aanpak van de milieu- of klimaatproblemen van een omvangrijk geografisch gebied van A tot $Z$ te implementeren, (multi)regionaal of (inter)nationaal. De nadruk ligt op coördinatie en verbondenheid van alle relevante partijen. De onderwerpen komen voort uit Europese milieu- en klimaatwetgeving en omvat onder meer het onderwerp natuur (management meerdere Natura 2000-gebieden tegelijk, uitvoering van het Prioritized Action Framework (PAF) N2000).

\section{Deltanatuur 'de vijf grote wateren'}

De focus ligt op de zogenaamde 'natte' Natura 2000-gebieden in Nederland, waar de ontwikkeling achterloopt ten opzichte van de 'droge' gebieden. Het gaat in dit programma dus specifiek om de belemmeringen en knelpunten in de vijf grote wateren (= de Deltanatuur) en de directe omgeving (kusten, dijken, maar ook internationale raakvlakken): Noordzee, Waddenzee, IJsselmeer, Rivierengebied, Zuidwestelijke Delta.

Het programma LIFE IP Deltanatuur is opgedeeld in zogenoemde A-, C-, D-, E- en F-acties. Bij de Aacties staat onderzoek naar knelpunten centraal. De C-acties zijn de pilotprojecten, waarin geoefend wordt met het wegnemen van de knelpunten. Bij de D-acties draait het om monitoring, bij de E-acties om communicatie en de F-acties betreffen het programmamanagement. Daarnaast zijn er nog verbredingsacties. Het project in dit rapport is een C1-actie: Natuurontwikkeling combineren met andere functies. Een solide model ontwikkelen voor samenwerking gericht op wederzijdse voordelen voor N2000 en andere functies (waterveiligheid / hoogwaterbescherming, zoetwatervoorziening, recreatie en visserij).

\subsection{Doel van het onderzoek}

Het doel van dit onderzoek is drieledig:

1. In beeld brengen wat de bijdrage van projecten van delfstofwinning is aan de biodiversiteit (Natura 2000-doelstelling).

2. In beeld brengen wat de bijdrage van deze industrie is op rivierverruiming \& waterveiligheid.

3. Hoe kan richting gegeven worden aan toekomstige projecten, dusdanig dat de natuur optimaal kan profiteren van nieuwe projecten met kansen voor N2000? Hoe kan de samenhang van eigenstandige projecten van verschillende initiatiefnemers vanuit biodiversiteit optimaal op elkaar worden afgestemd (voorkomen versnippering en/of onderbreking van netwerken van natuur waaronder Natura 2000)? Waar liggen kansen voor Natura 2000-doelen en waar bedreigingen? 
Wat betekent dit voor de keuzes die provincie/ministerie in hun natuurbeleid ten aanzien van N2000-doelen kunnen maken om daarmee het bedrijfsleven te faciliteren bij de realisatie van N2000-doelen? Belangrijk is dat initiatiefnemers graag vrijwillig meewerken. Met name dit gedeelte van het onderzoek heeft betrekking heeft op de Integrated Projects doelstelling van Life.

\section{$1.4 \quad$ Kaders}

Het project zal op diverse wijzen bijdragen aan de Natura 2000-doelen. Het is van belang te weten hoe het bedrijfsleven haar toekomstige projecten dusdanig inricht zodat Natura 2000 optimaal bediend wordt en hoe de samenhang tussen de verschillende projecten zo veel mogelijk vanuit het oogpunt van natuur/biodiversiteit versterkt en/of geoptimaliseerd kan worden.

Dit onderzoek beperkt zich tot de winningen langs en aan de grote Nederlandse rivieren. Deze liggen doorgaans net buiten Natura 2000-gebied, maar moeten vaak wel rekening houden met de Natura 2000-doelstellingen omdat deze raakvlakken kennen. Hoe kunnen deze projecten optimaal bijdragen aan de doelen van Natura 2000? Op dit moment leveren de projecten bijdragen aan biodiversiteitsdoelen waarbij de individuele delfstofwinner een plan maakt (of laat maken) dat wellicht nog optimaler afgestemd kan worden op alle relevante N2000-gebieden. Ook de samenhang met andere delfstofprojecten in het gebied is niet altijd zeker, met name als projecten door verschillende delfstofwinners worden uitgevoerd. Vaak liggen zand- of grindwinprojecten als losse parels langs de rivier en een betere integratie van deze projecten en een landschapsecologische benadering kan de bijdrage aan Natura 2000-doelen vergroten. Natuurprojecten na delfstofwinning kunnen nog meer dan nu het geval is als stepping stones en verbindingszones voor soorten en habitat van Natura 2000gebieden fungeren.

Dit LIFE IP-project beoogt hierbij behulpzaam te zijn. Te denken valt bijvoorbeeld aan protocollen die gevolgd kunnen worden volgens welke een delfstofwinner te werk gaat. Belangrijk is dat men enthousiast is en blijft om eraan mee te werken. Extra aandacht zal uitgaan naar de prioritaire Natura 2000-habitats, waarvan er in heel Nederland 11 zijn benoemd. In het rivierengebied betreft het de stroomdalgraslanden (H6120) en de vochtige alluviale bossen (H91E0).

De Rijksnatuurvisie 2014 schetst een visie op het publieke belang van toekomstbestendige natuur. Het kabinet wil een robuuste en veelzijdige natuur die de invloed van de samenleving kan verdragen. Deze natuur moet passen bij het veranderende klimaat, maximaal aansluiten bij natuurlijke processen, duurzaam zijn, betaalbaar en toekomstbestendig natuurbeheer en haalbare doelen hebben.

\subsection{Vraagstelling}

\section{Ad 1) Delfstofwinning en biodiversiteit}

- Hoeveel van de huidige riviernatuur is geheel of gedeeltelijk ontstaan als resultante vanuit de delfstofwinning?

- Hoeveel procent is dat van het geheel aan riviernatuur? (Kwantiteit)

- Welke Habitats zijn hierdoor toegenomen? (Kwaliteit)

- Welke zeldzame/bedreigde soorten F\&F Natura 2000 hebben hier met name baat bij?

- Welke rol kan 'robuuste natuur' spelen bij het behalen van Natura 2000-doelstellingen op winlocaties?

- Hoe is biodiversiteit tot op heden gewaardeerd en heeft dit economische waarde opgebracht?

\section{Ad 2) Delfstofwinning en waterveiligheid}

- Waar heeft zand- en grindwinning een rol gespeeld bij het realiseren van de rivier-/waterveiligheidsdoelstelling?

- Hoeveel mm waterstandverlaging is gerealiseerd door middel van delfstofwinning (maak onderscheid in overheidsopdrachten en overige projecten)?

- Waar kan delfstofwinning in de toekomst een vanzelfsprekender rol krijgen in het kader van het Delta Programma en wat moet hiervoor gebeuren?

- Waar liggen de kansen om waterveiligheid optimaal te koppelen aan biodiversiteit? 


\section{Ad 3) Samenhang en integratie projecten delfstofwinning}

- Hoe kan meer samenhang tussen de individuele projecten van delfstofwinning bereikt worden op het thema biodiversiteit en Natura 2000?

- Hoe kan bereikt worden dat delfstofwinners hier enthousiast en vrijwillig aan mee gaan werken?

- Welke uniforme formule kan worden gehanteerd om de kwaliteit van winlocaties op het gebied van biodiversiteit te waarderen?

- Welke verbindende factor is van toepassing om de individuele winlocaties van een gezamenlijke strategie te voorzien?

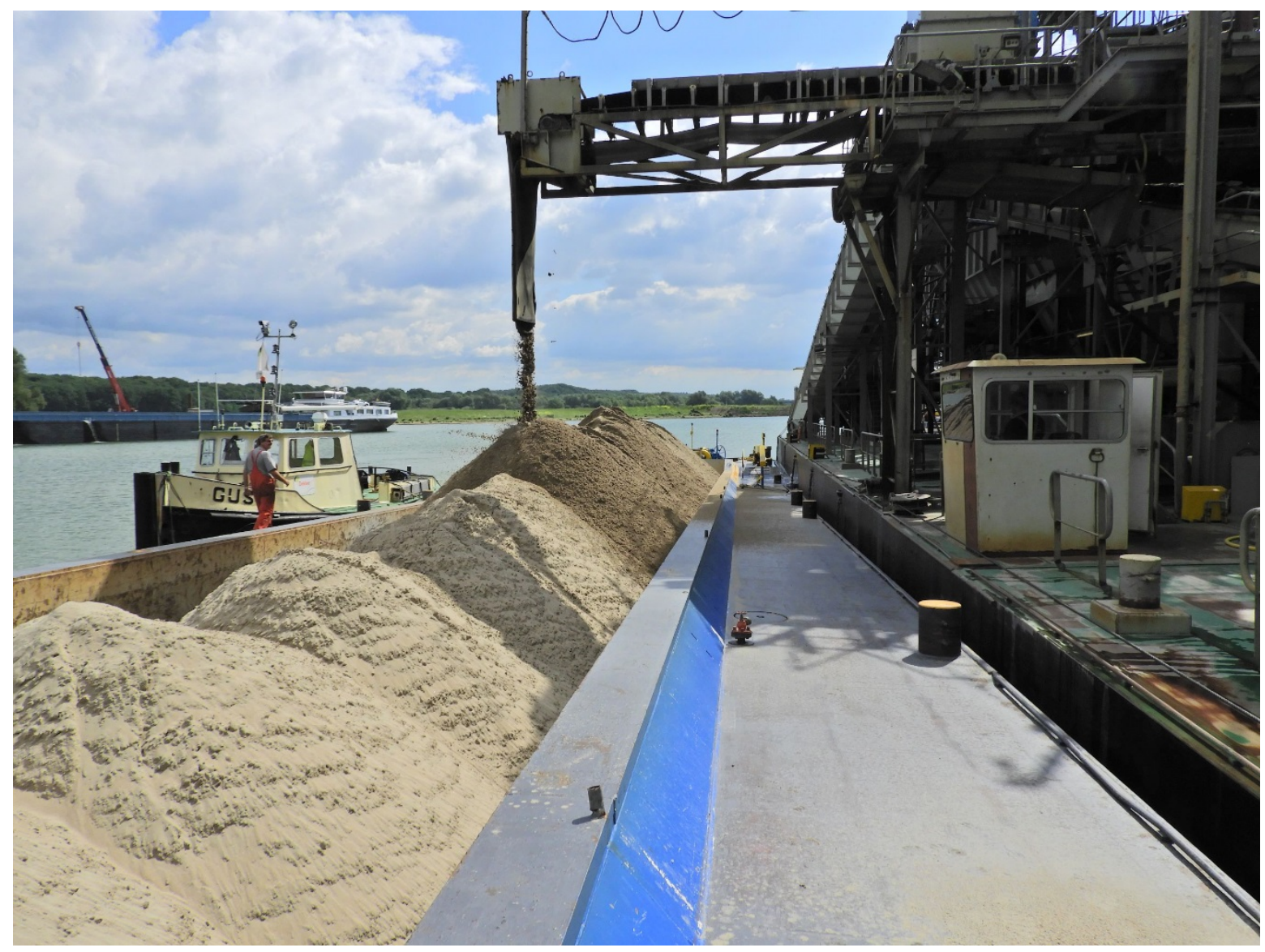

Foto 1 Zandwinning op de Rotterdam 55 in de Randwijkse waarden (Foto: Friso van der Zee). 


\section{Achtergrond}

\subsection{Biodiversiteit in het rivierensysteem}

\section{Rivierdynamiek}

De dynamiek van rivieren zorgt van nature voor een kenmerkende biodiversiteit en ieder riviertraject heeft een eigen karakter. Zo heeft de Grensmaas met haar grindoevers een groter verval en stroomt sneller dan de Rijn en de Waal, die een constantere wateraanvoer hebben. De rivieren in Oost- en Zuid-Nederland stromen door de zandgronden en kennen een relatief brede meandering en hebben hogere oeverwallen. In de Betuwe zijn de rivierbedden wat rechter en liggen in komkleigebieden. West-Nederland kenmerkt zich meer als een delta en heeft een vlechtwerk van rivieren die trager stromen en een zoetwatergetijde hebben.

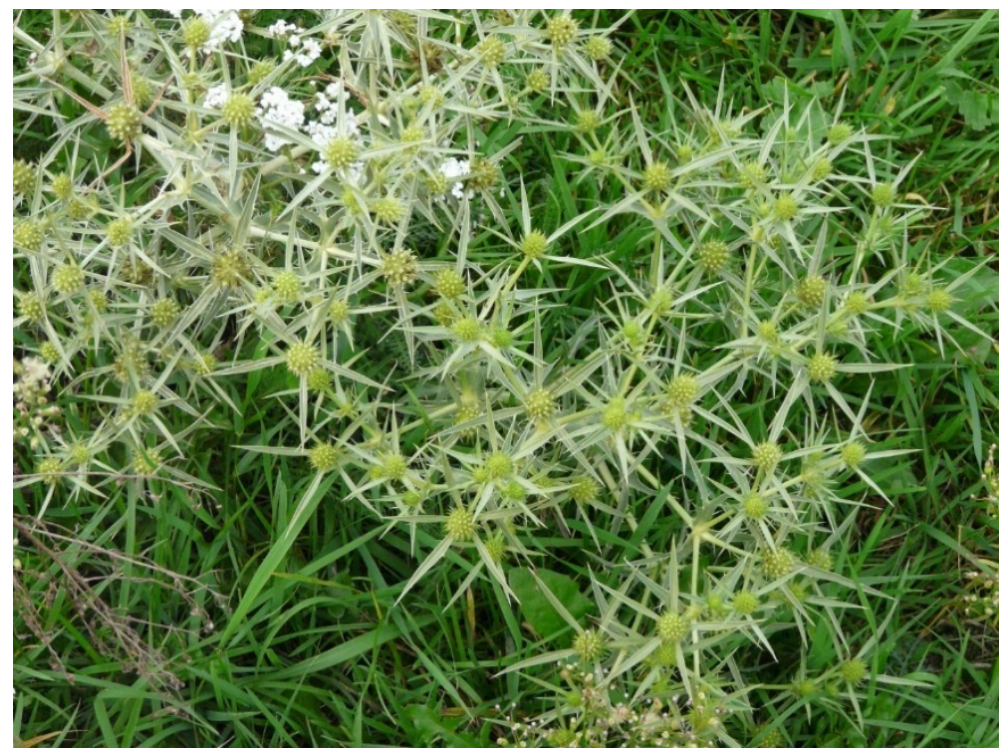

Foto 2 Kruisdistel, een stroomdalplant die het goed doet in begraasde landschappen (Foto: Friso van der Zee).

Biodiversiteit is afhankelijk van variatie en structuur. Deze factoren zijn ruimschoots vertegenwoordigd in het rivierensysteem. Naast rivieren zelf behoren ook nevengeulen (meestromend en eenzijdig aangetakt) en oude rivierarmen (die weer verschillende effecten hebben op erosie en sedimentatie) tot het rivierensysteem. Binnen het systeem is zowel stromend als stilstaand water aanwezig. De dynamische structuur wordt door verschillende factoren bepaald. De opbouw van de oever is al divers, maar ook factoren als waterkwaliteit, stroomsnelheid, verschillende waterdiepte en verschillende substraten, zoals grind of zand, bepalen welke soorten hier kunnen leven. Naast dynamische factoren bepalen ook landschappelijke elementen, zoals uiterwaarden, wielen, nevengeulen en strangen, ooibossen en stroomdalgraslanden verschillen in biodiversiteitwaarde. Het rivierengebied is mede door deze afwisseling en dynamiek internationaal en nationaal van groot belang als leefgebied voor trekvogels, vissen, libellen, kokerjuffers, steenvliegen en haften. De belangrijkste faunasoorten die voor rivieren zijn aangewezen zijn: rivierrombout, bataafse stroommossel, platte zwanenmossel, bever, barbeel, kopvoorn, rivierdonderpad, meerval, riviergrondel, sneep, winde, rivierprik, zeeprik en aal. Vooral voor trekvissen is het internationale belang groot. De trekvissen elft, fint, houting, steur, zalm komen in Nederland vrijwel niet meer voor. Slechts enkele waterplanten komen voor in de rivier zelf; rivierfonteinkruid, doorgroeid fonteinkruid (nu alleen kleine rivieren) en vlottende waterranonkel in de Grensmaas. (Bron: Bij12; https://www.bij12.nl/onderwerpen/natuur-en-landschap/indexnatuur-en-landschap/de-index-natuur-en-landschap/natuurtypen/n02-rivieren/n02-01-rivieren/). 
In diepe plassen spelen zoö- en fytoplankton een centrale rol in de waterkwaliteit en zijn direct bepalend voor de helderheid van het water. Algen staan aan de basis van het voedselweb en hun groei wordt bepaald door nutriënten, temperatuur en licht. Anderzijds stuurt het fytoplankton de accumulatie van zuurstof. Fytoplankton wordt doorgaans gekwalificeerd op grond van het relatieve voorkomen van groenalgen, diatomeeën en blauwalgen. Het seizoen, daglengte, tijdstip, maar ook pH, voedselaanbod bepalen de diversiteit en abundantie van fyto- en zoöplankton, die weer een weerslag hebben op de aanwezige flora en fauna (Stowa, 2010).

De macrofauna van de diepe delen is soortenarm door het gebrek aan zuurstof (met name in de zomer) in de meeste diepe plassen. Sommige soorten vedermuggen en wormen zijn aangepast aan dit milieu. Ook komen er relatief minder vissen voor in diepe plassen dan in ondiepe wateren door het 'ontbreken' van de bodem in een groot deel van de plas. Daarbij komt dat door de nutriëntenval de trofiegraad van het water lager is. Toch zijn er enkele visgemeenschappen van diepe wateren die afhankelijk zijn van de trofische status, het voorkomen van waterplanten en de zichtdiepte: baarsblankvoorn (helder water), blankvoorn-brasem, brasem-snoekbaars (vooral troebel water). Nieuwe diepe plassen als gevolg van delfstofwinning hebben tegenwoordig meer ondiepe (oever)zones. Deze zijn gunstig voor de aquatische vegetatie, bieden meer paai- en opgroeigebied voor vissen en leefgebied voor macrofauna. De verhouding diep:ondiep bepaalt voor een belangrijk deel de ontwikkeling van biodiversiteit (Ostë et al. 2010).

\section{Ecologische zones van diepe plassen}

Een vanuit de ecologie vaak gehanteerde zonering is de verdeling van een plas in littoraal, profundaal en pelagiaal (Figuur 1). Deze zonering is afhankelijk van de ligging van de zogenoemde eufotische zone, de diepte waarop nog één procent van het zonlicht doordringt, en van de bodem.

De littorale zone is de belangrijkste voor de ontwikkeling van planten, insecten en vissen. Hier profiteren de soorten van zonlicht en komt voldoende licht op de bodem voor groei van ondergedoken waterplanten. In de pelagische zone komt het zonlicht niet bij de bodem en neemt het leven af naarmate diepte (profundale zone) wordt bereikt.

\section{ZONES IN STRATIFICERENDE DIEPE MEREN EN PLASSEN}

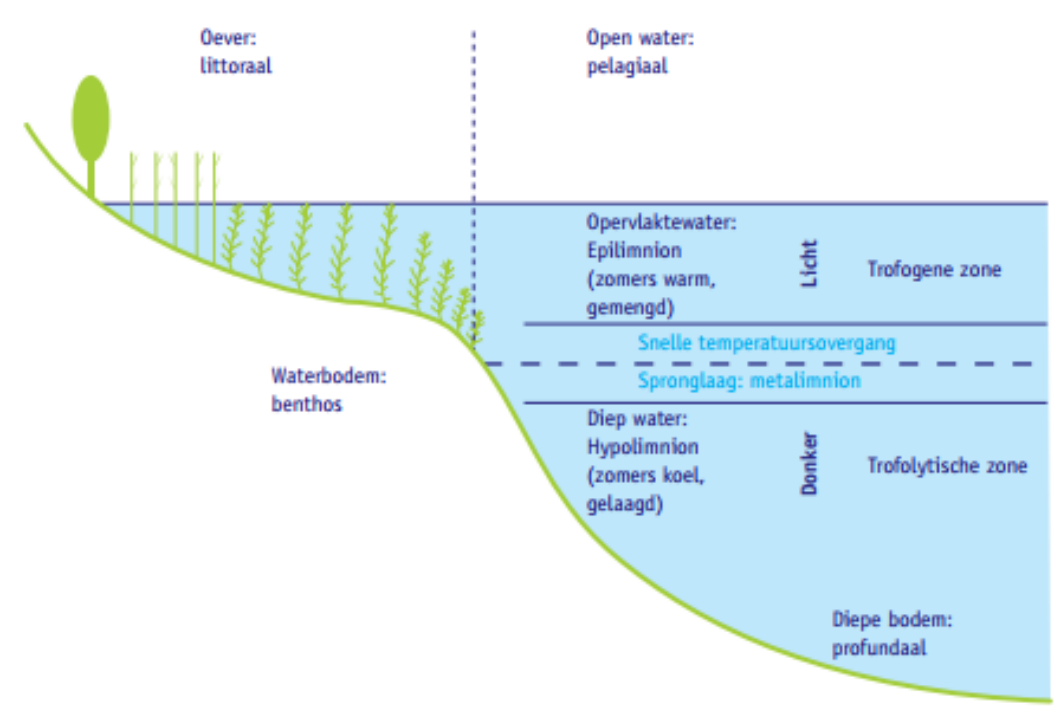

Figuur 1 Overzicht van de oeverzone langs een diepe plas (Bron: Ostë et al. 2010).

Inrichting, gebruik en beheer spelen een rol bij de risico's voor verontreinigingen. Zonder vegetatiebeheer zal de oeverzone verlanden, wat mogelijk risico's geeft op het vrijkomen van eventuele verontreinigingen (De Lange et al. 2015). Het aanbrengen van ondiepe zones betekent een vergroting van de erosiezone. Daarbij kan golfslag een effect hebben op de ontwikkeling van de vegetatie. De windrichting ten opzichte waarvan deze zone wordt aangelegd of het vormen van eilandjes voor deze zone zijn van invloed op de ontwikkeling van de biodiversiteit. (Van der Linden, 2007). 


\subsection{Bepalen van biodiversiteitwaarde}

Het zou makkelijk zijn als er een universele en eenduidige methode was om een biodiversiteitwaarde te berekenen. Helaas, biodiversiteit laat zich lastig berekenen, omdat deze overal anders is en sterk afhankelijk is van externe omstandigheden die invloed hebben op:

- de diversiteit aan soorten;

- de genetische variatie binnen de soorten;

- de diversiteit aan habitat en ecosystemen;

- en de relatie tussen deze aspecten.

Het interprovinciaal orgaan BIJ12 geeft uitgangspunten voor de voorwaarden waar structuur en variatie in het rivierengebied aan moeten voldoen, willen ze bijdragen aan de instandhouding van de karakteristieke soorten van rivieren. Met 16 aangeduide structuurelementen en een lijst van ruim 70 doelsoorten van planten vissen en libellen kan een kwaliteitsbepaling worden gedaan. Het betreffen hier overigens alleen soorten van natte en vochtige milieus:

- Goed: indien 12 of meer kwalificerende structuurelementen aanwezig zijn

- Matig: indien 8 of meer kwalificerende structuurelementen aanwezig zijn

- Slecht: indien <8 kwalificerende structuurelementen aanwezig zijn

En:

- Goed: indien meer dan 10 kwalificerende plantensoorten, meer dan 5 kwalificerende vissoorten en meer dan 2 kwalificerende libellen verspreid voorkomen

- Matig: indien meer dan 7 kwalificerende plantensoorten, meer dan 3 kwalificerende vissoorten en meer dan 1 kwaliteitssoort libellen verspreid voorkomen

- Slecht: indien niet aan de criteria voor de klasse matig wordt voldaan

Deze kwaliteitstoets wordt aangevuld met voorwaarden voor milieu- en watercondities, zoals hydrologie, chemie en waterdoorzichtbaarheid. Ook de ruimtelijke condities (bijvoorbeeld verbonden met zee) en de monitoring worden toegevoegd als kwaliteitsfactor.

Het bepalen van de biodiversiteit - en impliciet de natuurkwaliteit - is maatwerk en per locatie verschillend. Het voorkomen en overleven van soorten in een gebied is afhankelijk van verschillende factoren en condities. Tabel 1 geeft een overzicht van de belangrijkste factoren die invloed hebben op de natuurkwaliteit bij een winlocatie (Vliegenthart, 2011).

Tabel 1 Belangrijkste factoren die invloed hebben op de natuurkwaliteit van winlocaties.

\begin{tabular}{|c|c|c|}
\hline Invloed van & Factor & Eenheid \\
\hline Ligging in het landschap & - Afstand tot bronpopulaties & $\begin{array}{l}\text { - Rode Lijst-soorten } \\
\text { - Indicatorsoorten }\end{array}$ \\
\hline Beheer & $\begin{array}{l}\text { - Maaibeheer } \\
\text { - Snoeien } \\
\text { - Schonen } \\
\text { - Begrazing }\end{array}$ & $\begin{array}{l}\text { - Type grasland } \\
\text { - Houtwallen, struwelen } \\
\text { - Moeras, ven, plas } \\
\text { - Opslag en open plekken }\end{array}$ \\
\hline
\end{tabular}

Bij de oplevering van een winlocatie met een natuurdoelstelling worden vaak de oevers afgevlakt en ondiepe delen aangebracht. De indeling van de oever bestaat in gunstige gevallen uit een gevarieerde structuur van grasland, struweel of houtwallen. Samenstelling en type bodem hebben een uitwerking op de vegetatie en daarmee op de biodiversiteit. Zandgronden zijn armer en hebben een andere soortsamenstelling dan rivierkleigronden.

De grote plassen die meestal na ontgronden ontstaan, worden vaak in verbinding gebracht met bestaande wateren. Hierdoor komt vaak verrijkt gebiedsvreemd water in het gebied, wat eutrofiëring 
tot gevolg kan hebben. De aanwezige sloten kunnen de directe omgeving ontwateren, waardoor de kwaliteit van graslanden achteruitgaat.

Winlocaties liggen vaak in intensieve landbouwgebieden. De stroming van het grondwater is daarom zeer belangrijk. Deze zorgt voor de aan- en afvoer van meststoffen. Winlocaties met een buffer om het gebied zullen een hogere natuurwaarde hebben dan winlocaties die direct aan landbouwpercelen grenzen.

Het beheer van een winlocatie is essentieel voor de ontwikkeling en kwaliteit van de natuur. Structuur en variatie kunnen met goed gefaseerd beheer worden behouden; dit resulteert altijd in een hogere biodiversiteit. Het inzetten van grazers remt de natuurlijke successie en kan meer variatie in bodemstructuur opleveren.

Langs de rivieren ontstaan natuurlijke ooibossen. Deze kunnen bij hoogwater een stagnerende functie hebben waardoor veel zwerfvuil in het gebied achterblijft. Dit heeft uiteindelijk als resultaat dat er lokale vervuiling optreedt en vergroot bovendien het gezondheidsrisico voor de aanwezige dieren.

\subsection{Nieuwe natuurwaarden}

Ontgrondingen in het kader van zand- en grindwinning zijn anno 2018 niet meer op te voeren als primaire winningen. Deze activiteiten moeten te allen tijden zijn gekoppeld aan natuurontwikkeling, recreatie, wonen aan het water of rivierverruiming. Ontgrondingen hebben een grote impact op het landschap, maar kunnen bij oplevering ook meer natuurwaarde opleveren (Bak, 2012). Hierdoor ontstaat soms nieuwe natuur op plaatsen waar het anders niet zou zijn ontstaan. De ontgrondingsindustrie fungeert tegenwoordig steeds vaker als financiële motor voor lokale natuurontwikkeling, die nauw wordt afgestemd met terreinbeherende organisaties (TBO), omwonenden, boeren en ecologen.

Mooie voorbeelden van inmiddels gevestigde natuurgebieden die door vroegere ontgrondingen zijn ontstaan, zijn de Blauwe Kamer ten westen van Wageningen (tichelgaten) en de Millingerwaard ten oosten van Nijmegen. De Grensmaas bij Stein is een recenter voorbeeld van een combinatie van rivierverruiming en ontgronding, waarbij de doelstelling duidelijk gerelateerd was aan rivierverruiming en natuurontwikkeling.

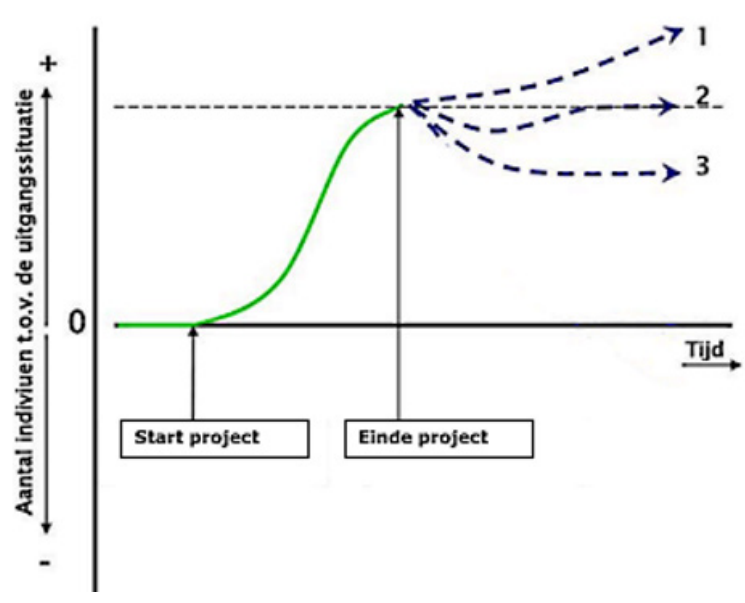

Figuur 2 Het verloop van verschillende scenario's voor de ontwikkeling van biodiversiteit na oplevering van delfstofwinningprojecten.

De natuurwaarden bij ontgrondingen ontstaan vooral doordat de voedselrijke bouwvoor wordt verwijderd en hierdoor schrale, voedselarme omstandigheden ontstaan waar zich weer nieuwe natuur ontwikkelt. Bij zandwinplassen zijn vaak in de beginfase soorten te vinden die thuishoren in pioniersystemen (zoals kleine plevier en rugstreeppad) die door latere successie overgaan naar ooibos of uiterwaarden. De ontwikkeling van nieuwe natuur begint al tijdens de eerste graafwerkzaamheden. In de eerste fase kenmerkt nieuwe natuur zich als tijdelijke natuur (Linnartz, 2006). De waarde van de afgravingen wordt ook bepaald door de ligging van het gebied. Zandwinplassen liggen vaak in 
intensieve agrarische gebieden en bieden een andere structuur en habitat in de omgeving. Oevers raken begroeid en meestal ontstaan er nieuwe wateren die allerlei dieren (voornamelijk vogels) aantrekken. Daarmee hebben afgravingen in agrarisch gebied meteen al een hogere natuurwaarde dan de directe omgeving (Goutbeek en Zekhuis, 2005). De aanwezigheid van bossen, beken, rivieren, meren en natuurlijke hoog- of laagveengebieden heeft een effect op de biodiversiteit bij een winlocatie. Bij grotere afstanden tot de winlocatie wordt de kans op kolonisatie van soorten kleiner (Bos et al. 2006). Dit geldt in het bijzonder voor soorten van drogere milieus, zoals stroomdalgraslanden. In nattere milieus speelt het probleem minder, omdat (zaden van) soorten zich via het water makkelijker kunnen verspreiden.

Bij nieuwe natuurontwikkeling kunnen verschillende scenario's volgen op de ontwikkeling van de biodiversiteit (de scenario's komen overeen met Figuur 2). De ontwikkeling van biodiversiteit kan:

1. Doorgroeien, omdat de populatie is verstevigd (aantal) en/of er meer genetische diversiteit in is gekomen (kwaliteit). Het nieuwe natuurgebied is een verspreidingskern geworden van waaruit nieuwe natuurgebieden worden gekoloniseerd. In dat geval zijn vaak kensoorten van het rivierengebied (bijhorende natuurdoeltypen) aanwezig.

2. Even inzakken, maar daarna kunnen de betreffende soorten/individuen zich vestigen. Deze fase is nog in ontwikkeling, zogenaamde successie waarbij kensoorten zich nog niet hebben gevestigd.

3. Definitief inzakken, maar wel op een hoger niveau blijven dan in de aanvangssituatie. Dit scenario is grotendeels afhankelijk van beheer en de invloed van de rivier. In deze fase is vooral sprake van jonge natuur en pionierstadia.

\subsection{Biodiversiteit meten}

Momenteel zijn er geen eenduidige tools om de biodiversiteit te meten. Toch zijn er tools te vinden die uitspraken doen over de biodiversiteit, maar deze zijn vaak beperkt, omdat biodiversiteit een complexiteit kent van soorten, ecosystemen en genetische variatie en tegelijkertijd sterk afhankelijk is van vele externe factoren. Afhankelijk van de plaats waar biodiversiteit moet worden bepaald, kan vanuit verschillende perspectieven worden onderzocht en dan nog is het lastig bepalen welke natuurwaarde hoger is. Een van de acceptabele vergelijkingen om toch biodiversiteit enigszins inzichtelijk te maken, is het bepalen van verschillen in soorten voor en na ingrepen in het landschap. Deze methode gaat goed op voor de ontgrondingsindustrie, omdat doorgaans landbouwgronden een heel andere bestemming krijgen. Binnen natuurgebieden blijft dit een speculatieve methode, omdat de weging van soorten niet eenduidig is. Zo is bijvoorbeeld een broedplaats voor een kleine plevier veelzeggend voor pioniersituaties, maar niet indicatief voor de kwaliteit van ooibos.

Sinds de start van dit millennium zijn er diverse studies verricht naar de effecten op biodiversiteit door middel van rivierverruiming. Prominente voorbeelden als Maas in beeld en het project Grensmaas geven inzicht in de rivierdynamiek. Hierbij worden vooral soorten genoemd die voorkomen in de studielocaties en wordt een relatie gelegd met de rivierdynamiek. Er wordt gesteld dat veel soorten een herstel laten zien in het project, maar dat de concentratie van deze soorten zich bevindt in de opengestelde extensieve recreatiegebieden. Dit is een gevolg van de verandering van het beheer en de omslag van landbouwgrond naar natuurlijke gronden. Ook het toelaten van meer rivierdynamiek met de bijhorende erosie en afzetprocessen en terugkeer van natuurlijke zand- en grindbodems heeft een bijdrage in de verandering van de soorten in het gebied (Peters \& Kurstjens, 2008).

In 2017 werden de uitkomsten van het onderzoek naar de effecten op de biodiversiteit van planten, vogels, zoogdieren, reptielen \& amfibieën, vissen, libellen en vlinders binnen het project 'Ruimte voor de Rivier' gepresenteerd. Dit onderzoek toont aan dat er veel soorten terugkeren in meer dan $75 \%$ van de uiterwaarden van de Rijn, Nederrijn, Waal en IJssel. Vooral mobiele groepen, zoals vogels en zoogdieren, namen toe. Maatregelen als nieuwe nevengeulen, natuurlijk beheer van graslanden en het toestaan van natuurlijke vegetatieontwikkeling leverden een significante verbetering in vergelijking met uiterwaarden waar deze maatregelen niet zijn toegepast. Het leefgebied voor planten, vlinders en libellen werd weliswaar groter, maar er werd (nog) geen toename van de doelsoorten vastgesteld. Voor sommige soorten zal gelden dat ze het gebied niet eenvoudig kunnen bereiken. Een belangrijke conclusie uit dit onderzoek is dan ook dat de ontwikkelingen in natuurherstel bij rivieren nog niet leiden tot het terugkeren van veel karakteristieke en indicatieve soorten van het rivierengebied. Om dit te bewerkstelligen, is een betere aansluiting nodig voor de specifieke habitat. (Straatsma et al. 2017). 


\section{Natuurpuntensysteem}

Het vergelijken van de aanwezigheid van soorten voor en na de ingreep wordt ook toegepast in het natuurpuntensysteem. Dit systeem is oorspronkelijk opgezet voor de bouwsector om op deze manier natuurinclusief bouwen te stimuleren en hiervan ook de resultaten zichtbaar te maken. Om de maatregelen die worden voorzien in het Deltaprogramma goed te kunnen beoordelen op biodiversiteitseffecten, heeft het Planbureau voor de Leefomgeving (PBL) een methodiekbeschrijving geleverd van waardering van natuur op basis van natuurpunten (land en water), inclusief voorbeeldtoepassingen. Daarbij is een zo goed mogelijke koppeling tot stand gebracht tussen de natuurpuntenaanpak en bestaande effectmodellen. Het PBL heeft dezelfde methodiek uitgewerkt voor aquatische natuur en voor de overgangen tussen terrestrisch en aquatisch. Hierdoor ontstaat een methode waarmee effecten van maatregelen boven en onder water integraal kunnen worden beschouwd (PBL, 2014). In de Algemene leidraad voor maatschappelijke kostenbatenanalyse (Romijn \& Renes, 2013) wordt de natuurpuntenmethodiek genoemd als systematiek waarmee op een gestructureerde en integrale manier de effecten van ingrepen op biodiversiteit kunnen worden geduid. Natuurpunten zijn een kwantitatieve aanduiding voor biodiversiteit. Het formaliseert de effecten op biodiversiteit als gevolg van een gehanteerde ingreep. Deze aanpak wordt ook toegepast voor bijvoorbeeld habitatbanking en natuurcompensatie. Natuurpunten worden uitgedrukt als het product van het oppervlak, de natuurkwaliteit en de weegfactor van elk van de onderscheiden natuurtypen (Jaspers et al. 2016):

Natuurpunten $=$ natuurkwaliteit $x$ weegfactor $x$ oppervlakte.

\section{Natuurpunten als product van oppervlak, natuurkwaliteit en weegfactor}

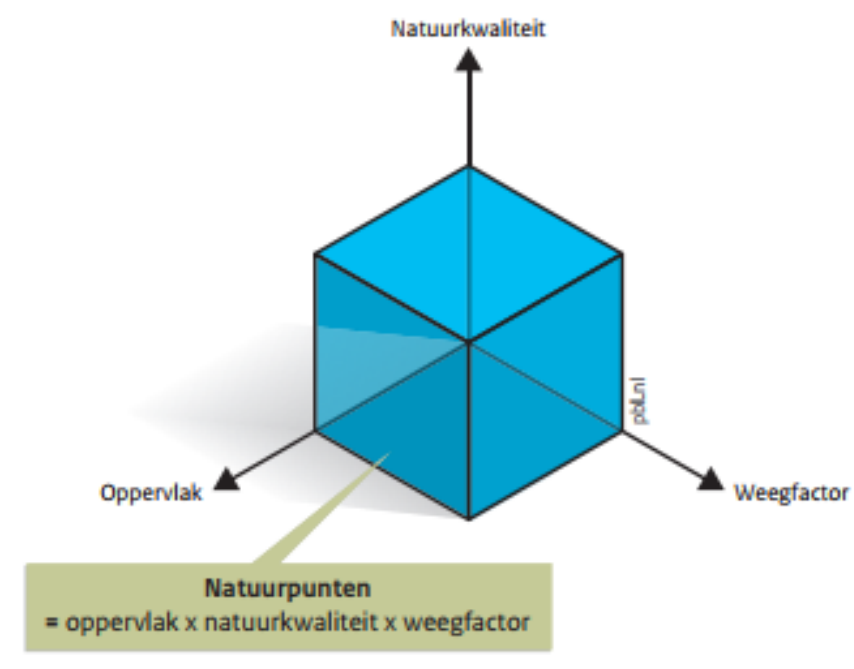

Figuur 3 Schematische weergave van het natuurpuntensysteem (Jaspers, 2016).

In $\S 3.2 .2$ wordt de toegepaste berekening nader uitgelegd.

Met Natuurpunten kunnen verschillende projecten worden vergeleken, mits een eenduidige aanpak in methode en gebiedsomgrenzing is gebruikt. De oppervlakte heeft een belangrijke functie in de vergelijkingen tussen projecten: hoe groter het oppervlak, des te groter de verandering in natuurpunten. Hierbij geldt dat kleine of sterk in areaal achteruit gaande natuurtypen vaak meer zeldzame en bedreigde soorten bevatten en daarmee een hogere weegfactor hebben. Of het natuurpuntensysteem ook bruikbaar is om de biodiversiteitswaarde voor de ontgrondingsindustrie te berekenen, is onderzocht door De Vlinderstichting (Van de Put, 2017) en wordt in dit rapport verder besproken. 


\section{$2.5 \quad$ Waterstandverlaging}

Door de klimaatverandering krijgen de Nederlandse rivieren te maken met grotere fluctuaties in de waterstanden. Recente (inter)nationale onderzoeken en klimaatscenario's wijzen uit dat de afvoer van regen- en smeltwater, met name van de Rijn, in de winter toeneemt. Op dit moment kan een hoeveelheid water van $15.000 \mathrm{~m}^{3} / \mathrm{s}$ bij Lobith veilig naar zee worden afgevoerd. Door de maatregelen van 'Ruimte voor de Rivier' gaat deze afvoercapaciteit met duizend kubieke meter per seconde omhoog, naar $16.000 \mathrm{~m}^{3} / \mathrm{s}$. Verwacht wordt dat in 2100 de hoeveelheid water door de Rijn richting Nederland gaat variëren van 17.000 tot $22.000 \mathrm{~m}^{3} / \mathrm{s}$ of meer. Op grond van deze inzichten over afvoertoename, aftoppen en het effect van Duitse maatregelen daarop, wordt in het Deltaprogramma aangenomen dat voor de langere termijn de maximale afvoer die Nederland kan bereiken met $2.000 \mathrm{~m}^{3} / \mathrm{s}$ zal kunnen toenemen tot $18.000 \mathrm{~m}^{3} / \mathrm{s}$ (Rijksoverheid, 2018 - Deltaprogramma Rivieren).

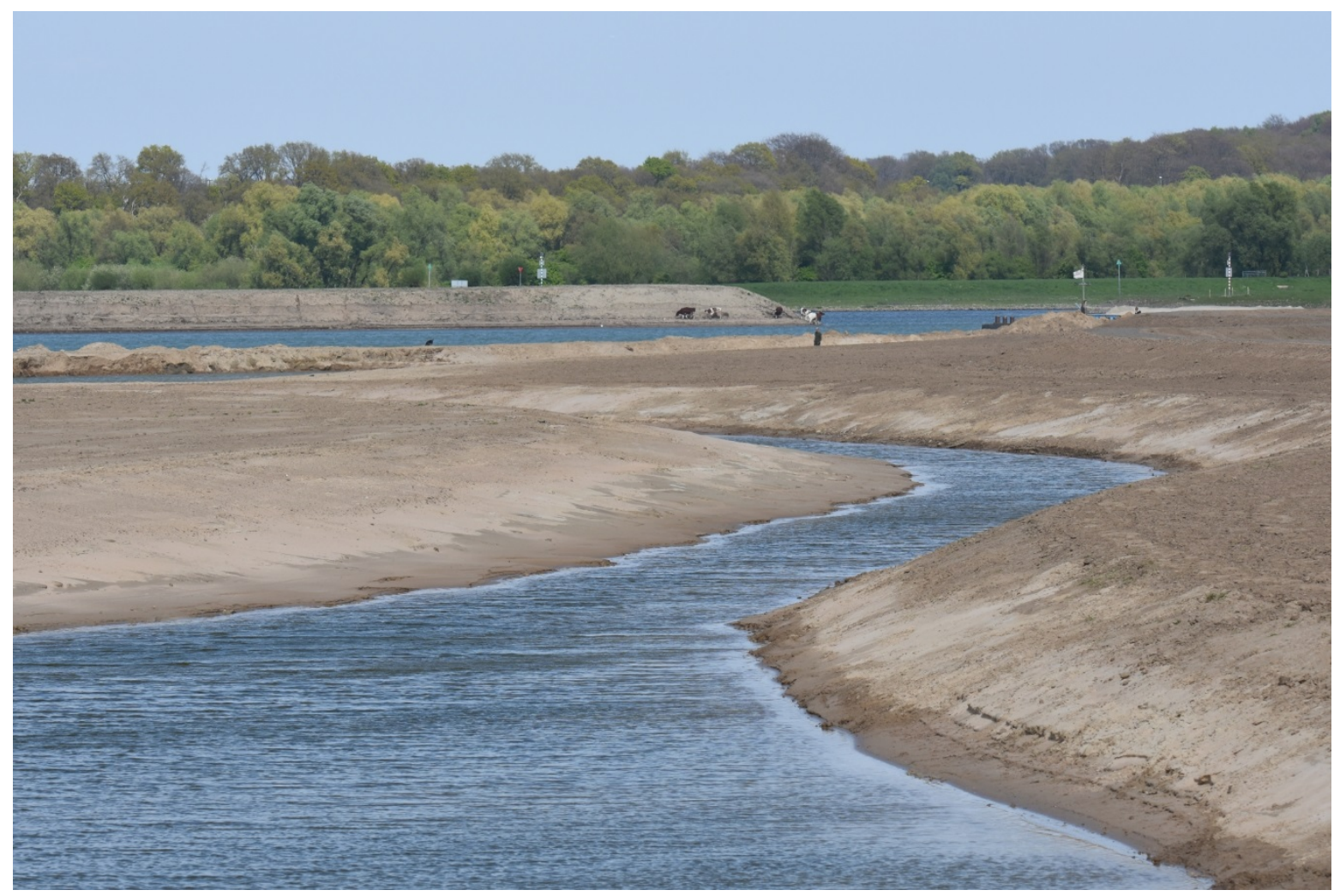

Foto 3 Hier komt nieuwe natuur in de Randwijkse uiterwaarden (Foto: Albert Vliegenthart).

Na de waterveiligheidsnormen voor de primaire waterkeringen uit 2014 zijn per 1 januari 2017 strengere normen opgelegd voor de meeste rivierdijken. De actuele faalkansen van deze dijken zijn veel groter dan de voorgestelde nieuwe veiligheidsnormen, hetgeen resulteert in een flinke veiligheidsopgave in het rivierengebied. In het Deltaprogramma Rivieren (DPR) zijn verschillende maatregelen en strategieën verkend om deze waterveiligheidsopgave op te lossen. In de voorkeurstrategie rivieren die in het kader van het Deltaprogramma is ontwikkeld, is gekozen voor een krachtig samenspel van dijkversterking en rivierverruiming.

Het is na de laatste dijkverzwaringen lastiger (soms onmogelijk) om deze verder te versterken, waardoor de focus is verschoven naar 'Ruimte voor de Rivier'. Hierbij wordt de afvoercapaciteit (en daarmee de veerkracht) van de rivier vergroot en worden robuuste en duurzamere effecten bereikt, zoals:

1. waterstandverlaging, het verminderen van de overstromingskansen;

2. ontlasten van dijkversterking en daarmee een kostenbesparing op benodigde dijkversterkingsmaatregelen (Van Vuren, 2015 \& 2017); 
3. directe meerwaarde voor een gebied; vooral bij goede combinatie met delfstofwinning, natuurontwikkeling, het verbeteren van ruimtelijke kwaliteit en het creëren van mogelijkheden voor recreatie en bedrijvigheid;

4. kansen voor natuurdoelen, zoals ontwikkeling van ooibos (Natura 2000) en rivierdynamiek (Kader Richtlijn Water).

Het vergroten van de retentie door het verlagen van uiterwaarden en het graven van nevengeulen wordt breed gedragen als mogelijkheid om de waterveiligheid te vergroten. Echter, de nevengeulen die volgens de principes van Levende Rivieren zijn aangelegd, leveren slechts een bescheiden bijdrage aan de waterstanddaling (orde 3-10 cm). Om meer effect te bereiken (orde 20-30 cm), zijn nevengeulen veel breder en dieper dan vanuit rivierecologisch oogpunt gewenst; de meerwaarde voor natuur is hierdoor klein. Waar de zand- en grindwinning wordt ingezet om de benodigde rivierkundige ruimte te realiseren, is de mate van vergraving vaak nog veel groter dan rivierecologisch optimaal is. Door het gedeeltelijk aanvullen van de diepe winningen met onvermarktbare grond kan daar alsnog ondiep water worden gerealiseerd (Beekers et al. 2017).

Het bepalen van de waterstandverlaging gebeurde voorheen op basis van een overschrijdingskans. De overschrijdingskans is de jaarlijkse kans dat het buitenwater nog hoger kan komen te staan dan een bepaalde waterstand. Die waterstand wordt de maatgevende hoogwaterstand (MHW) genoemd. Hierbij was het wenselijk om de gerealiseerde waterstandverlaging uit te drukken in centimeters. Echter is de norm aangepast naar een overstromingskans en wordt nu uitgedrukt in (een afname van) de veiligheidsnorm (nu gebaseerd op een overstromingskans van 1x per 1250 jaar). Een afname van de overstromingskans heeft vervolgens effect op de mate van dijkversterking en daarmee op de dijkversterkingskosten. Daarmee kan worden bepaald in hoeverre een maatregel kosteneffectief is in termen van een afname van de dijkversterkingskosten.

Desondanks is het nog altijd gebruikelijk om de waterstandverlaging in centimeters uit te drukken. Met deze methodiek is het echter lastig te bepalen wat nu het daadwerkelijke effect is, omdat deze verlaging afhankelijk is van onder andere de locatie (omvang project) en het debiet van de rivier. Figuur 4 toont dat de waterstandverlaging het grootst is op de plaats waar de ingreep plaatsvindt en logaritmisch afneemt over het riviertraject. Daarbij speelt ook dat de gerealiseerde waterstandverlaging kan worden beïnvloed indien rivierverruimingsprojecten dicht op elkaar binnen het riviertraject liggen.

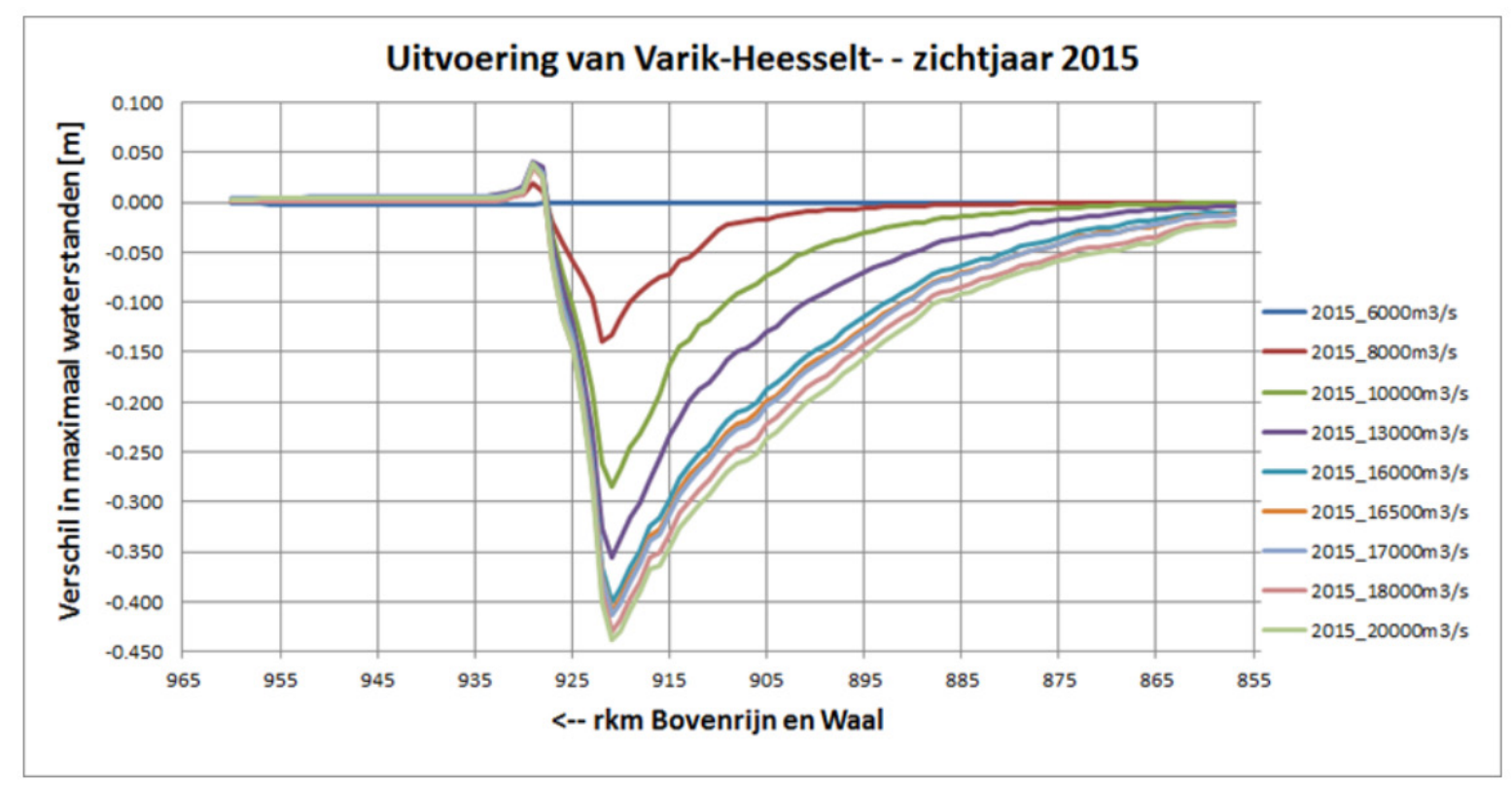

Figuur $4 \quad$ Voorbeeld van de waterstandverlaging bij Varik-Heeselt bij verschillende stroomsnelheden van de rivier (Bron: Van Vuren et al. 2015). 


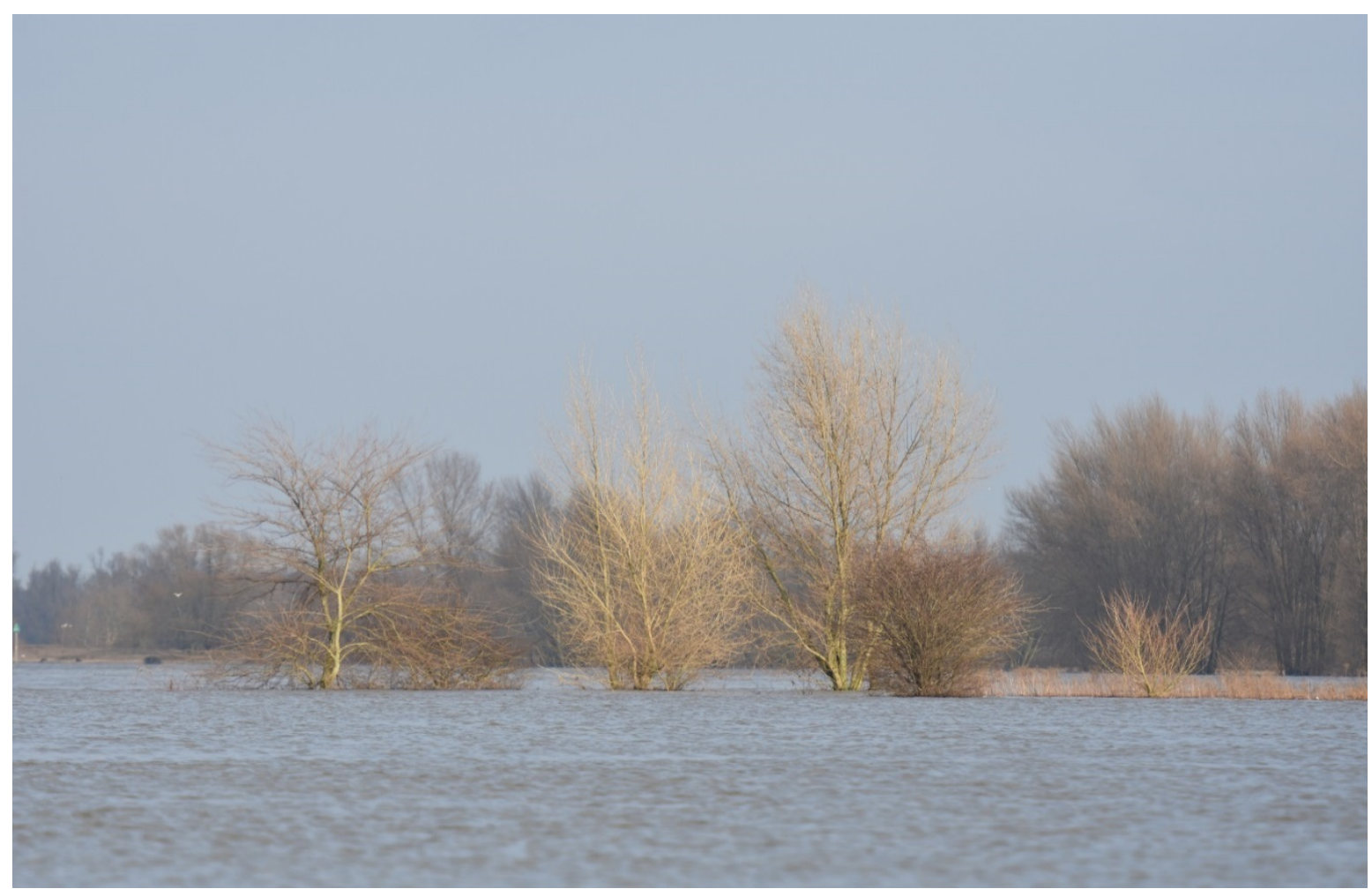

Foto 4

Hoog water in de Waal (Foto: Albert Vliegenthart). 


\section{$3 \quad$ Methode}

\subsection{Gebieden}

Voor de analyse of de biodiversiteit beïnvloed is door delfstofwinning heeft Cascade een voorselectie gemaakt van gebieden. Daarbij zijn de volgende criteria gebruikt:

- Ligging in de uiterwaarden

- Project geïnitieerd vanuit bedrijfsleven

- Bij voorkeur type grind of industriezandwinning (= hoofdproduct)

- Bij voorkeur combinatie van natuurontwikkeling, rivierverruiming en zand- of grindwinning

- Mix van reeds gerealiseerde projecten (= natuur ontwikkeld), in uitvoering zijnde projecten (= natuur in ontwikkeling), in voorbereiding (rivierverruiming en bestaande natuur)

Gebieden die nog in voorbereiding zijn, waren nog niet bruikbaar voor de analyse. Uiteindelijk zijn voor de analyse 24 gebieden gebruikt, zie Tabel 2.

Tabel $2 \quad$ Lijst van 24 gebieden die gebruikt zijn in de analyses.

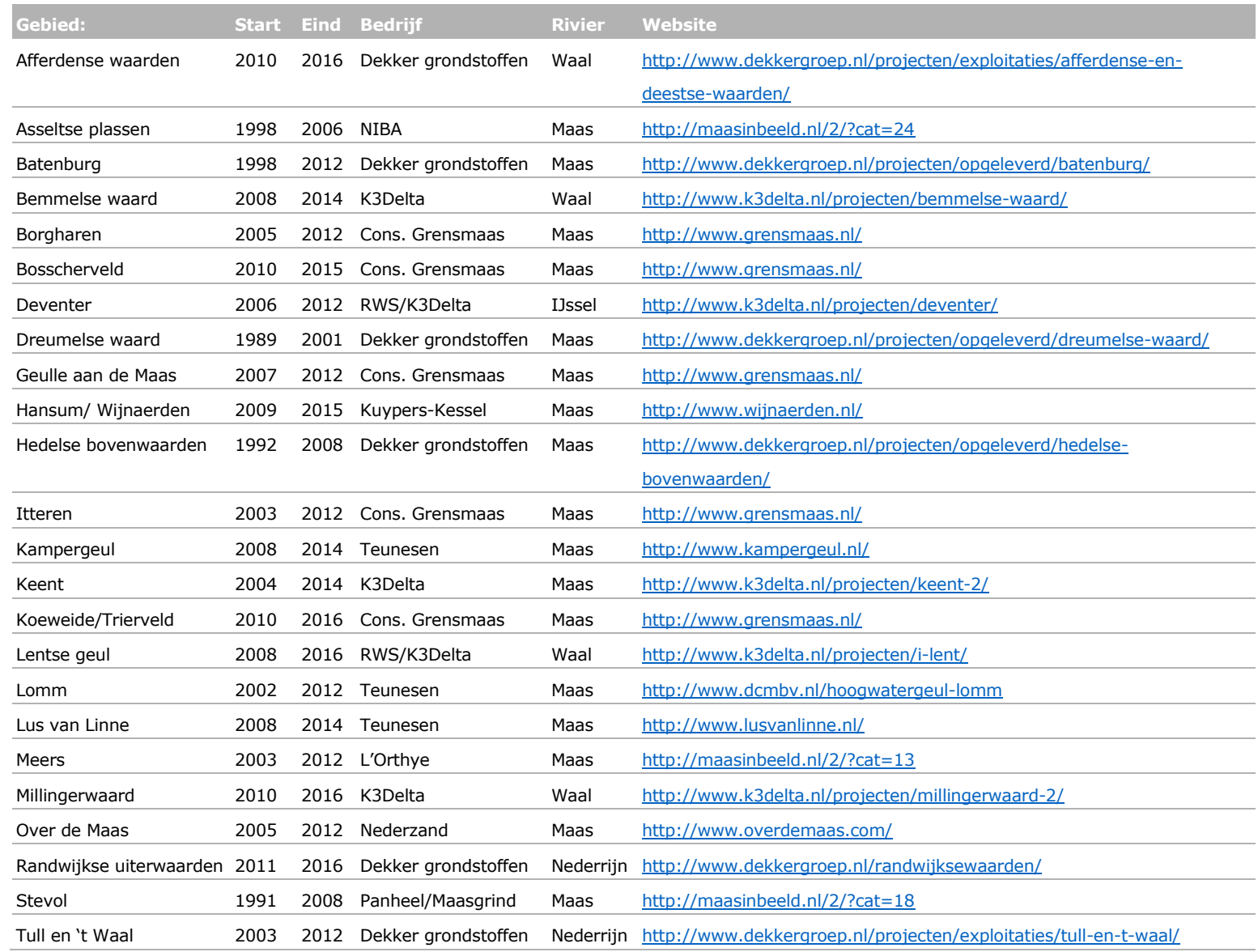

De ligging van de gebieden is weergegeven in Figuur 5 en 6. 


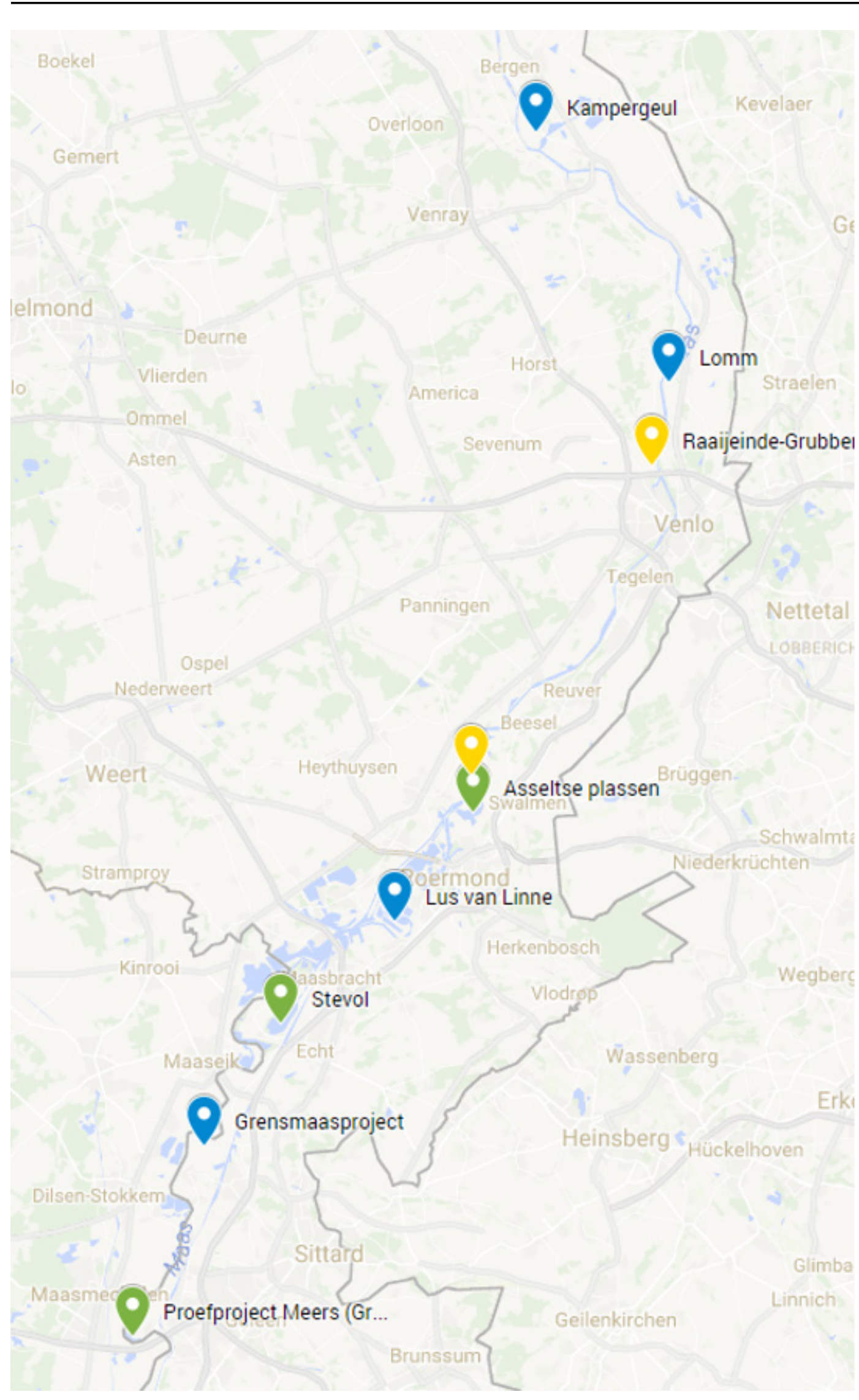

Figuur 5 Ligging van de zand-en grindwinningsgebieden langs de Maas. Groen = gereed, Blauw = in uitvoering, Geel = in voorbereiding. 


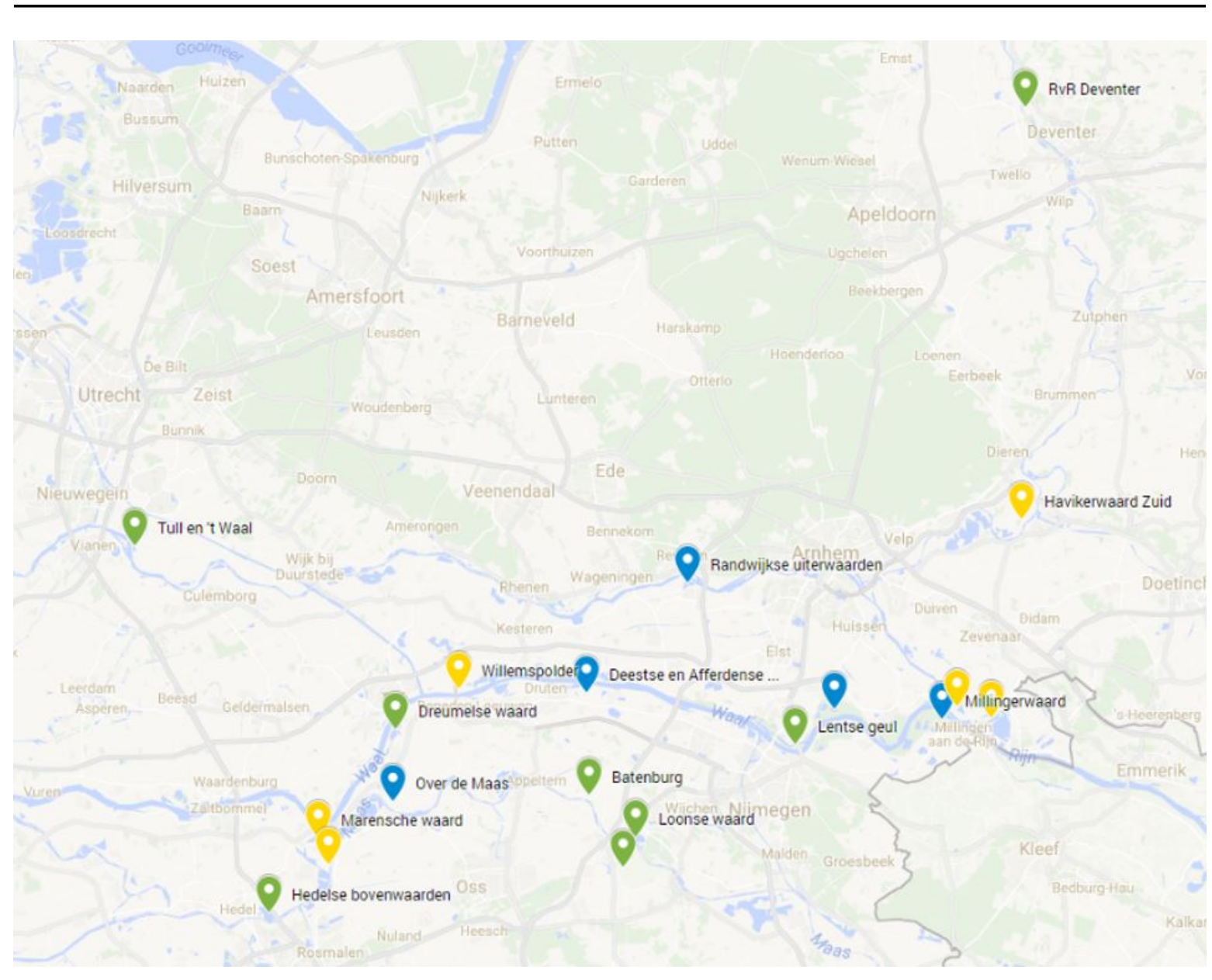

Figuur 6 Ligging van de zand- en grindwinningsgebieden langs de Waal, Rijn en IJssel. Groen = gereed, Blauw = in uitvoering, Geel = in voorbereiding.

\subsection{Biodiversiteit}

\subsubsection{NDFF en waarnemingsperioden}

Biodiversiteit is een complex begrip. Het gaat niet alleen om de diversiteit aan soorten in een landschap. Het is ook het verschillende habitat, de genetische interactie binnen de soorten en de relatie tussen de soorten en het landschap. Deze complexiteit heerst zowel boven als onder de grond en in de lucht en in het water. Een deel van deze complexe biodiversiteit is door ons onderzocht in dit project. Het betreft dan vooral de diversiteit aan soorten.

Om na te gaan hoe de biodiversiteit beïnvloed is door delfstofwinning, is een analyse gemaakt van de soorten die voor en na de zand- of grindwinning in een projectgebied aangetroffen zijn. Voor de soortgegevens is gebruikgemaakt van de Nationale Databank Flora en Fauna (NDFF). Omdat we een vergelijking maken van de situatie voor en na afloop van de winning, zijn voor de analyse alleen gebieden gebruikt waar de winning al minimaal 2 jaar afgesloten is. Dit betreft 24 gebieden. Standaard zijn perioden van 5 jaar voor en 5 jaar na de winning genomen. Indien de periode na de winning korter was dan 5 jaar, is een even grote periode voor de winning genomen. De volgende soortgroepen zijn gebruikt: dagvlinders, libellen, vaatplanten, vissen, vogels en zoogdieren. Per gebied is een shapefile gemaakt met een bufferzone van $500 \mathrm{~m}$ rondom het wingebied. Binnen die zone zijn alle gegevens van soorten waarvan de waarneming volledig binnen de buffer valt uit de NDFF gehaald. Voor vogels zijn de overvliegende exemplaren weggelaten, aangezien ze niet zeker binding met het gebied hebben. Daarna zijn voor alle soorten de waarnemingen vereenvoudigd tot aan- of afwezig in de perioden. Aantallen of hoe vaak een soort is waargenomen, zijn dus weggelaten. NDFF-gegevens worden verzameld door vrijwilligers en bestaan uit een verzameling van systematisch verzamelde gegevens (bijv. meetnetten) en losse waarnemingen (bijv. uit waarneming.nl). Omdat dit verschilt per gebied, maakt de vereenvoudiging de gebieden beter vergelijkbaar. 


\subsubsection{Berekening natuurwaarde via natuurpuntensysteem}

Voor het berekenen van de natuurkwaliteit van een gebied is er behoefte aan een uniforme, objectieve maat. Jaspers et al. (2016) hebben een aantal bestaande natuurwaarderingssystemen getest en een voorstel gedaan voor een geoptimaliseerd natuurpuntensysteem. Voor dit onderzoek met bijbehorende vraagstelling zijn wij nagegaan of deze methode bruikbaar zou kunnen zijn.

Het (door)ontwikkelde natuurpuntensysteem bestaat uit het volgende berekeningsprincipe:

\section{Natuurpunten $=$ kwaliteit $x$ weegfactor $x$ oppervlakte}

De berekening wordt uitgevoerd voor homogene gebiedseenheden, waaraan een natuurtype wordt toegekend op basis van de typologie van het Handboek Natuurdoeltypen. Aan deze natuurtypen zijn de referentielijsten van kenmerkende soorten gekoppeld. Per natuurtype-eenheid worden de berekeningsfactoren als volgt bepaald:

- Kwaliteit: percentage van het aantal referentielijstsoorten dat aanwezig is in de huidige situatie of in de toekomstige situatie verwacht, gemiddeld over minimaal drie kenmerkende soortengroepen.

- Weegfactor: factor die is gebaseerd of afgeleid van de door PBL bepaalde maatlat voor weging van natuurtypen op basis van (inter)nationale zeldzaamheid en trend van soorten. Bloemrijk grasland heeft bijvoorbeeld een hogere weegfactor dan wilgenstruweel, zie Tabel 3).

- Oppervlakte: gemeten of berekende oppervlakte van de natuurtype-eenheid in hectare. Ieder aanwezig natuurdoeltype (Bal et al. 2001) heeft zijn eigen referentielijst.

Het totaal aantal natuurpunten per project is een optelsom van de natuurpunten van de verschillende natuurtypen in de huidige of toekomstige situatie.

\section{Tabel 3 Weegfactoren van natuurtypen uit het rivierengebied.}

$\begin{array}{lrl}\text { Code } & \text { weegfactor } & \text { Natuurdoeltype } \\ 3.61 & 0.4 & \text { Ooibos } \\ 3.55 & 0.7 & \text { Wilgenstruweel } \\ 3.16 & 0.8 & \text { Dynamisch rivierbegeleidend water } \\ 3.66 & 0.9 & \text { Bos van voedselrijke, vochtige gronden } \\ 3.14 & 1.2 & \text { Gebufferde poel en wiel } \\ 3.53 & 1.2 & \text { Zoom, mantel en droog struweel van het rivieren- en zeekleigebied } \\ 3.49 & 1.3 & \text { Rivierduin en-strand } \\ 3.09 & 1.3 & \text { Snelstromende rivier en nevengeul } \\ 3.32 & 1.5 & \text { Nat, matig voedselrijk grasland } \\ 3.10 & 1.7 & \text { Langzaam stromende rivier en nevengeul } \\ 3.50 & 2.2 & \text { Akker van basenrijke gronden } \\ 3.24 & 2.2 & \text { Moeras } \\ 3.39 & 3.1 & \text { Bloemrijk grasland van het rivieren- en zeekleigebied }\end{array}$

Het bovenstaande natuurpuntensysteem is in eerste instantie gericht op toepassing voor natuurinclusief bouwen. Er zit ook een module in om de kwaliteit van een toekomstige situatie te bepalen op basis van een expertbeoordeling. Voor het doel in dit project, het vergelijken van de natuurkwaliteit voor en na de winning zijn daadwerkelijk aangetroffen soorten gebruikt en is een expertbeoordeling niet nodig. Ook is het vaststellen van exacte oppervlakten van natuurtypen niet mogelijk door het ontbreken van kaarten en recente luchtfoto's. Daarom is voor dit project gewerkt met een vereenvoudigde versie van bovenstaand natuurpuntensysteem. Deze methode was als volgt:

1. Op basis van kaarten en luchtfoto's is van elk gebied bepaald welke natuurtypen er voorkomen (bijvoorbeeld bloemrijk grasland, langzaam stromende nevengeul, gebufferde poel).

2. Van elk natuurtype zijn de aangetroffen soorten (uit de NDFF) van de zes soortgroepen vergeleken met lijsten met referentiesoorten van dat type. Dit is gedaan voor de periode voor de winning en de (even lange) periode na de winning. Referentiesoorten zijn karakteristieke (doel)soorten behorend bij dat type. Hoe meer van deze soorten aanwezig zijn, hoe beter ontwikkeld het type. 
Voor elk van de soortgroepen is het aandeel (fractie) van het aantal aanwezige soorten van de totale referentielijst berekend.

3. Voor elke soortgroep en voor elk natuurtype wordt de fractie vermenigvuldigd met de weegfactor van dat natuurtype. Daarna worden getallen van de soortgroepen bij elkaar opgeteld. Op deze manier ontstaat een natuurscore voor elk gebied: één voor de winning en één na de winning.

\section{Deelonderzoek Hedelse Bovenwaard}

In deze studie is een deelonderzoek uitgevoerd voor de Hedelse Bovenwaard om te zien of het natuurpuntensysteem een goede berekening geeft over de biodiversiteitswaarde en of deze ook uniform inzetbaar is. De Bijlandse Waard, een uiterwaard van de Oude Waal en nu het Bijlands kanaal, is als referentie gebied gekozen, omdat hier dezelfde natuurdoeltypen en een overeenkomstig habitat aanwezig zijn.

Een beknopte inventarisatie in de periode mei-juni 2017 en gegevens uit de Nationale Databank Flora en Fauna (NDFF) (gevalideerde waarnemingen) werden van de periode januari 1999 tot juni 2017 soorten vastgesteld van de Hedelse Bovenwaard en de Bijland. Van beide gebieden is de huidige natuurkwaliteit berekend aan de hand van verspreidingsgegevens van planten, vlinders, libellen en vogels. De kensoorten zijn per habitattype in kaart gebracht. In het onderzoek zijn alleen terrestrische delen en oevers onderzocht. Grote en diepe wateren werden bij de berekening buiten beschouwing gelaten.

\subsubsection{Grootte van de gebieden, waarnemerseffect}

Bij het gebruikmaken van gegevens verzameld door vrijwilligers speelt het zogenaamde waarnemerseffect een rol. Vrijwilligers willen graag bijzondere soorten waarnemen en lopen dus vaker in natuurgebieden dan bijvoorbeeld in maisakkers. Ook is de mogelijkheid om gegevens digitaal in de NDFF te zetten de laatste jaren veel eenvoudiger geworden door mobiele apps. Het aantal waarnemingen dat jaarlijks in de NDFF stroomt, is daardoor momenteel veel groter dan 10-15 jaar geleden. Uit de periode na de winning zal naar verwachting in de meeste gebieden het aantal waarnemingen groter zijn dan uit de periode van voor de winning. De kans dat een soort is aangetroffen, wordt daardoor ook groter. Om na te gaan of dit de resultaten sterk beïnvloedt, is het verschil tussen het aantal waarnemingen voor en na de winning uitgezet tegen de berekende natuurwaarde. Ook de grootte van een gebied kan een rol spelen. Hoe groter een gebied, hoe groter de kans dat een bijzondere soort is waargenomen. Ook hiervan is nagegaan in hoeverre dit invloed heeft op de resultaten.

\subsubsection{Welke soorten verdwijnen of verschijnen?}

Om de resultaten ecologisch te kunnen duiden, is een nadere analyse gemaakt van de soorten. Allereerst is een check op alle gegevens gemaakt. Sommige soorten zijn bijvoorbeeld niet tot op soortniveau gedetermineerd. Als op basis van de andere gegevens kon worden beredeneerd welke soort het vrijwel zeker geweest moest zijn, is dit gecorrigeerd; in alle andere gevallen zijn dit soort waarnemingen verwijderd uit de dataset. Vervolgens is elke soort die in een van de 24 gebieden is waargenomen per gebied ingedeeld in een van de volgende categorieën

1. Soort was voor de winning aanwezig en is ook na de winning waargenomen.

2. Soort was voor de winning aanwezig, maar is na de winning niet meer waargenomen.

3. Soort was voor de winning niet aanwezig en is na de winning wel waargenomen.

4. Soort was zowel voor als na de winning niet aanwezig (maar minimaal wel $1 \mathrm{x}$ in een van de andere gebieden).

Elke soort is dus $24 \mathrm{x}$ ingedeeld in een van deze categorieën. Daarna zijn de soorten op basis van het verschil in aantal keer in categorie 2 (voor wel, na niet) en 3 (voor niet, na wel) gesorteerd. Bovenaan staan dan de soorten die vaker 'verdwenen' zijn en onderaan de soorten die vaker 'verschenen' zijn. Op basis van de ecologie van de soorten valt vervolgens wat te zeggen over de gemiddelde richting waarin de 24 gebieden zich ontwikkelen.

Doelsoorten voor het rivierengebied zijn apart onderscheiden.

1. op basis van de Index Natuur en Landschap (zie website https://www.bij12.nl/onderwerpen/natuur-en-landschap/index-natuur-en-landschap/de-index- 
natuur-en-landschap/natuurtypen/n02-rivieren/n02-01-rivieren/). Dit betreft soorten van natte natuur behorend bij de vaatplanten, libellen en vissen

2. Stroomdalplanten, soorten op droge standplaats zoals benoemd in Sykora \& Rotthier (2014).

3. Doelsoorten van Vochtige Alluviale Bossen (H91E0) zoals beschreven in de profieldocumenten Natura 2000

(https://www.synbiosys.alterra.nl/natura2000/gebiedendatabase.aspx?subj=habtypen\&groep=9\&i $d=91 E 0)$

\subsection{Waterstandverlaging}

Voor dit project heeft Ron Agtersloot, deskundige op het gebied van rivierdynamiek, achtergrondinformatie aangeleverd die bruikbaar is in dit onderzoek. Daarnaast zijn gegevens over de waterstandverlaging opgevraagd bij de betrokken bedrijven.

Een goede interpretatie over de bijdrage van de zand- en grindwinningsindustrie in vergelijking met andere projecten in het kader van 'Ruimte voor de Rivier' bleek uiteindelijk niet mogelijk, omdat er geen eenduidige methodiek is om de effecten op waterstandverlaging over meerdere projecten te meten. Afhankelijk van de locatie kunnen deze effecten worden beïnvloed door rivierverruimingsprojecten die op korte afstand van elkaar liggen. Een voorbeeld hiervan is het Grensmaas-project. Het optellen van de gerealiseerde centimeters waterstandverlaging per project geeft een globaal beeld, maar kan niet als een vaste waarde worden berekend.

\subsection{Interviews}

Om de overeenkomsten tussen de verschillende bedrijven te onderzoeken en te bepalen welke factoren de industrie met elkaar verbindt, zijn interviews gehouden met ontgronders die projecten hebben langs de Maas, Waal en Rijn. Voor de interviews zijn bezoeken afgelegd, waarbij gesprekken zijn gehouden met de projectleiders en/of directieleden. De interviews zijn afgenomen door middel van open gesprekken waarin een aantal vragen op het gebied van biodiversiteit, waterstandverlaging en communicatie zijn opgenomen. Vooraf is een aantal vragen opgesteld die in alle interviews onderwerp van gesprek zijn geweest. Als bepaalde vragen niet relevant waren of in het gesprek niet aan de orde kwamen, is de informatie achteraf opgevraagd bij de bedrijven. Om dit gestructureerd te doen, is een speciaal Google-formulier ontwikkeld met 14 meer 'technische' vragen, zoals het aantal hectares winst aan natuur of $\mathrm{cm}$ waterstandverlaging.

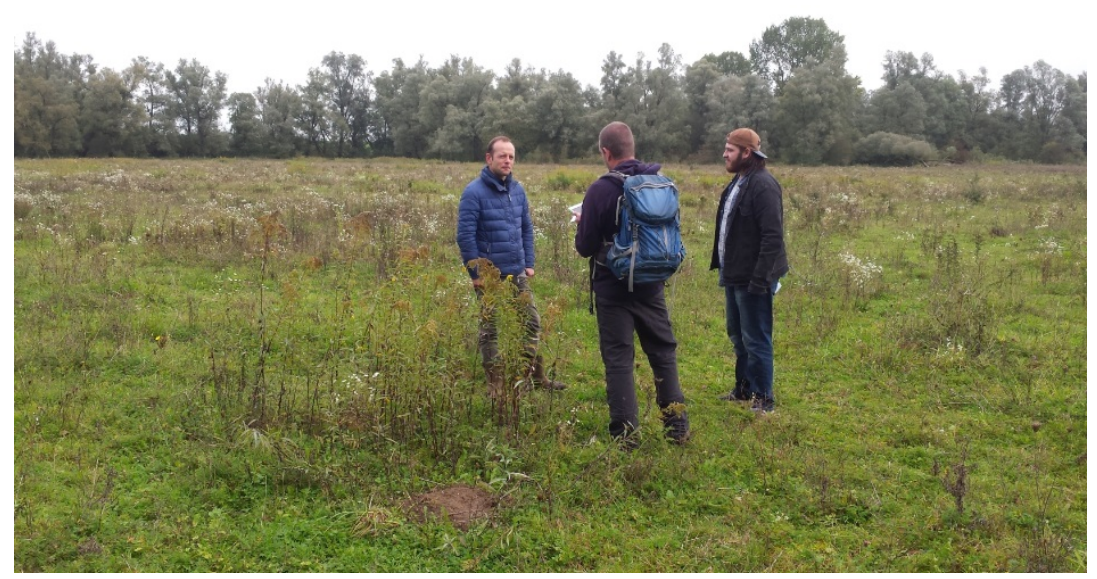

Foto 5

Lobberdense waard (Foto: Friso van der Zee). 


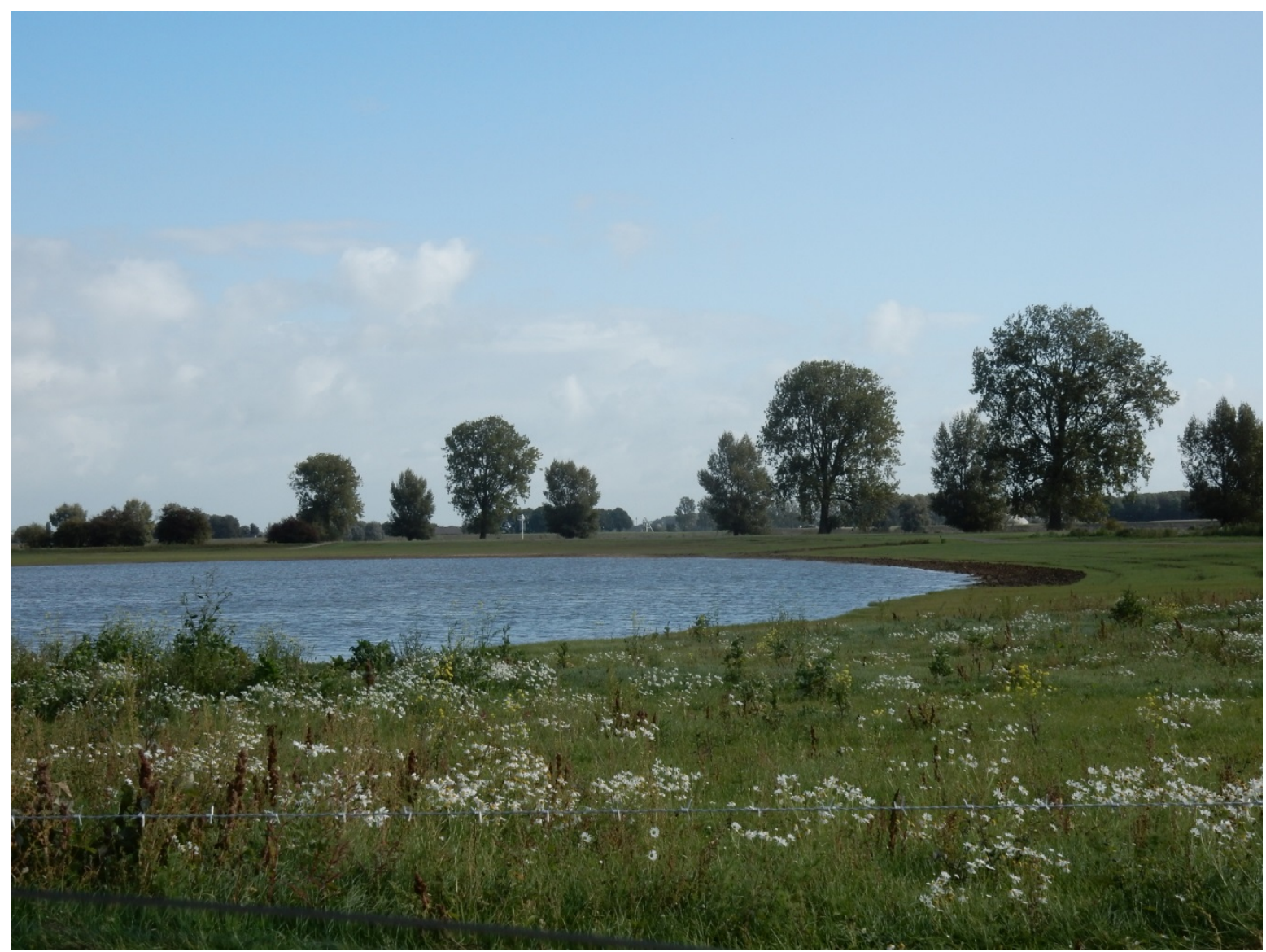

Foto 6 Project 'Over de Maas'. Schaatsplas gerealiseerd op verzoek van omwonenden (Foto: Albert Vliegenthart). 


\section{Resultaten}

\subsection{Biodiversiteit}

\subsubsection{Natuurwaarden algemeen}

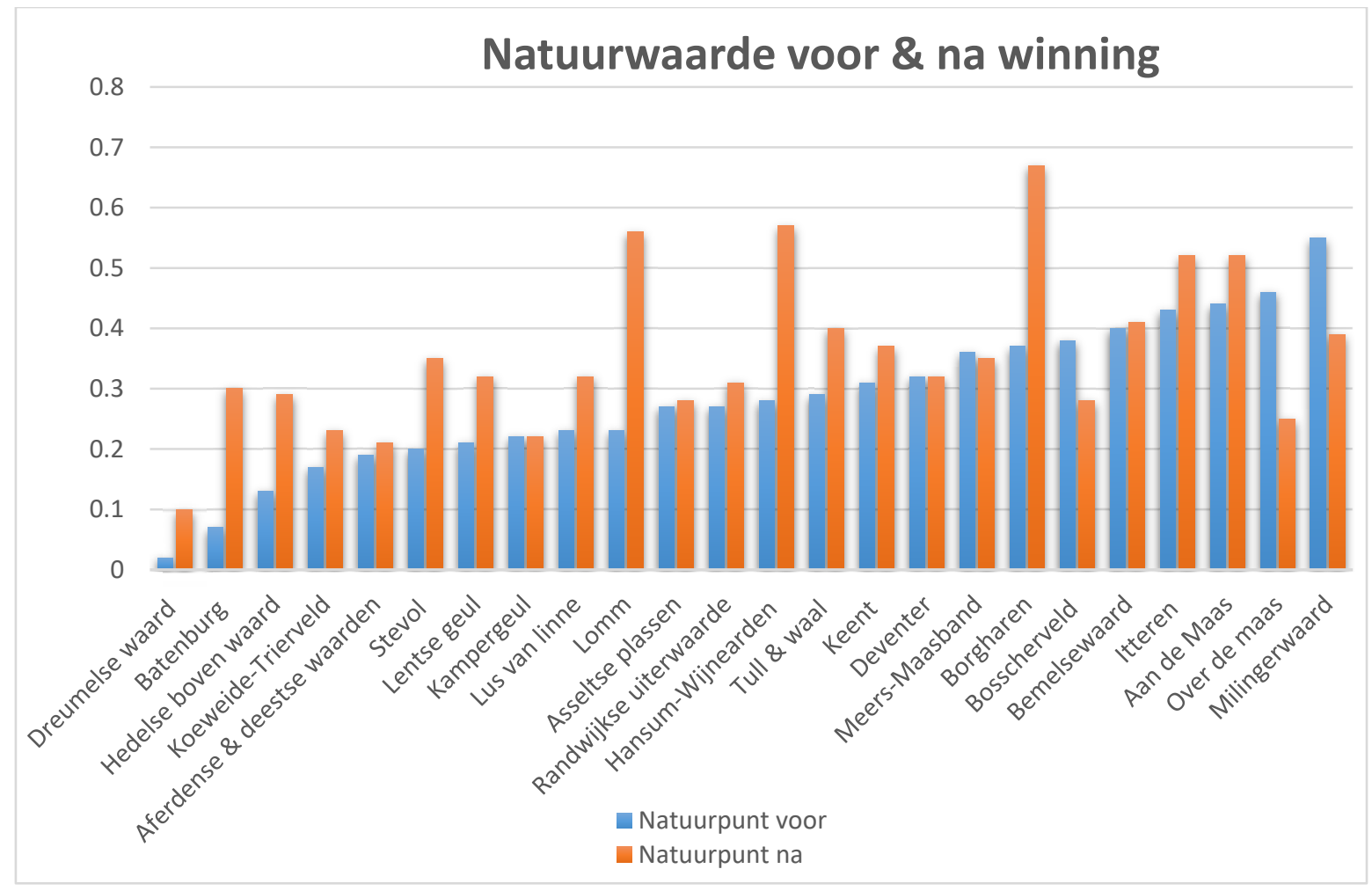

Figuur 7 Berekende natuurpunten per gebied voor en na de winning.

In Figuur 7 staan van alle gebieden de berekende natuurpunten weergegeven, gerangschikt in oplopende waarde voor de winning. Wat opvalt, is dat vrijwel in alle gebieden de natuurwaarde hoger is na de winning (oranje balk langer dan blauwe balk). Slechts in 3 gebieden is de natuurwaarde na de winning lager dan voor de winning. Een voor de hand liggende verklaring voor deze resultaten is dat voor de winning veel gebieden grotendeels uit landbouwgrond bestonden (bijv. maisakkers), waar de biodiversiteit erg laag is. Na de winning is de bestemming veelal natuur en kan deze zich ontwikkelen, vaak onder een beheer van begrazing. Een gebied waar de natuurwaarde na de winning lager is dan voor de winning is de Millingerwaard. Dit terrein was al een natuurgebied, waar in het kader van 'Ruimte voor de rivier' opnieuw een zandwinning plaats heeft gehad. Dit project liep tot 2016. Dat het aantal waargenomen soorten in de eerste twee jaar na de winning nog niet op het oude peil is, is niet verwonderlijk. Dit wordt geïllustreerd in Figuur 8. Standaard is voor het berekenen van de natuurpunten (data uit NDFF) een periode van 5 jaar voor en 5 jaar na de winning genomen. Een aantal gebieden is korter dan 5 jaar geleden opgeleverd en bij die gebieden is ook de periode voor de winning verkort tot eenzelfde lengte. Te zien is dat bij alle perioden de natuurwaarde na de winning gemiddeld hoger is dan voor de winning, behalve bij de periode van 2 jaar. Dit is blijkbaar nog een te korte periode voor veel soorten om zich te vestigen. 


\section{Gemiddelde score natuurpunt vs. waarnemingsperiode (in}

jaren)

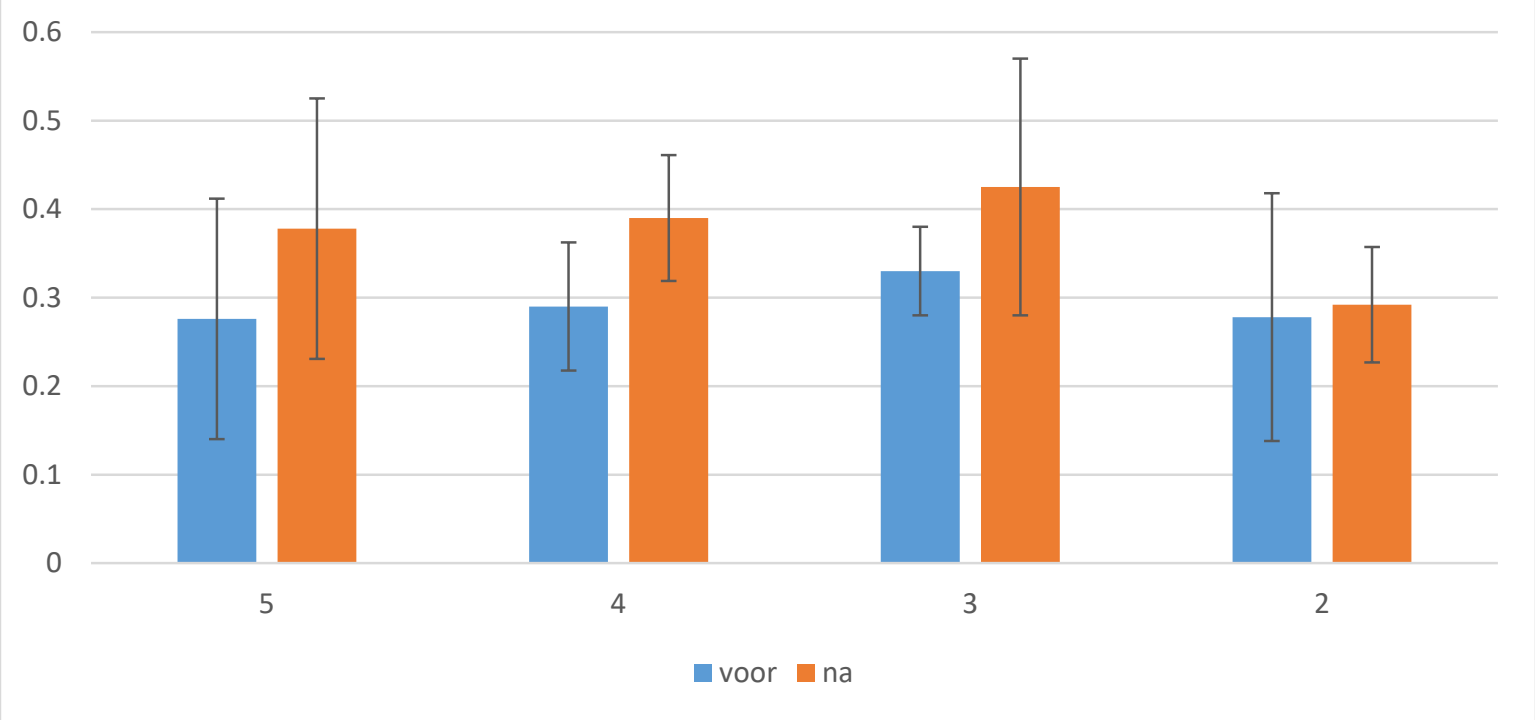

Figur 8 Gemiddelde score naturpunt vs lengte warnemingsperiode (inclusief standaardafwijking).

Om na te gaan of in grotere gebieden de score natuurpunt systematisch hoger is dan in kleinere gebieden (meer kans op het voorkomen/waarnemen van een soort), is de oppervlakte van het gebied uitgezet tegen het verschil in score natuurpunt (na - voor), zie Figuur 9. Bij een verschilscore groter dan 0 is sprake van een toename in natuurpunt; is hij lager dan 0 , dan is de score voor de winning hoger dan na de winning. Te zien is weer dat de meeste terreinen vooruitgaan qua natuurwaarde. Daarnaast is te zien dat er weinig verband is tussen toe- of afname in natuurwaarde en de oppervlakte van het gebied. (Ook de natuurwaarden voor of na de winning zelf vertonen weinig verband met de oppervlakte, niet in grafiek.)

\section{Toe of afname natuurpunten vs. oppervlakte}

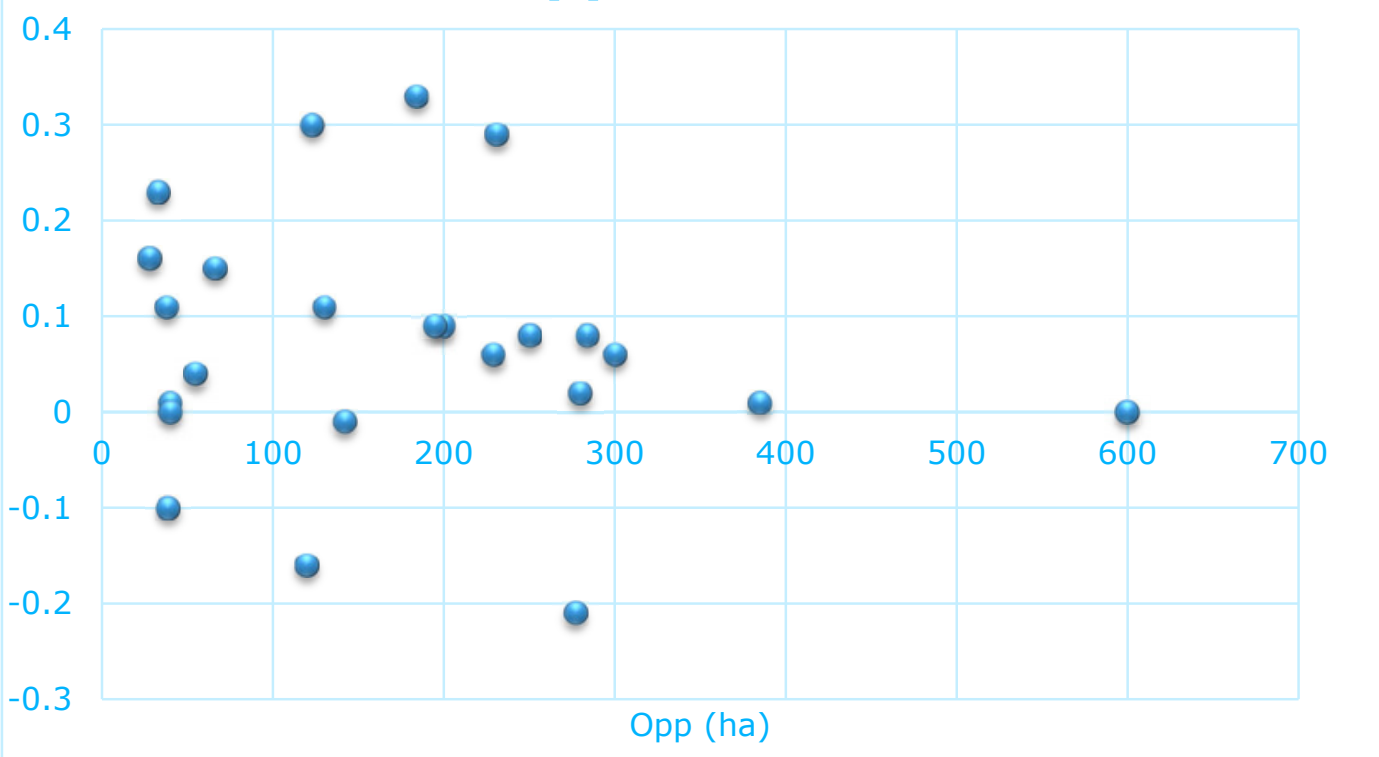

Figuur 9 Toe- of afname natuurwaarde vs. oppervlakte gebied. 
De natuurpuntscore wordt bepaald door het aandeel karakteristieke (referentie)soorten van de natuurtypen. Meer soorten hoeft dus niet automatisch te betekenen ook een hogere natuurwaarde, het gaat erom welke soorten.

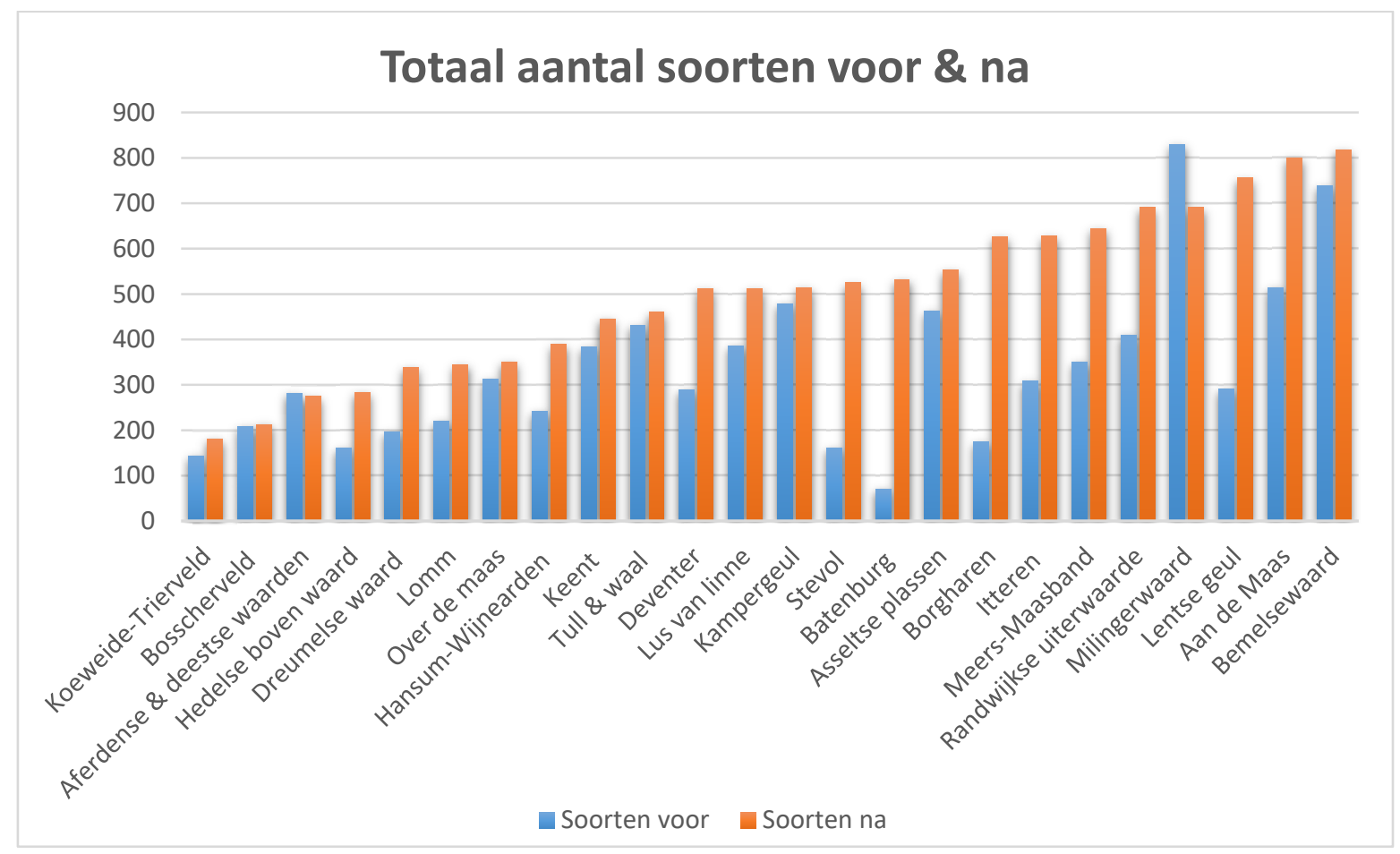

Figuur 10 Totaal aantal waargenomen soorten (6 soortgroepen) voor en na winning.

In Figuur 10 is het totaal aantal verschillende soorten van de 6 soortgroepen (vaatplanten, dagvlinders, libellen, vogels, vissen, zoogdieren) weergegeven voor en na de winning. Duidelijk is te zien dat het aantal soorten na de winning in vrijwel alle gebieden groter is dan voor de winning. In hoeverre speelt hier het effect mee dat door digitalisering en moderne apps het aantal waarnemingen in de NDFF in de laatste jaren (periode 'na de winning') flink groter is dan bijvoorbeeld 15 jaar geleden ('periode voor de winning')?

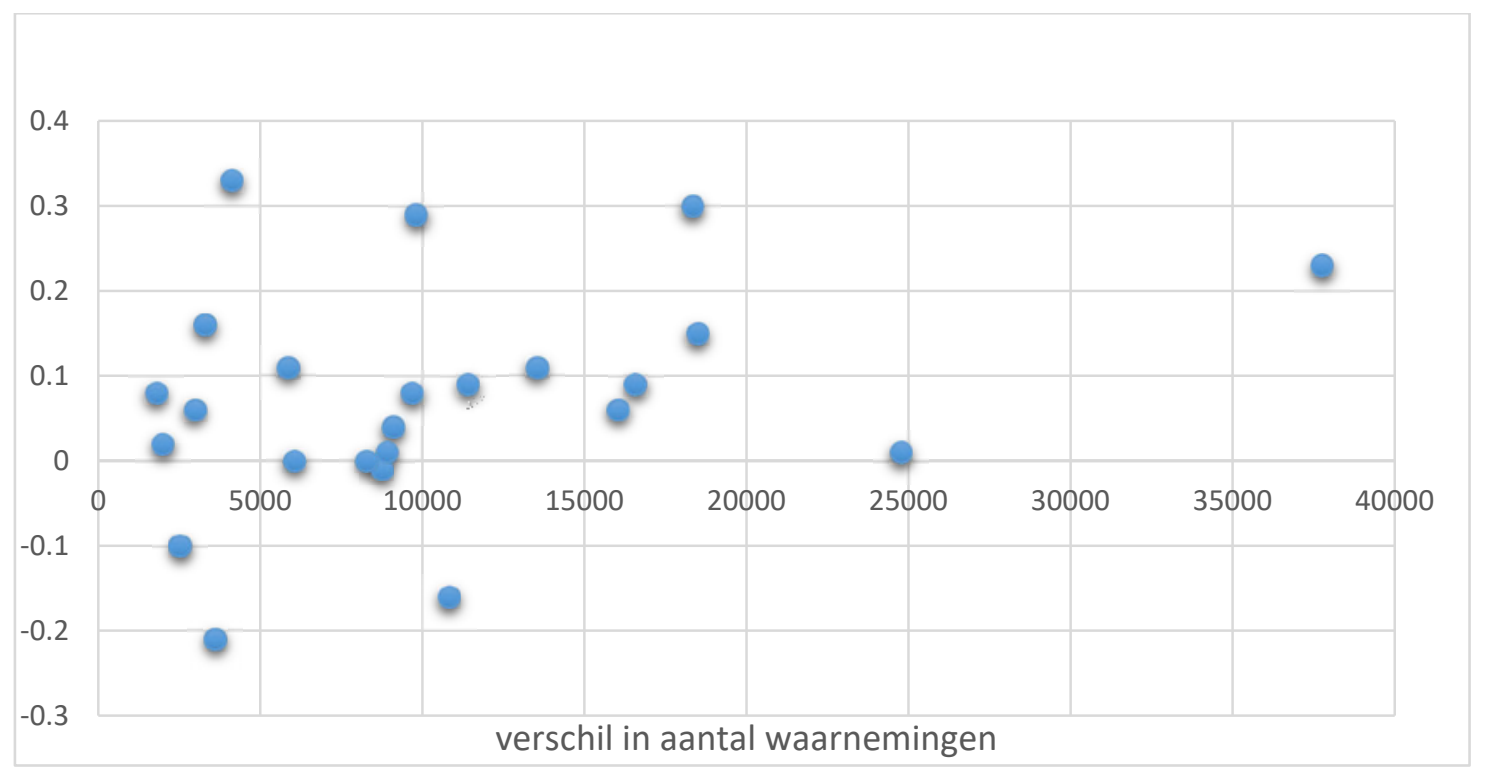

Figuur 11 Verschil in natuurwaarde (na - voor) vs. het verschil in aantal waarnemingen (na - voor). 
Om dat te onderzoeken, is in Figuur 11 het verschil in natuurpunt uitgezet tegen het verschil in het aantal waarnemingen ( $\mathrm{na}$ - voor). Duidelijk is te zien dat het aantal waarnemingen in de periode na de winning flink is toegenomen ten opzichte van de (even lange) periode voor de winning. Maar dit heeft weinig relatie met de toename in natuurkwaliteit. Met andere woorden: er zijn voor de periode na de winning veel meer waarnemingen ingevoerd in de NDFF, maar het zijn veelal dezelfde soorten. De aanwezige referentiesoorten worden dus sowieso wel waargenomen. Dit is voor het onderzoek een plezierige conclusie. Het betekent dat geen correctie hoeft te worden verzonnen voor het grotere aantal in de NDFF ingevoerde waarnemingen van de laatste jaren.

\subsubsection{Natuurwaarde afzonderlijke soortgroepen}

\section{Dagvlinders}

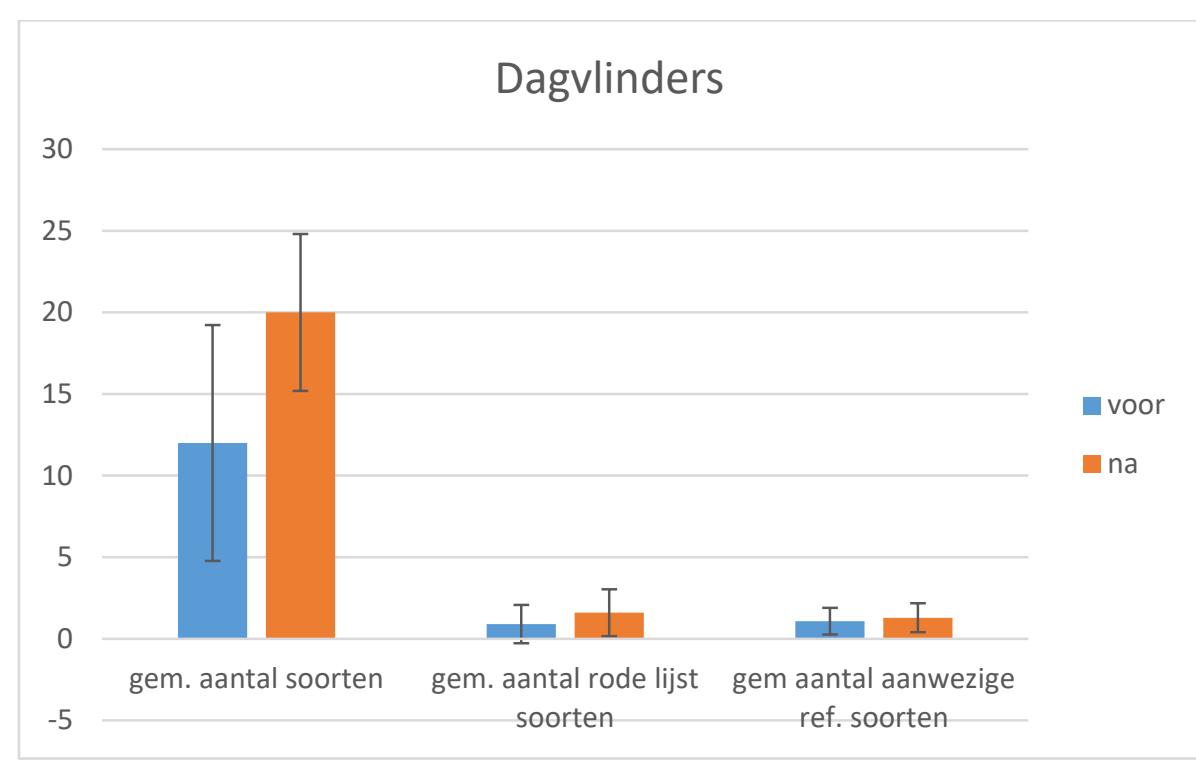

Figuur 12 Aantal soorten dagvlinders voor (blauw) en na (oranje) de winning. Weergegeven zijn het totaal aantal soorten, het aantal Rode Lijstsoorten en het aantal referentiesoorten t.b.v. berekening natuurpunten.

Het aantal soorten dagvlinders dat gemiddeld in een gebied is aangetroffen voor de winning is 12,0 en na de winning 20,0 , een toename van $67 \%$. Het aantal Rode Lijstsoorten en referentiesoorten is een stuk lager, maar ook zijn de aantallen na de winning iets groter dan voor de winning. De toename in het aantal dagvlinders betreft dus vooral algemene soorten. 


\section{Libellen}

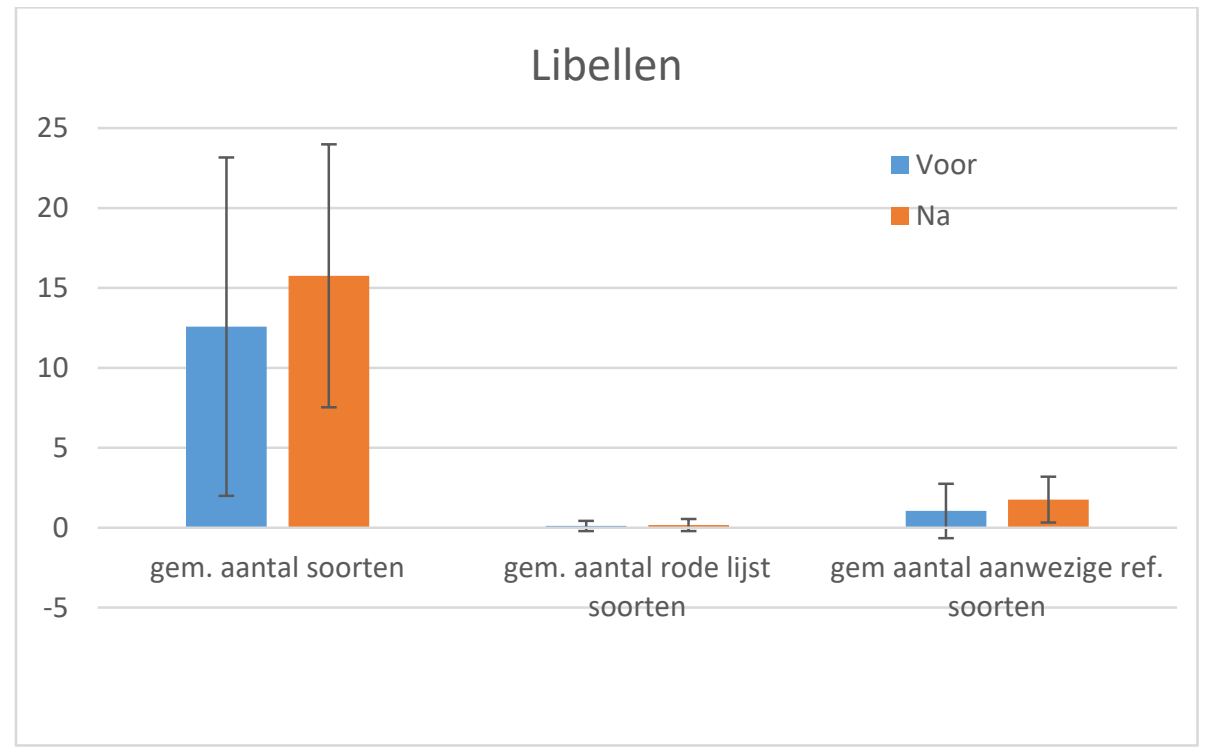

Figuur 13 Aantal soorten libellen voor (blauw) en na (oranje) de winning. Weergegeven zijn het totaal aantal soorten, het aantal Rode Lijstsoorten en het aantal referentiesoorten t.b.v. berekening natuurpunten.

Het aantal soorten libellen dat gemiddeld in een gebied is aangetroffen voor de winning is 12,6 en na de winning 15,8 , een toename van $25,3 \%$. Het aantal Rode Lijstsoorten en referentiesoorten is een stuk lager, maar ook zijn de aantallen na de winning iets groter dan voor de winning. De toename in het aantal libellen betreft dus vooral algemene soorten.

\section{Vaatplanten}

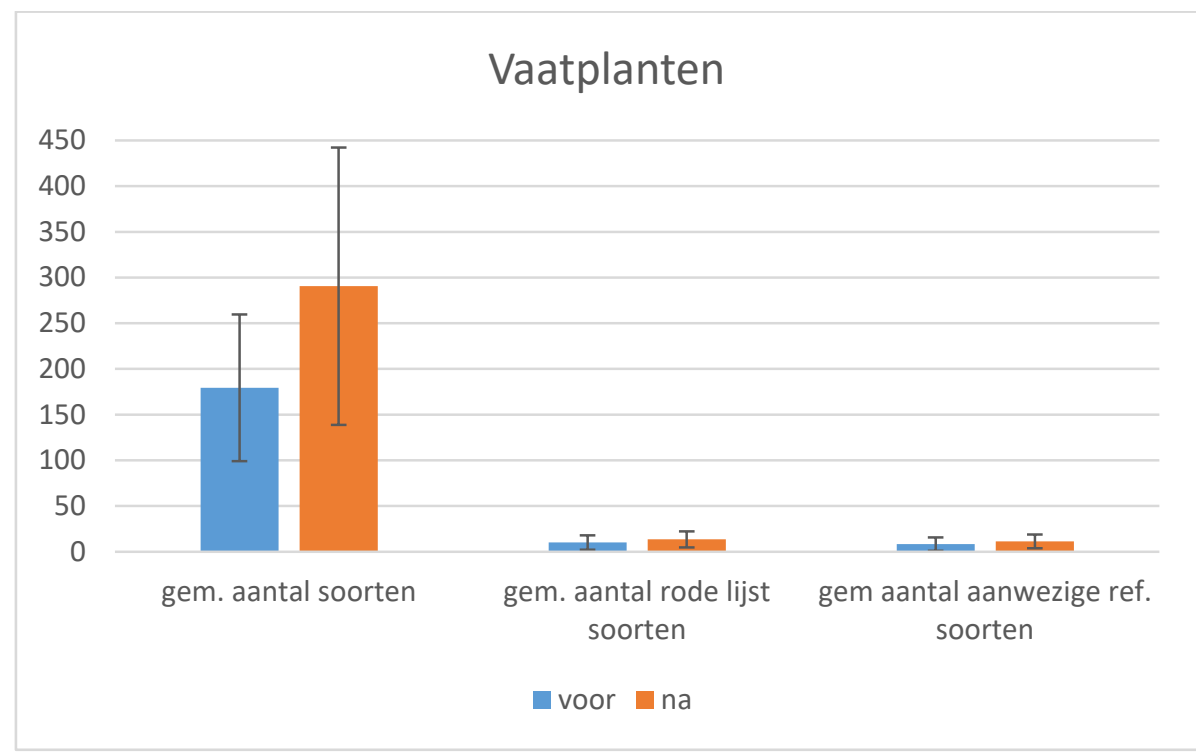

Figuur 14 Aantal soorten vaatplanten voor (blauw) en na (oranje) de winning. Weergegeven zijn het totaal aantal soorten, het aantal Rode Lijstsoorten en het aantal referentiesoorten t.b.v. berekening natuurpunten.

Het aantal soorten vaatplanten dat gemiddeld in een gebied is aangetroffen voor de winning is 179 en na de winning 291, een toename van $62 \%$. Het aantal Rode Lijstsoorten en referentiesoorten is een stuk lager, maar ook zijn de aantallen na de winning iets groter dan voor de winning. De toename in het aantal vaatplanten betreft dus vooral algemene soorten. 


\section{Vogels}

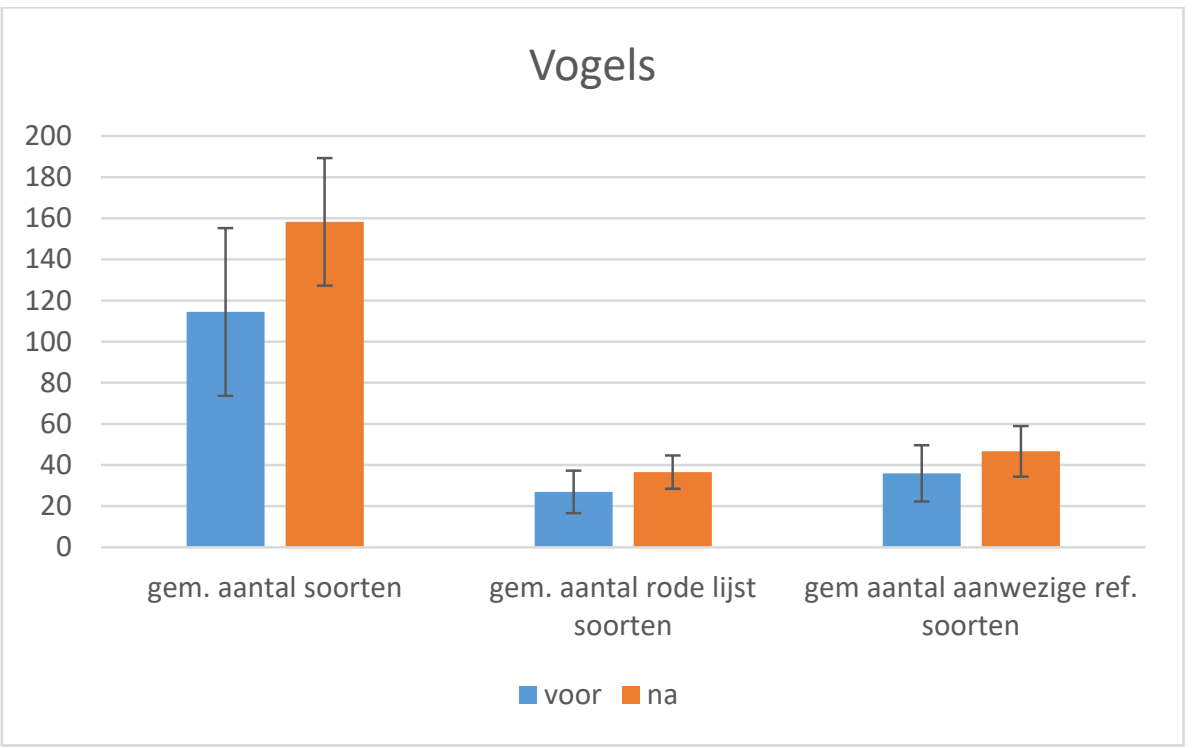

Figuur 15 Aantal soorten vogels voor (blauw) en na (oranje) de winning. Weergegeven zijn het totaal aantal soorten, het aantal Rode Lijstsoorten en het aantal referentiesoorten t.b.v. berekening natuurpunten.

Het aantal soorten vogels dat gemiddeld in een gebied is aangetroffen voor de winning is 114 en na de winning 158, een toename van 38,3\%. Het aantal Rode Lijstsoorten en referentiesoorten is lager, maar ook zijn de aantallen na de winning groter dan voor de winning. Vergeleken met dagvlinders, libellen en vaatplanten is het aantal Rode Lijstsoorten bij vogels relatief hoog. De toename in het aantal vogels betreft naast algemene soorten dus ook een aantal zeldzame soorten.

\section{Vissen}

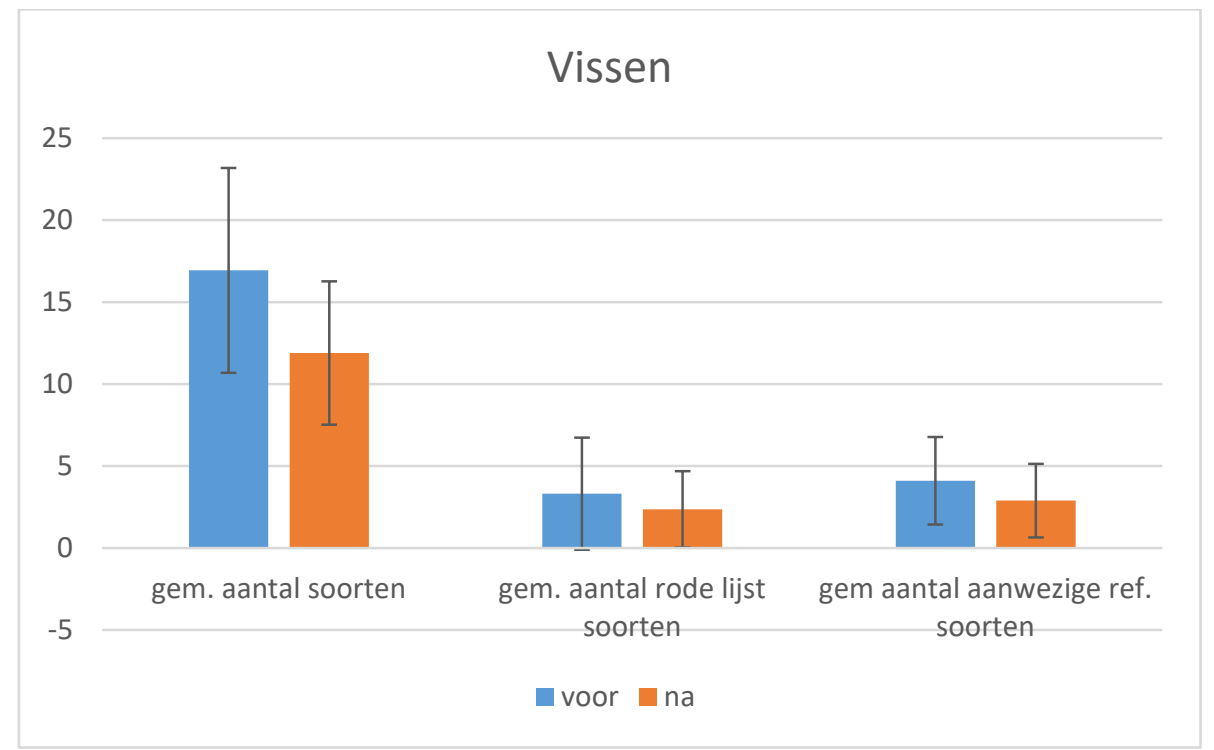

Figuur 16 Aantal soorten vissen voor (blauw) en na (oranje) de winning. Weergegeven zijn het totaal aantal soorten, het aantal Rode Lijstsoorten en het aantal referentiesoorten t.b.v. berekening natuurpunten. 
Het aantal soorten vissen dat gemiddeld in een gebied is aangetroffen voor de winning is 16,9 en na de winning 11,9 , een afname van $29,8 \%$. Het aantal Rode Lijstsoorten en referentiesoorten is lager, maar ook zijn de aantallen na de winning lager dan voor de winning. Vergeleken met dagvlinders, libellen en vaatplanten is het aantal Rode Lijstsoorten bij vissen relatief hoog. De afname in het aantal vissen betreft naast algemene soorten dus ook een aantal zeldzame soorten.

\section{Zoogdieren}

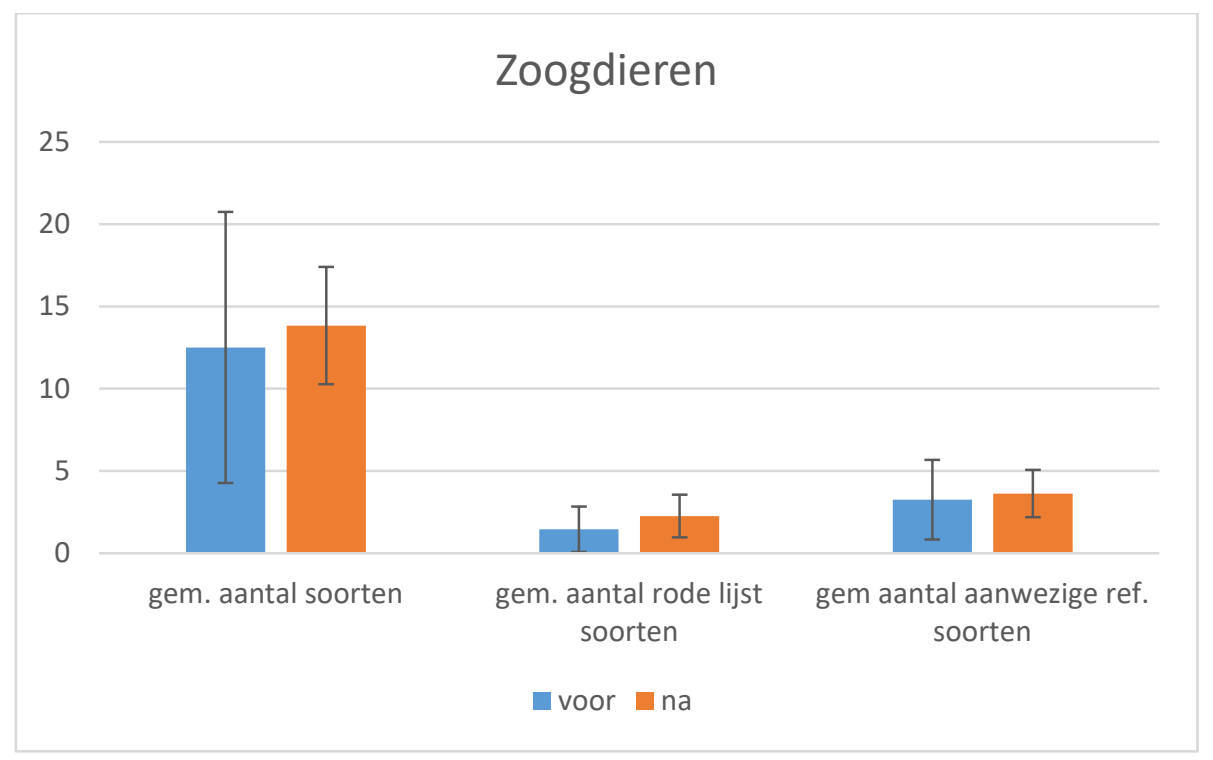

Figuur 17 Aantal soorten zoogdieren voor (blauw) en na (oranje) de winning. Weergegeven zijn het totaal aantal soorten, het aantal Rode Lijstsoorten en het aantal referentiesoorten t.b.v. berekening natuurpunten.

Het aantal soorten zoogdieren dat gemiddeld in een gebied is aangetroffen voor de winning is 12,5 en na de winning 13,8, een kleine toename met 10,6\%. Het aantal Rode Lijstsoorten en referentiesoorten is lager, maar ook zijn de aantallen na de winning iets groter dan voor de winning. De spreiding in aantallen zoogdieren tussen de gebieden is groot en statistisch zijn de verschillen niet significant. Ten aanzien van zoogdieren kunnen we dus stellen dat voor en na de winning het aantal waargenomen soorten ongeveer hetzelfde is.

\subsubsection{Samenvattend}

Vergelijken we de aantallen soorten aangetroffen voor en na de winning, dan zien we bij alle soortgroepen - met uitzondering van vissen - grotere aantallen na de winning. Dagvlinders, vaatplanten en vogels vertonen de sterkste stijging in aantal. Ook de aantallen soorten libellen gaan vooruit. Het aantal soorten zoogdieren voor en na de winning is min of meer gelijk, alleen het aantal soorten vissen is lager na de winning dan voor de winning. Bij de toename gaat het vooral om algemene soorten, bij de Rode Lijstsoorten en referentiesoorten is de toename veel minder groot. 


\subsubsection{Van welke soortgroepen nemen de aantallen soorten toe of af?}

Tabel 4 Aantal soorten dat is toegenomen, gelijk gebleven of achteruitgegaan in de 24 gebieden.

\begin{tabular}{|c|c|c|c|c|c|c|c|}
\hline & achteruit & $\%$ & gelijk & $\%$ & vooruit & $\%$ & totaal \\
\hline vlinders & 3 & $8 \%$ & 1 & $3 \%$ & 34 & $89 \%$ & 38 \\
\hline libellen & 10 & $21 \%$ & 8 & $17 \%$ & 30 & $63 \%$ & 48 \\
\hline libellen doelsoorten & 0 & & 1 & $14 \%$ & 6 & $86 \%$ & 7 \\
\hline vaatplanten natte doelsoorten & 3 & $14 \%$ & 2 & $10 \%$ & 16 & $76 \%$ & 21 \\
\hline vaatplanten stroomdalplanten (droge doelsoorten) & 6 & $27 \%$ & 8 & $36 \%$ & 8 & $36 \%$ & 22 \\
\hline vaatplanten vochtige alluviale bossen & 2 & $17 \%$ & 5 & $42 \%$ & 5 & $42 \%$ & 12 \\
\hline vogels & 42 & $14 \%$ & 28 & $9 \%$ & 228 & $77 \%$ & 298 \\
\hline zoogdieren & 18 & $39 \%$ & 10 & $22 \%$ & 18 & $39 \%$ & 46 \\
\hline
\end{tabular}

Van alle soorten is nagegaan of ze voor en na de delfstofwinning zijn waargenomen in het terrein. Het totaal aantal terreinen waar zowel voor als na de winning gegevens van bekend zijn, is 24 . Soorten kunnen na de winning zijn waargenomen en voor de winning niet of omgekeerd. In dat terrein is de soort dus vooruitgegaan respectievelijk achteruitgegaan. Ook kunnen soorten zowel voor als na de winning wel of niet aanwezig zijn. In bovenstaande tabel is van elke soort het verschil berekend tussen het aantal terreinen waar de soort vooruit is gegaan en het aantal terreinen waar de soort achteruit is gegaan. Over 24 gebieden kunnen we dus per soort aangeven of deze gemiddeld vooruit is gegaan, gelijk gebleven of achteruit is gegaan. Ook op deze manier berekend, blijkt dat met name het aantal soorten dagvlinders, vaatplanten, vogels en libellen is toegenomen na de winning, het aantal soorten zoogdieren is ongeveer gelijk gebleven en het aantal soorten vissen is afgenomen.

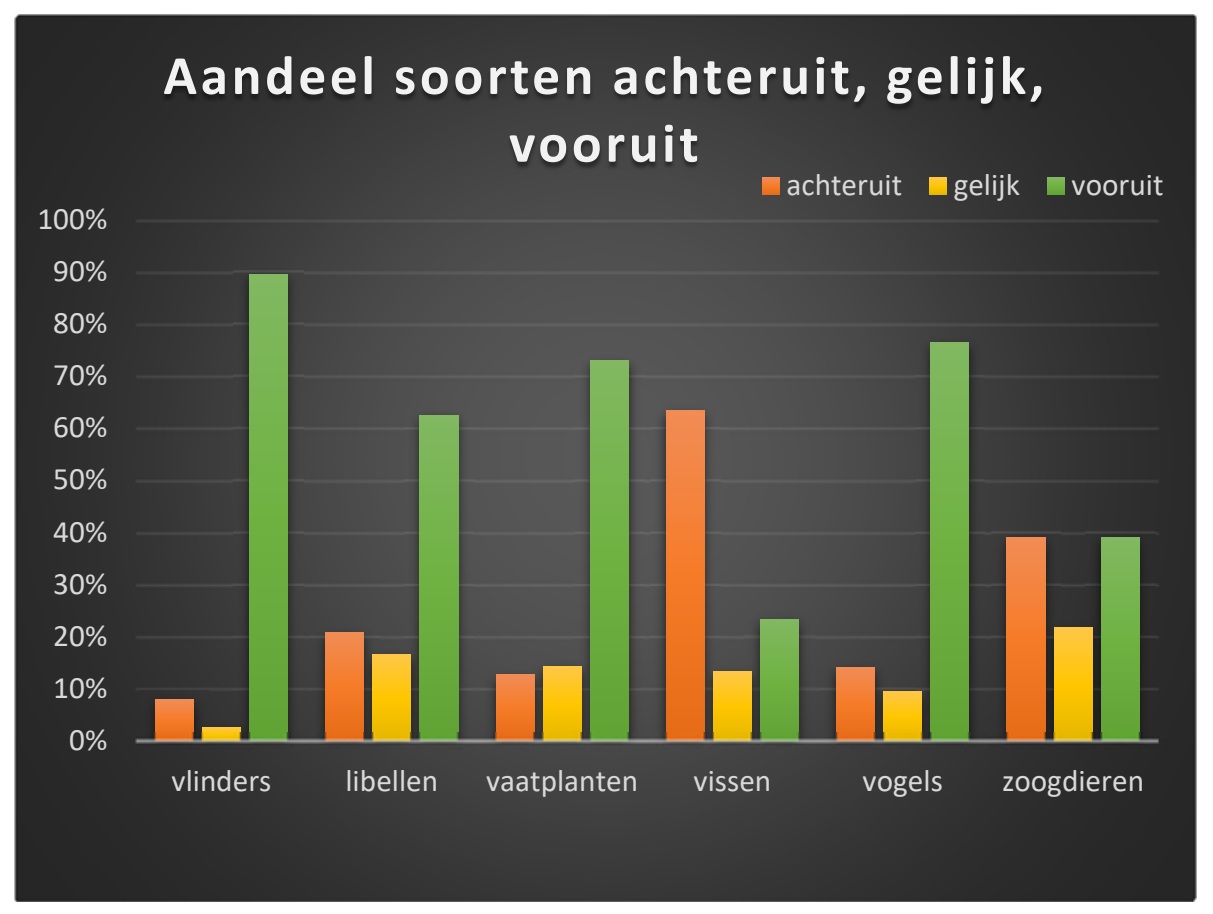

Figuur 18 Het percentage soorten per soortgroep dat is achteruitgegaan, gelijk gebleven en is toegenomen in 24 gebieden na de winning t.o.v. voor de winning. 
Als we de analyse beperken tot alleen de zgn. doelsoorten voor het rivierengebied (zie Figuur 19), dan zien we bij de vaatplanten een opvallend verschil tussen de planten van natte milieus (mee stromende nevengeul en stilstaande oude rivierarm) en de stroomdalplanten van droge milieus. Het aantal doelsoorten van natte milieus neemt toe, maar bij de stroomdalplanten is het aantal soorten dat verdwijnt ongeveer even groot als het aantal soorten dat verschijnt na de winning.

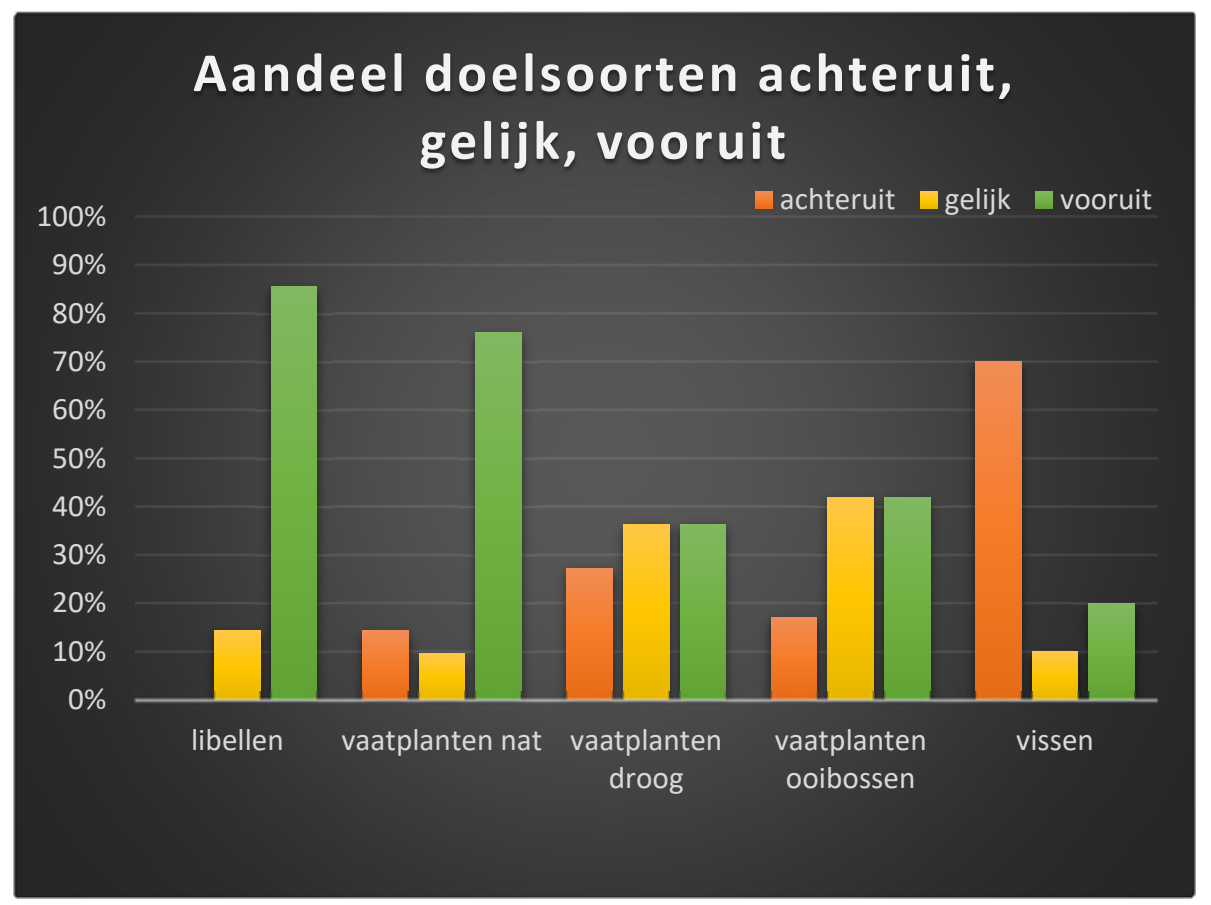

Figuur 19 Het percentage doelsoorten rivierengebied per soortgroep dat is achteruitgegaan, gelijk gebleven en is toegenomen in 24 gebieden na de winning t.o.v. voor de winning.

\section{Vlinders}

Vlindersoorten die achteruit zijn gegaan (8\%): Staartblauwtje, Grote vos en Resedawitje. Dit betreft zeldzame soorten (zwervers) die ook voor de delfstofwinning maar in één gebied zijn waargenomen.

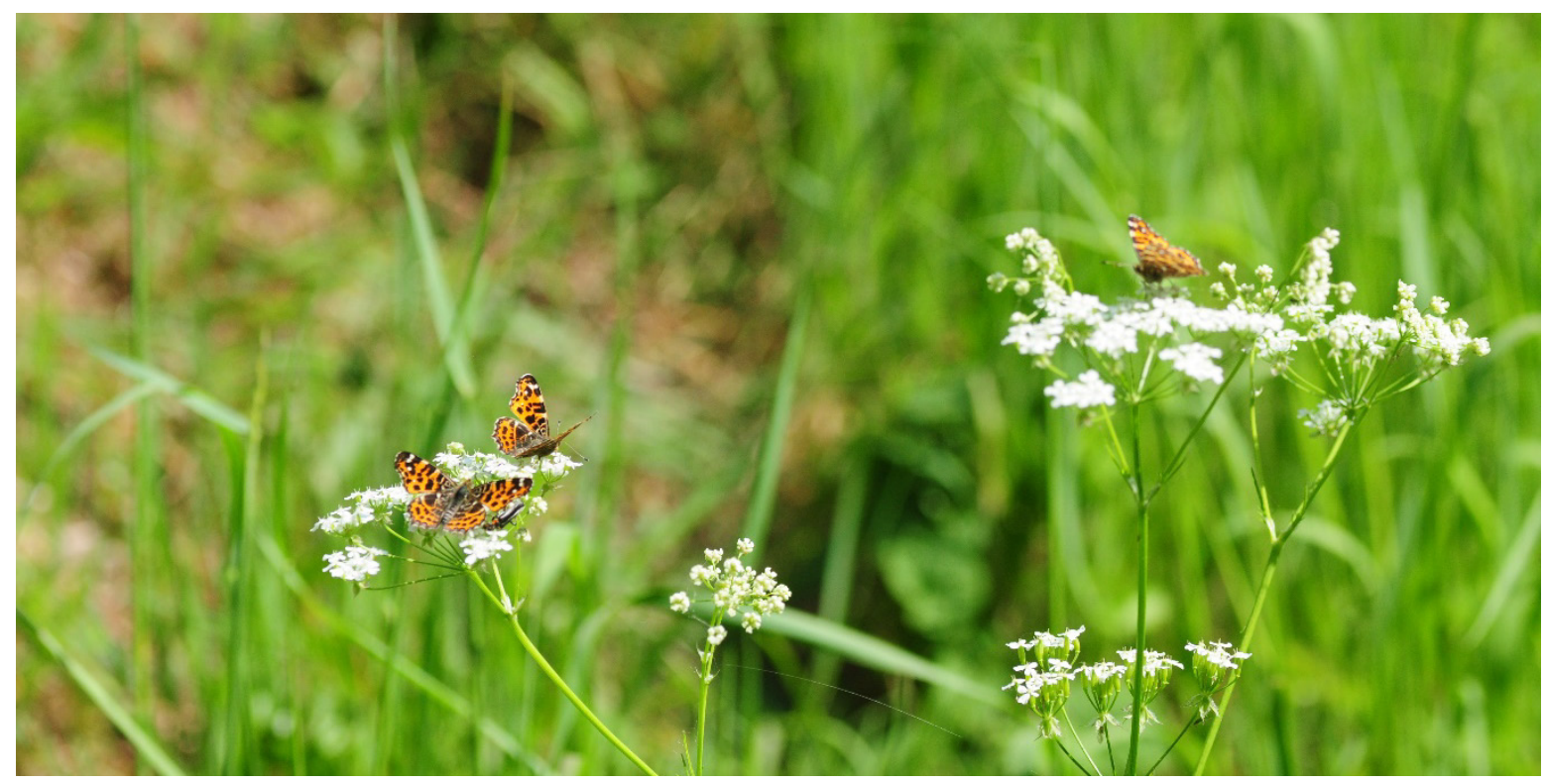

Foto $7 \quad$ Het landkaartje komt pas voor als het gebied zich wat verder heeft ontwikkeld (Foto: Albert Vliegenthart). 
Vlindersoorten die het meest vooruit zijn gegaan (90\%): Gehakkelde aurelia, Zwartsprietdikkopje, Distelvlinder, Oranje zandoogje, Icarusblauwtje, Klein geaderd witje, Oranjetipje, Oranje luzernevlinder, Bont zandoogje, Groot koolwitje, Hooibeestje, Bruin zandoogje, Boomblauwtje, Citroenvlinder, Kleine vuurvlinder en Landkaartje. Dit betreft tamelijk algemene soorten die profiteren van het feit dat landbouwgrond is omgezet in natuur. Er zit een aantal trekvlinders tussen die flinke afstanden kunnen afleggen, zoals de distelvlinder en oranje luzernevlinder. Deze soorten kunnen zich doorgaans niet handhaven, maar gebruiken de gebieden voor voedsel en tijdelijke voortplanting (de nakomelingen vliegen terug naar het zuiden). Opmerkelijk is dat het bruin blauwtje, een echte soort van het rivierengebied, niet is toegenomen.

\section{Libellen}

Libellen die het meest achteruit zijn gegaan (21\%): Viervlek, Blauwe glazenmaker, Zwervende pantserjuffer, Metaalglanslibel, Geelvlekheidelibel, Gewone pantserjuffer en Tengere pantserjuffer.

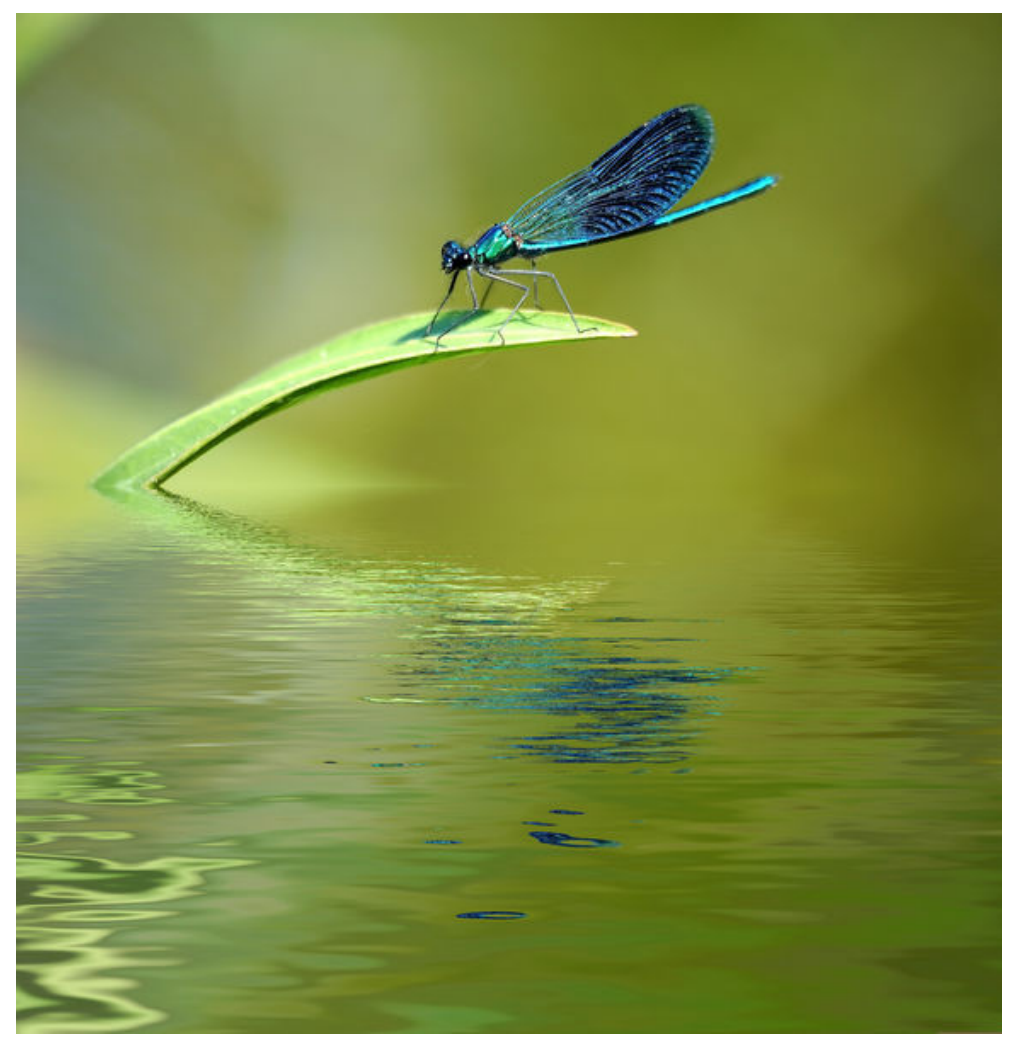

Foto 8 Weidebeekjuffer (Foto: Archief WUR).

Libellen die het meest vooruit zijn gegaan (63\%): Bruine glazenmaker, Kleine roodoogjuffer, Tengere grasjuffer, Steenrode heidelibel, Bruinrode heidelibel, Bloedrode heidelibel, Zwervende heidelibel, Paardenbijter, Gewone oeverlibel, Watersnuffel, Weidebeekjuffer, Bruine winterjuffer, Grote keizerlibel. De Viervlek en Gewone Pantserjuffer indiceren een meer zuur milieu, de achteruitgang van deze soorten lijkt op een verbetering van de waterkwaliteit (Bos et al. 2006). De Geelvlekheidelibel is nagenoeg verdwenen uit Europa. Bij de toenemende soorten lijkt de waterkwaliteit een rol te spelen.

\section{Vaatplanten}

Een selectie van vaatplanten die het meest achteruit zijn gegaan (13\%): Ruige weegbree, Elzenzegge, Blaaszegge, Vlottende waterranonkel, Sofiekruid, Melkeppe, Zeegroene muur, Moeslook, Knolsteenbreek, Haarfonteinkruid, Grote bevernel. Hierbij (vetgedrukt) enkele relatief zeldzame soorten die kenmerkend zijn voor het rivierengebied.

Een selectie van vaatplanten die het meest vooruit zijn gegaan (73\%): Klein liefdegras, Beklierde basterdwederik, Heggenrank, Hoge fijnstraal, Akkerereprijs, Citroengele honingklaver, Kruipertje, Aarvederkruid, Tuinbingelkruid, Grote ereprijs, Boswilg, Okkernoot, Beekpunge, Rode waterereprijs, Pinksterbloem, Canadese fijnstraal, Gewone vogelmelk, Kantige basterdwederik, Heelblaadjes, 
Poelruit, Wilde cichorei, Gehoornde klaverzuring, Muurvaren, Veldsla, Duinriet, Wouw, Kleine brandnetel, Knikkend tandzaad, Bruin cypergras, Zeegroene rus, Blaartrekkende boterbloem, Echte valeriaan, Moerasvergeet-mij-nietje, Vlinderstruik, Blauw glidkruid, Rode ogentroost, Hazenpootje, Rode ganzenvoet, Gewone brunel, Kroontjeskruid, Blauwe waterereprijs, Viltige basterdwederik, Tijmereprijs. Veel van deze soorten zijn pioniersoorten (een- of tweejarig) of soorten van voedselrijke vochtige grond (oevers).

\section{Vissen}

Vissen die het meest achteruit zijn gegaan (63\%): Ruisvoorn, Pos, Paling, Zeelt, Blankvoorn, Cottus, Giebel, Riviergrondel, Alver, Baars, Bermpje, Kleine modderkruiper, Winde, Karper.

Vissen die het meest vooruit zijn gegaan (23\%): Kesslers grondel, Marmergrondel, Zwartbekgrondel. Dit zijn alle drie uitheemse vissen, afkomstig uit de Zwarte Zee. Via het Main-Donaukanaal hebben deze soorten de laatste 15 jaar het stroomgebied van de Rijn gekoloniseerd. Door hun sterke kolonisatiedrift worden ze als invasieve exoot beschouwd en kunnen ze een bedreiging vormen voor inheemse soorten als Riviergrondel en Bermpje. Het is dan ook niet toevallig dat deze laatste soorten juist zijn afgenomen. Maar ook de diepe plassen die na een zand- of grindwinning achterblijven zullen een rol spelen. Vissen hebben een bodem nodig die op bereikbare diepte zit.

\section{Vogels}

Vogels die het meest achteruit zijn gegaan (14\%): Klapekster, Pestvogel, Magelhaengans, Chinese Knobbelgans, IJsgors, Gestreepte Strandloper, Kwartelkoning, Kievit, Roodhalsfuut, Europese Kanarie. Het zijn veelal tamelijk zeldzame doortrekkers of dwaalgasten.

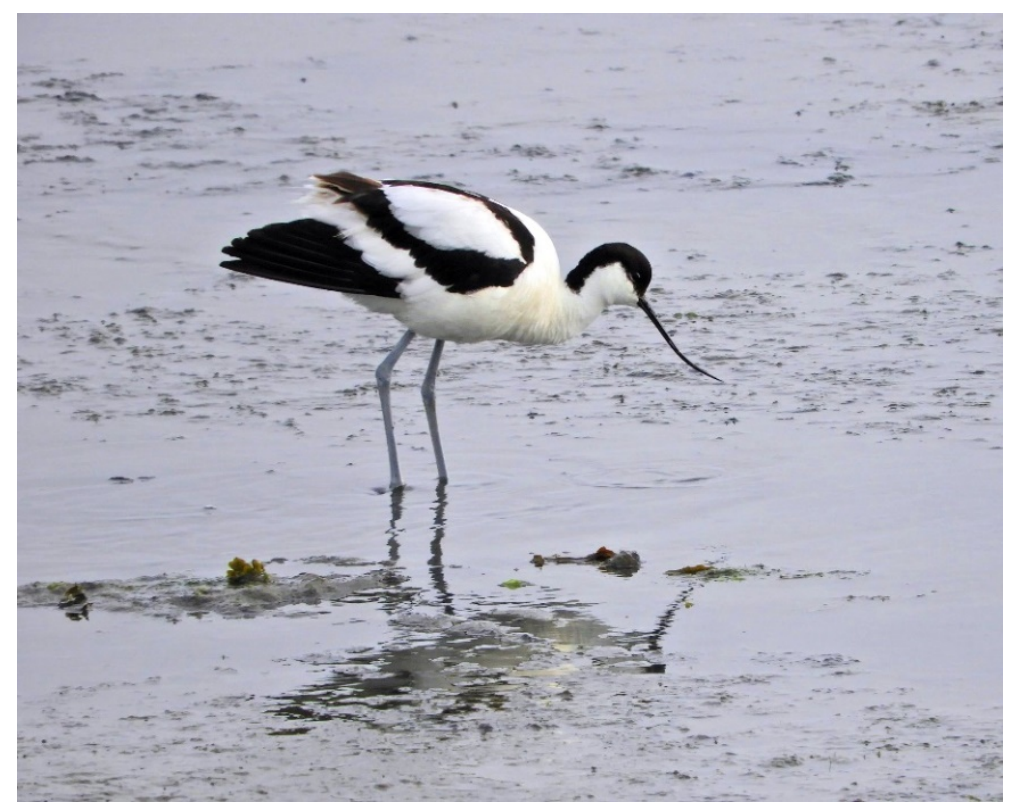

Foto 9

Kluut (Foto: Friso van der Zee).

Vogels die het meest vooruit zijn gegaan (77\%): Geoorde Fuut, Engelse Kwikstaart, Huiszwaluw, Zwarte Stern, Toendrarietgans, Zwarte Ruiter, Noordse Kwikstaart, Indische Gans, Gierzwaluw, Keep, Kemphaan, Zwartkopmeeuw, Rietzanger, Temmincks Strandloper, Regenwulp, Boompieper, Gekraagde Roodstaart, Kluut, Bosruiter, Drieteenstrandloper, Goudhaan, Bonte Strandloper, Blauwborst, Lepelaar, Pontische Meeuw, Bontbekplevier. Hier zitten veel soorten tussen van oevers en ondiep water die snel nieuw gegraven poelen en nevengeulen koloniseren.

\section{Zoogdieren}

Zoogdieren die het meest achteruit zijn gegaan (39\%): Aardmuis, Watervleermuis, Rosse woelmuis, Meervleermuis, Huisspitsmuis, Dwergspitsmuis. Dit zijn relatief kleine dieren die meestal door specialisten worden waargenomen. 
Zoogdieren die het meest vooruit zijn gegaan (39\%): Das, Bruine rat, Haas, Ree, Konijn, Wezel, Vos, Mol, Bever. Dit zijn veelal grotere en relatief makkelijk waarneembare dieren in vergelijking met de soorten die achteruit zijn gegaan. Hier zal het waarnemingseffect een belangrijke rol spelen. En de bever is landelijk aan een opmars bezig, wat ook hier goed merkbaar is.

\subsubsection{Deelonderzoek Hedelse Bovenwaard}

Doel van dit deelonderzoek was een nadere analyse van de bruikbaarheid van het natuurpuntensysteem. Het is in Nederland lastig om vergelijkbare gebieden te vinden met dezelfde samenstelling van natuurdoeltypen. Daarbij treedt ook een verschil op tussen de aangewezen doelstelling voor natuurdoeltypen en de werkelijke aanwezige natuurdoeltypen (ze zijn nog in ontwikkeling). De huidige indeling van natuurtypen van de Hedelse Bovenwaard zijn moeras langs plas en geïsoleerde strang (30\%), rietland en ruigte $(10 \%)$, nat schraalgrasland $(30 \%)$, stroomdalgrasland $(10 \%)$ en bosgemeenschappen van rivierklei $(15 \%)$. De overige $5 \%$ van het landschap is ongedefinieerd. Het streefbeeld is: $40 \%$ bloemrijk grasland, $20 \%$ stroomdalgrasland, $20 \%$ vochtig kleibos en $20 \%$ moeras (Rademakers, 2013). Het huidige indeling van natuurtypen in de Bijlandse Waard is rivierboslandschap in vrij afstromend riviertraject (95\%), 5\% van het gebied is ongedefinieerd (CBS et al. 2015). Beide gebieden zijn ontwikkeld vanuit landbouwgrond waarvan nu even wordt aangenomen dat doelsoorten niet aanwezig waren.

\section{Aantal soorten}

Figuur 20 geeft een overzicht van de aantallen soorten vogels (resp. 125/165), dag- en nachtvlinders (resp. 21/16 + 8/3), libellen (resp. 20/15) en planten (resp. 216/137) die vanuit de NDFF bekend zijn van de Hedelse Bovenwaard en de Bijlandse Waard. Sinds de ontwikkeling zijn in totaal zijn 374 soorten in de Hedelse Bovenwaard en 335 in de Bijlandse Waard waargenomen vanaf respectievelijk 1999 en 2007.

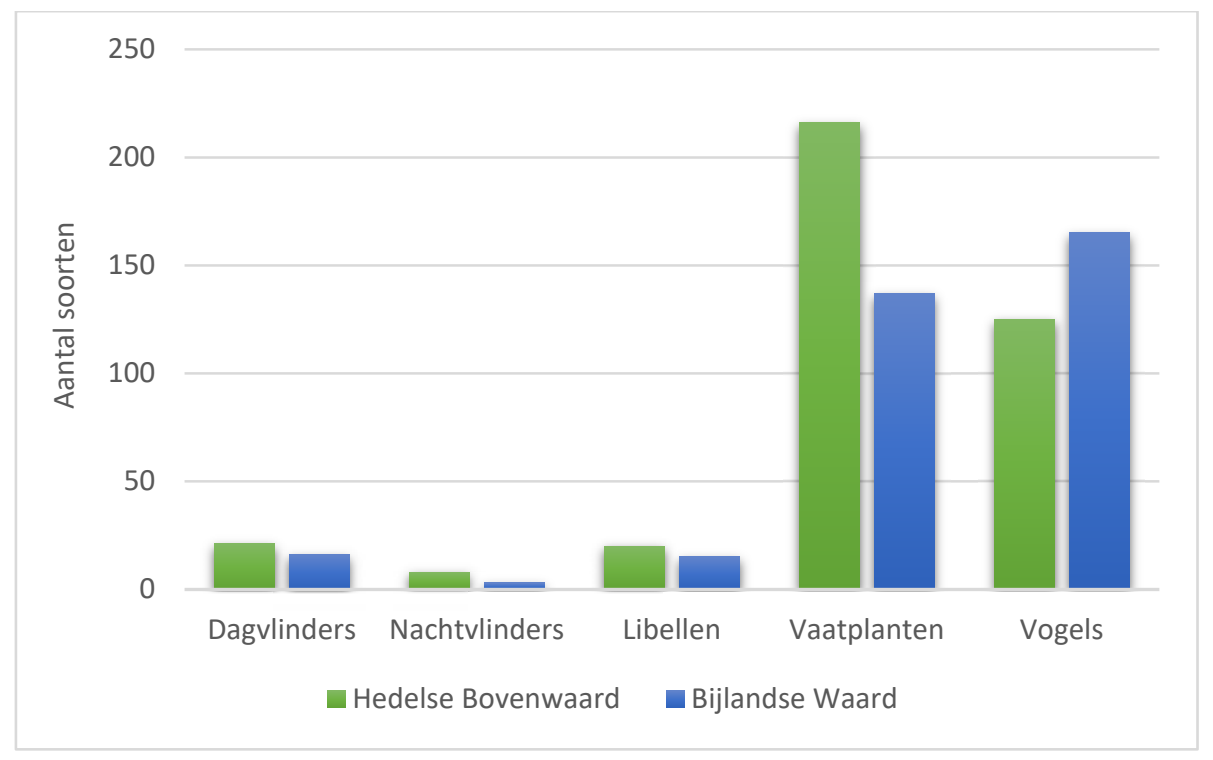

Figuur 20 Aantal voorkomende soorten per soortgroep in de Hedelse Bovenwaard en Bijlandse Waard.

Onder de waargenomen soorten zijn doelsoorten van de specifieke natuurdoeltypen. Het aantal doelsoorten van de specifieke natuurdoeltypen is voor de Hedelse Bovenwaard uitgelicht in Tabel 5 als eerste indicatie van de natuurkwaliteit. 
Tabel 5 Het percentage doelsoorten van verschillende naturtypen dat voorkomt in de Hedelse Bovenwaard sinds 1999. Een - (streepje) betekent dat er geen doelsoorten bij dit natuurtype horen.

\begin{tabular}{lllll} 
& Moeras & Stroomdalgrasland & Vochtig kleibos & Bloemrijk grasland \\
Dagvlinders & - & $1 / 2(50 \%)$ & - & - \\
\hline Libellen & $2 / 3(67 \%)$ & - & - & - \\
\hline Vaatplanten & $2 / 9(22 \%)$ & $3 / 58(5 \%)$ & $0 / 1(0 \%)$ & $0 / 5(0 \%)$ \\
\hline Vogels & $13 / 18(72 \%)$ & $13 / 21(62 \%)$ & $4 / 10(40 \%)$ & $17 / 26(65 \%)$ \\
\hline Totaal & $\mathbf{5 7 \%}$ & $\mathbf{2 1 \%}$ & $\mathbf{3 6 \%}$ & $\mathbf{5 5 \%}$ \\
\hline
\end{tabular}

Vooral moerasdoelsoorten en soorten van bloemrijke graslanden zijn vertegenwoordigd in de Hedelse Bovenwaard. De afwisseling van habitat zorgt voor relatief veel vogelsoorten. Bij libellen zijn er slechts 3 doelsoorten, waarvan er 2 aanwezig zijn. Dit zijn indicatoren voor een goede waterkwaliteit. Algemenere soorten zijn het best vertegenwoordigd. Om een vergelijking te maken van de twee onderzochte gebieden zijn de doelsoorten en soorten van de Rode Lijst uitgezet in Figuur 21.

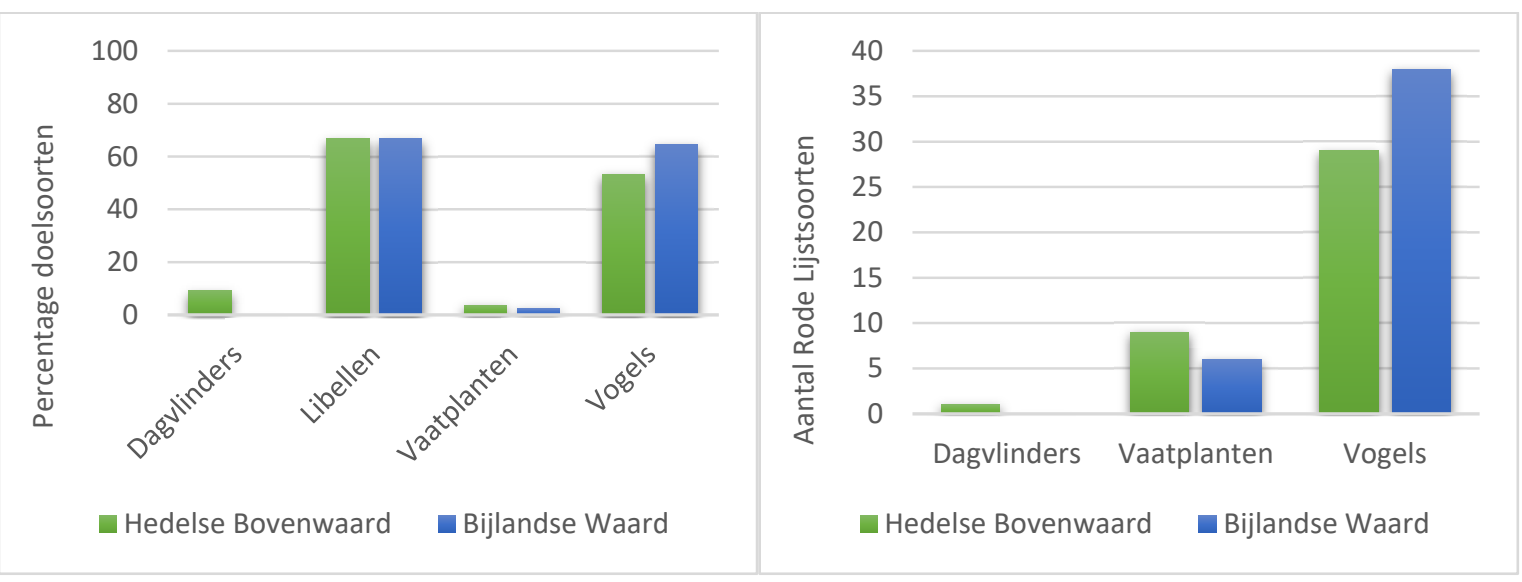

Figuur 21 Percentage doelsoorten en het aantal Rode Lijstsoorten dat voorkomt in de Hedelse Bovenwaard en de Bijlandse Waard.

\section{Berekening natuurpunten}

Op basis van natuurtypen en de waargenomen doelsoorten zijn voor beide locaties natuurpunten berekend (Tabel 6). Omdat de gebieden verschillen in leeftijd variëren de jaartallen, respectievelijk Hedelse Bovenwaard vanaf 1999 en de Bijlandse Waard vanaf 2007. De weegfactor is bepaald aan de hand van de huidige natuurdoeltypen en niet vanuit het streefbeeld (dat was gelijk voor beide gebieden). Door de ontwikkeling van de gebieden wordt de Hedelse Bovenwaard gedomineerd door nat schraalgrasland en de Bijland door rivierboslandschap.

Tabel 6 Het totaalaantal naturpunten berekend aan de hand van alle doelsoorten van het rivierengebied en het voorkomen daarvan in de Hedelse Bovenwaard en de Bijlandse Waard.

\begin{tabular}{|c|c|c|c|c|c|c|c|}
\hline & Hedelse Bovenwaard & & & & Bijlandse Waard & & \\
\hline Soortengroep & Soorten in referentielijst & Aantal soorten & Score & Soortengroep & Soorten in referentielijst & Aantal soorten & Score \\
\hline Dagvinders & 11 & 1 & 0,09 & Dagvlinders & 11 & 0 & 0,00 \\
\hline Libellen & 3 & 2 & 0,67 & Libellen & 3 & 2 & 0,67 \\
\hline Vaatplanten & 166 & 6 & 0,04 & Vaatplanten & 166 & 4 & 0,02 \\
\hline Vogels & 45 & 24 & 0,53 & Vogels & 45 & 29 & 0,64 \\
\hline Kwaliteit & & & 0,33 & Kwaliteit & & & 0,33 \\
\hline Oppervlakte (Ha) & & & 60 & Oppervlakte (Ha) & & & 64 \\
\hline Weegfactor & & & 1,8 & Weegfactor & & & 1,1 \\
\hline Natuurpunten & & & 35,83 & Natuurpunten & & & 23,50 \\
\hline
\end{tabular}


De input voor de berekende natuurpunten is voor beide gebieden aan de hand van de voorkomende doelsoorten en oppervlakte nagenoeg gelijk. De weegfactor is afwijkend door de huidige natuurdoeltypen en heeft een belangrijke bijdrage in de eindscore van de natuurpunten (zie Tabel 2 in $\S 3.2 .2$ ). De berekening houdt echter geen rekening met soorten die over de jaren zouden kunnen verdwijnen (zoals de kwartelkoning). Aan de hand van de doelsoorten van het rivierengebied volgens Jaspers (2017) zijn de natuurpunten per tijdvak van vijf jaar bepaald. Hiervoor zijn voor de verschillende natuurdoeltypen de punten berekend en bij elkaar opgeteld (Van de Put, 2017). Figuur 22 laat een positieve trend zien voor de onderzochte gebieden. De sterke stijging in de eerste vijf jaar wordt vermoedelijk veroorzaakt door het ontbreken van gegevens in de NDFF. In deze periode werd er veel afgegraven en zijn dit soort locaties vaak ontoegankelijk voor publiek. Het aantal waarnemingen is echter toegenomen in de tijd en laat de laatste vijftien jaar nog steeds een stijging in natuurpunten zien.

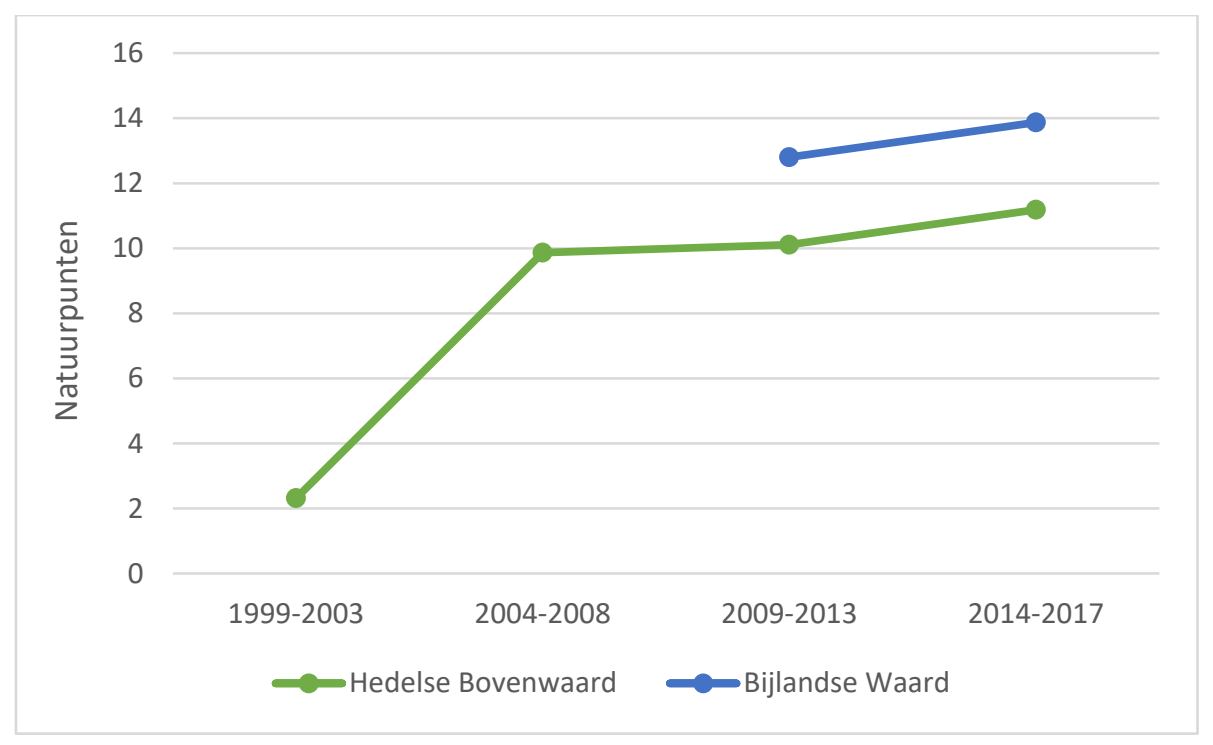

Figuur 22 Berekende natuurpunten per 5 jaar voor de Hedelse Bovenwaard en Bijlandse Waard.

\section{Conclusie gebruik natuurpuntensysteem}

Het natuurpuntensysteem is een geaccepteerde methodiek om de natuurwaarde te berekenen. De methode is oorspronkelijk ontwikkeld voor grote, ruimtelijke projecten (met name bouw en infrastructuur) en gaat uit van een waarde op basis van soorten, oppervlakte en een weegfactor. Omdat in zand- en grindwinning meerdere natuurdoeltypen ontstaan (en worden nagestreefd), zou het gebruik hiervan moeten worden geoptimaliseerd. De Hedelse Bovenwaard en de Bijlandse Waard tonen een toename van biodiversiteit sinds de ontwikkeling vanuit oorspronkelijke landbouwgronden, waarbij de natuurwaarde nihil is. De berekening van natuurpunten in kortere tijdsperioden en de optelsom van verschillende berekeningen aan de hand van de natuurdoeltypen (meerdere weegfactoren) geeft een goed beeld van de ontwikkeling binnen de projectlocatie. Indien de monitoringsgegevens het toelaten, is het berekenen van natuurpunten over kortere tijdsintervallen dus te adviseren.

\subsection{Waterstandverlaging}

Projecten in het kader van rivierverruiming en winning worden over een lange periode uitgevoerd. De periode voordat er daadwerkelijk delfstoffen gewonnen worden, duurt minstens tien tot vijftien jaar (grof gemiddelde) voordat alle voorbereidingen zoals vergunningen, grondwerving, onderzoek etc. zijn afgerond. Vervolgens duurt het winningsproces ook nog enkele jaren. Hierdoor zijn eisen, inzichten en normen die betrekking hebben op de waterveiligheid, natuurontwikkeling en beleid in de loop der jaren veranderd. Hierdoor worden soms de huidige normen niet behaald, omdat de voorwaarden jaren geleden zijn vastgelegd. Andersom kan het ook voorkomen dat tijdens het proces allerlei maatregelen moeten worden genomen om aan de huidige normen te voldoen. 
'Ruimte voor de Rivier' werkt aan 34 samenhangende maatregelen langs de IJssel, de Nederrijn, de Lek, de Waal en het benedenstroomse deel van de Maas. De maatregelen die zijn getroffen, verschillen per locatie en zijn vaak maatwerk (Figuur 23).

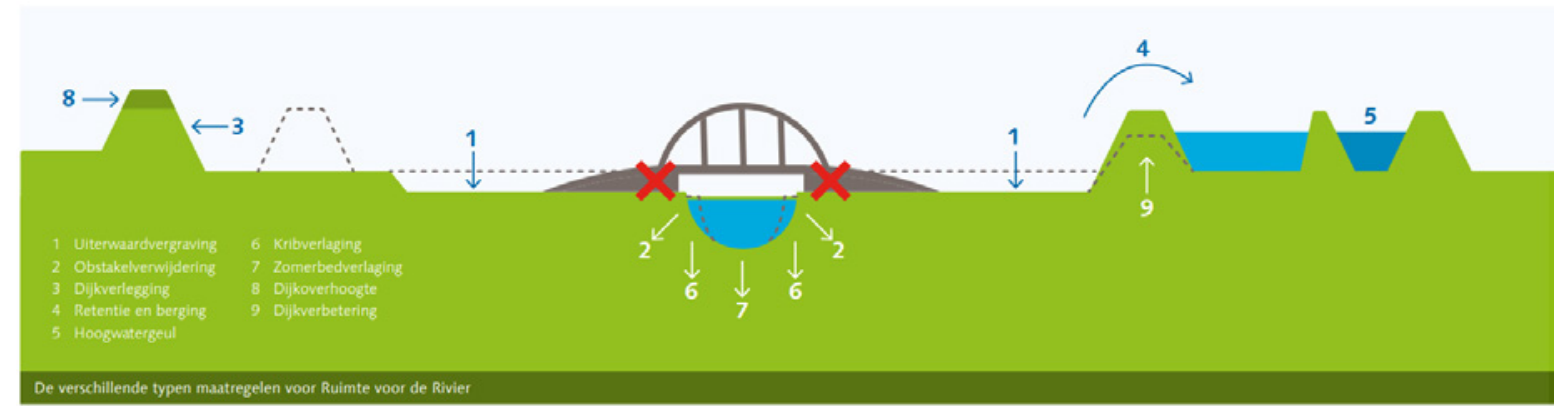

Figur 23 Verschillende maatregelen die bijdragen aan de rivierverruiming en waterstandverlaging zoals toegepast in 'Ruimte voor de Rivier' (Bron: www.ruimtevoorderivier.nl).

Tabel 7 geeft een overzicht van de opgegeven waterstandverlagingen (in centimeters). Niet van alle projecten zijn de waarden doorgegeven (met groen aangegeven). Via MER-rapportages zijn zo veel mogelijk beschikbare data getraceerd (in blauw aangegeven). Van vijf locaties zijn geen waarden gevonden. Waarschijnlijk hadden deze geen bijdrage aan de waterstandverlaging. Projecten met een groter traject, zoals Grensmaas, laten een fluctuatie in waarden zien. In de optelling is het gemiddelde genomen. In totaal zouden deze projecten $371 \mathrm{~cm}$ aan waterstandverlaging opleveren, verdeeld over de grote rivieren Maas, (Neder)rijn, IJssel en Waal.

Tabel 7 Overzicht van de gerealiseerde waterstandverlaging. In groen zijn de waarden aangegeven die door de bedrijven zijn doorgegeven. Blauwe waarden zijn afkomstig uit MER-rapportages en rode zijn afkomstig uit andere documenten en worden als niet betrouwbaar beschouwd.

\begin{tabular}{|c|c|c|c|}
\hline & Project & waterstandsverlaging $(\mathrm{cm})$ & Rivierlocatie \\
\hline 1 & Grensmaasproject & $80-120$ & Maas \\
\hline 2 & Stevol & $?$ & Maas \\
\hline 4 & Over de Maas & 15 & Maas \\
\hline 5 & Bijlandse waard & 7 & Rijn \\
\hline 8 & Lomm & 12 & Maas \\
\hline 9 & Kampergeul & 26 & Maas \\
\hline 10 & Raaijeinde-Grubbenvoorst & 2 & Maas \\
\hline 11 & Asseltse plassen & $0 ?$ & Maas \\
\hline 15 & Batenburg & 6 & Maas \\
\hline 16 & Marensche waard & 8 & Waal \\
\hline 17 & Hedelse bovenwaarden & $?$ & Maas \\
\hline 18 & Afferdense en Deestse waarden & 4,6 & Waal \\
\hline 19 & Willemspolder & ? & Waal \\
\hline 20 & Dreumelse waard & $0-6$ & Waal \\
\hline 21 & Randwijkse uiterwaarden & 2 & Rijn \\
\hline 22 & Tull en 't Waal & 8 & Lek \\
\hline 23 & Keent & 1,5 & Maas \\
\hline 24 & Millingerwaard & 9 & Waal \\
\hline
\end{tabular}


Het blijft heel lastig om deze getallen te vergelijken met andere 'Ruimte voor de Rivier'-projecten, harde cijfers ontbreken. Ron Agtersloot (Agtersloot Hydraulisch Advies) gaf aan dat de bijdrage van de delfstofwinners ongeveer $50 \%$ is (Agtersloot pers.med. 2017).

\subsection{Integrale samenhang}

De zand- en grindwinners spelen een belangrijke rol bij de ontwikkeling van nieuwe natuur en waterstandverlaging. In dit onderzoek zijn negen bedrijven geïnterviewd om de integrale aanpak en gemeenschappelijke dragers en actoren die een rol spelen bij biodiversiteit, waterstandsverlaging en de integrale samenhang tussen de verschillende bedrijven te achterhalen. Tabel 8 geeft een overzicht van de bezochte bedrijven en de contactpersonen die zijn geïnterviewd.

Tabel 8 Bezoeken aan delfstofwinbedrijven.

\begin{tabular}{llll} 
nr. & Bedrijf & Contactpersoon & Datum bezoek \\
\hline 1 & Consortium Grensmaas & Reinier de Poorter & 21 september 2017 \\
\hline 1 & Panheel BV/ Maasgrind & Reinier de Poorter & 21 september 2017 \\
\hline 2 & L'Ortye & Vivian L'Ortye & 21 september 2017 \\
\hline 3 & Nederzand & Herman van der Linden & 3 oktober 2017 \\
\hline 4 & Dekker grondstoffen & Richard van de Berg & 25 oktober 2017 \\
\hline 5 & Van Nieuwpoort & Koen van Aanholt & 4 oktober 2017 \\
\hline 6 & Teunesen & Jaap Deutekom & 11 oktober 2017 \\
\hline 8 & NIBA & Jerom Coppus & 4 oktober 2017 \\
\hline 9 & K3Delta & Mirjam Bottinga & 11 oktober 2017 \\
\hline
\end{tabular}

Nieuwe projecten roepen vaak weerstand op bij omwonenden. Het blijkt dat vooral in Limburg een negatief imago aan de delfstoffenindustrie kleeft. Dit is ontstaan door de grote primaire ontgrondingen die aan de Maas hebben plaatsgevonden, waardoor nu enorme diepe plassen zijn ontstaan zoals bij Roermond. Het beeld van burgers op ontgrondingen loopt nogal uiteen. In West-Nederland heeft men een onduidelijk beeld, terwijl langs de grote rivieren vrees is voor gaten graven en weer zo achterlaten. Dit leidde in het verleden nogal eens tot juridische geschillen. De weerstand vanuit de omgeving wordt door de bedrijven als een begrijpelijke situatie gezien en daarom gaat men tegenwoordig vanaf de eerste plannen al in gesprek met gemeente, omwonenden en belanghebbenden. Met een open houding worden tegenstanders uitgenodigd en gehoord. Deze mensen worden uitgenodigd om in een klankbordgroep mee te praten en in kansen en oplossingen te denken. Door de vorming van klankbordgroepen worden initiatieven en ideeën verzameld die geïntegreerd kunnen worden binnen de projecten. Dit levert soms direct nieuwe inzichten op, bijvoorbeeld door aanwijzingen op het gebied van cultuurhistorie. Meerdere partijen hebben aangegeven dat omwonenden het nu eerder jammer vinden als de projecten worden opgeleverd en de ontgronder het gebied weer verlaat. Hetgeen aangeeft dat er een goede relatie is ontstaan tussen ontgronder en de directbetrokkenen.

\subsubsection{Delfstofwinning en biodiversiteit}

In de open gesprekken werden vragen gesteld die betrekken hadden op de ontwikkeling van biodiversiteit in de afgeronde, lopende en toekomstige projecten. De volgende vragen kwamen terug in de interviews:

\section{Heeft deze organisatie baat bij natuur?}

Tijdens de visitaties bleef het enthousiasme niet onopgemerkt. Alle betrokken partijen zien de meerwaarde van de koppeling van natuurontwikkeling, 'Ruimte voor de rivier' met delfstofwinning en er is een groot belang bij het duurzaam achterlaten van het project. Projecten worden gezien als een referentiekader. 


\section{Welk percentage van de winning is nu bestemd als natuur?}

In alle projecten is nu natuur als eindbestemming opgenomen. De verdeling tussen natuur op het land en het aandeel van de diepe plassen die achterblijft, varieert. Doorgaans worden de gebieden geheel opnieuw ingericht en waar mogelijk ook diepe plassen verontdiept met rijkere landbouwgrond die als toplaag is verwijderd bij aanvang van het project. Hierdoor is een vast percentage niet te bepalen.

\section{Hoeveel natuur was er bij aanvang/hoe was de situatie voor de winning?}

Projectlocaties zijn meestal al in een veel eerdere fase aangekocht en al jaren in eigendom van de ontgronder. Gedurende deze periode zijn de gronden in de meeste gevallen verpacht aan lokale agrariërs, die maïs of tarwe verbouwen. In enkele gevallen vindt er veeteelt plaats. De gronden hebben daardoor doorgaans een zeer lage biodiversiteitswaarde voordat wordt gestart met de ontginning.

Figuur 24 laat zien dat ruim 85\% van de gronden vooraf landbouwpercelen waren. In een enkel geval werd de projectlocatie al gebruikt als recreatiegebied of was er een uitbreiding van een bestaande winlocatie.

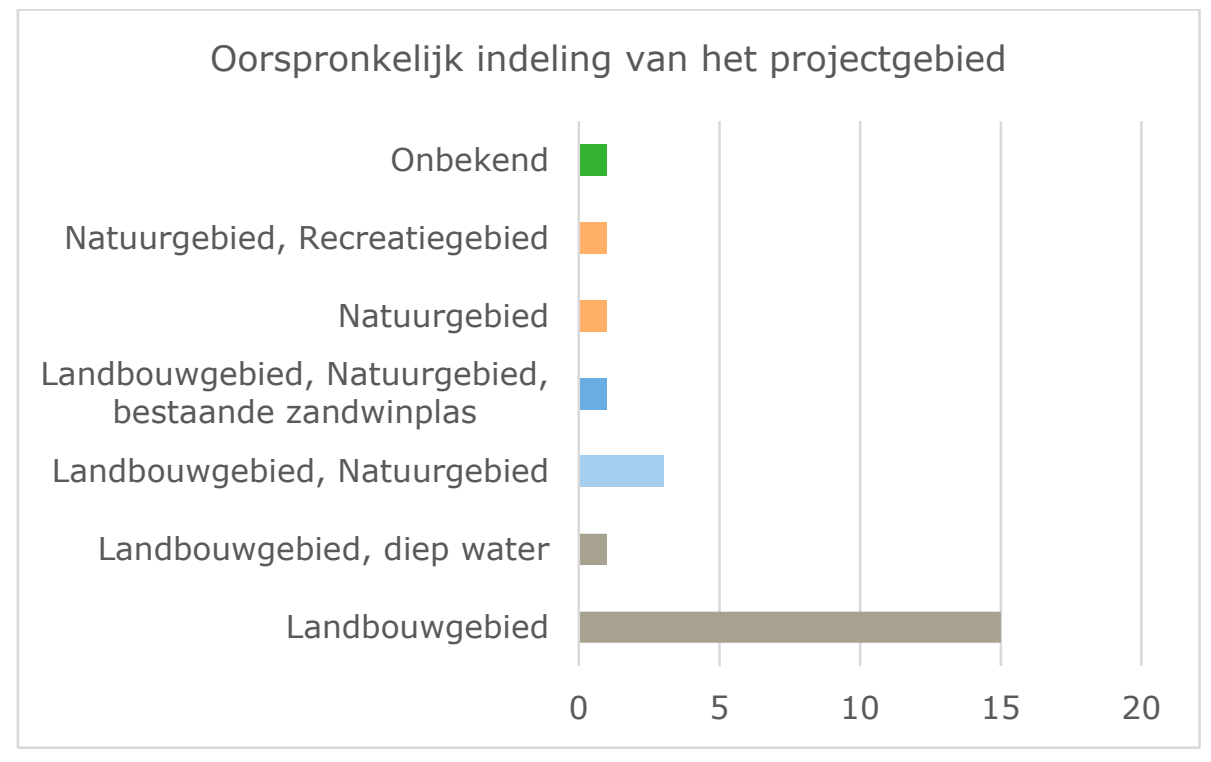

Figuur 24 Bestemming gebied voor de winning.

\section{Op welke wijze is er bijgedragen aan natuurontwikkelingen?}

$\mathrm{Bij}$ ieder project is opgevraagd hoeveel hectare nieuwe natuur is ontstaan (of als streefbeeld) na de ontgronding. Het antwoord op deze vraag bleek soms lastiger dan werd aangenomen, omdat gedurende periode dat het project plaatsvindt in sommige gevallen kleine wijzigingen hebben plaatsgevonden in de ruimtelijke ontwikkeling. Tabel 9 geeft een overzicht van de opgegeven waarden. Hierbij is in groen aangeduid welke waarden door de bedrijven zijn opgegeven. In blauw zijn oppervlakten opgenomen die uit MER-rapportages zijn gehaald en de rode getallen zijn van andere bronnen afkomstig. In totaal leveren de 28 projecten uit dit onderzoek bijna 3.400 hectare nieuwe natuur op. Ter vergelijking: in 2015 moet er ongeveer 7000 hectare nieuwe natuur zijn langs de grote rivieren. Rijkswaterstaat heeft dat afgesproken met het ministerie van Landbouw, Natuur en Voedselkwaliteit in het convenant 'Nadere uitwerking voor rivierengebied' (NURG) (Boonman, 2013). Deze selectie van 28 projecten alleen al levert de helft van de afgesproken doelstelling. 
Tabel 9 Overzicht van de opbrengst van nieuwe natuur (ha). In groen zijn de waarden aangegeven die door de bedrijven zijn doorgegeven. Blauwe waarden zijn afkomstig uit MER-rapportages en rood zijn afkomstig uit andere documenten en worden als niet betrouwbaar beschouwd.

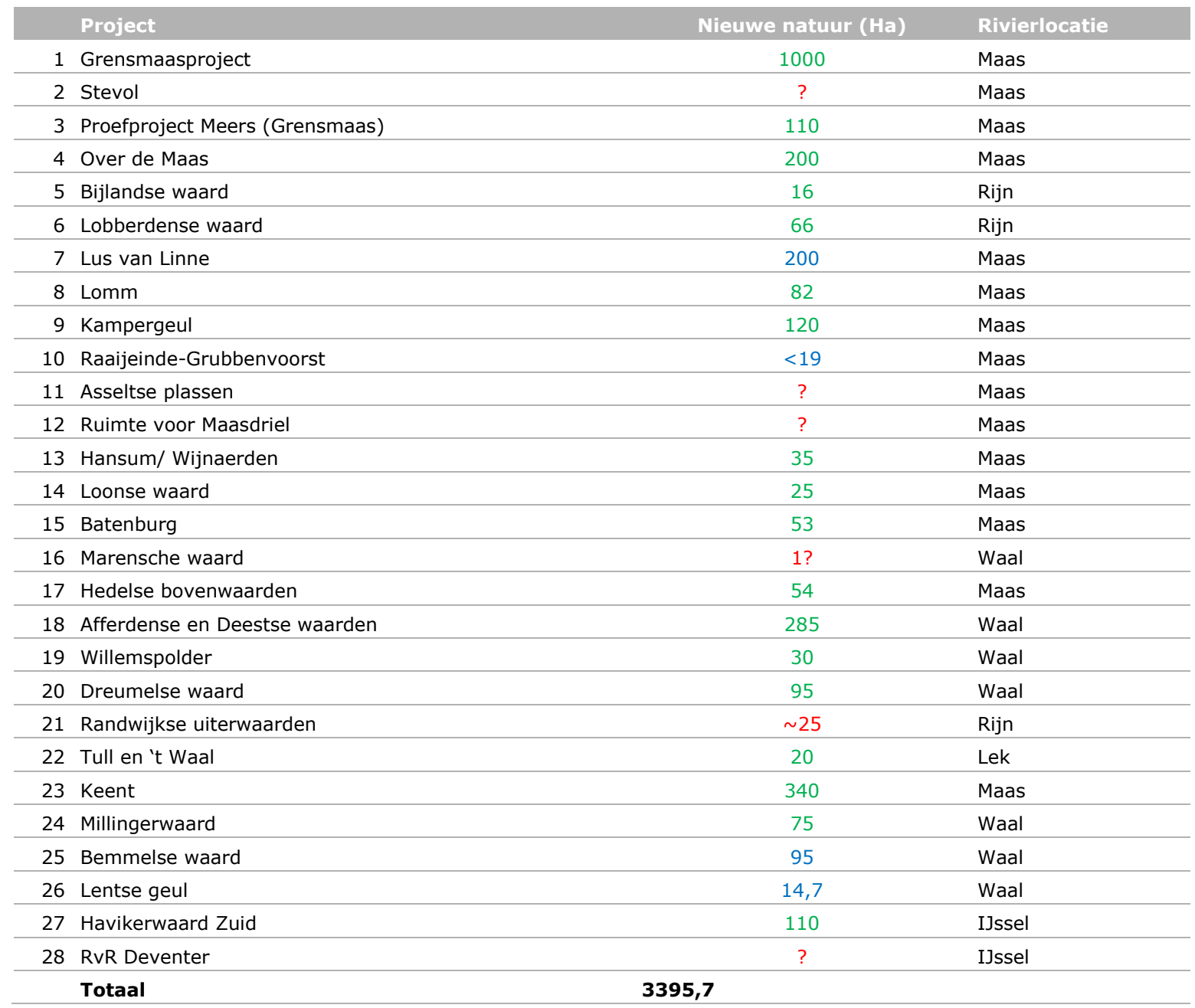

De gerealiseerde nieuwe natuur is in vrijwel alle gevallen overgedragen aan een terreinbeherende instantie. Uit de analyse van soorten die bij aanvang en na afloop aanwezig waren, kan worden bepaald of de streefbeelden behaald zijn (of worden).

\section{Werd er vooraf geïnventariseerd?}

Deze vraag werd doorgaans positief beantwoord. Voor de MER-studies werden quick-scans uitgevoerd, maar in veel gevallen worden ecologen of groene bureaus ingehuurd om een inventarisatie te maken van de aanwezige soorten in de projectgebieden. Gedurende de winningsperiode wordt er niet structureel monitoring uitgevoerd, maar waarnemingen van bijzondere soorten zijn meestal wel bekend bij de bedrijven.

Met wie werd samengewerkt $\mathbf{m}$.b.t. natuurdoelstellingen?

Omdat ontgronders geen natuurbeheerders zijn, wordt vrijwel altijd vanaf de planfase een terreinbeherende organisatie (TBO) zoals Staatsbosbeheer, Natuurmonumenten of een provinciaal Landschap betrokken bij de inrichtingsplannen, soms in samenwerking met stichting ARK of een landschapsbeheerder. Zo kunnen de gebieden na de oplevering worden overgedragen en sluit het gewenste beheer goed aan op de lokale omstandigheden. In een enkel geval blijven de gronden van de projectlocatie in particulier eigendom. Ook in dat geval vindt er vrijwel altijd kennisuitwisseling plaats, of wordt het beheer uitbesteed aan een TBO.

\section{Was er ruimte begroot voor natuur binnen het project?}

Dit bleek een irrelevante vraag, omdat natuurontwikkeling een voorwaarde is voor het initiëren van delfstofwinning. De delfstoffenindustrie noemt zich vaak de motor achter nieuwe natuur. Door de 
financiële middelen, maar ook door sterk omgevingsmanagement, draagt men bij aan nieuwe gebiedsinrichting. Natuur vormt hierin altijd een belangrijk en onoverkomelijk onderdeel.

\section{Welke habitats zijn hierdoor toegenomen? (Kwaliteit)}

Het is niet duidelijk welke typen habitat voornamelijk zijn toegenomen. Opvallend is wel dat er een streefbeeld ontstaat voor riviernatuur. Afhankelijk van de locaties wordt ingezet op houtwallen en ontwikkeling van zacht ooibos, maar de dominante vegetatie bestaat uit ruige graslanden die vaak beheerd worden met grote grazers.

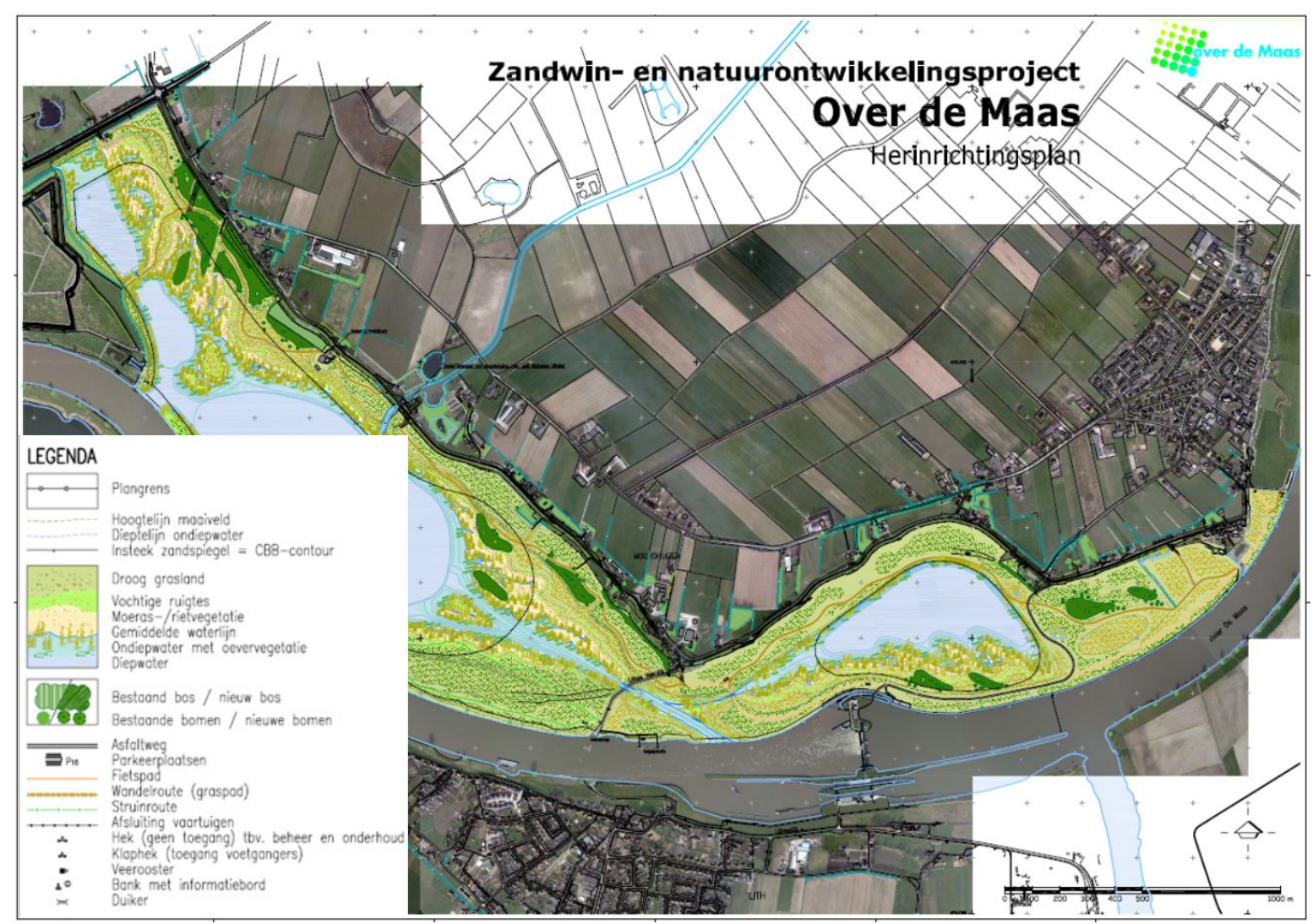

Figuur 25 Voorbeeld van een streefbeeld riviernatuur (herinrichtingsplan Over de Maas).

Figuur 25 laat een typisch streefbeeld voor riviernatuur zien. De dynamische elementen als rivierduin en moerasvorming passen vaak niet in het streefbeeld of zijn lastiger te realiseren. Ook de ontwikkeling naar stroomdalgraslanden blijft vaak achterwege. Vermoedelijk kiest men voor het nieuwe streefbeeld, omdat dit goedkoper in beheer is en inmiddels steeds meer geaccepteerd wordt als streefbeeld.

\section{Welke zeldzame/bedreigde soorten hebben hier vooral baat bij?}

Tijdens de interviews werden verschillende antwoorden gegeven op deze vraag. In de analyse op de biodiversiteitstoename is meer inzichtelijk welke soorten in algemene zin profiteren van het realiseren van nieuwe natuur. De lepelaar en de oeverzwaluw werden door de meeste bedrijven genoemd. Met name de oeverzwaluw maakt gebruik van zandige steile randen, die vaak voor deze soort worden aangelegd. De lepelaar is een broedvogel die in kolonies broedt en zelden in de projectgebieden. De vogels komen hier vooral voedsel zoeken. In een enkel geval werd de bever genoemd, deze soort neemt in aantallen toe langs het gehele rivierengebied en heeft baat bij de vorming van ooibos en water dat onder invloed staat van de rivier. Toch wordt de bever als vaandeldrager juist het meest genoemd. 


\section{Is $\mathbf{N 2 0 0 0}$ een probleem en hoe wordt daarmee omgegaan?}

De projectlocaties zijn vrijwel nooit aangewezen als Natura 2000-gebied en daarmee vormt dit zelden een probleem. Wel wordt door verschillende bedrijven de ganzenproblematiek aangegeven. Het foerageergebied van deze vogels is wettelijk beschermd. Omdat grauwe gans een toegenomen broedvogel is, zijn de vogels jaarrond aanwezig. Pragmatische oplossingen die zijn vernomen, betreffen de omvorming van graslanden naar agrarisch gebied. Maïs of tarwe gaat de vestiging van ganzen tegen en daarom worden deze graslanden verpacht tot het moment dat de werkzaamheden voor de delfstofwinning starten. Zo hoeft men geen rekening te houden met de ganzen.

Vooral bij de wat oudere projecten zijn de beheerplannen voor Natura 2000 pas tijdens het project geleverd. Zo kunnen aanpassingen (bijv. extra wensen t.a.v. rivierverruiming) ten opzichte van de instandhoudingsdoelen lastig zijn. Als voorbeeld kan een gebied zijn aangewezen voor bepaalde vissoorten (die er nu nog niet zitten). De tijdelijke vertroebeling van het water als gevolg van het grindwinnen is daarmee strijdig, het voorkomt in ieder geval de vestiging van vissen. In de praktijk blijft de uitvoering gewoon doorgaan en verandert deze niet.

Indien beschermde soorten zijn vastgesteld in de inventarisatie wordt doorgaans rekening gehouden met deze soorten door te werken met de gedragscode duurzaam winnen, waarin verwezen wordt naar de gedragscode flora en fauna. Inrichtingsplannen worden dan ook vaak aangepast om deze soorten, zoals fonteinkruiden of rugstreeppadden, te behouden. Ook werd aangegeven dat stroomdalgraslanden in N2000 nog onderbelicht zijn en dat hiervoor meer aandacht zou moeten komen in herstel en ontwikkeling van dit kenmerkende habitattype voor riviersystemen.

Natuurwetgeving is volgens enkele deelnemers te strikt. Door maatregelen te nemen, kunnen beschermde soorten worden behouden of toenemen. Echter, soms neemt het aantal beschermde dieren zodanig toe, dat dit nu ineens haaks op de uitvoering van het project komt te staan. Zo kan een toename van dassen of steenuilen ervoor zorgen dat er extra maatregelen moeten worden genomen om deze (nieuwe) dieren te compenseren of te mitigeren. Het aanvragen van een ontheffing tijdelijke natuur (recent ook als gedragscode te gebruiken) zou een oplossing zijn voor dit 'probleem'. Echter kiezen veel ontgronders voor 'eigen' oplossingen door potentieel habitat zo snel mogelijk ongeschikt te maken. Geen van de negen bedrijven gaf aan van de regeling Tijdelijke Natuur gebruik te maken. Overigens is er altijd goed overleg tussen de bedrijven en ecologen om naar oplossingen te zoeken.

Maar ook de mogelijke aanwezigheid van beschermde soorten die volgens de Nationale Databank Flora en Fauna (NDFF) ooit in het gebied gesignaleerd zijn, vereist soms specifiek onderzoek naar deze soort(en), terwijl op voorhand duidelijk is dat het vereiste habitat al verdwenen is. Zo kunnen hagedissen op de kaart staan, terwijl hun leefgebied al is verdwenen.

De PAS wordt eigenlijk als bezwaarlijker ervaren, omdat de tijdelijke stikstofuitstoot door uitvoering van het werk een tijdelijke verhoging oplevert t.a.v. het achtergrondniveau. Het argument van landbouwgrond verwijderen (en daarmee een structurele verbetering van de stikstofbalans realiseren), mag niet worden gesaldeerd in de uiteindelijke berekening in Aerius. De oplossingen hiervoor lopen nogal uiteen, van overschakelen naar duurzame energie, spreiding in de tijd of inzetten van ander materieel. Anderen pleiten voor meer ruimte binnen de PAS, mogelijk door te opteren voor gebiedsontwikkeling en waterstandverlaging. Figuur 25 laat zien dat ruim $60 \%$ (14 van de 23 ) geen hinder heeft van Natura 2000-doelstellingen. 


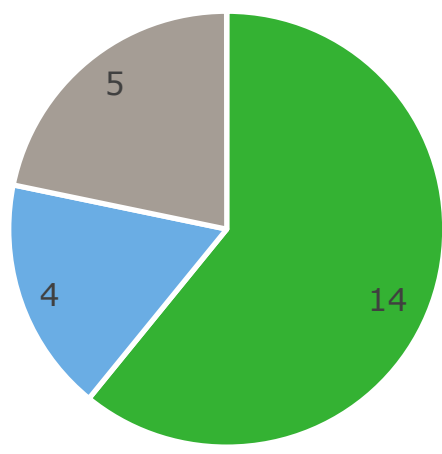

- Nee - Ja $=$ Onbekend

Figuur 26 Verdeling van de ervaringen met de PAS $(n=23)$.

\section{Hoe is het draagvlak voor natuur binnen de organisatie?}

$\mathrm{Er}$ is geen eenduidig antwoord op deze vraag te geven. Bij enkele bedrijven wordt al vanaf de oprichting rekening gehouden met omgeving en natuur. Terwijl in andere organisaties de drijfveer vooral afhangt van een zeer gemotiveerde en enthousiaste medewerker. Natuur is, naast het morele besef, ook bruikbaar en nodig om het ontstane negatieve imago van deze industrie op te poetsen. Natuur wordt daarom wel als belangrijk ervaren, maar ook omdat dit vereist wordt. Het beleid en het draagvlak veranderen daarmee wel door de jaren. Projecten met ruimtelijke meerwaarde spelen een belangrijkere rol. Maar bij delfstofwinning ligt de focus in eerste instantie toch op de productie en niet om de nevendoelen, zoals het realiseren van natuur. Daarnaast wordt de natuurcomponent vaak neergelegd als op te pakken taak bij een opgericht consortium of bij de natuurorganisatie waarmee wordt samengewerkt.

Veel bedrijven schenken aandacht aan de natuur die ontstaat op het eigen terrein, maar misschien nog wel te weinig (naar eigen zeggen). Er zijn liefhebbers genoeg die natuurontwikkeling (en cultuurhistorie en archeologie) opmerken. Een fractie van het personeel komt hiermee in aanraking en raakt enthousiast (en verbaasd!). Maar het grootste deel van de medewerkers is chauffeur en die heeft meestal meer civiele interesse!

\section{Is er samenwerking of kennisuitwisseling met concullega's?}

De industrie is er zich van bewust dat kennis gedeeld moet worden en dat er op het gebied van duurzame ontwikkelingen samenwerkingen gerealiseerd moeten worden. Er zijn wel bijeenkomsten waar kennis wordt gedeeld; deze kennis gaat in de praktijk maar beperkt over de ontwikkeling van biodiversiteit. Maar er is niet een echte strategie op dit vlak. Het opzetten van consortia bevordert deze samenwerking en leidt ook tot kennisdeling.

Men ziet een wirwar aan regels, die soms ook geen of nauwelijks een doel hebben. Zo moet bijvoorbeeld chloride worden gemeten in het water, terwijl dat er nauwelijks inzit (dit is alleen nodig voor kustwater, maar de regel geldt algemeen). Het is een verzwaring om met de regels om te gaan, maar men ziet de ontwikkeling en eindbeelden positief in. Samenwerkingen met andere stakeholders gaat daarentegen heel goed. Men weet van elkaars belangen en men weet elkaar goed te vinden. Klankbordgroepen en openstellingen dragen bij aan kennisdeling en informeren van de directe omgeving. 


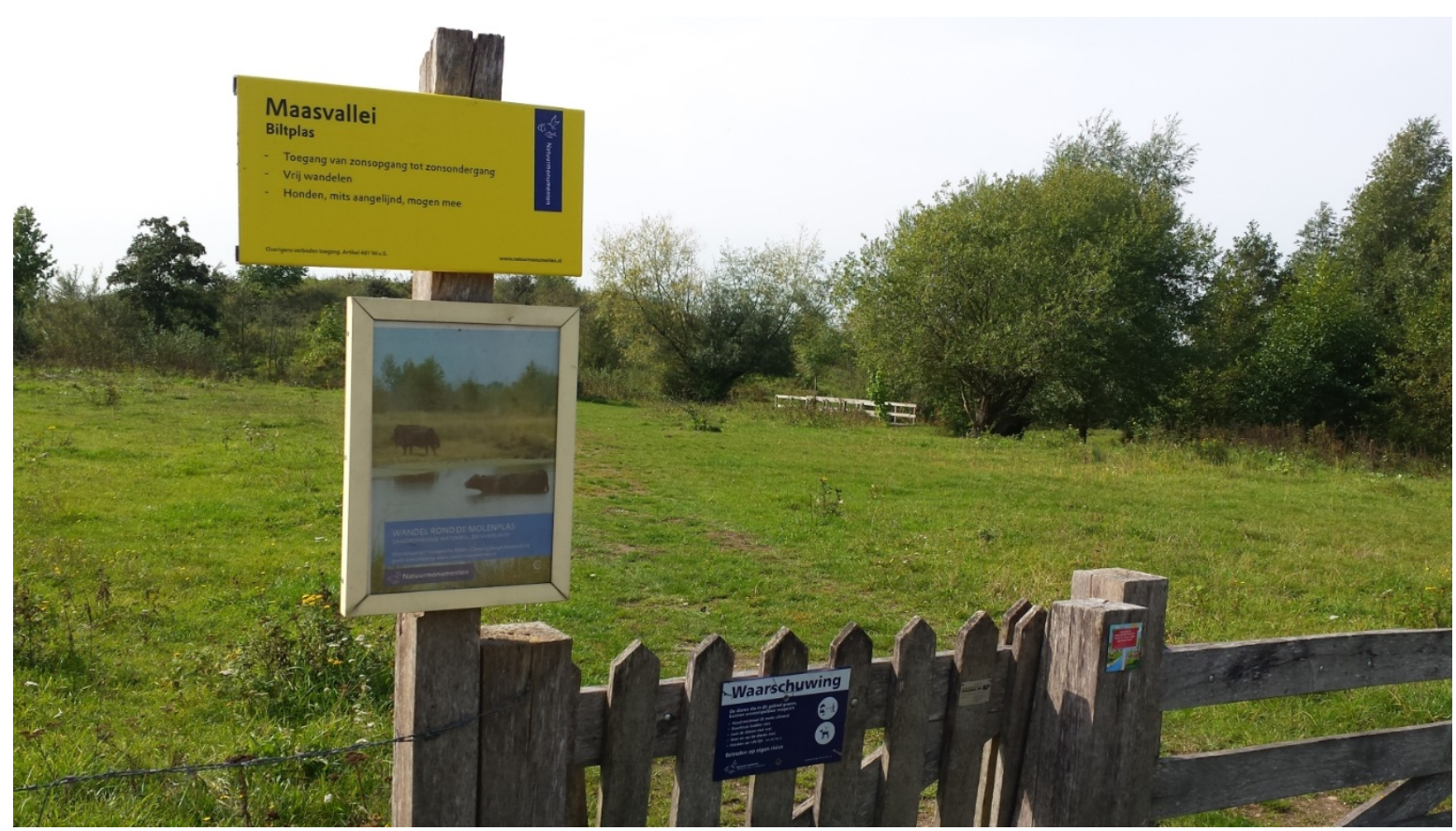

Foto 10 Voormalig wingebied Biltplas (Maasvallei), nu beheerd door Natuurmonumenten (Foto: Friso van der Zee).

\section{Hoe is biodiversiteit tot op heden gewaardeerd en heeft dit economische waarde opgebracht? Ofwel, is er een aanwijsbare winst aan te duiden?}

De opbrengsten van ontgrondingen die buiten de industrie liggen zijn lastig te bepalen. De inrichting en realisatie van nieuwe natuur kunnen soms worden gekoppeld aan recreatieve doelstellingen. Deze zijn overigens makkelijker te realiseren bij binnendijkse ontgrondingen. Bij de inrichting van een recreatiegebied kan er nog wel eens een horecagelegenheid worden geëxploiteerd. Bij het project Grensmaas ziet men een lichte toename van toeristen in het gebied, maar de inkomsten die deze mensen moeten genereren, komen vaak niet direct terug in het gebied zelf. Indien een externe partij (bijvoorbeeld een exploitant of projectontwikkelaar) een vergunningaanvraag doet voor een project waarbij een diepe plas in het ruimtelijke plan is opgenomen, blijkt het verkrijgen van een vergunning vaak eenvoudiger. Dit kan economisch voordelig zijn voor de ontgronder, die deze ontwikkeling kan mee koppelen, maar die ook producten kan winnen.

Omdat de projectgebieden vaak worden overgedragen aan terreinbeheerders en daarmee de toegankelijkheid van het gebied ook vergroot wordt voor het publiek, krijgen juist de terreinbeherende organisaties de meeste waardering voor de gebieden. In een enkel geval wordt er een informatiecentrum geopend, zoals bij Ohé en Laak (Grensmaas). Anderzijds kan er nog weleens economisch voordeel worden behaald door aanpassingen op civiel vlak. Door bruggen langer of breder te maken dan oorspronkelijk gepland, kan meer rivierverlaging worden bereikt met een minimale inspanning. Hierdoor worden kosten bespaard doordat anders op andere plaatsen extra maatregelen getroffen hadden moeten worden. Ook met slimme oplossingen (door laadwallen te benutten of om te vormen naar nieuwe bestemmingen) kunnen kosten, maar ook landschappelijke ingrepen worden bespaard.

\subsubsection{Delfstofwinning en waterveiligheid}

In de gesprekken werden vragen gesteld die betrekking hadden op de bijdrage aan de waterstandverlaging en de veiligheid van rivieren. De volgende vragen kwamen terug in de interviews:

\section{Waar heeft zand- en grindwinning een rol gespeeld bij het realiseren van rivier-/water- veiligheid doelstelling?}

Hoewel waterstandverlaging meestal geen doelstelling is, dragen vrijwel alle projecten bij aan de rivierverruiming. Mogelijk niet altijd in harde centimeters waterstandverlaging, maar dan wel voor de 
doorstroming van een gebied. Berekening van waterstandverlaging vindt plaats met volgroeide vegetatie. Zo werd een voorbeeld gegeven van een project waar enkele centimeters waterstandverlaging werden bereikt, maar door de ontwikkeling van natuur is deze waterstandverlaging tenietgedaan. Er is hierdoor echter wel nieuwe natuur ontstaan, zonder consequenties voor de waterveiligheid.

Je kunt de verlaging van afzonderlijke projecten niet simpelweg bij elkaar op tellen. Maar je zou ze wel kunnen vergelijken met de verlaging die gerealiseerd wordt in het kader van 'Ruimte voor de rivier' of een publiek- versus een privaatinitiatief te vergelijken. Het verschil is dat de private initiatieven de overheid nauwelijks geld kosten. De sector erkent dat beide initiatieven goed zijn. De overheid heeft de toewijzende rol (zelf het initiatief) en soms de toetsende rol (bij particulier initiatief). Het is dan ook bijzonder dat de zand- en grindwinnende industrie zelf initieert, ontwerpt, ontwikkelt en financiert om te realiseren. Dat zou de branche moeten blijven uitdragen.

\section{Hoeveel $\mathbf{~ c m}$ waterstandverlaging is gerealiseerd door middel van delfstofwinning?} Waterstandverlaging wordt tegenwoordig meer uitgedrukt in de overstromingskans. De bedrijven geven aan deze kans te willen vergroten van 1x per 1250 jaar naar 1x per 3000 jaar. Echter worden de projecten nog steeds in centimeters waterstandverlaging aangeduid. Bij ieder project is opgevraagd hoeveel centimeter waterstandverlaging is of zal ontstaan na de ontgronding. In sommige gevallen zijn de waarden veranderd in de tijd, omdat het project op het riviertraject wordt beïnvloed door een ander (rivierverruimings)project. Soms zijn de ruimtelijke ingrepen veranderd waardoor de eindwaarde ook wordt beïnvloed. Zo kan een brug met een bredere doorgang die later is aangepast direct gevolgen hebben voor de overstromingskans of het aantal centimeters verlaging. Tabel 7 in $\S 4.2$ geeft een overzicht van de opgegeven waarden in centimeters. In totaal leveren de 28 projecten uit dit onderzoek ruim 370 centimeter waterstandverlaging op.

\section{Waar kan delfstofwinning in de toekomst een vanzelfsprekender rol krijgen in het kader van het Delta Programma en wat moet hiervoor gebeuren?}

De industrie vindt dat de branche een professionele gesprekspartner is en een duidelijkere rol zou moeten hebben bij de planvorming in het deltaprogramma. Op dit moment leeft het beeld dat de overheid te zwart-wit denkt en meer aan de markt moet overlaten, die vervolgens beter kan acteren op de behoefte van de producten en minder afhankelijk wordt van aanbestedingstrajecten. Daarbij komt dat de belangen van directbetrokkenen te weinig worden gewogen. Het historisch imago dat ontgronders alleen maar diepe gaten maken, kleeft nog en daar is lastig van los te komen. Mogelijk dat handhavers daarom ook zo precies zijn in het volgen van de vergunningen. De natuurwetgeving richt zich te veel op beheer en onderhoud en helaas niet op de dynamische projecten. Hierdoor moeten steeds obstakels worden overwonnen.

De industrie kan een vanzelfsprekender rol krijgen in het kader van het Delta Programma door meer initiatieven te laten zien waarbij wordt samengewerkt met lokale overheden, omwonenden en natuurorganisaties. De keerzijde is wel dat processen vooraf langdurig zijn en veel tijd kosten. Dan is de rol voor gemeenten belangrijk dat die 'de kar trekken' met RWS en provincies. Het is wel interessant om op tijd aan tafel te zitten, maar de belangen van producten moet wel worden meegewogen, waardoor de ontgronders voor de uitwerking op een lager niveau aan tafel zitten.

\section{Waar liggen de kansen om waterveiligheid optimaal te koppelen aan biodiversiteit?} De noodzaak voor waterveiligheid en rivierverruiming zijn meestal makkelijker uit te leggen dan de ontwikkeling van nieuwe natuur. Zeker als er ervaring is van omwonenden met hoog water is. De laatste jaren neemt het draagvlak wat af, want deze dreiging wordt minder. Landbouwgronden verdwijnen en dat ligt lokaal toch gevoelig. Op hoger abstractieniveau heeft natuur wel meerwaarde.

De betrokken partijen hebben belang bij het duurzaam achterlaten van het project. Het wordt gezien als een referentiekader, daarom is er ook een voorkeur voor een professionele landelijke beheerder voor de continuïteit en een lokale partij voor dagelijks beheer en toezicht. Het doel is een gebied achter te laten zonder rasters dat in verbinding staat met de andere projecten langs de Waal (en Rijn). 


\subsubsection{Samenhang en integratie projecten delfstofwinning}

In de gesprekken werden ook vragen gesteld die betrekking hadden op de integrale aanpak van de bedrijven. Het doel van het onderzoek is te achterhalen welke (f)actoren een rol spelen in het gemeenschappelijk belang en het uitdragen van de ontwikkeling van biodiversiteit en waterstandverlaging. De volgende vragen kwamen terug in de interviews:

\section{Hoe kan meer samenhang tussen de individuele projecten van delfstofwinning bereikt worden op het thema biodiversiteit en Natura 2000? En hoe kan bereikt worden dat delfstofwinners hier enthousiast en vrijwillig aan mee gaan werken?}

Dat is lastig, omdat het enthousiasme voor natuur (of archeologie) doorgaans door enkelen wordt (uit)gedragen. Er wordt dan aandacht geschonken aan de natuur die ontstaat op het eigen terrein. Men erkent dat nieuwe ontwikkelingen op het gebied van natuur beter benut kunnen worden naar de buitenwereld. Er zijn vaak liefhebbers genoeg die het wel opmerken, maar dan blijft het bedrijf in dit opzicht te bescheiden.

Het inzetten van een consortium zorgt voor een gezamenlijke aanpak en voor het uitdragen van informatie. Ontwikkelingen op het gebied van natuur of archeologie worden dan meestal overgelaten aan het consortium. De capaciteit binnen het consortium is vaak ontoereikend om een goede exposure te realiseren. De bedrijven zijn bovenal gericht op de productie van zand en grind en de meeste aandacht gaat uit naar een goed omgevingsmanagement. Hierdoor zijn belangen in het kader van biodiversiteit minder prioritair. Er is weinig kennisdeling als het gaat om overeenkomstige projecten die dicht bij elkaar liggen. De focus ligt vaak op 'gemiddelde' natuur gericht op de gewone mens, dicht bij huis met recreatiemogelijkheden voor mens (laagdrempelig) en hond.

Meer uitdragen van de positieve resultaten vindt vrijwel iedereen belangrijk. Het verhaal over natuurontwikkeling en de aanwezigheid van bijzonderheden kan wellicht beter door derden verteld worden. Nu komt deze informatie vooral via natuurorganisaties en vrijwilligers binnen. Een effect zou kunnen zijn dat de insteek van discussies van notoire tegenstanders een wending krijgt. De sector stelt zich bescheiden op als het gaat over de grote drijfveer achter het ontstaan van nieuwe natuur. Meer voorbeelden en publicaties buiten het eigen werkveld zouden een waardevolle toevoeging kunnen zijn om meer saamhorigheid te ontwikkelen. Voor het bij elkaar brengen van kennis ziet men vooral de rol weggelegd bij de brancheorganisatie Cascade.

\section{Welke methodieken ken je om natuur te waarderen?}

Deze vraag werd als moeilijk ervaren. De meeste mensen wisten geen methodiek te noemen. De uitzondering daarop was het natuurpuntensysteem. Deze methode is voor enkele projecten getoetst en daardoor bekend bij de bedrijven van de getoetste projecten.

\section{Welke verbindende factor is van toepassing om de individuele winlocaties van een gezamenlijke strategie te voorzien?}

Brainstorm met enthousiastelingen die de belangenverstrengeling opzijzetten om een gezamenlijke strategie te ontwikkelen. Transparantie en kennisdeling zijn cruciaal om een strategie te ontwikkelen. Hierbij zou de input van stakeholders buiten de delfstoffenindustrie zeer waardevol zijn.

Natuurorganisaties, belangenverenigingen etc. denken graag mee en benaderen vaak vanuit een ander perspectief.

\section{Hoe reageert de omgeving op de natuurontwikkeling?}

Voordat de projecten starten, is er vaak weerstand uit de omgeving. Door de mensen te betrekken in de klankbordgroepen en hun ideeën mee te wegen in de inrichtingsplannen worden spanningen weggenomen. Bij veel projecten betreurt de omgeving het als de projecten worden opgeleverd en de winactiviteiten verdwijnen. Met name de sociale binding met de gemeenschap, het bedrijf of consortium en de belanghebbenden wordt als zeer waardevol ervaren. Natuurontwikkeling is daarvan een bijproduct. Als er meer natuur komt, vooral als je daar ook gebruik van mag maken, is dat positief. Het zijn eerder natuurliefhebbers die de ontwikkeling van natuur bijhouden. 


\section{Zijn er samenwerkingen met natuurorganisaties?}

Deze vraag is reeds beantwoord onder het thema biodiversiteit. Natuur is gekoppeld aan ontgrondingsprojecten en daarvoor worden ecologen ingeschakeld voor advies en terreinbeherende organisaties ingeschakeld voor beheer. Indien de terreinen in eigendom en eigen beheer blijven, is er meestal samenwerking met lokale natuurorganisaties over inrichting, monitoring en beheer.

\section{Waar zou de branche zich mee kunnen profileren als het gaat om natuur?}

$\mathrm{Er}$ is een aantal duidelijke antwoorden uit de interviews gekomen:

- De zand- en grindwinnende industrie maakt nieuwe natuurgebieden: zonder deze ontwikkeling zouden TBO's vrijwel geen nieuwe terreinen in het rivierengebied kunnen ontwikkelen.

- Bedrijven zijn zelf een terreinbeherende organisatie als ze terreinen na afloop in eigendom zouden houden. Dit gebeurt tot nu toe zelden, maar kan ervoor zorgen dat de waardering voor biodiversiteit meer bij de sector zelf terecht komt. Ook zal de inhoudelijke kennis over natuurbeheer dan toenemen.

- De ontwikkeling, met name het voorkomen van bijzondere soorten, zou naar het publiek beter moeten worden uitgedragen.

- Men zou de gebieden een hogere natuurbelevingswaarde kunnen meegeven, bijvoorbeeld in struinnatuur of educatie.

- Andere framing. Gebiedsontwikkeling of nieuw struingebied klinkt beter dan ontgronden.

\section{Welke soort zou je als vaandeldrager willen voordragen?}

Op de vraag welke soort als vaandeldrager kan dienen voor de zand- en grindwinners kwamen uiteenlopende reacties (Figuur 27). De bever scoorde duidelijk het hoogste met tien noteringen (38\%). Blauwborst, Otter scoren tweemaal in de lijst en de Karekiet (waarschijnlijk bedoelt men de grote karekiet) zelfs driemaal. Daarnaast werd ook driemaal naar riviergebonden natuur verwezen en in twee gevallen was de soort niet duidelijk, omdat het project nog niet af is.

Andere soorten die eenmaal werden benoemd, zijn: aalscholver, bruine kiekendief, fonteinkruiden, ganzen, gele kwikstaart, ijsvogel, kamsalamander, kievit, kleine watersalamander, lepelaar, oeverzwaluw, poelkikkers, raaf, roerdomp, tapuit, visdief en vleermuizen.

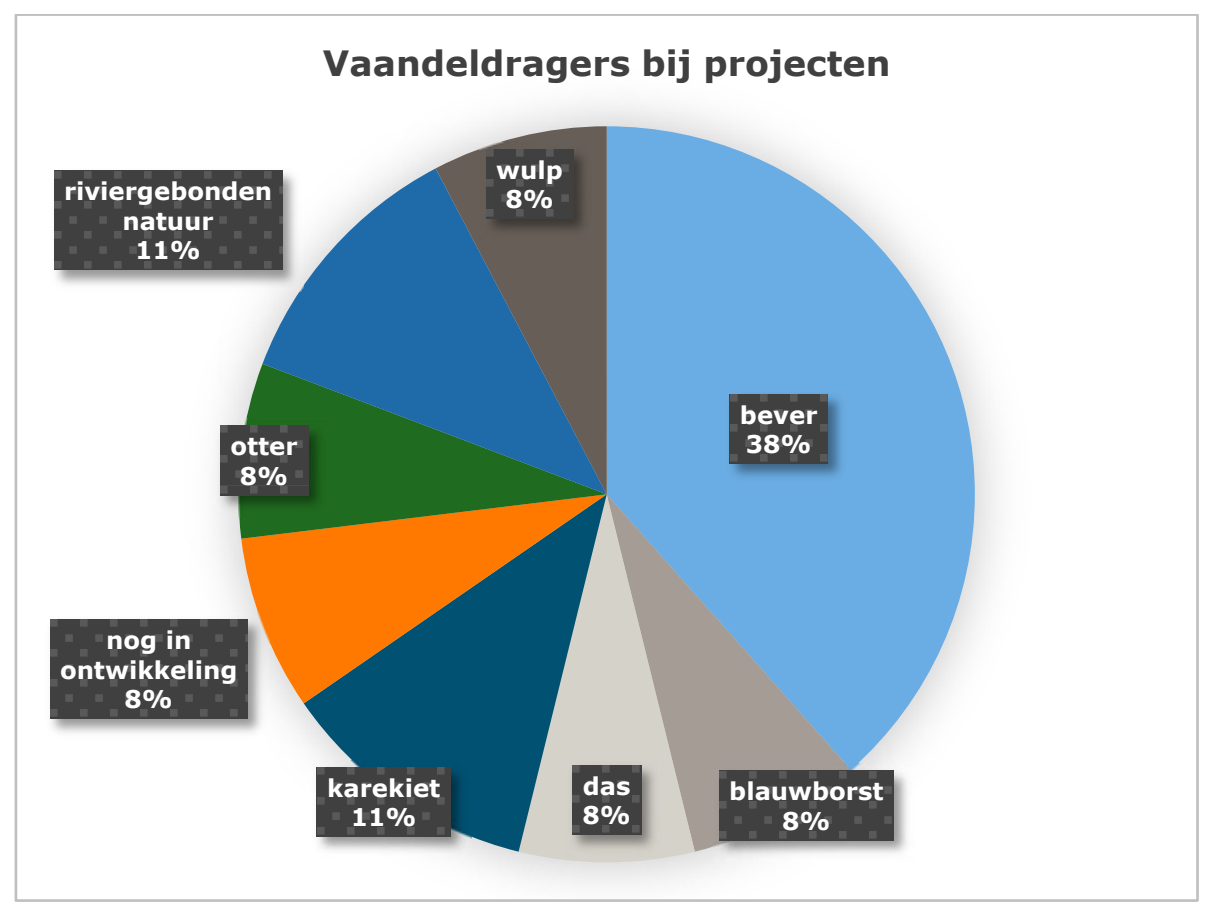

Figuur 27 Verdeling van aangegeven soorten die als vaandeldrager kunnen optreden voor de zanden grindwinnende industrie langs de grote rivieren. 
Van de genoemde soorten zijn fonteinkruiden wellicht het minst bekend. Vleermuizen is een gehele soortgroep, hierbij zou men voor watervleermuis, meervleermuis of een andere soort kunnen kiezen. Onder ganzen vallen ook meerdere soorten. De grauwe gans (en ook wel de brandgans) is een broedvogel van het rivierengebied. Ganzen worden door sommige bedrijven en agrariërs soms echter als vervelend ervaren vanwege de beschermingsstatus, waardoor dit geen handige vaandeldrager zal zijn. De raaf is een soort die zich heeft uitgebreid in Nederland, maar niet tot de typische rivierfauna behoort. De bever is wel een geschikte kandidaat, omdat deze soort zich uitbreidt in het rivierengebied, daar ook een kensoort is en omdat ook meerdere mensen deze soort hebben aangedragen, is er ook een breder draagvlak voor. Daarbij komt dat de bever een hoge aaibaarheidsfactor heeft.

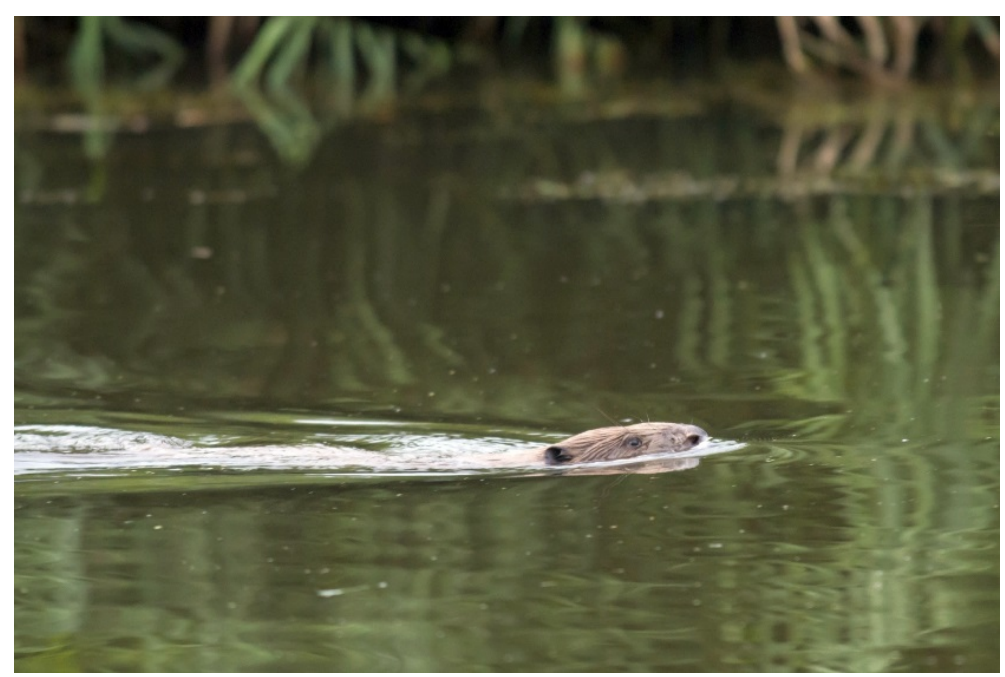

Foto 11

Bever (Foto: Hugh Jansman). 


\section{$5 \quad$ Discussie en Conclusies}

\subsection{Biodiversiteit}

\subsubsection{Natuurpuntensysteem \& NDFF-gegevens}

Het vaststellen van de toename in biodiversiteit is gedaan m.b.v. een aangepaste versie van het natuurpuntensysteem. Kenmerkend daarvoor is dat gerekend wordt 1) met de aan- of afwezigheid van referentiesoorten inclusief een weging voor habitattypen en 2) dat de gegevens afkomstig zijn uit de NDFF en grotendeels verzameld zijn door vrijwilligers. Is dit een betrouwbare methode om verschillen in biodiversiteit vast te stellen?

Dat het natuurpuntensysteem werkt met het aandeel referentiesoorten van een habitattype is een logische en voor dit project ook bruikbare keuze. Hoe meer referentiesoorten aanwezig zijn, hoe vollediger het ecosysteem en hoe hoger de score. En bepaald habitat is meer bedreigd dan andere en hebben landelijk gezien een hogere prioriteit, dus dat doelsoorten uit deze habitat zwaarder meetellen in de score, vinden wij ook een objectieve methode voor het beoordelen van de gebieden van delfstofwinners.

Het werken met gegevens uit de NDFF heeft als grote voordeel dat er van vrijwel elk terrein in Nederland natuurgegevens beschikbaar zijn uit allerlei perioden en van verschillende soortgroepen. De vrijwilligers die veel van de gegevens verzamelen, zijn doorgaans zeer deskundige waarnemers. Bovendien worden de gegevens in de NDFF gevalideerd, dus ze zijn betrouwbaar. De grote kracht van de NDFF zit hem in de grote hoeveelheid gegevens. Er zitten momenteel (februari 2018) ca. 107 miljoen waarnemingen in de NDFF en alleen al voor dit onderzoek kwamen er uit de 24 geselecteerde gebieden ca. 1 miljoen waarnemingen. Maar er zitten ook nadelen aan het gebruik gegevens uit de NDFF:

- Niet elk gebied wordt even intensief bezocht door vrijwilligers. In gebieden waar meer mensen wonen, zijn doorgaans meer waarnemingen. En natuurgebieden worden beter bezocht dan agrarisch gebied, omdat de kans om 'bijzondere' soorten te zien groter is in natuurgebieden. Om hiermee rekening te houden, is in dit onderzoek alleen gewerkt met aan- of afwezigheid van soorten. Of een soort dus $1 x$ of $100 x$ is waargenomen in een gebied, maakt in de analyses geen verschil.

- Veel van de waarnemingen in de NDFF zijn zgn. losse waarnemingen, dus niet volgens een vast protocol verzameld (zoals bijvoorbeeld jaarlijks opnemen van pq's, het lopen van een vaste vlinderroute of broedvogelmonitoring). Dit hoeft voor het doel van dit onderzoek geen probleem te zijn. Voor het berekenen van de natuurpuntscore is de aanwezigheid van zgn. referentiesoorten belangrijk. Dit zijn de doelsoorten voor een natuurtype en dit zijn vaak de zeldzamere en meer bijzondere soorten. Vrijwilligers zullen juist deze soorten altijd doorgeven. Een brandnetel wordt niet altijd genoteerd, maar een orchidee wel.

- Is een gebied groter, dan is de kans op de aanwezigheid van een referentiesoort doorgaans ook groter. In deze studie lagen de oppervlakten van de wingebieden vaak tussen ca. 20-300 ha. Om na te gaan of dit van invloed was in deze studie, is het verschil in natuurpunten voor en na de winning uitgezet tegen de oppervlakte (Figuur 9 in $\S 4.1 .1$ ). Het bleek dat er weinig relatie was tussen de natuurwinst en de oppervlakte van het gebied.

- De periode waarin zand of grind gewonnen wordt in een gebied, is minimaal 5 jaar, vaak ca. 10 jaar (zie Tabel 2, in § 3.1). Veel winningen uit deze analyse zijn gestart tussen 2000 en 2010 en zijn tussen 2014 en 2016 gereed gekomen. In die periode is het aantal waarnemingen dat jaarlijks in de NDFF stroomt sterk toegenomen. Het aantal waarnemingen uit de periode 'na de winning' is bij alle gebieden groter dan het aantal waarnemingen uit de (even lange) periode voor de winning. Toch blijkt ook dit het resultaat niet al te veel te beïnvloeden (Figuur 11 in $\S 4.1 .1$ ).

Het natuurpuntensysteem is oorspronkelijk ontwikkeld voor de bouwsector, waarbij de projectperiodes vaak korter zijn dan bij zand- en grindwinning. Daarbij is vaak maar één natuurdoeltype aanwezig. De 
toets om in kortere tijdvakken de natuurpunten over de verschillende natuurdoeltypen te berekenen, levert uiteindelijk een nauwkeurigere trend op. Dit zou in een vervolgstudie nader uitgewerkt kunnen worden.

Al met al is onze conclusie dat het natuurpuntsysteem werkt voor het doel van deze studie, een vergelijking van biodiversiteit voor en na de winning. Er zit wel ruis in de gegevens, maar de kracht zit in het grote aantal waarnemingen en in het feit dat analyse over 24 verschillende gebieden is gedaan. Per gebied kunnen de uitkomsten iets verschillen, maar over de gehele linie geven de uitkomsten een eensluidend beeld.

\subsubsection{Natuurwaarde}

Het resultaat van de analyses is dat van bijna alle 24 gebieden de biodiversiteit na de winning is toegenomen ten opzichte van de situatie voor de winning. Dit geldt zowel voor het totaalaantal aanwezige soorten als voor de berekende natuurwaarde volgens het natuurpuntensysteem. Dit heeft twee belangrijke oorzaken:

1. Delfstofwinning mag geen primair op zichzelf staand doel (meer) zijn. In een integraal plan met een ander hoofddoel (zoals natuurontwikkeling, waterstandverlaging, recreatie) is delfstofwinning een middel om dit hoofddoel te bereiken. In de planfase wordt goed nagedacht over hoe het gebied er na de winning uit moet zien en hoe het beheerd gaat worden. In een vroeg stadium zijn ecologen van onderzoeksbureaus en terreinbeherende organisaties (vaak Natuurmonumenten) betrokken bij de planvorming.

2. De uitgangssituatie is meestal dat intensief gebruikte agrarische grond (intensief bemest grasland of maisakkers) wordt omgezet in natuur. De natuurwaarde op de agrarische gronden is zeer laag. In de nieuwe situatie zullen - onder invloed van de dynamiek van de rivier en een beheer gericht op spontane processen - binnen enkele jaren allerlei nieuwe soorten zich vestigen.

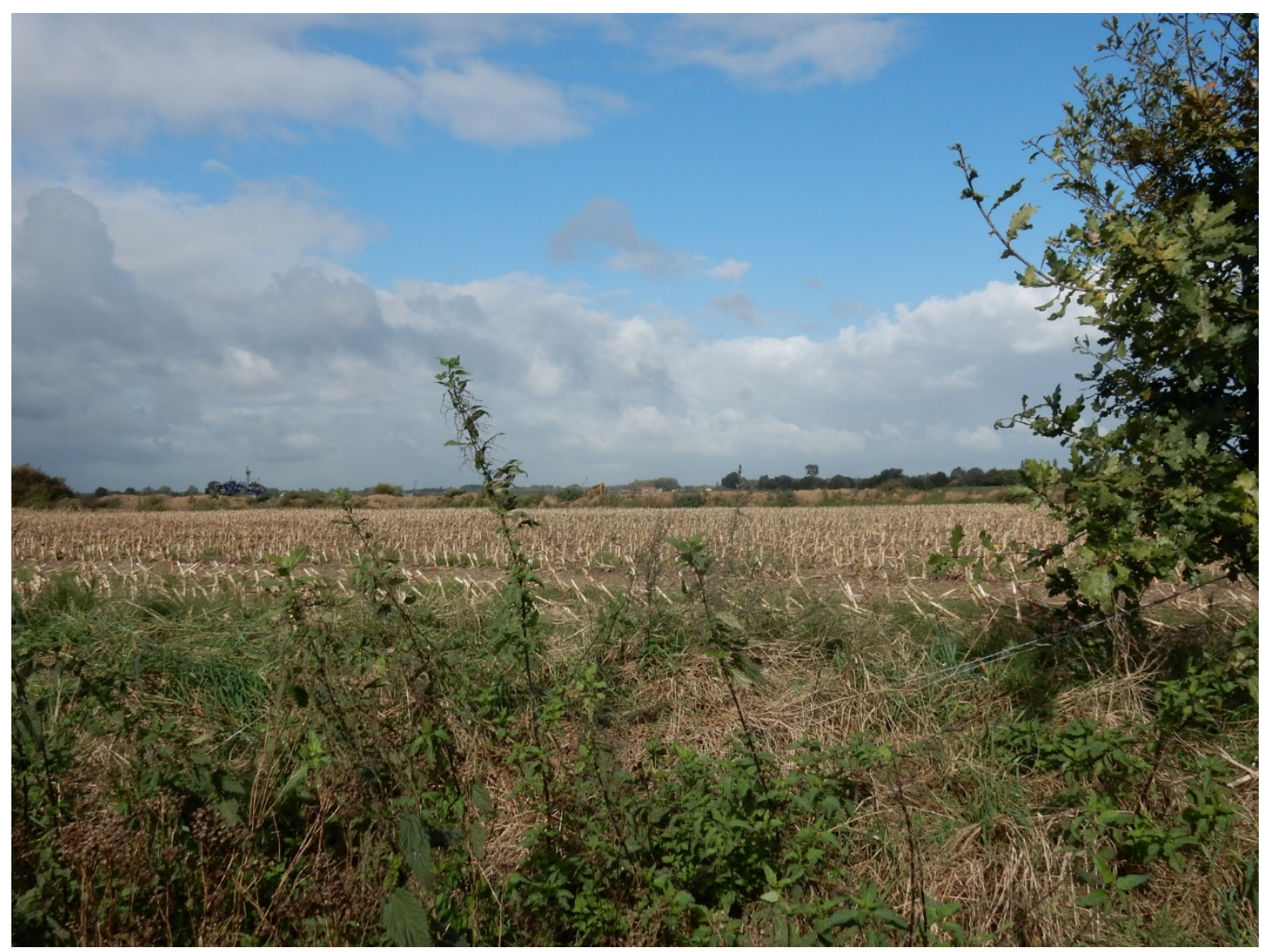

Foto 12

Project Over de Maas. Oorspronkelijke landbouwgrond (Foto: Albert Vliegenthart). 
Vergelijken we de aantallen soorten aangetroffen voor en na de winning, dan zien we bij alle soortgroepen, met uitzondering van vissen, grotere aantallen na de winning. Dagvlinders, vaatplanten en vogels vertonen de sterkste stijging in aantal. Ook het aantal soorten libellen gaat vooruit. Het aantal soorten zoogdieren voor en na de winning is min of meer gelijk, alleen het aantal soorten vissen is lager na de winning dan voor de winning. Bij de toename gaat het vooral om algemene soorten, bij de Rode Lijstsoorten en referentiesoorten is de toename veel minder groot. Dat als enige soortgroep het aantal soorten vissen afneemt, heeft waarschijnlijk te maken a) met een aantal soorten invasieve soorten uit Oost-Europa (grondels) die het gebied koloniseert en b) onvoldoende bodem op bereikbare diepte. Aan dit laatste punt kan bij het ontwerp van de watergangen en plassen mogelijk nog wat verbeterd worden.

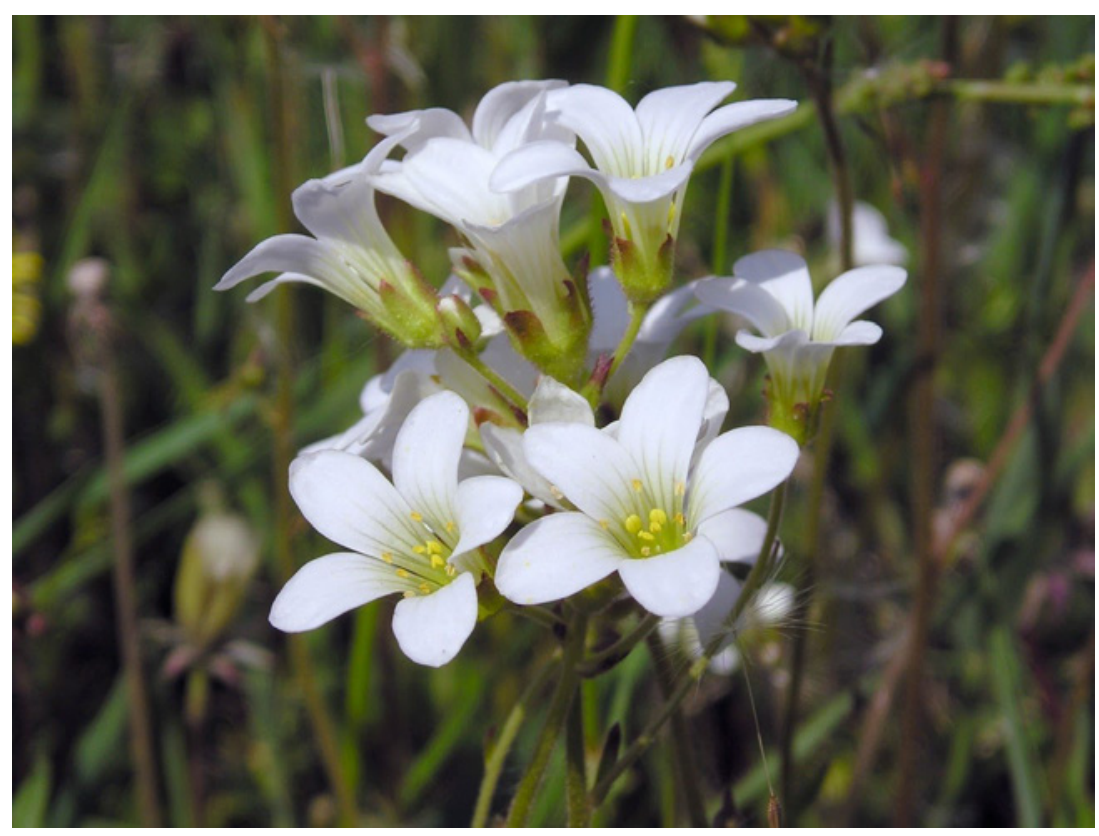

Foto 13 Knolsteenbreek, een kritische soort die hoge eisen stelt aan de groeiplaats (Foto: Friso van der Zee).

In meer detail naar de soorten kijkend, zien we dat pioniersoorten het de eerste jaren vaak prima doen. Dit zijn soorten met een goed verspreidingsvermogen die de nieuwe milieus snel weten te koloniseren. De aantallen doelsoorten van natte milieus, zoals nevengeulen en oevers, nemen sterk toe. De doelsoorten van de prioritaire Natura 2000-habitat Vochtige alluviale bossen (Ooibossen, H91E0) en met name de drogere Stroomdalgraslanden (H6120) nemen echter veel minder sterk toe. Voor natte milieus en ooibossen zullen veel soorten in de loop van de tijd waarschijnlijk wel verschijnen, hier is het advies om nog even geduld te hebben. Voor droge stroomdalgraslanden is extra inspanning nodig om deze te laten ontstaan. Allereerst moeten de juiste omstandigheden aanwezig zijn (droge rivierduintjes, kalkrijk, zandige lichte zavel), maar vervolgens zal de verspreiding voor veel van deze inmiddels zeldzame soorten een probleem zijn. De nog aanwezige restanten van populaties staan te ver weg en soorten komen er op eigen kracht niet. Indien de juiste condities wel aanwezig zijn, moet dus gedacht worden aan het inbrengen van zaad, bijv. kruidenrijk hooi van goed ontwikkeld stroomdalgrasland.

Bovenstaande resultaten komen goed overeen met de resultaten van Straatsma et al. (2017) over de effecten van het project 'Ruimte voor de Rivier' op de biodiversiteit. De algehele biodiversiteit neemt toe en vooral mobiele soorten nemen toe. Maar voor een aantal karakteristieke en indicatieve soorten van het riviergebied (zoals stroomdalgraslanden) is meer nodig.

Het veelal ontbreken van rivierduin in de projecten komt omdat stromende nevengeulen nooit zijn toegepast als maatregel om een waterstanddaling mee te bereiken. Deze nevengeulen hebben grotere morfologische effecten op het zomerbed die vervolgens de scheepvaart weer beïnvloeden. Als zelfs maar een klein deel (1\%) van het rivierwater permanent door een nevengeul stroomt, heeft dat 
meteen al aanzanding tot gevolg in het zomerbed; waardoor op plaatsen zonder overruimte de minimale gegarandeerde vaardiepte een aantal dagen per jaar niet meer wordt gehaald. (Beekers et al. 2017). Stromende nevengeulen zouden in die zin een ideaal middel zijn om rivierduinsystemen te ontwikkelen. Daarnaast heeft riviernatuur die zich ontwikkelt volgens de principes van Levende Rivieren, een hogere ruwheid dan de bestaande, overwegend agrarische vegetaties; waarmee de winst aan waterstanddaling weer deels teniet wordt gedaan. Hierdoor wordt bijvoorbeeld de vorming van (ooi)bos meestal voorkomen (Beekers et al. 2017).

Het lijkt er ook op dat geleidelijk het streefbeeld van riviernatuur is veranderd. Riviernatuur is synoniem geworden met natuur onder invloed van de dynamiek van de rivier (nevengeulen, af en toe overstromingen) en een relatief grootschalig procesbeheer d.m.v. grote grazers, goedkoop en eenvoudig te onderhouden. Struweelvorming wordt in beperkte mate geaccepteerd. Dit is terug te vinden in veel van de projectlocaties. Voor veel soorten werkt dit prima en we kunnen en mogen heel tevreden zijn met de resultaten. Als er één soort natuur de afgelopen twintig jaar vooruit is gegaan, dan is het de riviernatuur. Maar willen we ook die karakteristieke soorten in het rivierengebied vooruit helpen die wat kritischer zijn en meer eisen stellen, dan moet daar extra aandacht aan besteed worden. Dat is de uitdaging voor zowel de delfstofwinners als de andere uitvoerders van 'Ruimte voor de Rivier'-projecten.

\subsection{Waterstandverlaging}

Ondanks dat waterstandverlaging meestal geen doelstelling is, blijft de vraag van de zand- en grindwinnende industrie over de bijdrage die zij leveren aan de waterstandverlaging (en indirect de veiligheid van ons land) relevant. Om deze vraag goed te beantwoorden, zou er een duidelijke maatstaf moeten zijn om dergelijke bijdragen te kunnen berekenen. Het aantal centimeters waterstandverlaging is voor een project een duidelijk harde waarde, hoewel die verlaging over het traject logaritmisch afneemt (Figuur 4, § 2.5). Hierdoor kan het aantal gerealiseerde centimeters niet zomaar worden opgeteld en drukt men de bijdrage tegenwoordig uit in de overstromingskans. De belangrijkste bewapening tegen onze rivieren zijn de dijken.

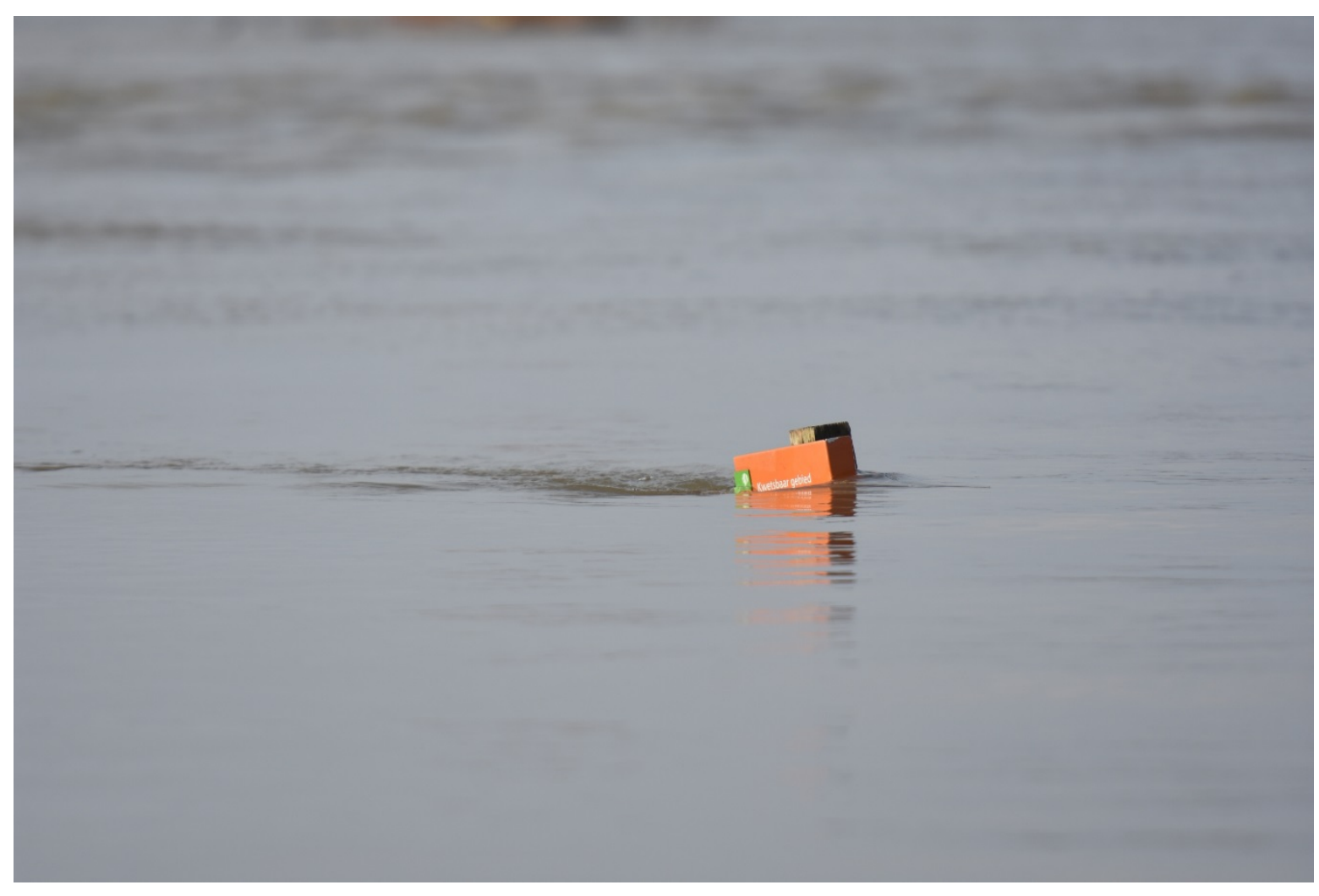


Omdat op veel plaatsen de dijkversterking niet of beperkt kan worden uitgevoerd, is het belangrijk om de dijken te ontzien van hoge waterdruk. Waterstandverlaging is dan een primaire factor. Deze kan op verschillende manieren worden bereikt. De website 'Ruimte voor de rivier' schetst verschillende maatregelen zoals kribverlaging, zomerbedverlaging, verwijderen van obstakels, nevengeulen, waterberging, ontpolderen en dijkverlegging. In veel van deze gevallen zijn zand- en grindwinnende bedrijven betrokken bij de realisatie van deze maatregelen en dragen bij aan 'Ruimte voor de Rivier'. Kater et al. (2012) tonen aan dat deze effecten positief bijdragen op de doorstroming van de rivieren. Om dan uiteindelijk de werkelijke bijdrage te berekenen zouden deze moeten worden afgewogen tegen de overheidsprojecten die worden opgelegd om meer ruimte aan de rivier te geven. Echter ook hier wordt ingezet op de verschillende maatregelen om de dijken minder te belasten en worden eveneens geen waterstandverlagingen opgegeven. Experts schatten in dat aan de hand van het aantal projecten en de omvang daarvan de zand- en grindwinnende industrie globaal voor de helft bijdraagt aan de waterstandverlaging.

De waterstandverlaging werd altijd berekend na afloop van een project als de vegetatie nog niet erg ontwikkeld is. Dat betekent dat in de praktijk als de vegetatie verder groeit en er bijvoorbeeld ooibos ontwikkelt, de vegetatie het waterstandverlagende effect gedeeltelijk tenietdoet. Daarom geeft het aantal centimeters verlaging een verkeerd beeld, omdat het uiteindelijke herstel en streefbeeld van het rivierensysteem hiermee wel is bevorderd. De effecten van nieuwe gebiedsontwikkeling dragen bij aan de doorstroming van de rivier, nieuwe natuur en uiteindelijk ook minder druk op de dijken. De bijdrage van de zand- en grindwinners zou dan ook in een breder kader moeten worden gesteld, waaruit blijkt dat de impact veel groter is dan het behaalde resultaat in centimeters waterstandverlaging.

Dat de verruiming van de rivier in de praktijk werkt, is anekdotisch in ieder geval merkbaar. De hoge waterstanden van Rijn en Waal in januari 2018 hebben nergens voor problemen gezorgd. Dit geldt ook voor de Maas. Families die soms al meerdere generaties op de oevers van de Maas wonen, merken de effecten van de rivierverruiming overduidelijk. Het waterpeil van de Maas stijgt nu veel minder na langdurige regenval. "Dat scheelt zeker een meter", zo zeggen bijvoorbeeld inwoners van Borgharen, Itteren en Meers. Hun waarnemingen worden bevestigd door de uitkomst van hydraulische onderzoeken naar het effect van de ingrepen van Consortium Grensmaas. "De waterstandverlaging is aanzienlijk. In vergelijking met 1993/1995 is de verlaging in Borgharen bijvoorbeeld 1,25 meter, in Itteren 0,95 meter en in Meers 0,80 meter. Al die dorpen in het werkgebied van het project Grensmaas houden het Maaswater nu buiten de deur." (Ron Agtersloot 2017, https://www.grensmaas.nl/effecten-ingrepen-vaak-meer-dan-meter-waterstandsverlaging.)

\subsection{Integrale samenhang}

De afgenomen interviews gaven een goed beeld van de betrokken zand- en grindwinners. Er is een groot enthousiasme en er zijn veel mooie voorbeelden waarbij nieuwe natuur is ontstaan. Het doel van dit onderzoek is te achterhalen welke factoren nu voor integraliteit zorgen en de individuele bedrijven met elkaar verbindt. Een van de redenen voor dit onderzoek is het stigma dat op deze industrie ligt. Het idee dat er bedrijven komen, gaten graven en weer verdwijnen, leeft blijkbaar nog steeds bij veel mensen. En in de praktijk komen de confrontaties met de landbouwsector ook steeds terug. Een goede aanpak en strategie is dan ook wenselijk.

De resultaten laten zien dat de aanpak van een goed omgevingsmanagement door met direct betrokkenen en belanghebbenden vroegtijdig om tafel te zitten door alle bedrijven wordt uitgevoerd. Deze aanpak is nodig en heeft al bewezen dat dit voor meer draagvlak zorgt. Omdat de projecten op verschillende locaties liggen, is er sprake van streekgericht omgevingsmanagement, dat samengevat gericht is op verkenning, planstudie en uitvoering (Rijkswaterstaat, 2010). Hierin zijn factoren als monitoring en communicatie niet meegenomen. Deze aspecten zouden wel een bijdrage kunnen leveren aan de integraliteit van de projecten. Uit een uniforme monitoring zou de opbrengst en de effecten van projecten zichtbaarder worden en met elkaar mogen worden vergeleken. Hierdoor kan de vraag over de gezamenlijke bijdrage beter worden beantwoord, maar ook door deze kennis te delen, zouden processen geoptimaliseerd kunnen worden. 
Draagvlak voor natuur is belangrijk als een bedrijf succesvol duurzaam wil ondernemen. Wanneer er weinig intrinsieke aandacht is voor natuur, zal dit nooit goed kunnen worden overgedragen. De sector laat vaak liever dat verhaal van nieuwe natuur door derden vertellen en ziet het als de taak voor consortia en de brancheorganisatie Cascade. De oplossing zit in de wisselwerking. Tijdens de interviews werden bedrijven soms enthousiast van de ontwikkelingen die de onderzoekers zagen en het benoemen van hen als terreinbeheerder of een lokale landschapsbeheerder had men nog niet zo ervaren. Er ontstond zelfs een gepaste trots. Wellicht krijgt dit idee in de toekomst navolging.

Projecten van zand- en grindwinners hebben als gemeenschappelijke drager de bijdrage aan het herstellen van de riviersystemen in Nederland. Daaraan zijn natuurontwikkeling en veiligheid inherent gekoppeld. Om een gezamenlijke strategie te ontwikkelen, zal men elkaar moeten opzoeken en kennis met elkaar moeten delen. De zand- en grindwinners zijn, zo erkennen zij zelf, te bescheiden als het gaat om het uitdragen van de successen van gerealiseerde projecten en ontwikkelingen op het gebied van natuur. Immers, het gaat om zand en grind. Maar ook op dat vlak kunnen gezamenlijke oplossingen worden gevonden in het omgaan met stikstofdepositie, handhaving op vergunningen of Natura 2000-doelstellingen. Uit ons onderzoek blijkt dat bedrijven hun eigen oplossingen toepassen en meestal ook voor zichzelf houden. Soms terecht in termen van concurrentie, maar soms zitten er ook oplossingen bij die ook voor anderen het einddoel kunnen versterken, namelijk een goed en functioneel gebied.

Er zal altijd enige discussie en weerstand blijven bij de individuele projecten. Men pakt dit over het algemeen goed aan door transparant te zijn en door met elkaar in gesprek te blijven. Over de grote lijn zijn er ruim voldoende ontwikkelingen waar de branche zich positief over uit kan laten. De zanden grindwinners zijn vaak de (financiële) motor achter gebiedsontwikkelingen. Hier word meestal landbouwgrond omgezet in natuur, waarmee stikstof wordt verwijderd en biodiversiteit toeneemt (waar de landbouw zelf overigens niet altijd blij mee is). De gebieden krijgen een maatschappelijke functie voor de omgeving. Omdat de bedrijven als een soort gebiedsmakelaar functioneren, ontstaat er ook meer maatschappelijke cohesie bij de omwonenden. En op het gebied van natuurkwaliteit kan men zeggen dat de basis is gerealiseerd en dat als de echte doelsoorten zich vestigen, deze de spreekwoordelijke kers op de taart zijn.

\subsection{Conclusies}

\section{Natuurwaarde}

1. Bij de vergelijking van de aantallen soorten aangetroffen voor en na de delfstofwinning in 24 gebieden, is vrijwel overal de biodiversiteit na afloop groter. Delfstofwinning draagt dus bij aan een verhoging van de biodiversiteit.

2. Dagvlinders, vaatplanten en vogels vertonen de sterkste stijging in aantal. Ook het aantal soorten libellen gaat vooruit. Alleen het aantal soorten vissen is gemiddeld lager na de winning dan voor de winning.

3. Bij de toename gaat het vooral om algemene soorten; bij de Rode Lijstsoorten en referentiesoorten is de toename veel minder groot. De toename betreft met name soorten van natte milieus en oevers, de doelsoorten van stroomdalgraslanden en vochtige ooibossen nemen nog niet sterk toe.

4. Het natuurpuntensysteem is bruikbaar om verschillen in biodiversiteit voor en na de winning te bepalen. Het systeem kan nog verbeterd worden, bijvoorbeeld door met kleinere tijdsintervallen te werken en daarmee een trend in de tijd zichtbaar te maken.

5. Onder invloed van de delfstofwinnende industrie zijn in het rivierengebied tal van nieuwe natuurgebieden gerealiseerd. Een selectie van 28 projecten in dit onderzoek levert 3400 ha nieuwe natuur op. Dit is al de helft van de doelstelling van 7000 ha nieuwe natuur in 2015 langs de grote rivieren, die Rijkswaterstaat in 2013 heeft afgesproken met het ministerie van LNV in het convenant 'Nadere uitwerking voor rivierengebied'.

6. De natuurgebieden liggen als een kralenketting langs de rivier, waarbij de rivier zelf de robuuste verbinding vormt, zeker als het gaat om de natte natuur. 


\section{Waterstandverlaging}

1. De delfstofwinnende industrie levert met zand- en grindwinprojecten een aanzienlijke bijdrage aan de waterveiligheid. In totaal leveren de 28 projecten uit dit onderzoek ruim 370 centimeter waterstandverlaging in de rivier op.

2. Hoe de bijdrage van de delfstofwinners aan waterveiligheid zich verhoudt tot andere 'Ruimte voor de Rivier'-projecten, valt moeilijk met harde cijfers uit te drukken. Experts schatten in dat die verhouding ca. $50-50$ is.

\section{Integrale samenhang}

1. De sector fungeert duidelijk als motor voor gebiedsontwikkeling. Veel van de huidige nieuwe natuur bij terreinbeherende organisaties in het rivierengebied zou zonder de sector niet gerealiseerd zijn. De realisatie van nieuwe natuur en waterveiligheid door de delfstofwinnende industrie is voor Nederland aantrekkelijk. Natuurontwikkeling en waterveiligheid worden op kosten van het bedrijfsleven gerealiseerd en daarmee in feite gratis voor de BV Nederland.

2. De mate waarin bedrijven zich met natuur en biodiversiteit bezighouden, verschilt per bedrijf. Sommige bedrijven profileren zich sterk op dit vlak met veel pr. Anderen zien zich meer sec als uitvoerder en laten deze aspecten over aan het consortium of, als het om belangenbehartiging en imago gaat, aan Cascade. Over het geheel genomen is de sector erg bescheiden over de gerealiseerde natuur, veel van de erkenning belandt bij partijen als Natuurmonumenten of andere organisaties die het gebied na afloop van de winning beheren. Over het geheel genomen is de sector bescheiden over de gerealiseerde natuur; veel van de erkenning belandt bij Natuurmonumenten (of andere organisaties) die het gebied na afloop van de winning gaat beheren.

3. Regelgeving als het Programma Aanpak Stikstof (PAS) wordt soms als knellend ervaren. Dit komt mede door de lange termijnen van projecten (20-30 jaar). Zaken als tijdelijkheid van winningsprojecten in een gebied en het uiteindelijk netto positieve effect op stikstofdepositie worden daardoor gemist en niet gesaldeerd binnen het PAS.

4. De vergunningsverlening is heel gedetailleerd, waarbij de handhaving bij oplevering strikt kijkt naar wat ooit is afgesproken (bijv. afmetingen profiel), terwijl bij dynamische riviernatuur meer flexibiliteit past.

5. De bever is mooie soort als vaandeldrager voor de delfstofwinners.

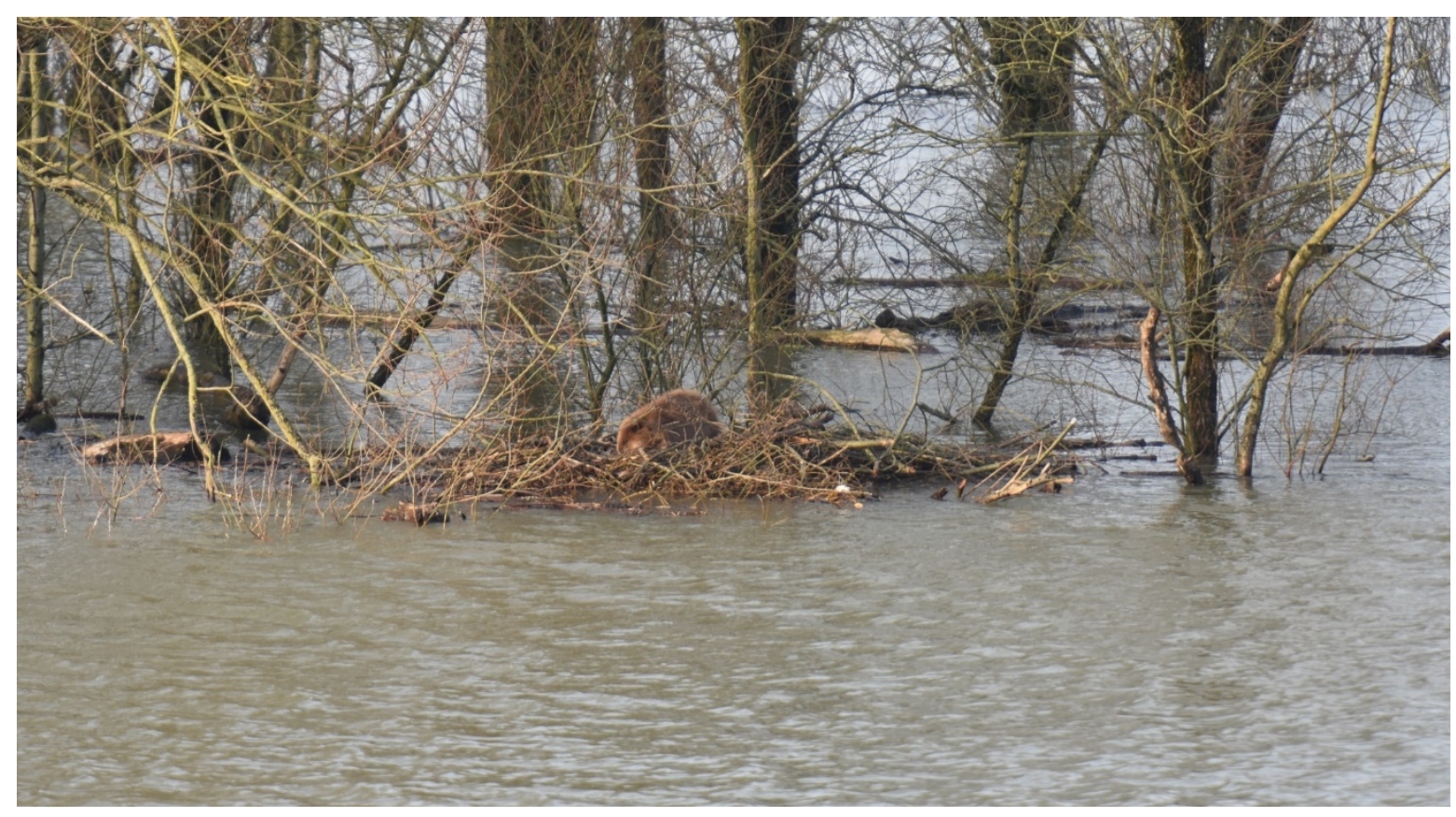




\subsection{Aanbevelingen}

Op basis van het onderzoek komen wij tot de volgende aanbevelingen:

- De bijdrage van de sector aan natuur en waterveiligheid is hoog. Qua prioritaire Natura 2000 habitattypen kan extra aandacht gegeven worden aan 'stroomdalgrasland' en 'vochtige ooibossen'. Dit vereist extra aandacht in de planfase, maar ook in uitvoering (geschikt maken milieu, evt. inbrengen gewenste soorten) en het beheer na afloop.

- Een uitontwikkeld natuurpuntensysteem met draagvlak bij overheden (de provincie is voor deze branche het bevoegd gezag) zou helpen bij het eenvoudig objectief vaststellen van natuurwaarden en daarmee het bepalen van toegevoegde waarde van projecten. Deze waarde kan dan ook in de footprint van de geproduceerde grondstoffen worden meegewogen.

- Er kan veel meer pr voor de goede resultaten op het gebied van biodiversiteit en waterveiligheid gemaakt worden, de sector is op dit vlak zeer bescheiden. Die bescheidenheid is onnodig en de sector mag haar successen best meer uitdragen in bijeenkomsten. Een voorbeeldenboek van goed geslaagde projecten, liefst gemaakt door een onafhankelijke derde partij, kan daarbij ook helpen.

- Gebieden na afloop van de winning in eigen beheer houden vergroot de mogelijkheid om de credits voor natuur vanzelfsprekender bij de sector terecht te laten komen En er ontstaat ook meer inhoudelijke kennis over natuurbeheer. 


\section{Literatuur}

Bak, R.L. (2012). Uit eigen bodem - facetten van ontgrondingen.

Bal D, Beije H, Fellinger M, Haveman R, Van Opstal A, Van Zadelhoff F. 2001. Handboek natuurdoeltypen; 2e geheel herz.

Beekers, B., van den Bergh, M., Braakhekke, W., Haanraads, K., Litjens, G., van Loenen Martinet, R., van de Mark, C., Otterman, E., Pluimers, J., Rademakers, J., Reeze, B., Sterk, M., Teunissen, T., Willems, D. \& van Winden, A., 2017. Ruimte voor Levende Rivieren - achtergronddocument. Bureau Stroming i.s.m. Stichting ARK, Natuurmonumenten, Vogelbescherming, Wereldnatuurfonds, LandschappenNL en de Milieufederaties.

Boerboom, R., Berendsen, Heijne, J., G. ter \& A. Kaminski (2010); Inventarisatie Azewijnse Broek 2009: resultaten van de veldinventarisatie naar flora en fauna in 2009. Rapport 1010, Staring Advies, Zelhem.

Boonman, P. 2013. MER Randwijkse Uiterwaarden. Grontmij Nederland B.V., in opdracht van Dekker Grondstoffen B.V.. Referentie GM-0070850.

Bos, F., Bosveld, M., Groenendijk, D., Swaay, C. van, Wynhoff, I., De Vlinderstichting (2006): De dagvlinders van Nederland : verspreiding en bescherming : (Lepidoptera: Hesperioidea, Papilionoidea). (Nederlandse Fauna 7) - Nationaal Natuurhistorisch Museum Naturalis, Leiden; KNNV Uitgeverij, Utrecht \& European Invertebrate Survey-Nederland, Leiden.

Bouwman, J.H., Kalkman, V.J., Abbingh, G., de Boer, E.P., Geraeds, R.P.G., Groenendijk, D., Ketelaar, R., Manger, R. \& T. Termaat (2008); Een actualisatie van de verspreiding van de Nederlandse libellen. Brachytron 11 (2): 103-198.

Calle, P., De Knijf, G., Kurstjens, G. \& B. Peters (2007); Actuele en historische libellenfauna van de Grensmaas. Natuurhistorisch Maandblad 96 (10): 269-277.

Duinen, G.A. van, Kleef, H.H. van, Nijssen, M., Turnhout, C.A.M. van, Verberk, W.C.E.P., Holtland, J. \& H. Esselink (2004); Schaal en intensiteit van herstelmaatregelen: hoe reageert de fauna? Rapport EC-LNV nr. 2004/305 p.189-239.

Goutbeek, A.B. \& M. Zekhuis (2005); Grond voor natuur, verkenning van de actuele en potentiële natuurwaarden van zandwinplassen in Overijssel. Landschap Overijssel, Huis de Horte, Dalfsen.

Hartgers, E., M. van Buuren, R.J. Fontein, T. van Hattum, H.J. de Lange en G. Maas, 2015. Natuurrealisatie in het programma Ruimte voor de Rivier; Wat zijn de leerpunten van het programma Ruimte voor de Rivier voor combineren van water- en natuuropgaven? Wageningen, Alterra Wageningen UR (University \& Research centre), Alterra-rapport 2687. 76 blz.; 8 fig.; 1 tab.; 30 ref.

Hijlkema, J., Lok, J. Reerink, I. \& Smits, M. 2017. De meerwaarde van kleiwinning, Onderzoek naar kleiwinningen langs de Grote Rivieren sinds 2000. Vereniging Koninklijke Nederlandse Bouwkeramiek (KNB), Velp (Gld) K3Delta, Nijmegen.

Jaspers CJ, Mouissie M, Wessels S, Barke J, Kolen M, Bucholc A. 2016. Natuurpuntensysteem voor uniforme waardering van natuurkwaliteit. No. 346417. 
Jaspers H. 2017. Referentielijsten natuurpuntensysteem. In: Geselecteerde natuurdoeltypen Natuurpunten soortengroepen soortenlijsten en weegfactoren, editor. De Bilt: Sweco.

Kater, E., Makaske, B. \& Maas, G. 2012. Morfodynamiek langs de grote rivieren Inventarisatie van processen en evaluatie van maatregelen. Directie Kennis en Innovatie, Ministerie van Economische Zaken, Landbouw en Innovatie Rapport nr. 2012/OBN154-RI Den Haag, 2012.

Kurstjens G., Peters, B \& P. Calle (2008); Maas in beeld: Resultaten van 15 jaar ecologisch herstel. Gebiedsrapport 1: Bovenmaas en Grensmaas. Kurstjens ecologisch adviesbureau \& Bureau Drift. pp. 142.

Lange, H.J. de, Gylstra, R., Huijsmans, T., Sluiter, H., Timmermans, F., Besse-Lototskaya, A.A., Brink, N.W. van den. 2015. Optimaliseren herinrichting van diepe plassen : Technisch achtergronddocument bij de MCA Verondiepen, een multicriteria-instrument om locatiekeuze en inrichtingsvariant te optimaliseren. Alterra, Wageningen-UR (Stowa rapport 2015-40) - 48 p.

Van der Linden, M.G.A.M. (2007): Alternatieven voor de ecologische functies van de zandwinput in het Gooimeer bij Naarden. Nadere uitwerking. Slibbank Nederland, RPS BCC, Leerdam.

Van Looy, K., Kurstjens, G. \& B. Peters (2009); Maas in Beeld - Resultaten van 15 jaar ecologisch herstel - Vlaamse Maasvallei. Depotnummer: D/2009/8362/11: 150p.

Nederlandse Vereniging voor Libellenstudie (2002): De Nederlandse libellen (Odonata) (Nederlandse Fauna ; 4) - Nationaal Natuurhistorisch Museum Naturalis, KNNV Uitgeverij \& EIS-Nederland, Leiden.

Ostë, A., Jaarsma, N. \& Oosterhout, F. van, 2010. Een heldere kijk op diepe plassen. Kennisdocument diepe meren en plassen: ecologische systeemanalyse, diagnose en maatregelen.

PBL, (2014). Natuurpunten: kwantificering van effecten op natuurlijke ecosystemen en biodiversiteit in het Deltaprogramma - achtergrondstudie. Publicatienummer 1263, PBL (Planbureau voor de Leefomgeving), Den Haag.

Peters, B.\&G. Kurstjens (2007); Rivierenland in ontwikkeling - deel 2 resultaten van natuurontwikkeling in het riviergebied. Bureau Drift /Kurstjens ecologisch adviesbureau, Berg en Dal / Beek Ubbergen. Pp. 162.

Peters, B. \& G. Kurstjens (2008); Maas in beeld: succesfactoren voor een natuurlijke rivier. Projectgroep Maas in Beeld. Bureau Drift /Kurstjens ecologisch adviesbureau, Berg en Dal / Beek Ubbergen. Pp. 99.

Rijkswaterstaat. 2010. Omgevingsmanagement: zo werkt het in de natte infrastructuur - van planstudie naar realisatie en beheer \& onderhoud. Rijkswaterstaat.

Romijn, G. en G. Renes, 2013. Algemene leidraad voor maatschappelijke kosten-batenanalyse. CPB/PBL, Den Haag.

Sýkora, K. \& S. Rotthier, 2014. Stroomdalgrasland: kort en laagdynamisch. De Levende Natuur 115 (3): 134-139. 


\section{Bijlage 1 Soortenlijst}

De soorten zijn gesorteerd per soortgroep; daarbinnen op de rechter $\left(=5^{\mathrm{e}}\right)$ kolom zijnde het verschil tussen 'aantal keer vooraf wel waargenomen en achteraf niet' en 'aantal keer achteraf wel waargenomen en vooraf niet' ( $=$ kolom 2 min kolom 3 ). Per soortgroep staan de soorten die zijn 'achteruitgegaan' dus bovenaan en de soorten die 'vooruit zijn gegaan' onderaan.
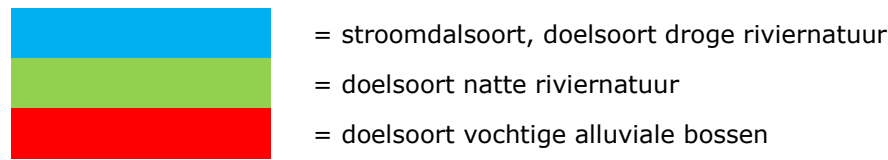

\begin{tabular}{|c|c|c|c|c|c|c|c|}
\hline srtgroepen & soort_ned & soort_wet & not & \multicolumn{3}{|c|}{ vr na vr+na } & vr-na \\
\hline Dagvlinders & staartblauwtje & Cupido argiades & 23 & 1 & 0 & 0 & 1 \\
\hline Dagvlinders & grote vos & Nymphalis polychloros & 23 & 1 & 0 & 0 & 1 \\
\hline Dagvlinders & resedawitje & Pontia daplidice & 23 & 1 & 0 & 0 & 1 \\
\hline Dagvlinders & koninginnenpage & Papilio machaon & 5 & 3 & 3 & 13 & 0 \\
\hline Dagvlinders & dwergblauwtje & Cupido minimus & 23 & 0 & 1 & 0 & -1 \\
\hline Dagvlinders & eikenpage & Favonius quercus & 23 & 0 & 1 & 0 & -1 \\
\hline Dagvlinders & kleine ijsvogelvlinder & Limenitis camilla & 23 & 0 & 1 & 0 & -1 \\
\hline Dagvlinders & dambordje & Melanargia galathea & 23 & 0 & 1 & 0 & -1 \\
\hline Dagvlinders & geelsprietdikkopje & Thymelicus sylvestris & 23 & 0 & 1 & 0 & -1 \\
\hline Dagvlinders & kaasjeskruiddikkopje & Carcharodus alceae & 21 & 0 & 1 & 2 & -1 \\
\hline Dagvlinders & boswitje & Leptidea sinapis & 20 & 0 & 1 & 3 & -1 \\
\hline Dagvlinders & grote weerschijnvlinder & Apatura iris & 22 & 0 & 2 & 0 & -2 \\
\hline Dagvlinders & argusvlinder & Lasiommata megera & 16 & 2 & 4 & 2 & -2 \\
\hline Dagvlinders & kleine parelmoervlinder & Issoria lathonia & 16 & 2 & 5 & 1 & -3 \\
\hline Dagvlinders & gele luzernevlinder & Colias hyale & 15 & 1 & 5 & 3 & -4 \\
\hline Dagvlinders & dagpauwoog & Aglais io & 0 & 1 & 5 & 18 & -4 \\
\hline Dagvlinders & koevinkje & Aphantopus hyperantus & 18 & 0 & 5 & 1 & -5 \\
\hline Dagvlinders & kleine vos & Aglais urticae & 1 & 1 & 6 & 16 & -5 \\
\hline Dagvlinders & klein koolwitje & Pieris rapae & 1 & 1 & 6 & 16 & -5 \\
\hline Dagvlinders & atalanta & Vanessa atalanta & 0 & 1 & 6 & 17 & -5 \\
\hline Dagvlinders & bruin blauwtje & Aricia agestis & 10 & 2 & 7 & 5 & -5 \\
\hline Dagvlinders & groot dikkopje & Ochlodes sylvanus & 8 & 3 & 8 & 5 & -5 \\
\hline Dagvlinders & gehakkelde aurelia & Polygonia c-album & 2 & 2 & 8 & 12 & -6 \\
\hline Dagvlinders & zwartsprietdikkopje & Thymelicus lineola & 8 & 3 & 9 & 4 & -6 \\
\hline Dagvlinders & distelvlinder & Vanessa cardui & 1 & 0 & 7 & 16 & -7 \\
\hline Dagvlinders & oranje zandoogje & Pyronia tithonus & 14 & 1 & 8 & 1 & -7 \\
\hline Dagvlinders & icarusblauwtje & Polyommatus icarus & 1 & 1 & 8 & 14 & -7 \\
\hline Dagvlinders & klein geaderd witje & Pieris napi & 0 & 1 & 8 & 15 & -7 \\
\hline Dagvlinders & oranjetipje & Anthocharis cardamines & 4 & 1 & 9 & 10 & -8 \\
\hline Dagvlinders & oranje luzernevlinder & Colias croceus & 3 & & 10 & 9 & -8 \\
\hline Dagvlinders & bont zandoogje & Pararge aegeria & 0 & & 10 & 12 & -8 \\
\hline Dagvlinders & groot koolwitje & Pieris brassicae & 2 & & 10 & 11 & -9 \\
\hline Dagvlinders & hooibeestje & Coenonympha pamphilus & 12 & & 10 & 2 & -10 \\
\hline Dagvlinders & bruin zandoogje & Maniola jurtina & 2 & & 10 & 12 & -10 \\
\hline Dagvlinders & boomblauwtje & Celastrina argiolus & 7 & & 12 & 4 & -11 \\
\hline Dagvlinders & citroenvlinder & Gonepteryx rhamni & 2 & & 13 & 9 & -13 \\
\hline Dagvlinders & kleine vuurvlinder & Lycaena phlaeas & 2 & & 15 & 6 & -14 \\
\hline Dagvlinders & landkaartje & Araschnia levana & 3 & & 17 & 4 & -17 \\
\hline Libellen & Viervlek & Libellula quadrimaculata & 17 & 4 & 1 & 2 & 3 \\
\hline Libellen & Blauwe glazenmaker & Aeshna cyanea & 12 & 5 & 2 & 5 & 3 \\
\hline Libellen & Zwervende pantserjuffer & Lestes barbarus & 22 & 2 & 0 & 0 & 2 \\
\hline Libellen & Metaalglanslibel & Somatochlora metallica & 22 & 2 & 0 & 0 & 2 \\
\hline Libellen & Geelvlekheidelibel & Sympetrum flaveolum & 20 & 3 & 1 & 0 & 2 \\
\hline Libellen & Gewone pantserjuffer & Lestes sponsa & 19 & 3 & 1 & 1 & 2 \\
\hline
\end{tabular}




\begin{tabular}{|c|c|c|c|c|c|c|c|}
\hline srtgroepen & soort_ned & soort_wet & not & \multicolumn{3}{|c|}{ vr na vr+na } & a vr-na \\
\hline Libellen & Tengere pantserjuffer & Lestes virens & 19 & 3 & 1 & 1 & 2 \\
\hline Libellen & Bosbeekjuffer & Calopteryx virgo & 23 & 1 & 0 & 0 & 1 \\
\hline Libellen & Tangpantserjuffer & Lestes dryas & 23 & 1 & 0 & 0 & 1 \\
\hline Libellen & Zuidelijke heidelibel & Sympetrum meridionale & 23 & 1 & 0 & 0 & 1 \\
\hline Libellen & Zuidelijke glazenmaker & Aeshna affinis & 23 & 0 & 0 & 1 & 0 \\
\hline Libellen & Bruine korenbout & Libellula fulva & 22 & 1 & 1 & 0 & 0 \\
\hline Libellen & Bandheidelibel & Sympetrum pedemontanum & 22 & 1 & 1 & 0 & 0 \\
\hline Libellen & Zwarte heidelibel & Sympetrum danae & 21 & 1 & 1 & 1 & 0 \\
\hline Libellen & Beekrombout & Gomphus vulgatissimus & 20 & 2 & 2 & 0 & 0 \\
\hline Libellen & Kanaaljuffer & Erythromma lindenii & 13 & 4 & 4 & 3 & 0 \\
\hline Libellen & Lantaarntje & Ischnura elegans & 1 & 4 & 4 & 15 & 0 \\
\hline Libellen & Houtpantserjuffer & Chalcolestes viridis & 10 & 5 & 5 & 4 & 0 \\
\hline Libellen & Gewone bronlibel & Cordulegaster boltonii & 23 & 0 & 1 & 0 & -1 \\
\hline Libellen & Zuidelijke oeverlibel & Orthetrum brunneum & 23 & 0 & 1 & 0 & -1 \\
\hline Libellen & Beekoeverlibel & Orthetrum coerulescens & 23 & 0 & 1 & 0 & -1 \\
\hline Libellen & Smaragdlibel & Cordulia aenea & 17 & 2 & 3 & 2 & -1 \\
\hline Libellen & Koraaljuffer & Ceriagrion tenellum & 22 & 0 & 2 & 0 & -2 \\
\hline Libellen & Plasrombout & Gomphus pulchellus & 18 & 1 & 3 & 2 & -2 \\
\hline Libellen & Vroege glazenmaker & Aeshna isoceles & 17 & 1 & 3 & 3 & -2 \\
\hline Libellen & Glassnijder & Brachytron pratense & 17 & 2 & 4 & 1 & -2 \\
\hline Libellen & Vuurjuffer & Pyrrhosoma nymphula & 14 & 2 & 4 & 4 & -2 \\
\hline Libellen & Azuurwaterjuffer & Coenagrion puella & 8 & 2 & 4 & 10 & -2 \\
\hline Libellen & Variabele waterjuffer & Coenagrion pulchellum & 14 & 3 & 5 & 2 & -2 \\
\hline Libellen & Zuidelijke keizerlibel & Anax parthenope & 20 & 0 & 3 & 1 & -3 \\
\hline Libellen & Rivierrombout & Gomphus flavipes & 19 & 0 & 3 & 2 & -3 \\
\hline Libellen & Vuurlibel & Crocothemis erythraea & 12 & 2 & 5 & 5 & -3 \\
\hline Libellen & Grote roodoogjuffer & Erythromma najas & 12 & 2 & 5 & 5 & -3 \\
\hline Libellen & Blauwe breedscheenjuffer & Platycnemis pennipes & 9 & 3 & 6 & 6 & -3 \\
\hline Libellen & Platbuik & Libellula depressa & 4 & 4 & 7 & 9 & -3 \\
\hline Libellen & Bruine glazenmaker & Aeshna grandis & 14 & 1 & 5 & 4 & -4 \\
\hline Libellen & Kleine roodoogjuffer & Erythromma viridulum & 10 & 2 & 6 & 6 & -4 \\
\hline Libellen & Tengere grasjuffer & Ischnura pumilio & 14 & 3 & 7 & 0 & -4 \\
\hline Libellen & Steenrode heidelibel & Sympetrum vulgatum & 10 & 3 & 7 & 4 & -4 \\
\hline Libellen & Bruinrode heidelibel & Sympetrum striolatum & 7 & 4 & 8 & 5 & -4 \\
\hline Libellen & Bloedrode heidelibel & Sympetrum sanguineum & 5 & 4 & 8 & 7 & -4 \\
\hline Libellen & Zwervende heidelibel & Sympetrum fonscolombii & 15 & 0 & 5 & 4 & -5 \\
\hline Libellen & Paardenbijter & Aeshna mixta & 6 & 1 & 6 & 11 & -5 \\
\hline Libellen & Gewone oeverlibel & Orthetrum cancellatum & 1 & 2 & 7 & 14 & -5 \\
\hline Libellen & Watersnuffel & Enallagma cyathigerum & 7 & 1 & 8 & 8 & -7 \\
\hline Libellen & Weidebeekjuffer & Calopteryx splendens & 1 & 2 & 9 & 12 & -7 \\
\hline Libellen & Bruine winterjuffer & Sympecma fusca & 13 & 0 & 8 & 3 & -8 \\
\hline Libellen & Grote keizerlibel & Anax imperator & 3 & 1 & 9 & 11 & -8 \\
\hline Vaatplanten & Taraxacum & Taraxacum & 16 & 7 & 0 & 1 & 7 \\
\hline Vaatplanten & Bermzuring & Rumex $x$ pratensis & 17 & 5 & 1 & 1 & 4 \\
\hline Vaatplanten & Canadapopulier & Populus $\mathrm{x}$ canadensis & 13 & 5 & 1 & 5 & 4 \\
\hline Vaatplanten & Ruige weegbree & Plantago media & 11 & 6 & 2 & 5 & 4 \\
\hline Vaatplanten & Kool / Wilde kool & Brassica oleracea & 21 & 3 & 0 & 0 & 3 \\
\hline Vaatplanten & Elzenzegge & Carex elongata & 21 & 3 & 0 & 0 & 3 \\
\hline Vaatplanten & Blaaszegge & Carex vesicaria & 21 & 3 & 0 & 0 & 3 \\
\hline Vaatplanten & Vlottende waterranonkel & Ranunculus fluitans & 21 & 3 & 0 & 0 & 3 \\
\hline Vaatplanten & Hennep & Cannabis sativa & 20 & 3 & 0 & 1 & 3 \\
\hline Vaatplanten & Sporkehout & Rhamnus frangula & 20 & 3 & 0 & 1 & 3 \\
\hline Vaatplanten & Wilde lijsterbes & Sorbus aucuparia & 14 & 6 & 3 & 1 & 3 \\
\hline Vaatplanten & Sofiekruid & Descurainia sophia & 22 & 2 & 0 & 0 & 2 \\
\hline Vaatplanten & Melkeppe & Peucedanum palustre & 22 & 2 & 0 & 0 & 2 \\
\hline Vaatplanten & Hemelsleutel & Sedum telephium & 22 & 2 & 0 & 0 & 2 \\
\hline Vaatplanten & Driebloemige nachtschade & Solanum triflorum & 22 & 2 & 0 & 0 & 2 \\
\hline Vaatplanten & Zeegroene muur & Stellaria palustris & 22 & 2 & 0 & 0 & 2 \\
\hline Vaatplanten & Wijnstok & Vitis vinifera & 22 & 2 & 0 & 0 & 2 \\
\hline Vaatplanten & Moeslook & Allium oleraceum & 21 & 2 & 0 & 1 & 2 \\
\hline Vaatplanten & Schaduwgras & Poa nemoralis & 20 & 2 & 0 & 2 & 2 \\
\hline Vaatplanten & Nerfamarant & Amaranthus blitoides & 19 & 2 & 0 & 3 & 2 \\
\hline Vaatplanten & Knolsteenbreek & Saxifraga granulata & 19 & 2 & 0 & 3 & 2 \\
\hline Vaatplanten & Gingellikruid & Guizotia abyssinica & 20 & 3 & 1 & 0 & 2 \\
\hline
\end{tabular}




\begin{tabular}{|c|c|c|c|c|c|c|c|}
\hline srtgroepen & soort_ned & soort_wet & not & \multicolumn{3}{|c|}{ vr na vr+na } & a vr-na \\
\hline Vaatplanten & Haarfonteinkruid & Potamogeton trichoides & 20 & 3 & 1 & 0 & 2 \\
\hline Vaatplanten & Hongaarse raket & Sisymbrium altissimum & 20 & 3 & 1 & 0 & 2 \\
\hline Vaatplanten & Gewone vogelkers & Prunus padus & 16 & 3 & 1 & 4 & 2 \\
\hline Vaatplanten & Grote bevernel & Pimpinella major & 11 & 6 & 4 & 3 & 2 \\
\hline Vaatplanten & Smalle weegbree & Plantago lanceolata & 0 & 6 & 4 & 14 & 2 \\
\hline Vaatplanten & Geel duizendblad & Achillea filipendulina & 23 & 1 & 0 & 0 & 1 \\
\hline Vaatplanten & Helmgras & Ammophila arenaria & 23 & 1 & 0 & 0 & 1 \\
\hline Vaatplanten & Valse kamille & Anthemis arvensis & 23 & 1 & 0 & 0 & 1 \\
\hline Vaatplanten & Tuinmelde & Atriplex hortensis & 23 & 1 & 0 & 0 & 1 \\
\hline Vaatplanten & Velddravik & Bromus racemosus subsp. racemosus & 23 & 1 & 0 & 0 & 1 \\
\hline Vaatplanten & Hennegras & Calamagrostis canescens & 23 & 1 & 0 & 0 & 1 \\
\hline Vaatplanten & Kruldistel $x$ Knikkende distel & Carduus $\mathrm{x}$ stangii & 23 & 1 & 0 & 0 & 1 \\
\hline Vaatplanten & Vlakke dwergmispel & Cotoneaster horizontalis & 23 & 1 & 0 & 0 & 1 \\
\hline Vaatplanten & Duizendschoon & Dianthus barbatus & 23 & 1 & 0 & 0 & 1 \\
\hline Vaatplanten & Slipbladkaardebol & Dipsacus laciniatus & 23 & 1 & 0 & 0 & 1 \\
\hline Vaatplanten & Scherpe fijnstraal & Erigeron acris & 23 & 1 & 0 & 0 & 1 \\
\hline Vaatplanten & Moeraswolfsmelk & Euphorbia palustris & 23 & 1 & 0 & 0 & 1 \\
\hline Vaatplanten & Festuca & Festuca ovina/cinerea/filiformis & 23 & 1 & 0 & 0 & 1 \\
\hline Vaatplanten & Brede raai & Galeopsis ladanum & 23 & 1 & 0 & 0 & 1 \\
\hline Vaatplanten & Bleekgele hennepnetel & Galeopsis segetum & 23 & 1 & 0 & 0 & 1 \\
\hline Vaatplanten & Stengelomvattend havikskruid & Hieracium amplexicaule & 23 & 1 & 0 & 0 & 1 \\
\hline Vaatplanten & Mansbloed & Hypericum androsaemum & 23 & 1 & 0 & 0 & 1 \\
\hline Vaatplanten & Liggend hertshooi & Hypericum humifusum & 23 & 1 & 0 & 0 & 1 \\
\hline Vaatplanten & Borstelbies & Isolepis setacea & 23 & 1 & 0 & 0 & 1 \\
\hline Vaatplanten & Rechte rus & Juncus alpinoarticulatus & 23 & 1 & 0 & 0 & 1 \\
\hline Vaatplanten & Zilte rus & Juncus gerardii & 23 & 1 & 0 & 0 & 1 \\
\hline Vaatplanten & Gele zeepboom & Koelreuteria paniculata & 23 & 1 & 0 & 0 & 1 \\
\hline Vaatplanten & Kompassla fo. integrifolia & Lactuca serriola fo. integrifolia & 23 & 1 & 0 & 0 & 1 \\
\hline Vaatplanten & Ingesneden dovenetel & Lamium hybridum & 23 & 1 & 0 & 0 & 1 \\
\hline Vaatplanten & Hartgespan & Leonurus cardiaca & 23 & 1 & 0 & 0 & 1 \\
\hline Vaatplanten & Dessertbladen & Malva verticillata & 23 & 1 & 0 & 0 & 1 \\
\hline Vaatplanten & Pepermunt & Mentha $\mathrm{x}$ piperita & 23 & 1 & 0 & 0 & 1 \\
\hline Vaatplanten & Veelkleurig vergeet-mij-nietje & Myosotis discolor & 23 & 1 & 0 & 0 & 1 \\
\hline Vaatplanten & Kransvederkruid & Myriophyllum verticillatum & 23 & 1 & 0 & 0 & 1 \\
\hline Vaatplanten & Valse wingerd & Parthenocissus inserta & 23 & 1 & 0 & 0 & 1 \\
\hline Vaatplanten & Zwarte den & Pinus nigra & 23 & 1 & 0 & 0 & 1 \\
\hline Vaatplanten & Oosterse plataan & Platanus orientalis & 23 & 1 & 0 & 0 & 1 \\
\hline Vaatplanten & Brede eikvaren & Polypodium interjectum & 23 & 1 & 0 & 0 & 1 \\
\hline Vaatplanten & Aardbeiganzerik & Potentilla sterilis & 23 & 1 & 0 & 0 & 1 \\
\hline Vaatplanten & Pruim & Prunus domestica subsp. domestica & 23 & 1 & 0 & 0 & 1 \\
\hline Vaatplanten & Wilde peer & Pyrus pyraster & 23 & 1 & 0 & 0 & 1 \\
\hline Vaatplanten & Grote waterranonkel & Ranunculus peltatus & 23 & 1 & 0 & 0 & 1 \\
\hline Vaatplanten & Bolletjesraket & Rapistrum rugosum & 23 & 1 & 0 & 0 & 1 \\
\hline Vaatplanten & Azijnboom & Rhus typhina & 23 & 1 & 0 & 0 & 1 \\
\hline Vaatplanten & Alpenbes & Ribes alpinum & 23 & 1 & 0 & 0 & 1 \\
\hline Vaatplanten & Valse akkerkers & Rorippa $\mathrm{x}$ armoracioides & 23 & 1 & 0 & 0 & 1 \\
\hline Vaatplanten & Slipbladige rudbeckia & Rudbeckia laciniata & 23 & 1 & 0 & 0 & 1 \\
\hline Vaatplanten & Kraak- x Schietwilg & Salix $x$ rubens & 23 & 1 & 0 & 0 & 1 \\
\hline Vaatplanten & Rogge & Secale cereale & 23 & 1 & 0 & 0 & 1 \\
\hline Vaatplanten & Driebladvetkruid & Sedum sarmentosum & 23 & 1 & 0 & 0 & 1 \\
\hline Vaatplanten & Schaduwkruiskruid & Senecio nemorensis & 23 & 1 & 0 & 0 & 1 \\
\hline Vaatplanten & Besanjelier & Silene baccifera & 23 & 1 & 0 & 0 & 1 \\
\hline Vaatplanten & Spiesraket & Sisymbrium loeselii & 23 & 1 & 0 & 0 & 1 \\
\hline Vaatplanten & Donsnachtschade & Solanum villosum & 23 & 1 & 0 & 0 & 1 \\
\hline Vaatplanten & Blonde egelskop & Sparganium erectum subsp. neglectum & 23 & 1 & 0 & 0 & 1 \\
\hline Vaatplanten & Franse tamarisk & Tamarix gallica & 23 & 1 & 0 & 0 & 1 \\
\hline Vaatplanten & Moerascipres & Taxodium distichum & 23 & 1 & 0 & 0 & 1 \\
\hline Vaatplanten & Franjekelk & Tellima grandiflora & 23 & 1 & 0 & 0 & 1 \\
\hline Vaatplanten & Halsbloem & Trachelium caeruleum & 23 & 1 & 0 & 0 & 1 \\
\hline Vaatplanten & Bochtige klaver & Trifolium medium & 23 & 1 & 0 & 0 & 1 \\
\hline Vaatplanten & Doffe ereprijs & Veronica opaca & 23 & 1 & 0 & 0 & 1 \\
\hline Vaatplanten & Slangenlook & Allium scorodoprasum & 22 & 1 & 0 & 1 & 1 \\
\hline Vaatplanten & Grote hardvrucht & Bunias orientalis & 22 & 1 & 0 & 1 & 1 \\
\hline Vaatplanten & Stomphoekig sterrenkroos & Callitriche obtusangula & 22 & 1 & 0 & 1 & 1 \\
\hline
\end{tabular}




\begin{tabular}{|c|c|c|c|c|c|c|c|}
\hline srtgroepen & soort_ned & soort_wet & not & \multicolumn{3}{|c|}{ vr na vr+na } & a vr-na \\
\hline Vaatplanten & Hazenzegge & Carex ovalis & 22 & 1 & 0 & 1 & 1 \\
\hline Vaatplanten & Rankende helmbloem & Ceratocapnos claviculata & 22 & 1 & 0 & 1 & 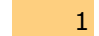 \\
\hline Vaatplanten & Tweestijlige meidoorn & Crataegus laevigata & 22 & 1 & 0 & 1 & 1 \\
\hline Vaatplanten & Wit hongerbloempje & Draba muralis & 22 & 1 & 0 & 1 & 1 \\
\hline Vaatplanten & Boekweit & Fagopyrum esculentum & 22 & 1 & 0 & 1 & 1 \\
\hline Vaatplanten & Fijne ooievaarsbek & Geranium columbinum & 22 & 1 & 0 & 1 & 1 \\
\hline Vaatplanten & Muizenoor & Hieracium pilosella & 22 & 1 & 0 & 1 & 1 \\
\hline Vaatplanten & Tripmadam & Sedum rupestre & 22 & 1 & 0 & 1 & 1 \\
\hline Vaatplanten & Heggenvogelmuur & Stellaria neglecta & 22 & 1 & 0 & 1 & 1 \\
\hline Vaatplanten & Graskers & Lepidium graminifolium & 21 & 1 & 0 & 2 & 1 \\
\hline Vaatplanten & Smal vlieszaad & Corispermum intermedium & 19 & 1 & 0 & 4 & 1 \\
\hline Vaatplanten & Zwarte zegge & Carex nigra & 21 & 2 & 1 & 0 & 1 \\
\hline Vaatplanten & Brede waterpest & Elodea canadensis & 21 & 2 & 1 & 0 & 1 \\
\hline Vaatplanten & Fijn schapengras & Festuca filiformis & 21 & 2 & 1 & 0 & 1 \\
\hline Vaatplanten & Ruig hertshooi & Hypericum hirsutum & 21 & 2 & 1 & 0 & 1 \\
\hline Vaatplanten & Eendenkroos & Lemna sp. indet. & 21 & 2 & 1 & 0 & 1 \\
\hline Vaatplanten & Framboos & Rubus idaeus & 21 & 2 & 1 & 0 & 1 \\
\hline Vaatplanten & Zweedse lijsterbes & Sorbus intermedia & 21 & 2 & 1 & 0 & 1 \\
\hline Vaatplanten & Sneeuwbes & Symphoricarpos albus & 21 & 2 & 1 & 0 & 1 \\
\hline Vaatplanten & Grote tijm & Thymus pulegioides & 21 & 2 & 1 & 0 & 1 \\
\hline Vaatplanten & Hollandse linde & Tilia $x$ vulgaris & 21 & 2 & 1 & 0 & 1 \\
\hline Vaatplanten & Gevleugeld hertshooi & Hypericum tetrapterum & 20 & 2 & 1 & 1 & 1 \\
\hline Vaatplanten & Pijlkruidkers & Lepidium draba & 20 & 2 & 1 & 1 & 1 \\
\hline Vaatplanten & Middelste teunisbloem & Oenothera biennis & 20 & 2 & 1 & 1 & 1 \\
\hline Vaatplanten & Rivierkruiskruid & Senecio sarracenicus & 20 & 2 & 1 & 1 & 1 \\
\hline Vaatplanten & Bosmuur & Stellaria nemorum & 20 & 2 & 1 & 1 & 1 \\
\hline Vaatplanten & Grote centaurie & Centaurea scabiosa & 19 & 2 & 1 & 2 & 1 \\
\hline Vaatplanten & Zachte haver & Helictotrichon pubescens & 19 & 2 & 1 & 2 & 1 \\
\hline Vaatplanten & Bloedzuring & Rumex sanguineus & 19 & 2 & 1 & 2 & 1 \\
\hline Vaatplanten & Bieslook & Allium schoenoprasum & 18 & 2 & 1 & 3 & 1 \\
\hline Vaatplanten & Knikkende distel & Carduus nutans & 16 & 2 & 1 & 5 & 1 \\
\hline Vaatplanten & Sikkelklaver & Medicago falcata & 14 & 2 & 1 & 7 & 1 \\
\hline Vaatplanten & Gewoon sterrenkroos & Callitriche platycarpa & 19 & 3 & 2 & 0 & 1 \\
\hline Vaatplanten & Voszegge & Carex vulpina & 19 & 3 & 2 & 0 & 1 \\
\hline Vaatplanten & Ronde ooievaarsbek & Geranium rotundifolium & 19 & 3 & 2 & 0 & 1 \\
\hline Vaatplanten & Biezenknoppen & Juncus conglomeratus & 19 & 3 & 2 & 0 & 1 \\
\hline Vaatplanten & Amerikaanse eik & Quercus rubra & 19 & 3 & 2 & 0 & 1 \\
\hline Vaatplanten & Kruisbladige wolfsmelk & Euphorbia lathyris & 18 & 3 & 2 & 1 & 1 \\
\hline Vaatplanten & Moeraskruiskruid & Jacobaea paludosa & 15 & 3 & 2 & 4 & 1 \\
\hline Vaatplanten & Ruw vergeet-mij-nietje & Myosotis ramosissima & 17 & 4 & 3 & 0 & 1 \\
\hline Vaatplanten & Kruipend zenegroen & Ajuga reptans & 16 & 4 & 3 & 1 & 1 \\
\hline Vaatplanten & Lidrus & Equisetum palustre & 12 & 4 & 3 & 5 & 1 \\
\hline Vaatplanten & Engelse alant & Inula britannica & 10 & 4 & 3 & 7 & 1 \\
\hline Vaatplanten & Veldzuring & Rumex acetosa & 9 & 4 & 3 & 8 & 1 \\
\hline Vaatplanten & Bijvoet & Artemisia vulgaris & 5 & 4 & 3 & 12 & 1 \\
\hline Vaatplanten & Kruldistel & Carduus crispus & 5 & 4 & 3 & 12 & 1 \\
\hline Vaatplanten & Hondsroos & Rosa canina & 12 & 5 & 4 & 3 & 1 \\
\hline Vaatplanten & Ruw beemdgras & Poa trivialis & 6 & 5 & 4 & 9 & 1 \\
\hline Vaatplanten & Dauwbraam & Rubus caesius & 6 & 5 & 4 & 9 & 1 \\
\hline Vaatplanten & Smalle wikke & Vicia sativa subsp. nigra & 10 & 7 & 6 & 1 & 1 \\
\hline Vaatplanten & Rietgras & Phalaris arundinacea & 2 & 7 & 6 & 9 & 1 \\
\hline Vaatplanten & Gewone ossentong & Anchusa officinalis & 23 & 0 & 0 & 1 & 0 \\
\hline Vaatplanten & Torenkruid & Arabis glabra & 23 & 0 & 0 & 1 & 0 \\
\hline Vaatplanten & Japanse berberis & Berberis thunbergii & 23 & 0 & 0 & 1 & 0 \\
\hline Vaatplanten & Groene bermzegge & Carex divulsa & 23 & 0 & 0 & 1 & 0 \\
\hline Vaatplanten & Rivierduinzegge & Carex ligerica & 23 & 0 & 0 & 1 & 0 \\
\hline Vaatplanten & Slanke zegge & Carex strigosa & 23 & 0 & 0 & 1 & 0 \\
\hline Vaatplanten & Boszegge & Carex sylvatica & 23 & 0 & 0 & 1 & 0 \\
\hline Vaatplanten & Esdoornganzenvoet & Chenopodium hybridum & 23 & 0 & 0 & 1 & 0 \\
\hline Vaatplanten & Verspreidbladig goudveil & Chrysosplenium alternifolium & 23 & 0 & 0 & 1 & 0 \\
\hline Vaatplanten & Paarbladig goudveil & Chrysosplenium oppositifolium & 23 & 0 & 0 & 1 & 0 \\
\hline Vaatplanten & Herfsttijloos & Colchicum autumnale & 23 & 0 & 0 & 1 & 0 \\
\hline Vaatplanten & Droogbloeier & Colchicum byzantinum & 23 & 0 & 0 & 1 & 0 \\
\hline Vaatplanten & Moerasstreepzaad & Crepis paludosa & 23 & 0 & 0 & 1 & 0 \\
\hline
\end{tabular}




\begin{tabular}{|c|c|c|c|c|c|c|c|}
\hline srtgroepen & soort_ned & soort_wet & not & vr & la & +nz: & vr-na \\
\hline Vaatplanten & Veldhondstong & Cynoglossum officinale & 23 & 0 & 0 & 1 & 0 \\
\hline Vaatplanten & Hartbladzonnebloem & Doronicum pardalianches & 23 & 0 & 0 & 1 & 0 \\
\hline Vaatplanten & Vertakte paardenstaart & Equisetum ramosissimum & 23 & 0 & 0 & 1 & 0 \\
\hline Vaatplanten & Vertakt schaafstro & Equisetum $\mathrm{x}$ moorei & 23 & 0 & 0 & 1 & 0 \\
\hline Vaatplanten & Stijve steenraket & Erysimum virgatum & 23 & 0 & 0 & 1 & 0 \\
\hline Vaatplanten & Sachalinse duizendknoop & Fallopia sachalinensis & 23 & 0 & 0 & 1 & 0 \\
\hline Vaatplanten & Gespleten / Gewone hennepnetel & Galeopsis bifida/tetrahit & 23 & 0 & 0 & 1 & 0 \\
\hline Vaatplanten & Ruw walstro & Galium uliginosum & 23 & 0 & 0 & 1 & 0 \\
\hline Vaatplanten & Weidehavikskruid & Hieracium caespitosum & 23 & 0 & 0 & 1 & 0 \\
\hline Vaatplanten & Gifsla & Lactuca virosa & 23 & 0 & 0 & 1 & 0 \\
\hline Vaatplanten & Ruige veldbies & Luzula pilosa & 23 & 0 & 0 & 1 & 0 \\
\hline Vaatplanten & Boswederik & Lysimachia nemorum & 23 & 0 & 0 & 1 & 0 \\
\hline Vaatplanten & Moeraswederik & Lysimachia thyrsiflora & 23 & 0 & 0 & 1 & 0 \\
\hline Vaatplanten & Eenbloemig parelgras & Melica uniflora & 23 & 0 & 0 & 1 & 0 \\
\hline Vaatplanten & Bosbingelkruid & Mercurialis perennis & 23 & 0 & 0 & 1 & 0 \\
\hline Vaatplanten & Groot bronkruid & Montia fontana & 23 & 0 & 0 & 1 & 0 \\
\hline Vaatplanten & Langbladige druifhyacint & Muscari armeniacum & 23 & 0 & 0 & 1 & 0 \\
\hline Vaatplanten & Bastaardteunisbloem & Oenothera $x$ fallax & 23 & 0 & 0 & 1 & 0 \\
\hline Vaatplanten & Esparcette & Onobrychis viciifolia & 23 & 0 & 0 & 1 & 0 \\
\hline Vaatplanten & Walstrobremraap & Orobanche caryophyllacea & 23 & 0 & 0 & 1 & 0 \\
\hline Vaatplanten & Rode bremraap & Orobanche lutea & 23 & 0 & 0 & 1 & 0 \\
\hline Vaatplanten & Witte klaverzuring & Oxalis acetosella & 23 & 0 & 0 & 1 & 0 \\
\hline Vaatplanten & Pluimgierst & Panicum miliaceum & 23 & 0 & 0 & 1 & 0 \\
\hline Vaatplanten & Eenbes & Paris quadrifolia & 23 & 0 & 0 & 1 & 0 \\
\hline Vaatplanten & Slanke sleutelbloem & Primula elatior & 23 & 0 & 0 & 1 & 0 \\
\hline Vaatplanten & Heelkruid & Sanicula europaea & 23 & 0 & 0 & 1 & 0 \\
\hline Vaatplanten & Duifkruid & Scabiosa columbaria & 23 & 0 & 0 & 1 & 0 \\
\hline Vaatplanten & Chinese naaldaar & Setaria faberi & 23 & 0 & 0 & 1 & 0 \\
\hline Vaatplanten & Fladderiep & Ulmus laevis & 23 & 0 & 0 & 1 & 0 \\
\hline Vaatplanten & Bosereprijs & Veronica montana & 23 & 0 & 0 & 1 & 0 \\
\hline Vaatplanten & Stijve wikke & Vicia tenuifolia & 23 & 0 & 0 & 1 & 0 \\
\hline Vaatplanten & Donkersporig bosviooltje & Viola reichenbachiana & 23 & 0 & 0 & 1 & 0 \\
\hline Vaatplanten & Daslook & Allium ursinum & 22 & 0 & 0 & 2 & 0 \\
\hline Vaatplanten & Bevertjes & Briza media & 22 & 0 & 0 & 2 & 0 \\
\hline Vaatplanten & Drienerfmuur & Moehringia trinervia & 22 & 0 & 0 & 2 & 0 \\
\hline Vaatplanten & Adderwortel & Persicaria bistorta & 22 & 0 & 0 & 2 & 0 \\
\hline Vaatplanten & Brede stekelvaren & Dryopteris dilatata & 21 & 0 & 0 & 3 & 0 \\
\hline Vaatplanten & Kleine ruit & Thalictrum minus & 21 & 0 & 0 & 3 & 0 \\
\hline Vaatplanten & Brede ereprijs & Veronica austriaca subsp. teucrium & 21 & 0 & 0 & 3 & 0 \\
\hline Vaatplanten & Agrimonie & Agrimonia eupatoria & 22 & 1 & 1 & 0 & 0 \\
\hline Vaatplanten & Vroege haver & Aira praecox & 22 & 1 & 1 & 0 & 0 \\
\hline Vaatplanten & Fraaie vrouwenmantel & Alchemilla mollis & 22 & 1 & 1 & 0 & 0 \\
\hline Vaatplanten & Haver & Avena sativa & 22 & 1 & 1 & 0 & 0 \\
\hline Vaatplanten & Biet s.l. & Beta vulgaris & 22 & 1 & 1 & 0 & 0 \\
\hline Vaatplanten & Zachte berk & Betula pubescens & 22 & 1 & 1 & 0 & 0 \\
\hline Vaatplanten & Kool & Brassica oleracea-cultivars & 22 & 1 & 1 & 0 & 0 \\
\hline Vaatplanten & Prachtklokje & Campanula persicifolia & 22 & 1 & 1 & 0 & 0 \\
\hline Vaatplanten & Pilzegge & Carex pilulifera & 22 & 1 & 1 & 0 & 0 \\
\hline Vaatplanten & Snavelzegge & Carex rostrata & 22 & 1 & 1 & 0 & 0 \\
\hline Vaatplanten & Tamme kastanje & Castanea sativa & 22 & 1 & 1 & 0 & 0 \\
\hline Vaatplanten & Viltige hoornbloem & Cerastium tomentosum & 22 & 1 & 1 & 0 & 0 \\
\hline Vaatplanten & Gekielde dravik & Ceratochloa carinata & 22 & 1 & 1 & 0 & 0 \\
\hline Vaatplanten & Buntgras & Corynephorus canescens & 22 & 1 & 1 & 0 & 0 \\
\hline Vaatplanten & Cosmos & Cosmos bipinnatus & 22 & 1 & 1 & 0 & 0 \\
\hline Vaatplanten & Meloen & Cucumis melo & 22 & 1 & 1 & 0 & 0 \\
\hline Vaatplanten & Cyrtomium & Cyrtomium fortunei & 22 & 1 & 1 & 0 & 0 \\
\hline Vaatplanten & Rietorchis & Dactylorhiza majalis subsp. praetermissa & 22 & 1 & 1 & 0 & 0 \\
\hline Vaatplanten & Bochtige smele & Deschampsia flexuosa & 22 & 1 & 1 & 0 & 0 \\
\hline Vaatplanten & Klein robertskruid & Geranium purpureum & 22 & 1 & 1 & 0 & 0 \\
\hline Vaatplanten & Stomp vlotgras & Glyceria notata & 22 & 1 & 1 & 0 & 0 \\
\hline Vaatplanten & Wilde hyacint & Hyacinthoides non-scripta & 22 & 1 & 1 & 0 & 0 \\
\hline Vaatplanten & Wilde $\times$ Spaanse hyacint & Hyacinthoides $x$ massartiana & 22 & 1 & 1 & 0 & 0 \\
\hline Vaatplanten & Bilzekruid & Hyoscyamus niger & 22 & 1 & 1 & 0 & 0 \\
\hline Vaatplanten & Donderkruid & Inula conyzae & 22 & 1 & 1 & 0 & 0 \\
\hline
\end{tabular}




\begin{tabular}{|c|c|c|c|c|c|c|c|}
\hline srtgroepen & soort_ned & soort_wet & not & vr & a & $+n$ & vr-na \\
\hline Vaatplanten & Waterkruiskruid & Jacobaea aquatica & 22 & 1 & 1 & 0 & 0 \\
\hline Vaatplanten & Knopkroos & Lemna turionifera & 22 & 1 & 1 & 0 & 0 \\
\hline Vaatplanten & Puntwederik & Lysimachia punctata & 22 & 1 & 1 & 0 & 0 \\
\hline Vaatplanten & Kleine rupsklaver & Medicago minima & 22 & 1 & 1 & 0 & 0 \\
\hline Vaatplanten & Distelbremraap & Orobanche reticulata & 22 & 1 & 1 & 0 & 0 \\
\hline Vaatplanten & Phacelia & Phacelia tanacetifolia & 22 & 1 & 1 & 0 & 0 \\
\hline Vaatplanten & Kanariezaad & Phalaris canariensis & 22 & 1 & 1 & 0 & 0 \\
\hline Vaatplanten & Klein timoteegras & Phleum pratense subsp. serotinum & 22 & 1 & 1 & 0 & 0 \\
\hline Vaatplanten & Echte lampionplant & Physalis alkekengi & 22 & 1 & 1 & 0 & 0 \\
\hline Vaatplanten & Trosgierst & Setaria italica & 22 & 1 & 1 & 0 & 0 \\
\hline Vaatplanten & Prikneus & Silene coronaria & 22 & 1 & 1 & 0 & 0 \\
\hline Vaatplanten & Witte mosterd & Sinapis alba & 22 & 1 & 1 & 0 & 0 \\
\hline Vaatplanten & Moerasmelkdistel & Sonchus palustris & 22 & 1 & 1 & 0 & 0 \\
\hline Vaatplanten & Akkerandoorn & Stachys arvensis & 22 & 1 & 1 & 0 & 0 \\
\hline Vaatplanten & Sering & Syringa vulgaris & 22 & 1 & 1 & 0 & 0 \\
\hline Vaatplanten & Perzische klaver & Trifolium resupinatum & 22 & 1 & 1 & 0 & 0 \\
\hline Vaatplanten & Keizerskaars & Verbascum phlomoides & 22 & 1 & 1 & 0 & 0 \\
\hline Vaatplanten & Muskuskruid & Adoxa moschatellina & 21 & 1 & 1 & 1 & 0 \\
\hline Vaatplanten & Reuzenzwenkgras & Festuca gigantea & 21 & 1 & 1 & 1 & 0 \\
\hline Vaatplanten & Stijf havikskruid & Hieracium laevigatum & 21 & 1 & 1 & 1 & 0 \\
\hline Vaatplanten & Zilte greppelrus & Juncus ambiguus & 21 & 1 & 1 & 1 & 0 \\
\hline Vaatplanten & Walstroleeuwenbek & Linaria purpurea & 21 & 1 & 1 & 1 & 0 \\
\hline Vaatplanten & Polei & Mentha pulegium & 21 & 1 & 1 & 1 & 0 \\
\hline Vaatplanten & Spaanse zuring & Rumex scutatus & 21 & 1 & 1 & 1 & 0 \\
\hline Vaatplanten & Veldsalie & Salvia pratensis & 21 & 1 & 1 & 1 & 0 \\
\hline Vaatplanten & Grote muur & Stellaria holostea & 21 & 1 & 1 & 1 & 0 \\
\hline Vaatplanten & Klein tasjeskruid & Teesdalia nudicaulis & 21 & 1 & 1 & 1 & 0 \\
\hline Vaatplanten & Eekhoorngras & Vulpia bromoides & 21 & 1 & 1 & 1 & 0 \\
\hline Vaatplanten & Grijskruid & Berteroa incana & 20 & 1 & 1 & 2 & 0 \\
\hline Vaatplanten & Kweekdravik & Bromopsis inermis subsp. inermis & 20 & 1 & 1 & 2 & 0 \\
\hline Vaatplanten & Wilde kamperfoelie & Lonicera periclymenum & 20 & 1 & 1 & 2 & 0 \\
\hline Vaatplanten & Stijve waterranonkel & Ranunculus circinatus & 20 & 1 & 1 & 2 & 0 \\
\hline Vaatplanten & Egelantier & Rosa rubiginosa & 20 & 1 & 1 & 2 & 0 \\
\hline Vaatplanten & Kleverig kruiskruid & Senecio viscosus & 20 & 1 & 1 & 2 & 0 \\
\hline Vaatplanten & Weidekervel & Silaum silaus & 20 & 1 & 1 & 2 & 0 \\
\hline Vaatplanten & Springzaadveldkers & Cardamine impatiens & 19 & 1 & 1 & 3 & 0 \\
\hline Vaatplanten & Druifkruid & Chenopodium botrys & 19 & 1 & 1 & 3 & 0 \\
\hline Vaatplanten & Slanke waterkers & Nasturtium microphyllum & 19 & 1 & 1 & 3 & 0 \\
\hline Vaatplanten & Kruipend stalkruid & Ononis repens subsp. repens & 19 & 1 & 1 & 3 & 0 \\
\hline Vaatplanten & Plat beemdgras & Poa compressa & 19 & 1 & 1 & 3 & 0 \\
\hline Vaatplanten & Glansbesnachtschade & Solanum physalifolium & 18 & 1 & 1 & 4 & 0 \\
\hline Vaatplanten & Liggende ganzerik & Potentilla supina & 17 & 1 & 1 & 5 & 0 \\
\hline Vaatplanten & Vijgenboom & Ficus carica & 20 & 2 & 2 & 0 & 0 \\
\hline Vaatplanten & Ruige klaproos & Papaver argemone & 20 & 2 & 2 & 0 & 0 \\
\hline Vaatplanten & Zacht loogkruid & Salsola tragus & 20 & 2 & 2 & 0 & 0 \\
\hline Vaatplanten & Schijnraket & Erucastrum gallicum & 19 & 2 & 2 & 1 & 0 \\
\hline Vaatplanten & Spiesleeuwenbek & Kickxia elatine & 19 & 2 & 2 & 1 & 0 \\
\hline Vaatplanten & Bonte gele dovenetel & Lamiastrum galeobdolon subsp. argentatum & 19 & 2 & 2 & 1 & 0 \\
\hline Vaatplanten & Grote pimpernel & Sanguisorba officinalis & 19 & 2 & 2 & 1 & 0 \\
\hline Vaatplanten & Gevlekte aronskelk & Arum maculatum & 18 & 2 & 2 & 2 & 0 \\
\hline Vaatplanten & Groot heksenkruid & Circaea lutetiana & 18 & 2 & 2 & 2 & 0 \\
\hline Vaatplanten & Ruige leeuwentand & Leontodon hispidus & 18 & 2 & 2 & 2 & 0 \\
\hline Vaatplanten & Zandweegbree & Plantago arenaria & 18 & 2 & 2 & 2 & 0 \\
\hline Vaatplanten & Gulden sleutelbloem & Primula veris & 18 & 2 & 2 & 2 & 0 \\
\hline Vaatplanten & Grote watereppe & Sium latifolium & 18 & 2 & 2 & 2 & 0 \\
\hline Vaatplanten & Kalmoes & Acorus calamus & 17 & 2 & 2 & 3 & 0 \\
\hline Vaatplanten & Watergentiaan & Nymphoides peltata & 15 & 2 & 2 & 5 & 0 \\
\hline Vaatplanten & Gewone dotterbloem & Caltha palustris subsp. palustris & 17 & 3 & 3 & 1 & 0 \\
\hline Vaatplanten & Wollige munt & Mentha $\mathrm{x}$ rotundifolia & 17 & 3 & 3 & 1 & 0 \\
\hline Vaatplanten & Klein glaskruid & Parietaria judaica & 17 & 3 & 3 & 1 & 0 \\
\hline Vaatplanten & Rechte ganzerik & Potentilla recta & 17 & 3 & 3 & 1 & 0 \\
\hline Vaatplanten & Gevleugeld helmkruid & Scrophularia umbrosa & 16 & 3 & 3 & 2 & 0 \\
\hline Vaatplanten & Hoog struisgras & Agrostis gigantea & 15 & 3 & 3 & 3 & 0 \\
\hline Vaatplanten & Bittere wilg & Salix purpurea & 15 & 3 & 3 & 3 & 0 \\
\hline
\end{tabular}




\begin{tabular}{|c|c|c|c|c|c|c|c|}
\hline srtgroepen & soort_ned & soort_wet & not & \multicolumn{4}{|c|}{ vr na vr+na vr-na } \\
\hline Vaatplanten & Grasmuur & Stellaria graminea & 15 & 3 & 3 & 3 & 0 \\
\hline Vaatplanten & Smalle waterpest & Elodea nuttallii & 8 & 3 & 3 & 10 & 0 \\
\hline Vaatplanten & Akkervergeet-mij-nietje & Myosotis arvensis & 15 & 4 & 4 & 1 & 0 \\
\hline Vaatplanten & Kleine egelskop & Sparganium emersum & 15 & 4 & 4 & 1 & 0 \\
\hline Vaatplanten & Heen & Bolboschoenus maritimus & 12 & 4 & 4 & 4 & 0 \\
\hline Vaatplanten & Kaal breukkruid & Herniaria glabra & 11 & 4 & 4 & 5 & 0 \\
\hline Vaatplanten & Gewone steenraket & Erysimum cheiranthoides & 10 & 4 & 4 & 6 & 0 \\
\hline Vaatplanten & Timoteegras & Phleum pratense subsp. pratense & 7 & 4 & 4 & 9 & 0 \\
\hline Vaatplanten & Vogelwikke & Vicia cracca & 3 & 4 & 4 & 13 & 0 \\
\hline Vaatplanten & Rode klaver & Trifolium pratense & 1 & 4 & 4 & 15 & 0 \\
\hline Vaatplanten & Kleine bevernel & Pimpinella saxifraga & 10 & 5 & 5 & 4 & 0 \\
\hline Vaatplanten & Knolboterbloem & Ranunculus bulbosus & 6 & 5 & 5 & 8 & 0 \\
\hline Vaatplanten & Vogelmuur & Stellaria media & 6 & 5 & 5 & 8 & 0 \\
\hline Vaatplanten & Kweek & Elytrigia repens & 4 & 5 & 5 & 10 & 0 \\
\hline Vaatplanten & Kooltje-vuur & Adonis flammea & 23 & 0 & 1 & 0 & -1 \\
\hline Vaatplanten & Zilverhaver & Aira caryophyllea & 23 & 0 & 1 & 0 & -1 \\
\hline Vaatplanten & Slanke/Grote waterweegbree & Alisma lanceolatum/plantago-aquatica & 23 & 0 & 1 & 0 & -1 \\
\hline Vaatplanten & Heemst & Althaea officinalis & 23 & 0 & 1 & 0 & -1 \\
\hline Vaatplanten & Kleinbloemige amsinckia & Amsinckia micrantha & 23 & 0 & 1 & 0 & -1 \\
\hline Vaatplanten & Wondklaver & Anthyllis vulneraria & 23 & 0 & 1 & 0 & -1 \\
\hline Vaatplanten & Italiaanse aronskelk & Arum italicum & 23 & 0 & 1 & 0 & -1 \\
\hline Vaatplanten & Herfstaster & Aster $\mathrm{x}$ versicolor & 23 & 0 & 1 & 0 & -1 \\
\hline Vaatplanten & Wolfskers & Atropa bella-donna & 23 & 0 & 1 & 0 & -1 \\
\hline Vaatplanten & Oot & Avena fatua & 23 & 0 & 1 & 0 & -1 \\
\hline Vaatplanten & Dreps & Bromus secalinus & 23 & 0 & 1 & 0 & -1 \\
\hline Vaatplanten & Buxus & Buxus sempervirens & 23 & 0 & 1 & 0 & -1 \\
\hline Vaatplanten & Zeeraket & Cakile maritima & 23 & 0 & 1 & 0 & -1 \\
\hline Vaatplanten & Gevleugeld sterrenkroos & Callitriche stagnalis & 23 & 0 & 1 & 0 & -1 \\
\hline Vaatplanten & Weideklokje & Campanula patula & 23 & 0 & 1 & 0 & -1 \\
\hline Vaatplanten & Kruipklokje & Campanula poscharskyana & 23 & 0 & 1 & 0 & -1 \\
\hline Vaatplanten & Bolletjeskers & Cardamine bulbifera & 23 & 0 & 1 & 0 & -1 \\
\hline Vaatplanten & Stijve zegge & Carex elata & 23 & 0 & 1 & 0 & -1 \\
\hline Vaatplanten & Bleke zegge & Carex pallescens & 23 & 0 & 1 & 0 & -1 \\
\hline Vaatplanten & Valse zandzegge & Carex reichenbachii & 23 & 0 & 1 & 0 & -1 \\
\hline Vaatplanten & Bergcentaurie & Centaurea montana & 23 & 0 & 1 & 0 & -1 \\
\hline Vaatplanten & Marjoleinbekje & Chaenorhinum origanifolium & 23 & 0 & 1 & 0 & -1 \\
\hline Vaatplanten & Californische cipres & Chamaecyparis lawsoniana & 23 & 0 & 1 & 0 & -1 \\
\hline Vaatplanten & Grote sneeuwroem & Chionodoxa forbesii / lucillae & 23 & 0 & 1 & 0 & -1 \\
\hline Vaatplanten & Knikbloem & Chondrilla juncea & 23 & 0 & 1 & 0 & -1 \\
\hline Vaatplanten & Moesdistel & Cirsium oleraceum & 23 & 0 & 1 & 0 & -1 \\
\hline Vaatplanten & Roze winterpostelein & Claytonia sibirica & 23 & 0 & 1 & 0 & -1 \\
\hline Vaatplanten & Muurbloemmosterd & Coincya monensis & 23 & 0 & 1 & 0 & -1 \\
\hline Vaatplanten & Wilde ridderspoor & Consolida regalis & 23 & 0 & 1 & 0 & -1 \\
\hline Vaatplanten & Dagschone & Convolvulus tricolor & 23 & 0 & 1 & 0 & -1 \\
\hline Vaatplanten & Gele kornoelje & Cornus mas & 23 & 0 & 1 & 0 & -1 \\
\hline Vaatplanten & Watercrassula & Crassula helmsii & 23 & 0 & 1 & 0 & -1 \\
\hline Vaatplanten & Boerenkrokus & Crocus tommasinianus & 23 & 0 & 1 & 0 & -1 \\
\hline Vaatplanten & Komkommer & Cucumis sativus & 23 & 0 & 1 & 0 & -1 \\
\hline Vaatplanten & Sierpompoen & Cucurbita pepo & 23 & 0 & 1 & 0 & -1 \\
\hline Vaatplanten & Oeverwarkruid & Cuscuta gronovii & 23 & 0 & 1 & 0 & -1 \\
\hline Vaatplanten & Cynoglossum & Cynoglossum amabile & 23 & 0 & 1 & 0 & -1 \\
\hline Vaatplanten & Knolcyperus & Cyperus esculentus & 23 & 0 & 1 & 0 & -1 \\
\hline Vaatplanten & Rood cypergras & Cyperus longus & 23 & 0 & 1 & 0 & -1 \\
\hline Vaatplanten & IJle kropaar & Dactylis polygama & 23 & 0 & 1 & 0 & -1 \\
\hline Vaatplanten & Kleine zandkool & Diplotaxis muralis & 23 & 0 & 1 & 0 & -1 \\
\hline Vaatplanten & Geschubde mannetjesvaren & Dryopteris affinis & 23 & 0 & 1 & 0 & -1 \\
\hline Vaatplanten & Eivormige waterbies & Eleocharis ovata & 23 & 0 & 1 & 0 & -1 \\
\hline Vaatplanten & Donkergroene basterdwederik & Epilobium obscurum & 23 & 0 & 1 & 0 & -1 \\
\hline Vaatplanten & Bleke basterdwederik & Epilobium roseum & 23 & 0 & 1 & 0 & -1 \\
\hline Vaatplanten & Stinkend liefdegras & Eragrostis cilianensis & 23 & 0 & 1 & 0 & -1 \\
\hline Vaatplanten & Zwaardherik & Eruca vesicaria & 23 & 0 & 1 & 0 & -1 \\
\hline Vaatplanten & Euphorbia & Euphorbia lucida & 23 & 0 & 1 & 0 & -1 \\
\hline Vaatplanten & Euphorbia myrsinites & Euphorbia myrsinites & 23 & 0 & 1 & 0 & -1 \\
\hline atplante & jve wolfsmelk & uphorbia stricta & 23 & 0 & 1 & 0 & -1 \\
\hline
\end{tabular}




\begin{tabular}{|c|c|c|c|c|c|c|c|}
\hline srtgroepen & soort_ned & soort_wet & not & vr & na & $+n$ & a vr-na \\
\hline Vaatplanten & Bosgeelster & Gagea lutea & 23 & 0 & 1 & 0 & -1 \\
\hline Vaatplanten & Getand vlotgras & Glyceria declinata & 23 & 0 & 1 & 0 & -1 \\
\hline Vaatplanten & Paarbladig fonteinkruid & Groenlandia densa & 23 & 0 & 1 & 0 & -1 \\
\hline Vaatplanten & Duindoorn & Hippophae rhamnoides & 23 & 0 & 1 & 0 & -1 \\
\hline Vaatplanten & Spaanse hyacint & Hyacinthoides hispanica & 23 & 0 & 1 & 0 & -1 \\
\hline Vaatplanten & Hyacint & Hyacinthus orientalis & 23 & 0 & 1 & 0 & -1 \\
\hline Vaatplanten & Tweekleurig springzaad & Impatiens balfourii & 23 & 0 & 1 & 0 & -1 \\
\hline Vaatplanten & Juncus & Juncus imbricatus & 23 & 0 & 1 & 0 & -1 \\
\hline Vaatplanten & Graslathyrus & Lathyrus nissolia & 23 & 0 & 1 & 0 & -1 \\
\hline Vaatplanten & Lavendel & Lavandula angustifolia & 23 & 0 & 1 & 0 & -1 \\
\hline Vaatplanten & Lavatera & Lavatera thuringiaca & 23 & 0 & 1 & 0 & -1 \\
\hline Vaatplanten & Groot spiegelklokje & Legousia speculum-veneris & 23 & 0 & 1 & 0 & -1 \\
\hline Vaatplanten & Linum & Linum grandiflorum & 23 & 0 & 1 & 0 & -1 \\
\hline Vaatplanten & Zilverschildzaad & Lobularia maritima & 23 & 0 & 1 & 0 & -1 \\
\hline Vaatplanten & Lonicera & Lonicera nitida & 23 & 0 & 1 & 0 & -1 \\
\hline Vaatplanten & Rode kamperfoelie & Lonicera xylosteum & 23 & 0 & 1 & 0 & -1 \\
\hline Vaatplanten & Waterteunisbloem & Ludwigia grandiflora & 23 & 0 & 1 & 0 & -1 \\
\hline Vaatplanten & Grote veldbies & Luzula sylvatica & 23 & 0 & 1 & 0 & -1 \\
\hline Vaatplanten & Malus & Malus domestica & 23 & 0 & 1 & 0 & -1 \\
\hline Vaatplanten & Wilde appel & Malus sylvestris s.s. & 23 & 0 & 1 & 0 & -1 \\
\hline Vaatplanten & Struisvaren & Matteuccia struthiopteris & 23 & 0 & 1 & 0 & -1 \\
\hline Vaatplanten & Kleine honingklaver & Melilotus indicus & 23 & 0 & 1 & 0 & -1 \\
\hline Vaatplanten & Edelmunt & Mentha $x$ gracilis & 23 & 0 & 1 & 0 & -1 \\
\hline Vaatplanten & Mimulus & Mimulus ringens & 23 & 0 & 1 & 0 & -1 \\
\hline Vaatplanten & Blauwe druifjes & Muscari botryoides & 23 & 0 & 1 & 0 & -1 \\
\hline Vaatplanten & Muscari latifolium & Muscari latifolium & 23 & 0 & 1 & 0 & -1 \\
\hline Vaatplanten & Muizenstaart & Myosurus minimus & 23 & 0 & 1 & 0 & -1 \\
\hline Vaatplanten & Nemophila & Nemophila maculata & 23 & 0 & 1 & 0 & -1 \\
\hline Vaatplanten & Duinteunisbloem & Oenothera oakesiana & 23 & 0 & 1 & 0 & -1 \\
\hline Vaatplanten & Bolletjesvaren & Onoclea sensibilis & 23 & 0 & 1 & 0 & -1 \\
\hline Vaatplanten & Blauwe bremraap & Orobanche purpurea & 23 & 0 & 1 & 0 & -1 \\
\hline Vaatplanten & Panicum & Panicum barbipulvinatum & 23 & 0 & 1 & 0 & -1 \\
\hline Vaatplanten & Kale gierst & Panicum dichotomiflorum & 23 & 0 & 1 & 0 & -1 \\
\hline Vaatplanten & Groot glaskruid & Parietaria officinalis & 23 & 0 & 1 & 0 & -1 \\
\hline Vaatplanten & Persicaria amplexicaulis & Persicaria amplexicaulis & 23 & 0 & 1 & 0 & -1 \\
\hline Vaatplanten & Afghaanse duizendknoop & Persicaria wallichii & 23 & 0 & 1 & 0 & -1 \\
\hline Vaatplanten & Welriekende jasmijn & Philadelphus coronarius & 23 & 0 & 1 & 0 & -1 \\
\hline Vaatplanten & Westerse karmozijnbes & Phytolacca americana & 23 & 0 & 1 & 0 & -1 \\
\hline Vaatplanten & Erwt & Pisum sativum & 23 & 0 & 1 & 0 & -1 \\
\hline Vaatplanten & Poa & Poa infirma & 23 & 0 & 1 & 0 & -1 \\
\hline Vaatplanten & Kransmuur & Polycarpon tetraphyllum & 23 & 0 & 1 & 0 & -1 \\
\hline Vaatplanten & Zachte naaldvaren & Polystichum setiferum & 23 & 0 & 1 & 0 & -1 \\
\hline Vaatplanten & Zachte naaldvaren $x$ Stijve naaldvaren & Polystichum $x$ bicknellii & 23 & 0 & 1 & 0 & -1 \\
\hline Vaatplanten & Ontariopopulier & Populus balsamifera & 23 & 0 & 1 & 0 & -1 \\
\hline Vaatplanten & Zwarte balsempopulier & Populus trichocarpa & 23 & 0 & 1 & 0 & -1 \\
\hline Vaatplanten & Potentilla fruticosa & Potentilla fruticosa & 23 & 0 & 1 & 0 & -1 \\
\hline Vaatplanten & Middelste ganzerik & Potentilla intermedia & 23 & 0 & 1 & 0 & -1 \\
\hline Vaatplanten & Stomp kweldergras & Puccinellia distans subsp. distans & 23 & 0 & 1 & 0 & -1 \\
\hline Vaatplanten & Moseik & Quercus cerris & 23 & 0 & 1 & 0 & -1 \\
\hline Vaatplanten & Radijs & Raphanus sativus & 23 & 0 & 1 & 0 & -1 \\
\hline Vaatplanten & Witte reseda & Reseda alba & 23 & 0 & 1 & 0 & -1 \\
\hline Vaatplanten & Bosroos & Rosa arvensis & 23 & 0 & 1 & 0 & -1 \\
\hline Vaatplanten & Dijkviltbraam & Rubus armeniacus & 23 & 0 & 1 & 0 & -1 \\
\hline Vaatplanten & Japanse wijnbes & Rubus phoenicolasius & 23 & 0 & 1 & 0 & -1 \\
\hline Vaatplanten & Duitse dot & Salix dasyclados & 23 & 0 & 1 & 0 & -1 \\
\hline Vaatplanten & Kruipwilg & Salix repens & 23 & 0 & 1 & 0 & -1 \\
\hline Vaatplanten & Boswilg $\times$ Grauwe wilg & Salix $x$ reichardtii & 23 & 0 & 1 & 0 & -1 \\
\hline Vaatplanten & Grauwe wilg $\mathrm{x}$ Katwilg & Salix $x$ smithiana & 23 & 0 & 1 & 0 & -1 \\
\hline Vaatplanten & Chia & Salvia hispanica & 23 & 0 & 1 & 0 & -1 \\
\hline Vaatplanten & Bossalie & Salvia nemorosa & 23 & 0 & 1 & 0 & -1 \\
\hline Vaatplanten & Amerikaanse vlier & Sambucus canadensis & 23 & 0 & 1 & 0 & -1 \\
\hline Vaatplanten & Trosvlier & Sambucus racemosa & 23 & 0 & 1 & 0 & -1 \\
\hline Vaatplanten & Stekende bies & Schoenoplectus pungens & 23 & 0 & 1 & 0 & -1 \\
\hline Vaatplanten & Spaans vetkruid & Sedum hispanicum & 23 & 0 & 1 & 0 & -1 \\
\hline
\end{tabular}




\begin{tabular}{|c|c|c|c|c|c|c|c|}
\hline srtgroepen & soort_ned & soort_wet & not & vr & a & $+n$ & vr-na \\
\hline Vaatplanten & Roze hemelsleutel & Sedum spectabile & 23 & 0 & 1 & 0 & -1 \\
\hline Vaatplanten & Ruwe kransnaaldaar & Setaria verticilliformis & 23 & 0 & 1 & 0 & -1 \\
\hline Vaatplanten & Kegelsilene & Silene conica & 23 & 0 & 1 & 0 & -1 \\
\hline Vaatplanten & Nachtkoekoeksbloem & Silene noctiflora & 23 & 0 & 1 & 0 & -1 \\
\hline Vaatplanten & Solidago & Solidago rigida & 23 & 0 & 1 & 0 & -1 \\
\hline Vaatplanten & Echte guldenroede & Solidago virgaurea & 23 & 0 & 1 & 0 & -1 \\
\hline Vaatplanten & Spinazie & Spinacia oleracea & 23 & 0 & 1 & 0 & -1 \\
\hline Vaatplanten & Stachys $\mathrm{x}$ ambigua & Stachys $x$ ambigua & 23 & 0 & 1 & 0 & -1 \\
\hline Vaatplanten & Fijn vedergras & Stipa tenuissima & 23 & 0 & 1 & 0 & -1 \\
\hline Vaatplanten & Ruwe smeerwortel & Symphytum asperum & 23 & 0 & 1 & 0 & -1 \\
\hline Vaatplanten & Symphytum & Symphytum $\mathrm{x}$ hidcotense & 23 & 0 & 1 & 0 & -1 \\
\hline Vaatplanten & Akkerdoornzaad & Torilis arvensis & 23 & 0 & 1 & 0 & -1 \\
\hline Vaatplanten & Bleke morgenster & Tragopogon dubius & 23 & 0 & 1 & 0 & -1 \\
\hline Vaatplanten & Paarse morgenster & Tragopogon porrifolius & 23 & 0 & 1 & 0 & -1 \\
\hline Vaatplanten & Alexandrijnse klaver & Trifolium alexandrinum & 23 & 0 & 1 & 0 & -1 \\
\hline Vaatplanten & Tarwe & Triticum aestivum & 23 & 0 & 1 & 0 & -1 \\
\hline Vaatplanten & Koekruid & Vaccaria hispanica & 23 & 0 & 1 & 0 & -1 \\
\hline Vaatplanten & Melige toorts & Verbascum lychnitis & 23 & 0 & 1 & 0 & -1 \\
\hline Vaatplanten & Mannetjesereprijs & Veronica officinalis & 23 & 0 & 1 & 0 & -1 \\
\hline Vaatplanten & Schildereprijs & Veronica scutellata & 23 & 0 & 1 & 0 & -1 \\
\hline Vaatplanten & Wollige sneeuwbal & Viburnum lantana & 23 & 0 & 1 & 0 & -1 \\
\hline Vaatplanten & Viburnum rhytidophyllum & Viburnum rhytidophyllum & 23 & 0 & 1 & 0 & -1 \\
\hline Vaatplanten & Ruig viooltje & Viola hirta & 23 & 0 & 1 & 0 & -1 \\
\hline Vaatplanten & Driekleurig viooltje & Viola tricolor & 23 & 0 & 1 & 0 & -1 \\
\hline Vaatplanten & Wortelloos kroos & Wolffia arrhiza & 23 & 0 & 1 & 0 & -1 \\
\hline Vaatplanten & Maïs & Zea mays & 23 & 0 & 1 & 0 & -1 \\
\hline Vaatplanten & Witte esdoorn & Acer saccharinum & 22 & 0 & 1 & 1 & -1 \\
\hline Vaatplanten & Gele anemoon & Anemone ranunculoides & 22 & 0 & 1 & 1 & -1 \\
\hline Vaatplanten & Akkerklokje & Campanula rapunculoides & 22 & 0 & 1 & 1 & -1 \\
\hline Vaatplanten & Bittere veldkers & Cardamine amara & 22 & 0 & 1 & 1 & -1 \\
\hline Vaatplanten & Langstekelige distel & Carduus acanthoides & 22 & 0 & 1 & 1 & -1 \\
\hline Vaatplanten & Zeegroene zegge & Carex flacca & 22 & 0 & 1 & 1 & -1 \\
\hline Vaatplanten & Hangende zegge & Carex pendula & 22 & 0 & 1 & 1 & -1 \\
\hline Vaatplanten & Lelietje-van-dalen & Convallaria majalis & 22 & 0 & 1 & 1 & -1 \\
\hline Vaatplanten & Beklierde kogeldistel & Echinops sphaerocephalus & 22 & 0 & 1 & 1 & -1 \\
\hline Vaatplanten & Reuzenpaardenstaart & Equisetum telmateia & 22 & 0 & 1 & 1 & -1 \\
\hline Vaatplanten & Hard zwenkgras & Festuca brevipila & 22 & 0 & 1 & 1 & -1 \\
\hline Vaatplanten & Behaard breukkruid & Herniaria hirsuta & 22 & 0 & 1 & 1 & -1 \\
\hline Vaatplanten & Boshavikskruid & Hieracium sabaudum & 22 & 0 & 1 & 1 & -1 \\
\hline Vaatplanten & Groot springzaad & Impatiens noli-tangere & 22 & 0 & 1 & 1 & -1 \\
\hline Vaatplanten & Vaste lupine & Lupinus polyphyllus & 22 & 0 & 1 & 1 & -1 \\
\hline Vaatplanten & Boksdoorn & Lycium barbarum & 22 & 0 & 1 & 1 & -1 \\
\hline Vaatplanten & Bosgierstgras & Milium effusum & 22 & 0 & 1 & 1 & -1 \\
\hline Vaatplanten & Zompvergeet-mij-nietje & Myosotis laxa subsp. cespitosa & 22 & 0 & 1 & 1 & -1 \\
\hline Vaatplanten & Slanke / Witte waterkers & Nasturtium microphyllum/officinale & 22 & 0 & 1 & 1 & -1 \\
\hline Vaatplanten & Grote keverorchis & Neottia ovata & 22 & 0 & 1 & 1 & -1 \\
\hline Vaatplanten & Slanke mantelanjer & Petrorhagia prolifera & 22 & 0 & 1 & 1 & -1 \\
\hline Vaatplanten & Stijve naaldvaren & Polystichum aculeatum & 22 & 0 & 1 & 1 & -1 \\
\hline Vaatplanten & Kerspruim & Prunus cerasifera & 22 & 0 & 1 & 1 & -1 \\
\hline Vaatplanten & Kruidvlier & Sambucus ebulus & 22 & 0 & 1 & 1 & -1 \\
\hline Vaatplanten & Boskruiskruid & Senecio sylvaticus & 22 & 0 & 1 & 1 & -1 \\
\hline Vaatplanten & Mariadistel & Silybum marianum & 22 & 0 & 1 & 1 & -1 \\
\hline Vaatplanten & Moerasmuur & Stellaria uliginosa & 22 & 0 & 1 & 1 & -1 \\
\hline Vaatplanten & Bleeksporig bosviooltje & Viola riviniana & 22 & 0 & 1 & 1 & -1 \\
\hline Vaatplanten & Kleine steentijm & Clinopodium acinos & 21 & 0 & 1 & 2 & -1 \\
\hline Vaatplanten & Stekelige hanenpoot & Echinochloa muricata & 21 & 0 & 1 & 2 & -1 \\
\hline Vaatplanten & Lidsteng & Hippuris vulgaris & 21 & 0 & 1 & 2 & -1 \\
\hline Vaatplanten & Gele maskerbloem & Mimulus guttatus & 21 & 0 & 1 & 2 & -1 \\
\hline Vaatplanten & Klavervreter & Orobanche minor & 21 & 0 & 1 & 2 & -1 \\
\hline Vaatplanten & Glanzig fonteinkruid & Potamogeton lucens & 21 & 0 & 1 & 2 & -1 \\
\hline Vaatplanten & Noorse ganzerik & Potentilla norvegica & 21 & 0 & 1 & 2 & -1 \\
\hline Vaatplanten & Kruisbes & Ribes uva-crispa & 21 & 0 & 1 & 2 & -1 \\
\hline Vaatplanten & Peterselievlier & Sambucus nigra cv. Laciniata & 21 & 0 & 1 & 2 & -1 \\
\hline Vaatplanten & Hokjespeul & Astragalus glycyphyllos & 20 & 0 & 1 & 3 & -1 \\
\hline
\end{tabular}




\begin{tabular}{|c|c|c|c|c|c|c|c|}
\hline srtgroepen & soort_ned & soort_wet & not & vr & na & $+n$ & a vr-na \\
\hline Vaatplanten & Vingerhelmbloem & Corydalis solida & 20 & 0 & 1 & 3 & -1 \\
\hline Vaatplanten & Kleine ratelaar & Rhinanthus minor & 20 & 0 & 1 & 3 & -1 \\
\hline Vaatplanten & Maretak & Viscum album & 20 & 0 & 1 & 3 & -1 \\
\hline Vaatplanten & Wede & Isatis tinctoria & 19 & 0 & 1 & 4 & -1 \\
\hline Vaatplanten & Avondkoekoeksbloem & Silene latifolia subsp. alba & 18 & 0 & 1 & 5 & -1 \\
\hline Vaatplanten & Duist & Alopecurus myosuroides & 21 & 1 & 2 & 0 & -1 \\
\hline Vaatplanten & Smal tandzaad & Bidens connata & 21 & 1 & 2 & 0 & -1 \\
\hline Vaatplanten & Bernagie & Borago officinalis & 21 & 1 & 2 & 0 & -1 \\
\hline Vaatplanten & Pluimzegge & Carex paniculata & 21 & 1 & 2 & 0 & -1 \\
\hline Vaatplanten & Bleek cypergras & Cyperus eragrostis & 21 & 1 & 2 & 0 & -1 \\
\hline Vaatplanten & Smalle/Brede stekelvaren & Dryopteris carthusiana/dilatata & 21 & 1 & 2 & 0 & -1 \\
\hline Vaatplanten & Dwergkroos & Lemna minuta & 21 & 1 & 2 & 0 & -1 \\
\hline Vaatplanten & Gevlekte rupsklaver & Medicago arabica & 21 & 1 & 2 & 0 & -1 \\
\hline Vaatplanten & Adelaarsvaren & Pteridium aquilinum & 21 & 1 & 2 & 0 & -1 \\
\hline Vaatplanten & Gevlekt longkruid & Pulmonaria officinalis & 21 & 1 & 2 & 0 & -1 \\
\hline Vaatplanten & Veelbloemige roos & Rosa multiflora & 21 & 1 & 2 & 0 & -1 \\
\hline Vaatplanten & Donkere vetmuur & Sagina apetala & 21 & 1 & 2 & 0 & -1 \\
\hline Vaatplanten & Geoorde wilg & Salix aurita & 21 & 1 & 2 & 0 & -1 \\
\hline Vaatplanten & Moerasandijvie & Tephroseris palustris & 21 & 1 & 2 & 0 & -1 \\
\hline Vaatplanten & Zomerlinde & Tilia platyphyllos & 21 & 1 & 2 & 0 & -1 \\
\hline Vaatplanten & Witte paardenkastanje & Aesculus hippocastanum & 20 & 1 & 2 & 1 & -1 \\
\hline Vaatplanten & Mahonie & Berberis aquifolium & 20 & 1 & 2 & 1 & -1 \\
\hline Vaatplanten & Zandzegge & Carex arenaria & 20 & 1 & 2 & 1 & -1 \\
\hline Vaatplanten & Beemdooievaarsbek & Geranium pratense & 20 & 1 & 2 & 1 & -1 \\
\hline Vaatplanten & Boslathyrus & Lathyrus sylvestris & 20 & 1 & 2 & 1 & -1 \\
\hline Vaatplanten & Drijvend fonteinkruid & Potamogeton natans & 20 & 1 & 2 & 1 & -1 \\
\hline Vaatplanten & Stekend loogkruid & Salsola kali & 20 & 1 & 2 & 1 & -1 \\
\hline Vaatplanten & Gewone spurrie & Spergula arvensis & 20 & 1 & 2 & 1 & -1 \\
\hline Vaatplanten & Smalle waterweegbree & Alisma gramineum & 19 & 1 & 2 & 2 & -1 \\
\hline Vaatplanten & Asperge & Asparagus officinalis subsp. officinalis & 19 & 1 & 2 & 2 & -1 \\
\hline Vaatplanten & Knolribzaad & Chaerophyllum bulbosum & 19 & 1 & 2 & 2 & -1 \\
\hline Vaatplanten & Veldgerst & Hordeum secalinum & 19 & 1 & 2 & 2 & -1 \\
\hline Vaatplanten & Klein springzaad & Impatiens parviflora & 19 & 1 & 2 & 2 & -1 \\
\hline Vaatplanten & Bosvergeet-mij-nietje & Myosotis sylvatica & 19 & 1 & 2 & 2 & -1 \\
\hline Vaatplanten & Karwijvarkenskervel & Peucedanum carvifolia & 19 & 1 & 2 & 2 & -1 \\
\hline Vaatplanten & Gewone salomonszegel & Polygonatum multiflorum & 19 & 1 & 2 & 2 & -1 \\
\hline Vaatplanten & Bonte wikke & Vicia villosa & 19 & 1 & 2 & 2 & -1 \\
\hline Vaatplanten & Stijf barbarakruid & Barbarea stricta & 18 & 1 & 2 & 3 & -1 \\
\hline Vaatplanten & Liggende ganzenvoet & Chenopodium pumilio & 18 & 1 & 2 & 3 & -1 \\
\hline Vaatplanten & Hopwarkruid & Cuscuta lupuliformis & 17 & 1 & 2 & 4 & -1 \\
\hline Vaatplanten & Oostenrijkse kers & Rorippa austriaca & 17 & 1 & 2 & 4 & -1 \\
\hline Vaatplanten & Witte munt & Mentha suaveolens & 16 & 1 & 2 & 5 & -1 \\
\hline Vaatplanten & Stinkende ballote & Ballota nigra subsp. meridionalis & 13 & 1 & 2 & 8 & -1 \\
\hline Vaatplanten & Kromhals & Anchusa arvensis & 19 & 2 & 3 & 0 & -1 \\
\hline Vaatplanten & Brem & Cytisus scoparius & 19 & 2 & 3 & 0 & -1 \\
\hline Vaatplanten & Gladde witbol & Holcus mollis & 19 & 2 & 3 & 0 & -1 \\
\hline Vaatplanten & Vlas & Linum usitatissimum & 19 & 2 & 3 & 0 & -1 \\
\hline Vaatplanten & Slaapbol & Papaver somniferum & 19 & 2 & 3 & 0 & -1 \\
\hline Vaatplanten & Peer & Pyrus communis & 19 & 2 & 3 & 0 & -1 \\
\hline Vaatplanten & Slanke waterweegbree & Alisma lanceolatum & 18 & 2 & 3 & 1 & -1 \\
\hline Vaatplanten & Raapzaad & Brassica rapa & 18 & 2 & 3 & 1 & -1 \\
\hline Vaatplanten & Korenbloem & Centaurea cyanus & 18 & 2 & 3 & 1 & -1 \\
\hline Vaatplanten & Appel & Malus sylvestris & 18 & 2 & 3 & 1 & -1 \\
\hline Vaatplanten & Grauwe abeel & Populus $x$ canescens & 18 & 2 & 3 & 1 & -1 \\
\hline Vaatplanten & Vierzadige wikke & Vicia tetrasperma subsp. tetrasperma & 18 & 2 & 3 & 1 & -1 \\
\hline Vaatplanten & Puntkroos & Lemna trisulca & 17 & 2 & 3 & 2 & -1 \\
\hline Vaatplanten & Witte waterlelie & Nymphaea alba & 17 & 2 & 3 & 2 & -1 \\
\hline Vaatplanten & Canadese guldenroede & Solidago canadensis & 17 & 2 & 3 & 2 & -1 \\
\hline Vaatplanten & Aardaker & Lathyrus tuberosus & 16 & 2 & 3 & 3 & -1 \\
\hline Vaatplanten & Harige ratelaar & Rhinanthus alectorolophus & 16 & 2 & 3 & 3 & -1 \\
\hline Vaatplanten & Dolle kervel & Chaerophyllum temulum & 15 & 2 & 3 & 4 & -1 \\
\hline Vaatplanten & Beemdlangbloem & Festuca pratensis & 15 & 2 & 3 & 4 & -1 \\
\hline Vaatplanten & Geoorde zuring & Rumex thyrsiflorus & 15 & 2 & 3 & 4 & -1 \\
\hline Vaatplanten & Liesgras & Glyceria maxima & 10 & 2 & 3 & 9 & -1 \\
\hline
\end{tabular}




\begin{tabular}{|c|c|c|c|c|c|c|c|}
\hline srtgroepen & soort_ned & soort_wet & not & vr & na & $r+n$ & a vr-na \\
\hline Vaatplanten & Gewone raket & Sisymbrium officinale & 8 & 2 & 3 & 11 & -1 \\
\hline Vaatplanten & Vingerhoedskruid & Digitalis purpurea & 17 & 3 & 4 & 0 & -1 \\
\hline Vaatplanten & Ruwe smele & Deschampsia cespitosa & 15 & 3 & 4 & 2 & -1 \\
\hline Vaatplanten & Gladde iep & Ulmus minor & 14 & 3 & 4 & 3 & -1 \\
\hline Vaatplanten & Grote lisdodde & Typha latifolia & 11 & 3 & 4 & 6 & -1 \\
\hline Vaatplanten & Ruige zegge & Carex hirta & 7 & 3 & 4 & 10 & -1 \\
\hline Vaatplanten & Heermoes & Equisetum arvense & 4 & 3 & 4 & 13 & -1 \\
\hline Vaatplanten & Engels raaigras & Lolium perenne & 4 & 3 & 4 & 13 & -1 \\
\hline Vaatplanten & Blaassilene & Silene vulgaris & 15 & 4 & 5 & 0 & -1 \\
\hline Vaatplanten & Moeraszegge & Carex acutiformis & 14 & 4 & 5 & 1 & -1 \\
\hline Vaatplanten & Amerikaanse vogelkers & Prunus serotina & 14 & 4 & 5 & 1 & -1 \\
\hline Vaatplanten & Geknikte vossenstaart & Alopecurus geniculatus & 12 & 4 & 5 & 3 & -1 \\
\hline Vaatplanten & Doornappel & Datura stramonium & 11 & 4 & 5 & 4 & -1 \\
\hline Vaatplanten & Pastinaak & Pastinaca sativa subsp. sativa & 10 & 4 & 5 & 5 & -1 \\
\hline Vaatplanten & Zacht vetkruid & Sedum sexangulare & 8 & 4 & 5 & 7 & -1 \\
\hline Vaatplanten & Kattendoorn & Ononis repens subsp. spinosa & 7 & 4 & 5 & 8 & -1 \\
\hline Vaatplanten & Gewone hoornbloem & Cerastium fontanum subsp. vulgare & 5 & 4 & 5 & 10 & -1 \\
\hline Vaatplanten & Witte klaver & Trifolium repens & 2 & 4 & 5 & 13 & -1 \\
\hline Vaatplanten & Mannagras & Glyceria fluitans & 12 & 5 & 6 & 1 & -1 \\
\hline Vaatplanten & Groot kaasjeskruid & Malva sylvestris & 10 & 5 & 6 & 3 & -1 \\
\hline Vaatplanten & Groot warkruid & Cuscuta europaea & 5 & 5 & 6 & 8 & -1 \\
\hline Vaatplanten & Veldbeemdgras & Poa pratensis & 7 & 6 & 7 & 4 & -1 \\
\hline Vaatplanten & Zachte dravik & Bromus hordeaceus subsp. hordeaceus & 6 & 6 & 7 & 5 & -1 \\
\hline Vaatplanten & Kleine klaver & Trifolium dubium & 5 & 7 & 8 & 4 & -1 \\
\hline Vaatplanten & Moerasstruisgras & Agrostis canina & 22 & 0 & 2 & 0 & -2 \\
\hline Vaatplanten & Oosterse anemoon & Anemone blanda & 22 & 0 & 2 & 0 & -2 \\
\hline Vaatplanten & Zwenkdravik & Anisantha tectorum & 22 & 0 & 2 & 0 & -2 \\
\hline Vaatplanten & Grote leeuwenbek & Antirrhinum majus & 22 & 0 & 2 & 0 & -2 \\
\hline Vaatplanten & Nieuw-Nederlandse aster & Aster novi-belgii & 22 & 0 & 2 & 0 & -2 \\
\hline Vaatplanten & Bergdravik & Bromopsis erecta & 22 & 0 & 2 & 0 & -2 \\
\hline Vaatplanten & Ruige fijnstraal & Conyza bilbaoana & 22 & 0 & 2 & 0 & -2 \\
\hline Vaatplanten & Paardenbloemstreepzaad & Crepis vesicaria subsp. taraxacifolia & 22 & 0 & 2 & 0 & -2 \\
\hline Vaatplanten & Bergbasterdwederik & Epilobium montanum & 22 & 0 & 2 & 0 & -2 \\
\hline Vaatplanten & Muurfijnstraal & Erigeron karvinskianus & 22 & 0 & 2 & 0 & -2 \\
\hline Vaatplanten & Kleine wolfsmelk & Euphorbia exigua & 22 & 0 & 2 & 0 & -2 \\
\hline Vaatplanten & Weidegeelster & Gagea pratensis & 22 & 0 & 2 & 0 & -2 \\
\hline Vaatplanten & Akkergeelster & Gagea villosa & 22 & 0 & 2 & 0 & -2 \\
\hline Vaatplanten & Lievevrouwebedstro & Galium odoratum & 22 & 0 & 2 & 0 & -2 \\
\hline Vaatplanten & Stijve zonnebloem & Helianthus $x$ laetiflorus & 22 & 0 & 2 & 0 & -2 \\
\hline Vaatplanten & Dicht havikskruid s.l. & Hieracium vulgatum & 22 & 0 & 2 & 0 & -2 \\
\hline Vaatplanten & Grijze mosterd & Hirschfeldia incana & 22 & 0 & 2 & 0 & -2 \\
\hline Vaatplanten & Bultkroos & Lemna gibba & 22 & 0 & 2 & 0 & -2 \\
\hline Vaatplanten & Haagliguster & Ligustrum ovalifolium & 22 & 0 & 2 & 0 & -2 \\
\hline Vaatplanten & Smalle rolklaver & Lotus glaber & 22 & 0 & 2 & 0 & -2 \\
\hline Vaatplanten & Waterpostelein & Lythrum portula & 22 & 0 & 2 & 0 & -2 \\
\hline Vaatplanten & Schijnpapaver & Meconopsis cambrica & 22 & 0 & 2 & 0 & -2 \\
\hline Vaatplanten & Citroenmelisse & Melissa officinalis & 22 & 0 & 2 & 0 & -2 \\
\hline Vaatplanten & Akkerleeuwenbek & Misopates orontium & 22 & 0 & 2 & 0 & -2 \\
\hline Vaatplanten & Muursla & Mycelis muralis & 22 & 0 & 2 & 0 & -2 \\
\hline Vaatplanten & Groot nimfkruid & Najas marina & 22 & 0 & 2 & 0 & -2 \\
\hline Vaatplanten & Trompetnarcis & Narcissus pseudonarcissus subsp. major & 22 & 0 & 2 & 0 & -2 \\
\hline Vaatplanten & Pijptorkruid & Oenanthe fistulosa & 22 & 0 & 2 & 0 & -2 \\
\hline Vaatplanten & Oenothera & Oenothera ersteinensis & 22 & 0 & 2 & 0 & -2 \\
\hline Vaatplanten & Draadgierst & Panicum capillare & 22 & 0 & 2 & 0 & -2 \\
\hline Vaatplanten & Kleine duizendknoop & Persicaria minor & 22 & 0 & 2 & 0 & -2 \\
\hline Vaatplanten & Fijnspar & Picea abies & 22 & 0 & 2 & 0 & -2 \\
\hline Vaatplanten & Gekroesd $\mathrm{x}$ puntig fonteinkruid & Potamogeton $\mathrm{x}$ lintonii & 22 & 0 & 2 & 0 & -2 \\
\hline Vaatplanten & Voorjaarsganzerik & Potentilla tabernaemontani & 22 & 0 & 2 & 0 & -2 \\
\hline Vaatplanten & Hazelaarbraam & Rubus corylifolius & 22 & 0 & 2 & 0 & -2 \\
\hline Vaatplanten & Ruwe bies & Schoenoplectus tabernaemontani & 22 & 0 & 2 & 0 & -2 \\
\hline Vaatplanten & Franse silene & Silene gallica & 22 & 0 & 2 & 0 & -2 \\
\hline Vaatplanten & Inkarnaatklaver & Trifolium incarnatum & 22 & 0 & 2 & 0 & -2 \\
\hline Vaatplanten & Groot blaasjeskruid & Utricularia vulgaris & 22 & 0 & 2 & 0 & -2 \\
\hline Vaatplanten & Gegroefde veldsla & Valerianella carinata & 22 & 0 & 2 & 0 & -2 \\
\hline
\end{tabular}




\begin{tabular}{|c|c|c|c|c|c|c|c|}
\hline srtgroepen & soort_ned & soort_wet & not & vr & na & $r+n t$ & a vr-na \\
\hline Vaatplanten & Blauwe $\times$ Rode waterereprijs & Veronica $\mathrm{x}$ lackschewitzii & 22 & 0 & 2 & 0 & -2 \\
\hline Vaatplanten & Witte amarant & Amaranthus albus & 21 & 0 & 2 & 1 & -2 \\
\hline Vaatplanten & Amerikaans krentenboompje & Amelanchier lamarckii & 21 & 0 & 2 & 1 & -2 \\
\hline Vaatplanten & Bosanemoon & Anemone nemorosa & 21 & 0 & 2 & 1 & -2 \\
\hline Vaatplanten & Kleine leeuwenklauw & Aphanes australis & 21 & 0 & 2 & 1 & -2 \\
\hline Vaatplanten & Groot moerasscherm & Apium nodiflorum & 21 & 0 & 2 & 1 & -2 \\
\hline Vaatplanten & Donzige klit & Arctium tomentosum & 21 & 0 & 2 & 1 & -2 \\
\hline Vaatplanten & Pijpbloem & Aristolochia clematitis & 21 & 0 & 2 & 1 & -2 \\
\hline Vaatplanten & Wijfjesvaren & Athyrium filix-femina & 21 & 0 & 2 & 1 & -2 \\
\hline Vaatplanten & Winterpostelein & Claytonia perfoliata & 21 & 0 & 2 & 1 & -2 \\
\hline Vaatplanten & Grove varkenskers & Coronopus squamatus & 21 & 0 & 2 & 1 & -2 \\
\hline Vaatplanten & Riempjes & Corrigiola litoralis & 21 & 0 & 2 & 1 & -2 \\
\hline Vaatplanten & Waterviolier & Hottonia palustris & 21 & 0 & 2 & 1 & -2 \\
\hline Vaatplanten & Gele dovenetel & Lamiastrum galeobdolon subsp. galeobdolon & 21 & 0 & 2 & 1 & -2 \\
\hline Vaatplanten & Behaarde boterbloem & Ranunculus sardous & 21 & 0 & 2 & 1 & -2 \\
\hline Vaatplanten & Krabbenscheer & Stratiotes aloides & 21 & 0 & 2 & 1 & -2 \\
\hline Vaatplanten & Welriekende agrimonie & Agrimonia procera & 20 & 0 & 2 & 2 & -2 \\
\hline Vaatplanten & Borstelkrans & Clinopodium vulgare & 20 & 0 & 2 & 2 & -2 \\
\hline Vaatplanten & Schaafstro & Equisetum hyemale & 20 & 0 & 2 & 2 & -2 \\
\hline Vaatplanten & Kantig hertshooi & Hypericum maculatum subsp. obtusiusculum & 20 & 0 & 2 & 2 & -2 \\
\hline Vaatplanten & Oranje springzaad & Impatiens capensis & 20 & 0 & 2 & 2 & -2 \\
\hline Vaatplanten & Grove den & Pinus sylvestris & 20 & 0 & 2 & 2 & -2 \\
\hline Vaatplanten & Wegedoorn & Rhamnus cathartica & 20 & 0 & 2 & 2 & -2 \\
\hline Vaatplanten & Wilgzuring & Rumex salicifolius & 20 & 0 & 2 & 2 & -2 \\
\hline Vaatplanten & Duinvogelmuur & Stellaria pallida & 20 & 0 & 2 & 2 & -2 \\
\hline Vaatplanten & Viltig kruiskruid & Jacobaea erucifolia & 19 & 0 & 2 & 3 & -2 \\
\hline Vaatplanten & Hertsmunt & Mentha longifolia & 18 & 0 & 2 & 4 & -2 \\
\hline Vaatplanten & Goudbes & Physalis peruviana & 18 & 0 & 2 & 4 & -2 \\
\hline Vaatplanten & Kleine kaardebol & Dipsacus pilosus & 16 & 0 & 2 & 6 & -2 \\
\hline Vaatplanten & Tengere zandmuur & Arenaria leptoclados & 20 & 1 & 3 & 0 & -2 \\
\hline Vaatplanten & Bitter barbarakruid & Barbarea intermedia & 20 & 1 & 3 & 0 & -2 \\
\hline Vaatplanten & Oeverzegge & Carex riparia & 20 & 1 & 3 & 0 & -2 \\
\hline Vaatplanten & Kamferalant & Dittrichia graveolens & 20 & 1 & 3 & 0 & -2 \\
\hline Vaatplanten & Smalle stekelvaren & Dryopteris carthusiana & 20 & 1 & 3 & 0 & -2 \\
\hline Vaatplanten & Straatwolfsmelk & Euphorbia maculata & 20 & 1 & 3 & 0 & -2 \\
\hline Vaatplanten & Bastaardduizendknoop & Fallopia $\mathrm{x}$ bohemica & 20 & 1 & 3 & 0 & -2 \\
\hline Vaatplanten & Wilde liguster & Ligustrum vulgare & 20 & 1 & 3 & 0 & -2 \\
\hline Vaatplanten & Gewone/Brede eikvaren & Polypodium vulgare/interjectum & 20 & 1 & 3 & 0 & -2 \\
\hline Vaatplanten & Viltganzerik & Potentilla argentea & 20 & 1 & 3 & 0 & -2 \\
\hline Vaatplanten & Zwarte bes & Ribes nigrum & 20 & 1 & 3 & 0 & -2 \\
\hline Vaatplanten & Absintalsem & Artemisia absinthium & 19 & 1 & 3 & 1 & -2 \\
\hline Vaatplanten & Boskortsteel & Brachypodium sylvaticum & 19 & 1 & 3 & 1 & -2 \\
\hline Vaatplanten & Ruig klokje & Campanula trachelium & 19 & 1 & 3 & 1 & -2 \\
\hline Vaatplanten & Hoge cyperzegge & Carex pseudocyperus & 19 & 1 & 3 & 1 & -2 \\
\hline Vaatplanten & Gevlekte scheerling & Conium maculatum & 19 & 1 & 3 & 1 & -2 \\
\hline Vaatplanten & Grote zandkool & Diplotaxis tenuifolia & 19 & 1 & 3 & 1 & -2 \\
\hline Vaatplanten & Kikkerbeet & Hydrocharis morsus-ranae & 19 & 1 & 3 & 1 & -2 \\
\hline Vaatplanten & Frans hertshooi & Hypericum $x$ desetangsii & 19 & 1 & 3 & 1 & -2 \\
\hline Vaatplanten & Overblijvende ossentong & Pentaglottis sempervirens & 19 & 1 & 3 & 1 & -2 \\
\hline Vaatplanten & Doorgroeid fonteinkruid & Potamogeton perfoliatus & 19 & 1 & 3 & 1 & -2 \\
\hline Vaatplanten & Ruwe iep & Ulmus glabra & 19 & 1 & 3 & 1 & -2 \\
\hline Vaatplanten & Franse/Basterdamarant & Amaranthus hybridus & 18 & 1 & 3 & 2 & -2 \\
\hline Vaatplanten & Cipreswolfsmelk & Euphorbia cyparissias & 18 & 1 & 3 & 2 & -2 \\
\hline Vaatplanten & Witte waterkers & Nasturtium officinale & 18 & 1 & 3 & 2 & -2 \\
\hline Vaatplanten & Beuk & Fagus sylvatica & 17 & 1 & 3 & 3 & -2 \\
\hline Vaatplanten & Kruisdistel & Eryngium campestre & 8 & 1 & 3 & 12 & -2 \\
\hline Vaatplanten & Veldrus & Juncus acutiflorus & 18 & 2 & 4 & 0 & -2 \\
\hline Vaatplanten & Grote ratelaar & Rhinanthus angustifolius & 17 & 2 & 4 & 1 & -2 \\
\hline Vaatplanten & Gewone veldbies & Luzula campestris & 16 & 2 & 4 & 2 & -2 \\
\hline Vaatplanten & Kraakwilg & Salix fragilis & 16 & 2 & 4 & 2 & -2 \\
\hline Vaatplanten & Kleine majer & Amaranthus blitum & 15 & 2 & 4 & 3 & -2 \\
\hline Vaatplanten & Kleine watereppe & Berula erecta & 15 & 2 & 4 & 3 & -2 \\
\hline Vaatplanten & Mannetjesvaren & Dryopteris filix-mas & 15 & 2 & 4 & 3 & -2 \\
\hline Vaatplanten & Aardpeer & Helianthus tuberosus & 15 & 2 & 4 & 3 & -2 \\
\hline
\end{tabular}




\begin{tabular}{|c|c|c|c|c|c|c|c|}
\hline srtgroepen & soort_ned & soort_wet & not & vr & na & $r+n$ & a vr-na \\
\hline Vaatplanten & Luzerne & Medicago sativa & 15 & 2 & 4 & 3 & -2 \\
\hline Vaatplanten & Zeegroene ganzenvoet & Chenopodium glaucum & 14 & 2 & 4 & 4 & -2 \\
\hline Vaatplanten & Pijlkruid & Sagittaria sagittifolia & 14 & 2 & 4 & 4 & -2 \\
\hline Vaatplanten & Maarts viooltje & Viola odorata & 14 & 2 & 4 & 4 & -2 \\
\hline Vaatplanten & Grof hoornblad & Ceratophyllum demersum & 12 & 2 & 4 & 6 & -2 \\
\hline Vaatplanten & Akkerkool & Lapsana communis & 12 & 2 & 4 & 6 & -2 \\
\hline Vaatplanten & Kropaar & Dactylis glomerata & 3 & 2 & 4 & 15 & -2 \\
\hline Vaatplanten & Koolzaad & Brassica napus & 15 & 3 & 5 & 1 & -2 \\
\hline Vaatplanten & IJle zegge & Carex remota & 14 & 3 & 5 & 2 & -2 \\
\hline Vaatplanten & Zevenblad & Aegopodium podagraria & 13 & 3 & 5 & 3 & -2 \\
\hline Vaatplanten & Watertorkruid & Oenanthe aquatica & 13 & 3 & 5 & 3 & -2 \\
\hline Vaatplanten & Zwarte mosterd & Brassica nigra & 9 & 3 & 5 & 7 & -2 \\
\hline Vaatplanten & Knopig helmkruid & Scrophularia nodosa & 9 & 3 & 5 & 7 & -2 \\
\hline Vaatplanten & Grote vossenstaart & Alopecurus pratensis & 8 & 3 & 5 & 8 & -2 \\
\hline Vaatplanten & Veldlathyrus & Lathyrus pratensis & 7 & 3 & 5 & 9 & -2 \\
\hline Vaatplanten & Sint-Janskruid & Hypericum perforatum & 6 & 3 & 5 & 10 & -2 \\
\hline Vaatplanten & Gewone agrimonie & Agrimonia eupatoria & 5 & 3 & 5 & 11 & -2 \\
\hline Vaatplanten & Fluitenkruid & Anthriscus sylvestris & 4 & 3 & 5 & 12 & -2 \\
\hline Vaatplanten & Herderstasje & Capsella bursa-pastoris & 4 & 3 & 5 & 12 & -2 \\
\hline Vaatplanten & Gewone rolklaver & Lotus corniculatus & 4 & 3 & 5 & 12 & -2 \\
\hline Vaatplanten & Veenwortel & Persicaria amphibia & 4 & 3 & 5 & 12 & -2 \\
\hline Vaatplanten & Hondsdraf & Glechoma hederacea & 3 & 3 & 5 & 13 & -2 \\
\hline Vaatplanten & Tweerijige zegge & Carex disticha & 13 & 4 & 6 & 1 & -2 \\
\hline Vaatplanten & Brede wespenorchis & Epipactis helleborine & 9 & 4 & 6 & 5 & -2 \\
\hline Vaatplanten & Look-zonder-look & Alliaria petiolata & 7 & 4 & 6 & 7 & -2 \\
\hline Vaatplanten & Bitterzoet & Solanum dulcamara & 6 & 4 & 6 & 8 & -2 \\
\hline Vaatplanten & Gestreepte witbol & Holcus lanatus & 5 & 4 & 6 & 9 & -2 \\
\hline Vaatplanten & Gewone smeerwortel & Symphytum officinale & 3 & 4 & 6 & 11 & -2 \\
\hline Vaatplanten & Scherpe zegge & Carex acuta & 6 & 5 & 7 & 6 & -2 \\
\hline Vaatplanten & Scherpe boterbloem & Ranunculus acris & 4 & 5 & 7 & 8 & -2 \\
\hline Vaatplanten & Glanshaver & Arrhenatherum elatius & 1 & 5 & 7 & 11 & -2 \\
\hline Vaatplanten & Stokroos & Alcea rosea & 21 & 0 & 3 & 0 & -3 \\
\hline Vaatplanten & Witte els & Alnus incana & 21 & 0 & 3 & 0 & -3 \\
\hline Vaatplanten & Grote leeuwenklauw & Aphanes arvensis & 21 & 0 & 3 & 0 & -3 \\
\hline Vaatplanten & Goudsbloem & Calendula officinalis & 21 & 0 & 3 & 0 & -3 \\
\hline Vaatplanten & Eenbloemige veldkers & Cardamine corymbosa & 21 & 0 & 3 & 0 & -3 \\
\hline Vaatplanten & Driedistel & Carlina vulgaris & 21 & 0 & 3 & 0 & -3 \\
\hline Vaatplanten & Deens lepelblad & Cochlearia danica & 21 & 0 & 3 & 0 & -3 \\
\hline Vaatplanten & Valse ridderspoor & Consolida ajacis & 21 & 0 & 3 & 0 & -3 \\
\hline Vaatplanten & Gevlamde fijnstraal & Conyza bonariensis & 21 & 0 & 3 & 0 & -3 \\
\hline Vaatplanten & Veldwarkruid & Cuscuta campestris & 21 & 0 & 3 & 0 & -3 \\
\hline Vaatplanten & Dwergviltkruid & Filago minima & 21 & 0 & 3 & 0 & -3 \\
\hline Vaatplanten & Venkel & Foeniculum vulgare & 21 & 0 & 3 & 0 & -3 \\
\hline Vaatplanten & Gele ganzenbloem & Glebionis segetum & 21 & 0 & 3 & 0 & -3 \\
\hline Vaatplanten & Grijs havikskruid & Hieracium praealtum & 21 & 0 & 3 & 0 & -3 \\
\hline Vaatplanten & Steenkruidkers & Lepidium ruderale & 21 & 0 & 3 & 0 & -3 \\
\hline Vaatplanten & Tuinjudaspenning & Lunaria annua & 21 & 0 & 3 & 0 & -3 \\
\hline Vaatplanten & Zomp-/Moerasvergeet-mij-nietje & Myosotis laxa/scorpioides & 21 & 0 & 3 & 0 & -3 \\
\hline Vaatplanten & Kogelbies & Scirpoides holoschoenus & 21 & 0 & 3 & 0 & -3 \\
\hline Vaatplanten & Basterdamarant & Amaranthus hybridus s.s. & 20 & 0 & 3 & 1 & -3 \\
\hline Vaatplanten & Grote windhalm & Apera spica-venti & 20 & 0 & 3 & 1 & -3 \\
\hline Vaatplanten & Canadese kornoelje & Cornus sericea & 20 & 0 & 3 & 1 & -3 \\
\hline Vaatplanten & Ruige rupsklaver & Medicago polymorpha & 20 & 0 & 3 & 1 & -3 \\
\hline Vaatplanten & Bonte luzerne & Medicago $\mathrm{x}$ varia & 20 & 0 & 3 & 1 & -3 \\
\hline Vaatplanten & Zittende zannichellia & Zannichellia palustris subsp. palustris & 20 & 0 & 3 & 1 & -3 \\
\hline Vaatplanten & Klein vogelpootje & Ornithopus perpusillus & 19 & 0 & 3 & 2 & -3 \\
\hline Vaatplanten & Roze vetkruid & Sedum spurium & 19 & 0 & 3 & 2 & -3 \\
\hline Vaatplanten & Groot akkerscherm & Ammi majus & 18 & 0 & 3 & 3 & -3 \\
\hline Vaatplanten & Hondstarwegras & Elymus caninus & 18 & 0 & 3 & 3 & -3 \\
\hline Vaatplanten & Damastbloem & Hesperis matronalis & 18 & 0 & 3 & 3 & -3 \\
\hline Vaatplanten & Plataan & Platanus hispanica & 17 & 0 & 3 & 4 & -3 \\
\hline Vaatplanten & Gevlekte dovenetel & Lamium maculatum s.s. & 16 & 0 & 3 & 5 & -3 \\
\hline Vaatplanten & Hazelaar & Corylus avellana & 14 & 0 & 3 & 7 & -3 \\
\hline Vaatplanten & Bolboschoenus & Bolboschoenus laticarpus & 19 & 1 & 4 & 0 & -3 \\
\hline
\end{tabular}




\begin{tabular}{|c|c|c|c|c|c|c|c|}
\hline srtgroepen & soort_ned & soort_wet & not & & na & $+n t$ & vr-na \\
\hline Vaatplanten & Egelboterbloem & Ranunculus flammula & 19 & 1 & 4 & 0 & -3 \\
\hline Vaatplanten & Lange ereprijs & Veronica longifolia & 19 & 1 & 4 & 0 & -3 \\
\hline Vaatplanten & Hemelboom & Ailanthus altissima & 18 & 1 & 4 & 1 & -3 \\
\hline Vaatplanten & Bosaardbei & Fragaria vesca & 18 & 1 & 4 & 1 & -3 \\
\hline Vaatplanten & Kleine pimpernel & Sanguisorba minor subsp. minor & 18 & 1 & 4 & 1 & -3 \\
\hline Vaatplanten & Witte krodde & Thlaspi arvense & 18 & 1 & 4 & 1 & -3 \\
\hline Vaatplanten & Kale jonker & Cirsium palustre & 17 & 1 & 4 & 2 & -3 \\
\hline Vaatplanten & Holpijp & Equisetum fluviatile & 17 & 1 & 4 & 2 & -3 \\
\hline Vaatplanten & Straatliefdegras & Eragrostis pilosa & 17 & 1 & 4 & 2 & -3 \\
\hline Vaatplanten & Heggenduizendknoop & Fallopia dumetorum & 17 & 1 & 4 & 2 & -3 \\
\hline Vaatplanten & Fijne waterranonkel & Ranunculus aquatilis & 17 & 1 & 4 & 2 & -3 \\
\hline Vaatplanten & Kleine lisdodde & Typha angustifolia & 17 & 1 & 4 & 2 & -3 \\
\hline Vaatplanten & Noorse esdoorn & Acer platanoides & 16 & 1 & 4 & 3 & -3 \\
\hline Vaatplanten & Beklierde nachtschade & Solanum nigrum subsp. schultesii & 16 & 1 & 4 & 3 & -3 \\
\hline Vaatplanten & Haagbeuk & Carpinus betulus & 15 & 1 & 4 & 4 & -3 \\
\hline Vaatplanten & Handjesgras & Cynodon dactylon & 15 & 1 & 4 & 4 & -3 \\
\hline Vaatplanten & Tomaat & Solanum lycopersicum & 15 & 1 & 4 & 4 & -3 \\
\hline Vaatplanten & Kleine varkenskers & Coronopus didymus & 14 & 1 & 4 & 5 & -3 \\
\hline Vaatplanten & Japanse duizendknoop & Fallopia japonica & 14 & 1 & 4 & 5 & -3 \\
\hline Vaatplanten & Akkerhoornbloem & Cerastium arvense & 12 & 1 & 4 & 7 & -3 \\
\hline Vaatplanten & Gele morgenster & Tragopogon pratensis subsp. pratensis & 12 & 1 & 4 & 7 & -3 \\
\hline Vaatplanten & Grote kattenstaart & Lythrum salicaria & 1 & 1 & 4 & 18 & -3 \\
\hline Vaatplanten & Ratelpopulier & Populus tremula & 17 & 2 & 5 & 0 & -3 \\
\hline Vaatplanten & Gladde ereprijs & Veronica polita & 17 & 2 & 5 & 0 & -3 \\
\hline Vaatplanten & Slangenkruid & Echium vulgare & 16 & 2 & 5 & 1 & -3 \\
\hline Vaatplanten & Knopherik & Raphanus raphanistrum & 16 & 2 & 5 & 1 & -3 \\
\hline Vaatplanten & Akkerviooltje & Viola arvensis & 15 & 2 & 5 & 2 & -3 \\
\hline Vaatplanten & Mierikswortel & Armoracia rusticana & 14 & 2 & 5 & 3 & -3 \\
\hline Vaatplanten & Tenger fonteinkruid & Potamogeton pusillus & 14 & 2 & 5 & 3 & -3 \\
\hline Vaatplanten & Rijstgras & Leersia oryzoides & 13 & 2 & 5 & 4 & -3 \\
\hline Vaatplanten & Kamgras & Cynosurus cristatus & 12 & 2 & 5 & 5 & -3 \\
\hline Vaatplanten & Robertskruid & Geranium robertianum & 12 & 2 & 5 & 5 & -3 \\
\hline Vaatplanten & Echt bitterkruid & Picris hieracioides & 12 & 2 & 5 & 5 & -3 \\
\hline Vaatplanten & Klein vlooienkruid & Pulicaria vulgaris & 12 & 2 & 5 & 5 & -3 \\
\hline Vaatplanten & Gewoon barbarakruid & Barbarea vulgaris & 11 & 2 & 5 & 6 & -3 \\
\hline Vaatplanten & Heggenwikke & Vicia sepium & 11 & 2 & 5 & 6 & -3 \\
\hline Vaatplanten & Rapunzelklokje & Campanula rapunculus & 9 & 2 & 5 & 8 & -3 \\
\hline Vaatplanten & Rietzwenkgras & Festuca arundinacea & 9 & 2 & 5 & 8 & -3 \\
\hline Vaatplanten & Gewone vlier & Sambucus nigra & 7 & 2 & 5 & 10 & -3 \\
\hline Vaatplanten & Gewone berenklauw & Heracleum sphondylium & 3 & 2 & 5 & 14 & -3 \\
\hline Vaatplanten & Zandhoornbloem & Cerastium semidecandrum & 15 & 3 & 6 & 0 & -3 \\
\hline Vaatplanten & Veelwortelig kroos & Spirodela polyrhiza & 14 & 3 & 6 & 1 & -3 \\
\hline Vaatplanten & Hoenderbeet & Lamium amplexicaule & 13 & 3 & 6 & 2 & -3 \\
\hline Vaatplanten & Kleine leeuwentand & Leontodon saxatilis & 13 & 3 & 6 & 2 & -3 \\
\hline Vaatplanten & Mattenbies & Schoenoplectus lacustris & 13 & 3 & 6 & 2 & -3 \\
\hline Vaatplanten & Zoete kers & Prunus avium & 11 & 3 & 6 & 4 & -3 \\
\hline Vaatplanten & Akkermunt & Mentha arvensis & 10 & 3 & 6 & 5 & -3 \\
\hline Vaatplanten & Ringelwikke & Vicia hirsuta & 10 & 3 & 6 & 5 & -3 \\
\hline Vaatplanten & Herik & Sinapis arvensis & 8 & 3 & 6 & 7 & -3 \\
\hline Vaatplanten & Akkerkers & Rorippa sylvestris & 6 & 3 & 6 & 9 & -3 \\
\hline Vaatplanten & Schietwilg & Salix alba & 6 & 3 & 6 & 9 & -3 \\
\hline Vaatplanten & Gewoon varkensgras & Polygonum aviculare & 5 & 3 & 6 & 10 & -3 \\
\hline Vaatplanten & Ridderzuring & Rumex obtusifolius & 3 & 3 & 6 & 12 & -3 \\
\hline Vaatplanten & Heksenmelk & Euphorbia esula & 2 & 3 & 6 & 13 & -3 \\
\hline Vaatplanten & Boerenwormkruid & Tanacetum vulgare & 1 & 3 & 6 & 14 & -3 \\
\hline Vaatplanten & Paardenbloem & Taraxacum officinale & 1 & 3 & 6 & 14 & -3 \\
\hline Vaatplanten & Moerasbeemdgras & Poa palustris & 11 & 4 & 7 & 2 & -3 \\
\hline Vaatplanten & IJle dravik & Anisantha sterilis & 9 & 4 & 7 & 4 & -3 \\
\hline Vaatplanten & Gewoon biggenkruid & Hypochaeris radicata & 9 & 4 & 7 & 4 & -3 \\
\hline Vaatplanten & Katwilg & Salix viminalis & 7 & 4 & 7 & 6 & -3 \\
\hline Vaatplanten & Eenstijlige meidoorn & Crataegus monogyna & 4 & 4 & 7 & 9 & -3 \\
\hline Vaatplanten & Kleefkruid & Galium aparine & 4 & 4 & 7 & 9 & -3 \\
\hline Vaatplanten & Duizendblad & Achillea millefolium & 1 & 4 & 7 & 12 & -3 \\
\hline Vaatplanten & Gewone margriet & Leucanthemum vulgare & 1 & 4 & 7 & 12 & -3 \\
\hline
\end{tabular}




\begin{tabular}{|c|c|c|c|c|c|c|c|}
\hline srtgroepen & soort_ned & soort_wet & not & & na & $+n=$ & vr-na \\
\hline Vaatplanten & Gewoon struisgras & Agrostis capillaris & 7 & 5 & 8 & 4 & -3 \\
\hline Vaatplanten & Rood zwenkgras & Festuca rubra & 3 & 5 & 8 & 8 & -3 \\
\hline Vaatplanten & Waterzuring & Rumex hydrolapathum & 4 & 6 & 9 & 5 & -3 \\
\hline Vaatplanten & Bolderik & Agrostemma githago & 20 & 0 & 4 & 0 & -4 \\
\hline Vaatplanten & Hartbladige els & Alnus cordata & 20 & 0 & 4 & 0 & -4 \\
\hline Vaatplanten & Spoorbloem & Centranthus ruber & 20 & 0 & 4 & 0 & -4 \\
\hline Vaatplanten & Taxus & Taxus baccata & 20 & 0 & 4 & 0 & -4 \\
\hline Vaatplanten & Kleine maagdenpalm & Vinca minor & 20 & 0 & 4 & 0 & -4 \\
\hline Vaatplanten & Tuinviooltje & Viola tricolor 'Hortensis' & 20 & 0 & 4 & 0 & -4 \\
\hline Vaatplanten & Grote waternavel & Hydrocotyle ranunculoides & 19 & 0 & 4 & 1 & -4 \\
\hline Vaatplanten & Smal beemdgras & Poa angustifolia & 19 & 0 & 4 & 1 & -4 \\
\hline Vaatplanten & Gele helmbloem & Pseudofumaria lutea & 19 & 0 & 4 & 1 & -4 \\
\hline Vaatplanten & Rosse vossenstaart & Alopecurus aequalis & 18 & 0 & 4 & 2 & -4 \\
\hline Vaatplanten & Vijfdelig kaasjeskruid & Malva alcea & 18 & 0 & 4 & 2 & -4 \\
\hline Vaatplanten & Rimpelroos & Rosa rugosa & 18 & 0 & 4 & 2 & -4 \\
\hline Vaatplanten & Heggendoornzaad & Torilis japonica & 18 & 0 & 4 & 2 & -4 \\
\hline Vaatplanten & Vergeten wikke & Vicia sativa subsp. segetalis & 18 & 0 & 4 & 2 & -4 \\
\hline Vaatplanten & Muurleeuwenbek & Cymbalaria muralis & 17 & 0 & 4 & 3 & -4 \\
\hline Vaatplanten & Hondspeterselie & Aethusa cynapium & 16 & 0 & 4 & 4 & -4 \\
\hline Vaatplanten & Bont kroonkruid & Securigera varia & 16 & 0 & 4 & 4 & -4 \\
\hline Vaatplanten & Moederkruid & Tanacetum parthenium & 18 & 1 & 5 & 0 & -4 \\
\hline Vaatplanten & Draadereprijs & Veronica filiformis & 18 & 1 & 5 & 0 & -4 \\
\hline Vaatplanten & Franse amarant & Amaranthus bouchonii & 17 & 1 & 5 & 1 & -4 \\
\hline Vaatplanten & Riviertandzaad & Bidens radiata & 17 & 1 & 5 & 1 & -4 \\
\hline Vaatplanten & Bosveldkers & Cardamine flexuosa & 17 & 1 & 5 & 1 & -4 \\
\hline Vaatplanten & Tengere rus & Juncus tenuis & 17 & 1 & 5 & 1 & -4 \\
\hline Vaatplanten & Kandelaartje & Saxifraga tridactylites & 17 & 1 & 5 & 1 & -4 \\
\hline Vaatplanten & Robinia & Robinia pseudoacacia & 16 & 1 & 5 & 2 & -4 \\
\hline Vaatplanten & Zonnebloem & Helianthus annuus & 15 & 1 & 5 & 3 & -4 \\
\hline Vaatplanten & Bosbies & Scirpus sylvaticus & 15 & 1 & 5 & 3 & -4 \\
\hline Vaatplanten & Kransnaaldaar & Setaria verticillata & 15 & 1 & 5 & 3 & -4 \\
\hline Vaatplanten & Papegaaienkruid & Amaranthus retroflexus & 14 & 1 & 5 & 4 & -4 \\
\hline Vaatplanten & Groot hoefblad & Petasites hybridus & 14 & 1 & 5 & 4 & -4 \\
\hline Vaatplanten & Kleine veldkers & Cardamine hirsuta & 11 & 1 & 5 & 7 & -4 \\
\hline Vaatplanten & Uitstaande melde & Atriplex patula & 9 & 1 & 5 & 9 & -4 \\
\hline Vaatplanten & Hop & Humulus lupulus & 9 & 1 & 5 & 9 & -4 \\
\hline Vaatplanten & Reuzenbalsemien & Impatiens glandulifera & 9 & 1 & 5 & 9 & -4 \\
\hline Vaatplanten & Beemdkroon & Knautia arvensis & 9 & 1 & 5 & 9 & -4 \\
\hline Vaatplanten & Schijfkamille & Matricaria discoidea & 9 & 1 & 5 & 9 & -4 \\
\hline Vaatplanten & Klein kruiskruid & Senecio vulgaris & 8 & 1 & 5 & 10 & -4 \\
\hline Vaatplanten & Goudhaver & Trisetum flavescens & 8 & 1 & 5 & 10 & -4 \\
\hline Vaatplanten & Brede lathyrus & Lathyrus latifolius & 16 & 2 & 6 & 0 & -4 \\
\hline Vaatplanten & Wilde kardinaalsmuts & Euonymus europaeus & 15 & 2 & 6 & 1 & -4 \\
\hline Vaatplanten & Schapenzuring & Rumex acetosella & 15 & 2 & 6 & 1 & -4 \\
\hline Vaatplanten & Koningskaars & Verbascum thapsus & 15 & 2 & 6 & 1 & -4 \\
\hline Vaatplanten & Gekroesd fonteinkruid & Potamogeton crispus & 14 & 2 & 6 & 2 & -4 \\
\hline Vaatplanten & Aardbeiklaver & Trifolium fragiferum & 14 & 2 & 6 & 2 & -4 \\
\hline Vaatplanten & Zwaluwtong & Fallopia convolvulus & 13 & 2 & 6 & 3 & -4 \\
\hline Vaatplanten & Moeraswalstro & Galium palustre & 12 & 2 & 6 & 4 & -4 \\
\hline Vaatplanten & Peperkers & Lepidium latifolium & 12 & 2 & 6 & 4 & -4 \\
\hline Vaatplanten & Dagkoekoeksbloem & Silene dioica & 12 & 2 & 6 & 4 & -4 \\
\hline Vaatplanten & Kleine leeuwenbek & Chaenorhinum minus & 11 & 2 & 6 & 5 & -4 \\
\hline Vaatplanten & Kompassla & Lactuca serriola & 11 & 2 & 6 & 5 & -4 \\
\hline Vaatplanten & Wilgenroosje & Chamerion angustifolium & 10 & 2 & 6 & 6 & -4 \\
\hline Vaatplanten & Grote klit & Arctium lappa & 9 & 2 & 6 & 7 & -4 \\
\hline Vaatplanten & Zwarte nachtschade & Solanum nigrum subsp. nigrum & 9 & 2 & 6 & 7 & -4 \\
\hline Vaatplanten & Echte kamille & Matricaria chamomilla & 7 & 2 & 6 & 9 & -4 \\
\hline Vaatplanten & Straatgras & Poa annua & 5 & 2 & 6 & 11 & -4 \\
\hline Vaatplanten & Zilverschoon & Potentilla anserina & 4 & 2 & 6 & 12 & -4 \\
\hline Vaatplanten & Kruipende boterbloem & Ranunculus repens & 4 & 2 & 6 & 12 & -4 \\
\hline Vaatplanten & Knoopkruid & Centaurea jacea & 1 & 2 & 6 & 15 & -4 \\
\hline Vaatplanten & Glad walstro & Galium mollugo & 1 & 2 & 6 & 15 & -4 \\
\hline Vaatplanten & Grote brandnetel & Urtica dioica & 1 & 2 & 6 & 15 & -4 \\
\hline Vaatplanten & Italiaans raaigras & Lolium multiflorum & 12 & 3 & 7 & 2 & -4 \\
\hline
\end{tabular}




\begin{tabular}{|c|c|c|c|c|c|c|c|}
\hline srtgroepen & soort_ned & soort_wet & not & \multicolumn{4}{|c|}{ vr na vr+na vr-na } \\
\hline Vaatplanten & Gewone duivenkervel & Fumaria officinalis & 11 & 3 & 7 & 3 & -4 \\
\hline Vaatplanten & Schedefonteinkruid & Potamogeton pectinatus & 11 & 3 & 7 & 3 & -4 \\
\hline Vaatplanten & Gewone braam & Rubus fruticosus & 8 & 3 & 7 & 6 & -4 \\
\hline Vaatplanten & Late guldenroede & Solidago gigantea & 7 & 3 & 7 & 7 & -4 \\
\hline Vaatplanten & Beklierde duizendknoop & Persicaria lapathifolia & 6 & 3 & 7 & 8 & -4 \\
\hline Vaatplanten & Gewone bermzegge & Carex spicata & 5 & 3 & 7 & 9 & -4 \\
\hline Vaatplanten & Grote wederik & Lysimachia vulgaris & 5 & 3 & 7 & 9 & -4 \\
\hline Vaatplanten & Akkerwinde & Convolvulus arvensis & 4 & 3 & 7 & 10 & -4 \\
\hline Vaatplanten & Haagwinde & Convolvulus sepium & 4 & 3 & 7 & 10 & -4 \\
\hline Vaatplanten & Zwart tandzaad & Bidens frondosa & 3 & 3 & 7 & 11 & -4 \\
\hline Vaatplanten & Akkerdistel & Cirsium arvense & 1 & 3 & 7 & 13 & -4 \\
\hline Vaatplanten & Grote engelwortel & Angelica archangelica & 10 & 4 & 8 & 2 & -4 \\
\hline Vaatplanten & Gele plomp & Nuphar lutea & 8 & 4 & 8 & 4 & -4 \\
\hline Vaatplanten & Vlasbekje & Linaria vulgaris & 4 & 4 & 8 & 8 & -4 \\
\hline Vaatplanten & Gele lis & Iris pseudacorus & 2 & 4 & 8 & 10 & -4 \\
\hline Vaatplanten & Vertakte leeuwentand & Leontodon autumnalis & 4 & & 10 & 4 & -4 \\
\hline Vaatplanten & Gele kamille & Anthemis tinctoria & 19 & 0 & 5 & 0 & -5 \\
\hline Vaatplanten & Schijngenadekruid & Lindernia dubia & 19 & 0 & 5 & 0 & -5 \\
\hline Vaatplanten & Brandpastinaak & Pastinaca sativa subsp. urens & 19 & 0 & 5 & 0 & -5 \\
\hline Vaatplanten & Oosterse karmozijnbes & Phytolacca esculenta & 19 & 0 & 5 & 0 & -5 \\
\hline Vaatplanten & Schijnaardbei & Potentilla indica & 19 & 0 & 5 & 0 & -5 \\
\hline Vaatplanten & Fluweelblad & Abutilon theophrasti & 18 & 0 & 5 & 1 & -5 \\
\hline Vaatplanten & Steenbreekvaren & Asplenium trichomanes & 18 & 0 & 5 & 1 & -5 \\
\hline Vaatplanten & Witte abeel & Populus alba & 18 & 0 & 5 & 1 & -5 \\
\hline Vaatplanten & Uitstaande vetmuur & Sagina micropetala & 18 & 0 & 5 & 1 & -5 \\
\hline Vaatplanten & Gewoon sneeuwklokje & Galanthus nivalis & 17 & 0 & 5 & 2 & -5 \\
\hline Vaatplanten & Groene naaldaar & Setaria viridis & 17 & 0 & 5 & 2 & -5 \\
\hline Vaatplanten & Gewoon langbaardgras & Vulpia myuros & 17 & 0 & 5 & 2 & -5 \\
\hline Vaatplanten & Maasraket & Sisymbrium austriacum subsp. chrysanthum & 16 & 0 & 5 & 3 & -5 \\
\hline Vaatplanten & Rechte alsem & Artemisia biennis & 15 & 0 & 5 & 4 & -5 \\
\hline Vaatplanten & Tongvaren & Asplenium scolopendrium & 15 & 0 & 5 & 4 & -5 \\
\hline Vaatplanten & Fraai duizendguldenkruid & Centaurium pulchellum & 15 & 0 & 5 & 4 & -5 \\
\hline Vaatplanten & Slijkgroen & Limosella aquatica & 14 & 0 & 5 & 5 & -5 \\
\hline Vaatplanten & Rivierfonteinkruid & Potamogeton nodosus & 14 & 0 & 5 & 5 & -5 \\
\hline Vaatplanten & Zwarte toorts & Verbascum nigrum & 10 & 0 & 5 & 9 & -5 \\
\hline Vaatplanten & Geelrode naaldaar & Setaria pumila & 17 & 1 & 6 & 0 & -5 \\
\hline Vaatplanten & Rode schijnspurrie & Spergularia rubra & 17 & 1 & 6 & 0 & -5 \\
\hline Vaatplanten & Harig vingergras & Digitaria sanguinalis & 16 & 1 & 6 & 1 & -5 \\
\hline Vaatplanten & Naaldwaterbies & Eleocharis acicularis & 15 & 1 & 6 & 2 & -5 \\
\hline Vaatplanten & Stijve klaverzuring & Oxalis stricta & 15 & 1 & 6 & 2 & -5 \\
\hline Vaatplanten & Zegekruid & Nicandra physalodes & 14 & 1 & 6 & 3 & -5 \\
\hline Vaatplanten & Reigersbek & Erodium cicutarium & 13 & 1 & 6 & 4 & -5 \\
\hline Vaatplanten & Kleine ooievaarsbek & Geranium pusillum & 13 & 1 & 6 & 4 & -5 \\
\hline Vaatplanten & Vederesdoorn & Acer negundo & 12 & 1 & 6 & 5 & -5 \\
\hline Vaatplanten & Gewoon reukgras & Anthoxanthum odoratum & 12 & 1 & 6 & 5 & -5 \\
\hline Vaatplanten & Reuzenberenklauw & Heracleum mantegazzianum & 12 & 1 & 6 & 5 & -5 \\
\hline Vaatplanten & Bleke klaproos & Papaver dubium & 12 & 1 & 6 & 5 & -5 \\
\hline Vaatplanten & Spaanse aak & Acer campestre & 11 & 1 & 6 & 6 & -5 \\
\hline Vaatplanten & Bermooievaarsbek & Geranium pyrenaicum & 11 & 1 & 6 & 6 & -5 \\
\hline Vaatplanten & Klein kroos & Lemna minor & 11 & 1 & 6 & 6 & -5 \\
\hline Vaatplanten & Bosrank & Clematis vitalba & 10 & 1 & 6 & 7 & -5 \\
\hline Vaatplanten & IJzerhard & Verbena officinalis & 10 & 1 & 6 & 7 & -5 \\
\hline Vaatplanten & Grasklokje & Campanula rotundifolia & 9 & 1 & 6 & 8 & -5 \\
\hline Vaatplanten & Bezemkruiskruid & Senecio inaequidens & 7 & 1 & 6 & 10 & -5 \\
\hline Vaatplanten & Witte dovenetel & Lamium album & 6 & 1 & 6 & 11 & -5 \\
\hline Vaatplanten & Watermunt & Mentha aquatica & 4 & 1 & 6 & 13 & -5 \\
\hline Vaatplanten & Ruwe berk & Betula pendula & 13 & 2 & 7 & 2 & -5 \\
\hline Vaatplanten & Zandraket & Arabidopsis thaliana & 12 & 2 & 7 & 3 & -5 \\
\hline Vaatplanten & Gewone zandmuur & Arenaria serpyllifolia & 12 & 2 & 7 & 3 & -5 \\
\hline Vaatplanten & Zwarte populier & Populus nigra & 12 & 2 & 7 & 3 & -5 \\
\hline Vaatplanten & Zwanenbloem & Butomus umbellatus & 11 & 2 & 7 & 4 & -5 \\
\hline Vaatplanten & Geel nagelkruid & Geum urbanum & 11 & 2 & 7 & 4 & -5 \\
\hline Vaatplanten & Harig knopkruid & Galinsoga quadriradiata & 9 & 2 & 7 & 6 & -5 \\
\hline Vaatplanten & Grote waterweegbree & Alisma plantago-aquatica & 8 & 2 & 7 & 7 & -5 \\
\hline
\end{tabular}




\begin{tabular}{|c|c|c|c|c|c|c|c|}
\hline srtgroepen & soort_ned & soort_wet & not & & na & $r+n t$ & a vr-na \\
\hline Vaatplanten & Riet & Phragmites australis & 7 & 2 & 7 & 8 & -5 \\
\hline Vaatplanten & Gele waterkers & Rorippa amphibia & 6 & 2 & 7 & 9 & -5 \\
\hline Vaatplanten & Speerdistel & Cirsium vulgare & 5 & 2 & 7 & 10 & -5 \\
\hline Vaatplanten & Es & Fraxinus excelsior & 5 & 2 & 7 & 10 & -5 \\
\hline Vaatplanten & Geel walstro & Galium verum & 5 & 2 & 7 & 10 & -5 \\
\hline Vaatplanten & Madeliefje & Bellis perennis & 4 & 2 & 7 & 11 & -5 \\
\hline Vaatplanten & Kaal knopkruid & Galinsoga parviflora & 11 & 3 & 8 & 2 & -5 \\
\hline Vaatplanten & Klein kaasjeskruid & Malva neglecta & 11 & 3 & 8 & 2 & -5 \\
\hline Vaatplanten & Echte koekoeksbloem & Silene flos-cuculi & 11 & 3 & 8 & 2 & -5 \\
\hline Vaatplanten & Grote klaproos & Papaver rhoeas & 9 & 3 & 8 & 4 & -5 \\
\hline Vaatplanten & Wilde reseda & Reseda lutea & 8 & 3 & 8 & 5 & -5 \\
\hline Vaatplanten & Kluwenzuring & Rumex conglomeratus & 8 & 3 & 8 & 5 & -5 \\
\hline Vaatplanten & Late stekelnoot & Xanthium strumarium & 8 & 3 & 8 & 5 & -5 \\
\hline Vaatplanten & Moerasspirea & Filipendula ulmaria & 6 & 3 & 8 & 7 & -5 \\
\hline Vaatplanten & Wit vetkruid & Sedum album & 6 & 3 & 8 & 7 & -5 \\
\hline Vaatplanten & Gewone melkdistel & Sonchus oleraceus & 6 & 3 & 8 & 7 & -5 \\
\hline Vaatplanten & Gewoon speenkruid & Ficaria verna subsp. verna & 5 & 3 & 8 & 8 & -5 \\
\hline Vaatplanten & Zomereik & Quercus robur & 5 & 3 & 8 & 8 & -5 \\
\hline Vaatplanten & Hopklaver & Medicago lupulina & 4 & 3 & 8 & 9 & -5 \\
\hline Vaatplanten & Krulzuring & Rumex crispus & 4 & 3 & 8 & 9 & -5 \\
\hline Vaatplanten & Vijfvingerkruid & Potentilla reptans & 2 & 3 & 8 & 11 & -5 \\
\hline Vaatplanten & Muskuskaasjeskruid & Malva moschata & 8 & 4 & 9 & 3 & -5 \\
\hline Vaatplanten & Aziatische veldkers & Cardamine occulta & 18 & 0 & 6 & 0 & -6 \\
\hline Vaatplanten & Echt duizendguldenkruid & Centaurium erythraea & 18 & 0 & 6 & 0 & -6 \\
\hline Vaatplanten & Duits viltkruid & Filago vulgaris & 18 & 0 & 6 & 0 & -6 \\
\hline Vaatplanten & Amerikaanse kruidkers & Lepidium virginicum & 18 & 0 & 6 & 0 & -6 \\
\hline Vaatplanten & Dubbelkelk & Picris echioides & 18 & 0 & 6 & 0 & -6 \\
\hline Vaatplanten & Stijf ijzerhard & Verbena bonariensis & 18 & 0 & 6 & 0 & -6 \\
\hline Vaatplanten & Vreemde ereprijs & Veronica peregrina & 18 & 0 & 6 & 0 & -6 \\
\hline Vaatplanten & Alsemambrosia & Ambrosia artemisiifolia & 17 & 0 & 6 & 1 & -6 \\
\hline Vaatplanten & Grote teunisbloem & Oenothera glazioviana & 17 & 0 & 6 & 1 & -6 \\
\hline Vaatplanten & Hertshoornweegbree & Plantago coronopus & 17 & 0 & 6 & 1 & -6 \\
\hline Vaatplanten & Bosandoorn & Stachys sylvatica & 15 & 0 & 6 & 3 & -6 \\
\hline Vaatplanten & Gelderse roos & Viburnum opulus & 13 & 0 & 6 & 5 & -6 \\
\hline Vaatplanten & Gewone engelwortel & Angelica sylvestris & 12 & 0 & 6 & 6 & -6 \\
\hline Vaatplanten & Europese hanenpoot & Echinochloa crus-galli & 12 & 0 & 6 & 6 & -6 \\
\hline Vaatplanten & Glad vingergras & Digitaria ischaemum & 15 & 1 & 7 & 1 & -6 \\
\hline Vaatplanten & Oranje havikskruid & Hieracium aurantiacum & 15 & 1 & 7 & 1 & -6 \\
\hline Vaatplanten & Liggende vetmuur & Sagina procumbens & 14 & 1 & 7 & 2 & -6 \\
\hline Vaatplanten & Stippelganzenvoet & Chenopodium ficifolium & 13 & 1 & 7 & 3 & -6 \\
\hline Vaatplanten & Gewone klit & Arctium minus & 12 & 1 & 7 & 4 & -6 \\
\hline Vaatplanten & Klimop & Hedera helix & 11 & 1 & 7 & 5 & -6 \\
\hline Vaatplanten & Greppelrus & Juncus bufonius & 11 & 1 & 7 & 5 & -6 \\
\hline Vaatplanten & Platte rus & Juncus compressus & 11 & 1 & 7 & 5 & -6 \\
\hline Vaatplanten & Gewone esdoorn & Acer pseudoplatanus & 10 & 1 & 7 & 6 & -6 \\
\hline Vaatplanten & Zachte ooievaarsbek & Geranium molle & 8 & 1 & 7 & 8 & -6 \\
\hline Vaatplanten & Paarse dovenetel & Lamium purpureum & 8 & 1 & 7 & 8 & -6 \\
\hline Vaatplanten & Perzikkruid & Persicaria maculosa & 8 & 1 & 7 & 8 & -6 \\
\hline Vaatplanten & Fioringras & Agrostis stolonifera & 7 & 1 & 7 & 9 & -6 \\
\hline Vaatplanten & Veerdelig tandzaad & Bidens tripartita & 7 & 1 & 7 & 9 & -6 \\
\hline Vaatplanten & Peen & Daucus carota & 4 & 1 & 7 & 12 & -6 \\
\hline Vaatplanten & Wilde bertram & Achillea ptarmica & 1 & 1 & 7 & 15 & -6 \\
\hline Vaatplanten & Jakobskruiskruid & Jacobaea vulgaris & 1 & 1 & 7 & 15 & -6 \\
\hline Vaatplanten & Kransmunt & Mentha $x$ verticillata & 13 & 2 & 8 & 1 & -6 \\
\hline Vaatplanten & Witte honingklaver & Melilotus albus & 12 & 2 & 8 & 2 & -6 \\
\hline Vaatplanten & Aalbes & Ribes rubrum & 11 & 2 & 8 & 3 & -6 \\
\hline Vaatplanten & Moeraszuring & Rumex palustris & 11 & 2 & 8 & 3 & -6 \\
\hline Vaatplanten & Amandelwilg & Salix triandra & 11 & 2 & 8 & 3 & -6 \\
\hline Vaatplanten & Slipbladige ooievaarsbek & Geranium dissectum & 10 & 2 & 8 & 4 & -6 \\
\hline Vaatplanten & Getande weegbree & Plantago major subsp. intermedia & 10 & 2 & 8 & 4 & -6 \\
\hline Vaatplanten & Vroegeling & Erophila verna & 9 & 2 & 8 & 5 & -6 \\
\hline Vaatplanten & Goudzuring & Rumex maritimus & 9 & 2 & 8 & 5 & -6 \\
\hline Vaatplanten & Zomerfijnstraal & Erigeron annuus & 8 & 2 & 8 & 6 & -6 \\
\hline Vaatplanten & Moerasdroogbloem & Gnaphalium uliginosum & 8 & 2 & 8 & 6 & -6 \\
\hline
\end{tabular}




\begin{tabular}{|c|c|c|c|c|c|c|c|}
\hline srtgroepen & soort_ned & soort_wet & not & \multicolumn{4}{|c|}{ vr na vr+na vr-na } \\
\hline Vaatplanten & Grauwe wilg s.l. & Salix cinerea & 8 & 2 & 8 & 6 & -6 \\
\hline Vaatplanten & Klein hoefblad & Tussilago farfara & 6 & 2 & 8 & 8 & -6 \\
\hline Vaatplanten & Wilde marjolein & Origanum vulgare & 5 & 2 & 8 & 9 & -6 \\
\hline Vaatplanten & Reukeloze kamille & Tripleurospermum maritimum & 3 & 2 & 8 & 11 & -6 \\
\hline Vaatplanten & Zachte duizendknoop & Persicaria mitis & 11 & 3 & 9 & 1 & -6 \\
\hline Vaatplanten & Gewone waterbies & Eleocharis palustris & 10 & 3 & 9 & 2 & -6 \\
\hline Vaatplanten & Akkermelkdistel & Sonchus arvensis & 8 & 3 & 9 & 4 & -6 \\
\hline Vaatplanten & Veldereprijs & Veronica arvensis & 8 & 3 & 9 & 4 & -6 \\
\hline Vaatplanten & Spiesmelde & Atriplex prostrata & 6 & 3 & 9 & 6 & -6 \\
\hline Vaatplanten & Valse voszegge & Carex otrubae & 5 & 3 & 9 & 7 & -6 \\
\hline Vaatplanten & Rode kornoelje & Cornus sanguinea & 5 & 3 & 9 & 7 & -6 \\
\hline Vaatplanten & Moerasandoorn & Stachys palustris & 3 & 3 & 9 & 9 & -6 \\
\hline Vaatplanten & Waterpeper & Persicaria hydropiper & 5 & 4 & 10 & 5 & -6 \\
\hline Vaatplanten & Hulst & Ilex aquifolium & 16 & 0 & 7 & 1 & -7 \\
\hline Vaatplanten & Zandteunisbloem & Oenothera deflexa & 16 & 0 & 7 & 1 & -7 \\
\hline Vaatplanten & Wegdistel & Onopordum acanthium & 16 & 0 & 7 & 1 & -7 \\
\hline Vaatplanten & Bleekgele droogbloem & Gnaphalium luteoalbum & 15 & 0 & 7 & 2 & -7 \\
\hline Vaatplanten & Tuinwolfsmelk & Euphorbia peplus & 14 & 0 & 7 & 3 & -7 \\
\hline Vaatplanten & Welriekende ganzenvoet & Chenopodium ambrosioides & 13 & 0 & 7 & 4 & -7 \\
\hline Vaatplanten & Basterdklaver & Trifolium hybridum & 13 & 0 & 7 & 4 & -7 \\
\hline Vaatplanten & Sleedoorn & Prunus spinosa & 11 & 0 & 7 & 6 & -7 \\
\hline Vaatplanten & Zwarte els & Alnus glutinosa & 8 & 0 & 7 & 9 & -7 \\
\hline Vaatplanten & Kruisbladwalstro & Cruciata laevipes & 8 & 0 & 7 & 9 & -7 \\
\hline Vaatplanten & Stalkaars & Verbascum densiflorum & 14 & 1 & 8 & 1 & -7 \\
\hline Vaatplanten & Rood guichelheil & Anagallis arvensis subsp. arvensis & 12 & 1 & 8 & 3 & -7 \\
\hline Vaatplanten & Liggende klaver & Trifolium campestre & 12 & 1 & 8 & 3 & -7 \\
\hline Vaatplanten & Korrelganzenvoet & Chenopodium polyspermum & 10 & 1 & 8 & 5 & -7 \\
\hline Vaatplanten & Grote egelskop & Sparganium erectum & 10 & 1 & 8 & 5 & -7 \\
\hline Vaatplanten & Klimopereprijs & Veronica hederifolia & 10 & 1 & 8 & 5 & -7 \\
\hline Vaatplanten & Penningkruid & Lysimachia nummularia & 9 & 1 & 8 & 6 & -7 \\
\hline Vaatplanten & Goudgele honingklaver & Melilotus altissimus & 9 & 1 & 8 & 6 & -7 \\
\hline Vaatplanten & Moeraskers & Rorippa palustris & 9 & 1 & 8 & 6 & -7 \\
\hline Vaatplanten & Zeepkruid & Saponaria officinalis & 9 & 1 & 8 & 6 & -7 \\
\hline Vaatplanten & Stinkende gouwe & Chelidonium majus & 8 & 1 & 8 & 7 & -7 \\
\hline Vaatplanten & Kraailook & Allium vineale & 6 & 1 & 8 & 9 & -7 \\
\hline Vaatplanten & Groot streepzaad & Crepis biennis & 6 & 1 & 8 & 9 & -7 \\
\hline Vaatplanten & Harig wilgenroosje & Epilobium hirsutum & 6 & 1 & 8 & 9 & -7 \\
\hline Vaatplanten & Koninginnekruid & Eupatorium cannabinum & 6 & 1 & 8 & 9 & -7 \\
\hline Vaatplanten & Zomprus & Juncus articulatus & 10 & 2 & 9 & 3 & -7 \\
\hline Vaatplanten & Pitrus & Juncus effusus & 8 & 2 & 9 & 5 & -7 \\
\hline Vaatplanten & Gewone ereprijs & Veronica chamaedrys & 8 & 2 & 9 & 5 & -7 \\
\hline Vaatplanten & Geoord helmkruid & Scrophularia auriculata & 7 & 2 & 9 & 6 & -7 \\
\hline Vaatplanten & Gekroesde melkdistel & Sonchus asper & 6 & 2 & 9 & 7 & -7 \\
\hline Vaatplanten & Kluwenhoornbloem & Cerastium glomeratum & 5 & 2 & 9 & 8 & -7 \\
\hline Vaatplanten & Melganzenvoet & Chenopodium album & 5 & 2 & 9 & 8 & -7 \\
\hline Vaatplanten & Watermuur & Myosoton aquaticum & 4 & 2 & 9 & 9 & -7 \\
\hline Vaatplanten & Grote weegbree & Plantago major subsp. major & 4 & 2 & 9 & 9 & -7 \\
\hline Vaatplanten & Wolfspoot & Lycopus europaeus & 3 & 2 & 9 & 10 & -7 \\
\hline Vaatplanten & Moerasrolklaver & Lotus pedunculatus & 8 & 3 & 10 & 3 & -7 \\
\hline Vaatplanten & Gewone hennepnetel & Galeopsis tetrahit & 7 & 3 & 10 & 4 & -7 \\
\hline Vaatplanten & Muurpeper & Sedum acre & 5 & 3 & 10 & 6 & -7 \\
\hline Vaatplanten & Grote kaardebol & Dipsacus fullonum & 3 & 3 & 10 & 8 & -7 \\
\hline Vaatplanten & Klein streepzaad & Crepis capillaris & 3 & 4 & 11 & 6 & -7 \\
\hline Vaatplanten & Klein liefdegras & Eragrostis minor & 16 & 0 & 8 & 0 & -8 \\
\hline Vaatplanten & Postelein & Portulaca oleracea & 14 & 0 & 8 & 2 & -8 \\
\hline Vaatplanten & Beklierde basterdwederik & Epilobium ciliatum & 12 & 0 & 8 & 4 & -8 \\
\hline Vaatplanten & Heggenrank & Bryonia dioica & 9 & 0 & 8 & 7 & -8 \\
\hline Vaatplanten & Hoge fijnstraal & Conyza sumatrensis & 14 & 1 & 9 & 0 & -8 \\
\hline Vaatplanten & Akkerereprijs & Veronica agrestis & 14 & 1 & 9 & 0 & -8 \\
\hline Vaatplanten & Citroengele honingklaver & Melilotus officinalis & 13 & 1 & 9 & 1 & -8 \\
\hline Vaatplanten & Kruipertje & Hordeum murinum & 12 & 1 & 9 & 2 & -8 \\
\hline Vaatplanten & Aarvederkruid & Myriophyllum spicatum & 12 & 1 & 9 & 2 & -8 \\
\hline Vaatplanten & Tuinbingelkruid & Mercurialis annua & 11 & 1 & 9 & 3 & -8 \\
\hline Vaatplanten & Grote ereprijs & Veronica persica & 10 & 1 & 9 & 4 & -8 \\
\hline
\end{tabular}




\begin{tabular}{|c|c|c|c|c|c|c|c|}
\hline srtgroepen & soort_ned & soort_wet & not & \multicolumn{4}{|c|}{ vr na vr+na vr-na } \\
\hline Vaatplanten & Boswilg & Salix caprea & 9 & 1 & 9 & 5 & -8 \\
\hline Vaatplanten & Okkernoot & Juglans regia & 8 & 1 & 9 & 6 & -8 \\
\hline Vaatplanten & Beekpunge & Veronica beccabunga & 8 & 1 & 9 & 6 & -8 \\
\hline Vaatplanten & Rode waterereprijs & Veronica catenata & 7 & 1 & 9 & 7 & -8 \\
\hline Vaatplanten & Pinksterbloem & Cardamine pratensis & 5 & 1 & 9 & 9 & -8 \\
\hline Vaatplanten & Canadese fijnstraal & Conyza canadensis & 5 & 1 & 9 & 9 & -8 \\
\hline Vaatplanten & Gewone vogelmelk & Ornithogalum umbellatum & 5 & 1 & 9 & 9 & -8 \\
\hline Vaatplanten & Kantige basterdwederik & Epilobium tetragonum & 8 & & 10 & 4 & -8 \\
\hline Vaatplanten & Smalle aster s.l. & Aster lanceolatus / ontorionis & 6 & & 10 & 6 & -8 \\
\hline Vaatplanten & Heelblaadjes & Pulicaria dysenterica & 4 & & 10 & 8 & -8 \\
\hline Vaatplanten & Poelruit & Thalictrum flavum & 2 & & 10 & 10 & -8 \\
\hline Vaatplanten & Wilde cichorei & Cichorium intybus & 3 & & 11 & 7 & -8 \\
\hline Vaatplanten & Gehoornde klaverzuring & Oxalis corniculata & 14 & 0 & 9 & 1 & -9 \\
\hline Vaatplanten & Muurvaren & Asplenium ruta-muraria & 13 & 0 & 9 & 2 & -9 \\
\hline Vaatplanten & Veldsla & Valerianella locusta & 12 & 0 & 9 & 3 & -9 \\
\hline Vaatplanten & Duinriet & Calamagrostis epigejos & 11 & & 10 & 2 & -9 \\
\hline Vaatplanten & Wouw & Reseda luteola & 11 & & 10 & 2 & -9 \\
\hline Vaatplanten & Kleine brandnetel & Urtica urens & 11 & & 10 & 2 & -9 \\
\hline Vaatplanten & Knikkend tandzaad & Bidens cernua & 10 & & 10 & 3 & -9 \\
\hline Vaatplanten & Bruin cypergras & Cyperus fuscus & 9 & & 10 & 4 & -9 \\
\hline Vaatplanten & Zeegroene rus & Juncus inflexus & 8 & & 10 & 5 & -9 \\
\hline Vaatplanten & Blaartrekkende boterbloem & Ranunculus sceleratus & 8 & & 10 & 5 & -9 \\
\hline Vaatplanten & Echte valeriaan & Valeriana officinalis & 4 & & 10 & 9 & -9 \\
\hline Vaatplanten & Moerasvergeet-mij-nietje & Myosotis scorpioides subsp. scorpioides & 4 & & 11 & 7 & -9 \\
\hline Vaatplanten & Vlinderstruik & Buddleja davidii & 12 & & 10 & 2 & -10 \\
\hline Vaatplanten & Blauw glidkruid & Scutellaria galericulata & 10 & & 10 & 4 & -10 \\
\hline Vaatplanten & Rode ogentroost & Odontites vernus subsp. serotinus & 7 & & 10 & 7 & -10 \\
\hline Vaatplanten & Hazenpootje & Trifolium arvense & 8 & & 12 & 2 & -10 \\
\hline Vaatplanten & Rode ganzenvoet & Chenopodium rubrum & 6 & & 12 & 4 & -10 \\
\hline Vaatplanten & Gewone brunel & Prunella vulgaris & 6 & & 12 & 4 & -10 \\
\hline Vaatplanten & Kroontjeskruid & Euphorbia helioscopia & 8 & & 12 & 3 & -11 \\
\hline Vaatplanten & Blauwe waterereprijs & Veronica anagallis-aquatica & 6 & & 12 & 6 & -12 \\
\hline Vaatplanten & Viltige basterdwederik & Epilobium parviflorum & 9 & & 13 & 1 & -12 \\
\hline Vaatplanten & Tijmereprijs & Veronica serpyllifolia & 7 & & 13 & 3 & -12 \\
\hline Vissen & Ruisvoorn & Scardinius erythrophthalmus & 12 & 9 & 1 & 2 & 8 \\
\hline Vissen & Pos & Gymnocephalus cernua & 12 & 10 & 2 & 0 & 8 \\
\hline Vissen & Paling & Anguilla anguilla & 7 & 9 & 2 & 6 & 7 \\
\hline Vissen & Zeelt & Tinca tinca & 9 & 9 & 3 & 3 & 6 \\
\hline Vissen & Blankvoorn & Rutilus rutilus & 5 & 7 & 2 & 10 & 5 \\
\hline Vissen & Cottus & Cottus gobio & 20 & 4 & 0 & 0 & 4 \\
\hline Vissen & Giebel & Carassius gibelio & 18 & 5 & 1 & 0 & 4 \\
\hline Vissen & Riviergrondel & Gobio gobio & 14 & 5 & 1 & 4 & 4 \\
\hline Vissen & Alver & Alburnus alburnus & 13 & 6 & 2 & 3 & 4 \\
\hline Vissen & Baars & Perca fluviatilis & 5 & 6 & 2 & 11 & 4 \\
\hline Vissen & Giebel/Goudvis & Carassius gibelio/auratus & 21 & 3 & 0 & 0 & 3 \\
\hline Vissen & Rivierprik & Lampetra fluviatilis & 21 & 3 & 0 & 0 & 3 \\
\hline Vissen & Bermpje & Barbatula barbatula & 12 & 5 & 2 & 5 & 3 \\
\hline Vissen & Kleine modderkruiper & Cobitis taenia & 11 & 6 & 3 & 4 & 3 \\
\hline Vissen & Winde & Leuciscus idus & 10 & 6 & 3 & 5 & 3 \\
\hline Vissen & Karper & Cyprinus carpio & 12 & 7 & 4 & 1 & 3 \\
\hline Vissen & Zeeprik & Petromyzon marinus & 22 & 2 & 0 & 0 & 2 \\
\hline Vissen & Bot & Platichthys flesus & 22 & 2 & 0 & 0 & 2 \\
\hline Vissen & beekforel & Salmo trutta f. fario & 21 & 2 & 0 & 1 & 2 \\
\hline Vissen & Brasem/Kolblei & Abramis brama/Blicca bjoerkna & 20 & 3 & 1 & 0 & 2 \\
\hline Vissen & Zonnebaars & Lepomis gibbosus & 18 & 4 & 2 & 0 & 2 \\
\hline Vissen & Vetje & Leucaspius delineatus & 18 & 4 & 2 & 0 & 2 \\
\hline Vissen & Europese meerval & Silurus glanis & 17 & 4 & 2 & 1 & 2 \\
\hline Vissen & Roofblei & Aspius aspius & 15 & 4 & 2 & 3 & 2 \\
\hline Vissen & Rivierdonderpad & Cottus perifretum & 10 & 6 & 4 & 4 & 2 \\
\hline Vissen & Bittervoorn & Rhodeus amarus & 10 & 6 & 4 & 4 & 2 \\
\hline Vissen & Gestippelde alver & Alburnoides bipunctatus & 23 & 1 & 0 & 0 & 1 \\
\hline Vissen & Zwarte/Bruine dwergmeerval & Ameiurus melas/nebulosus & 23 & 1 & 0 & 0 & 1 \\
\hline Vissen & Donaubrasem & Ballerus sapa & 23 & 1 & 0 & 0 & 1 \\
\hline Vissen & Diklipharder & Chelon labrosus & 23 & 1 & 0 & 0 & 1 \\
\hline
\end{tabular}




\begin{tabular}{|c|c|c|c|c|c|c|c|}
\hline srtgroepen & soort_ned & soort_wet & not & vr & na & $r+n$ & vr-na \\
\hline Vissen & Kwabaal & Lota lota & 23 & 1 & 0 & 0 & 1 \\
\hline Vissen & Regenboogforel & Oncorhynchus mykiss & 23 & 1 & 0 & 0 & 1 \\
\hline Vissen & Spiering & Osmerus eperlanus & 23 & 1 & 0 & 0 & 1 \\
\hline Vissen & zeeforel & Salmo trutta f. trutta & 23 & 1 & 0 & 0 & 1 \\
\hline Vissen & Amerikaanse hondsvis & Umbra pygmaea & 23 & 1 & 0 & 0 & 1 \\
\hline Vissen & Kolblei & Blicca bjoerkna & 21 & 2 & 1 & 0 & 1 \\
\hline Vissen & Sneep & Chondrostoma nasus & 16 & 3 & 2 & 3 & 1 \\
\hline Vissen & Snoek & Esox lucius & 10 & 4 & 3 & 7 & 1 \\
\hline Vissen & Graskarper & Ctenopharyngodon idella & 22 & 1 & 1 & 0 & 0 \\
\hline Vissen & witvingrondel & Romanogobio belingi & 22 & 1 & 1 & 0 & 0 \\
\hline Vissen & Zalm & Salmo salar & 22 & 1 & 1 & 0 & 0 \\
\hline Vissen & Grote modderkruiper & Misgurnus fossilis & 21 & 1 & 1 & 1 & 0 \\
\hline Vissen & Pontische stroomgrondel & Neogobius fluviatilis & 21 & 1 & 1 & 1 & 0 \\
\hline Vissen & kopvoorn & Squalius cephalus & 16 & 1 & 1 & 6 & 0 \\
\hline Vissen & Snoekbaars & Stizostedion lucioperca & 13 & 4 & 4 & 3 & 0 \\
\hline Vissen & Brasem & Abramis brama & 10 & 4 & 4 & 6 & 0 \\
\hline Vissen & Koi-karper & Cyprinus rubrofuscus & 23 & 0 & 1 & 0 & -1 \\
\hline Vissen & Elrits & Phoxinus phoxinus & 20 & 0 & 1 & 3 & -1 \\
\hline Vissen & Kroeskarper & Carassius carassius & 21 & 1 & 2 & 0 & -1 \\
\hline Vissen & Beekprik & Lampetra planeri & 21 & 1 & 2 & 0 & -1 \\
\hline Vissen & Blauwband & Pseudorasbora parva & 16 & 2 & 3 & 3 & -1 \\
\hline Vissen & Driedoornige stekelbaars & Gasterosteus aculeatus & 5 & 5 & 6 & 8 & -1 \\
\hline Vissen & Houting & Coregonus oxyrinchus & 22 & 0 & 2 & 0 & -2 \\
\hline Vissen & Barbeel & Barbus barbus & 15 & 2 & 4 & 3 & -2 \\
\hline Vissen & Serpeling & Leuciscus leuciscus & 15 & 3 & 5 & 1 & -2 \\
\hline Vissen & Tiendoornige stekelbaars & Pungitius pungitius & 11 & 3 & 5 & 5 & -2 \\
\hline Vissen & Kesslers grondel & Neogobius kessleri & 17 & 2 & 5 & 0 & -3 \\
\hline Vissen & Rivier-/Beekprik & Lampetra fluviatilis/planeri & 20 & 0 & 4 & 0 & -4 \\
\hline Vissen & Marmergrondel & Proterorhinus semilunaris & 11 & 3 & 7 & 3 & -4 \\
\hline Vissen & Zwartbekgrondel & Neogobius melanostomus & 10 & 2 & 12 & 0 & -10 \\
\hline Vogels & Klapekster & Lanius excubitor & 17 & 6 & 0 & 1 & 6 \\
\hline Vogels & Kleine/Grote Barmsijs & Acanthis cabaret/flammea & 20 & 4 & 0 & 0 & 4 \\
\hline Vogels & Pestvogel & Bombycilla garrulus & 20 & 4 & 0 & 0 & 4 \\
\hline Vogels & Magelhaengans & Chloephaga picta & 20 & 4 & 0 & 0 & 4 \\
\hline Vogels & Taiga-/Toendrarietgans & Anser fabalis/serrirostris & 14 & 5 & 1 & 4 & 4 \\
\hline Vogels & Chinese Knobbelgans & Anser cygnoides f. domesticus & 22 & 2 & 0 & 0 & 2 \\
\hline Vogels & IJsgors & Calcarius lapponicus & 22 & 2 & 0 & 0 & 2 \\
\hline Vogels & Gestreepte Strandloper & Calidris melanotos & 22 & 2 & 0 & 0 & 2 \\
\hline Vogels & Kwartelkoning & Crex crex & 22 & 2 & 0 & 0 & 2 \\
\hline Vogels & Kievit & Vanellus vanellus & 0 & 2 & 0 & 22 & 2 \\
\hline Vogels & Roodhalsfuut & Podiceps grisegena & 19 & 3 & 1 & 1 & 2 \\
\hline Vogels & Europese Kanarie & Serinus serinus & 17 & 4 & 2 & 1 & 2 \\
\hline Vogels & Bronskopeend & Anas falcata & 23 & 1 & 0 & 0 & 1 \\
\hline Vogels & Blonde Ruiter & Calidris subruficollis & 23 & 1 & 0 & 0 & 1 \\
\hline Vogels & Manengans & Chenonetta jubata & 23 & 1 & 0 & 0 & 1 \\
\hline Vogels & Slangenarend & Circaetus gallicus & 23 & 1 & 0 & 0 & 1 \\
\hline Vogels & Draaihals & Jynx torquilla & 23 & 1 & 0 & 0 & 1 \\
\hline Vogels & Roodkopklauwier & Lanius senator & 23 & 1 & 0 & 0 & 1 \\
\hline Vogels & Ringsnavelmeeuw & Larus delawarensis & 23 & 1 & 0 & 0 & 1 \\
\hline Vogels & Dwergaalscholver & Phalacrocorax pygmeus & 23 & 1 & 0 & 0 & 1 \\
\hline Vogels & Grauwe Franjepoot & Phalaropus lobatus & 23 & 1 & 0 & 0 & 1 \\
\hline Vogels & Drieteenmeeuw & Rissa tridactyla & 23 & 1 & 0 & 0 & 1 \\
\hline Vogels & Kleine Jager & Stercorarius parasiticus & 23 & 1 & 0 & 0 & 1 \\
\hline Vogels & Poelruiter & Tringa stagnatilis & 23 & 1 & 0 & 0 & 1 \\
\hline Vogels & Hop & Upupa epops & 23 & 1 & 0 & 0 & 1 \\
\hline Vogels & Veldleeuwerik & Alauda arvensis & 1 & 1 & 0 & 22 & 1 \\
\hline Vogels & Scholekster & Haematopus ostralegus & 0 & 1 & 0 & 23 & 1 \\
\hline Vogels & Kneu & Linaria cannabina & 0 & 1 & 0 & 23 & 1 \\
\hline Vogels & Grasmus & Sylvia communis & 0 & 1 & 0 & 23 & 1 \\
\hline Vogels & Chileense Smient & Anas sibilatrix & 21 & 2 & 1 & 0 & 1 \\
\hline Vogels & Ruigpootbuizerd & Buteo lagopus & 21 & 2 & 1 & 0 & 1 \\
\hline Vogels & Rosse Stekelstaart & Oxyura jamaicensis & 21 & 2 & 1 & 0 & 1 \\
\hline Vogels & Buidelmees & Remiz pendulinus & 21 & 2 & 1 & 0 & 1 \\
\hline Vogels & Sneeuwgans & Anser caerulescens & 20 & 2 & 1 & 1 & 1 \\
\hline
\end{tabular}




\begin{tabular}{|c|c|c|c|c|c|c|c|}
\hline srtgroepen & soort_ned & soort_wet & not & vr & a & $r+n t$ & vr-na \\
\hline Vogels & Grauwe Gors & Emberiza calandra & 19 & 2 & 1 & 2 & 1 \\
\hline Vogels & Patrijs & Perdix perdix & 3 & 2 & 1 & 18 & 1 \\
\hline Vogels & Rietgors & Emberiza schoeniclus & 0 & 2 & 1 & 21 & 1 \\
\hline Vogels & Carolina-eend & Aix sponsa & 19 & 3 & 2 & 0 & 1 \\
\hline Vogels & Baardman & Panurus biarmicus & 19 & 3 & 2 & 0 & 1 \\
\hline Vogels & Grote Barmsijs & Acanthis flammea & 17 & 4 & 3 & 0 & 1 \\
\hline Vogels & Grauwe Klauwier & Lanius collurio & 15 & 5 & 4 & 0 & 1 \\
\hline Vogels & Zomertortel & Streptopelia turtur & 7 & 5 & 4 & 8 & 1 \\
\hline Vogels & Gele Kwikstaart & Motacilla flava & 1 & 0 & 0 & 23 & 0 \\
\hline Vogels & Grote Pieper & Anthus richardi & 22 & 1 & 1 & 0 & 0 \\
\hline Vogels & Roodpootvalk & Falco vespertinus & 22 & 1 & 1 & 0 & 0 \\
\hline Vogels & Poelsnip & Gallinago media & 22 & 1 & 1 & 0 & 0 \\
\hline Vogels & Bijeneter & Merops apiaster & 22 & 1 & 1 & 0 & 0 \\
\hline Vogels & Rosse Franjepoot & Phalaropus fulicarius & 22 & 1 & 1 & 0 & 0 \\
\hline Vogels & Sneeuwgors & Plectrophenax nivalis & 22 & 1 & 1 & 0 & 0 \\
\hline Vogels & Halsbandparkiet & Psittacula krameri & 22 & 1 & 1 & 0 & 0 \\
\hline Vogels & Kleine Canadese Gans & Branta hutchinsii & 21 & 1 & 1 & 1 & 0 \\
\hline Vogels & Nijlgans & Alopochen aegyptiaca & 0 & 1 & 1 & 22 & 0 \\
\hline Vogels & Grauwe Gans & Anser anser & 0 & 1 & 1 & 22 & 0 \\
\hline Vogels & Blauwe Reiger & Ardea cinerea & 0 & 1 & 1 & 22 & 0 \\
\hline Vogels & Kuifeend & Aythya fuligula & 0 & 1 & 1 & 22 & 0 \\
\hline Vogels & Buizerd & Buteo buteo & 0 & 1 & 1 & 22 & 0 \\
\hline Vogels & Kokmeeuw & Chroicocephalus ridibundus & 0 & 1 & 1 & 22 & 0 \\
\hline Vogels & Zwarte Kraai & Corvus corone & 0 & 1 & 1 & 22 & 0 \\
\hline Vogels & Meerkoet & Fulica atra & 0 & 1 & 1 & 22 & 0 \\
\hline Vogels & Fuut & Podiceps cristatus & 0 & 1 & 1 & 22 & 0 \\
\hline Vogels & Oeverpieper & Anthus petrosus & 20 & 2 & 2 & 0 & 0 \\
\hline Vogels & IJslandse Grutto & Limosa limosa islandica & 19 & 2 & 2 & 1 & 0 \\
\hline Vogels & Kuifmees & Lophophanes cristatus & 19 & 2 & 2 & 1 & 0 \\
\hline Vogels & Geelgors & Emberiza citrinella & 8 & 2 & 2 & 12 & 0 \\
\hline Vogels & Zwarte Specht & Dryocopus martius & 17 & 3 & 3 & 1 & 0 \\
\hline Vogels & Smient & Anas penelope & 0 & 3 & 3 & 18 & 0 \\
\hline Vogels & Kleine Rietgans & Anser brachyrhynchus & 13 & 5 & 5 & 1 & 0 \\
\hline Vogels & Smelleken & Falco columbarius & 11 & 5 & 5 & 3 & 0 \\
\hline Vogels & Houtsnip & Scolopax rusticola & 10 & 5 & 5 & 4 & 0 \\
\hline Vogels & Kleine Zwaan & Cygnus bewickii & 5 & 6 & 6 & 7 & 0 \\
\hline Vogels & Ralreiger & Ardeola ralloides & 23 & 0 & 1 & 0 & -1 \\
\hline Vogels & Kleinste Canadese Gans & Branta hutchinsii minima & 23 & 0 & 1 & 0 & -1 \\
\hline Vogels & Griel & Burhinus oedicnemus & 23 & 0 & 1 & 0 & -1 \\
\hline Vogels & Steltstrandloper & Calidris himantopus & 23 & 0 & 1 & 0 & -1 \\
\hline Vogels & Nachtzwaluw & Caprimulgus europaeus & 23 & 0 & 1 & 0 & -1 \\
\hline Vogels & Rosse Fluiteend & Dendrocygna bicolor & 23 & 0 & 1 & 0 & -1 \\
\hline Vogels & Roodmus & Erythrina erythrina & 23 & 0 & 1 & 0 & -1 \\
\hline Vogels & Frater & Linaria flavirostris & 23 & 0 & 1 & 0 & -1 \\
\hline Vogels & Helmparelhoen & Numida meleagris & 23 & 0 & 1 & 0 & -1 \\
\hline Vogels & Kwak & Nycticorax nycticorax & 23 & 0 & 1 & 0 & -1 \\
\hline Vogels & Kroeskoppelikaan & Pelecanus crispus & 23 & 0 & 1 & 0 & -1 \\
\hline Vogels & Chileense Flamingo & Phoenicopterus chilensis & 23 & 0 & 1 & 0 & -1 \\
\hline Vogels & Flamingo & Phoenicopterus roseus & 23 & 0 & 1 & 0 & -1 \\
\hline Vogels & Zwarte Ibis & Plegadis falcinellus & 23 & 0 & 1 & 0 & -1 \\
\hline Vogels & Noordse Goudvink & Pyrrhula pyrrhula pyrrhula & 23 & 0 & 1 & 0 & -1 \\
\hline Vogels & Lachstern & Sterna nilotica & 23 & 0 & 1 & 0 & -1 \\
\hline Vogels & Kleine Geelpootruiter & Tringa flavipes & 23 & 0 & 1 & 0 & -1 \\
\hline Vogels & Dodaars & Tachybaptus ruficollis & 1 & 0 & 1 & 22 & -1 \\
\hline Vogels & Grote Karekiet & Acrocephalus arundinaceus & 21 & 1 & 2 & 0 & -1 \\
\hline Vogels & Strandplevier & Anarhynchus alexandrinus & 21 & 1 & 2 & 0 & -1 \\
\hline Vogels & Zwaangans & Anser cygnoides & 21 & 1 & 2 & 0 & -1 \\
\hline Vogels & Ross' Gans & Anser rossii & 21 & 1 & 2 & 0 & -1 \\
\hline Vogels & IJseend & Clangula hyemalis & 21 & 1 & 2 & 0 & -1 \\
\hline Vogels & Heilige Ibis & Threskiornis aethiopicus & 21 & 1 & 2 & 0 & -1 \\
\hline Vogels & Roodkeelpieper & Anthus cervinus & 20 & 1 & 2 & 1 & -1 \\
\hline Vogels & Holenduif & Columba oenas & 1 & 1 & 2 & 20 & -1 \\
\hline Vogels & Wulp & Numenius arquata & 1 & 1 & 2 & 20 & -1 \\
\hline Vogels & Ekster & Pica pica & 1 & 1 & 2 & 20 & -1 \\
\hline
\end{tabular}




\begin{tabular}{|c|c|c|c|c|c|c|c|}
\hline srtgroepen & soort_ned & soort_wet & not & \multicolumn{3}{|c|}{ vr na vr+na } & a vr-na \\
\hline Vogels & Bosrietzanger & Acrocephalus palustris & 0 & 1 & 2 & 21 & -1 \\
\hline Vogels & Wilde Eend & Anas platyrhynchos & 0 & 1 & 2 & 21 & -1 \\
\hline Vogels & Graspieper & Anthus pratensis & 0 & 1 & 2 & 21 & -1 \\
\hline Vogels & Putter & Carduelis carduelis & 0 & 1 & 2 & 21 & -1 \\
\hline Vogels & Knobbelzwaan & Cygnus olor & 0 & 1 & 2 & 21 & -1 \\
\hline Vogels & Torenvalk & Falco tinnunculus & 0 & 1 & 2 & 21 & -1 \\
\hline Vogels & Waterhoen & Gallinula chloropus & 0 & 1 & 2 & 21 & -1 \\
\hline Vogels & Boerenzwaluw & Hirundo rustica & 0 & 1 & 2 & 21 & -1 \\
\hline Vogels & Zilvermeeuw & Larus argentatus & 0 & 1 & 2 & 21 & -1 \\
\hline Vogels & Stormmeeuw & Larus canus & 0 & 1 & 2 & 21 & -1 \\
\hline Vogels & Aalscholver & Phalacrocorax carbo & 0 & 1 & 2 & 21 & -1 \\
\hline Vogels & Rouwkwikstaart & Motacilla yarrellii & 19 & 2 & 3 & 0 & -1 \\
\hline Vogels & Eider & Somateria mollissima & 19 & 2 & 3 & 0 & -1 \\
\hline Vogels & Raaf & Corvus corax & 16 & 2 & 3 & 3 & -1 \\
\hline Vogels & Topper & Aythya marila & 15 & 2 & 3 & 4 & -1 \\
\hline Vogels & Zwarte Zwaan & Cygnus atratus & 6 & 2 & 3 & 13 & -1 \\
\hline Vogels & Kramsvogel & Turdus pilaris & 1 & 2 & 3 & 18 & -1 \\
\hline Vogels & Merel & Turdus merula & 0 & 2 & 3 & 19 & -1 \\
\hline Vogels & Duinpieper & Anthus campestris & 17 & 3 & 4 & 0 & -1 \\
\hline Vogels & Soepeend & Anas platyrhynchos domesticus & 8 & 4 & 5 & 7 & -1 \\
\hline Vogels & Wilde Zwaan & Cygnus cygnus & 8 & 4 & 5 & 7 & -1 \\
\hline Vogels & Velduil & Asio flammeus & 12 & 5 & 6 & 1 & -1 \\
\hline Vogels & Bahamapijlstaart & Anas bahamensis & 22 & 0 & 2 & 0 & -2 \\
\hline Vogels & Witoogeend & Aythya nyroca & 22 & 0 & 2 & 0 & -2 \\
\hline Vogels & Witwangstern & Chlidonias hybrida & 22 & 0 & 2 & 0 & -2 \\
\hline Vogels & Ortolaan & Emberiza hortulana & 22 & 0 & 2 & 0 & -2 \\
\hline Vogels & Grote Stern & Sterna sandvicensis & 22 & 0 & 2 & 0 & -2 \\
\hline Vogels & Kaapse Casarca & Tadorna cana & 22 & 0 & 2 & 0 & -2 \\
\hline Vogels & Smidsplevier & Vanellus armatus & 22 & 0 & 2 & 0 & -2 \\
\hline Vogels & Oeverloper & Actitis hypoleucos & 1 & 0 & 2 & 21 & -2 \\
\hline Vogels & Witvleugelstern & Chlidonias leucopterus & 20 & 1 & 3 & 0 & -2 \\
\hline Vogels & Fluiter & Phylloscopus sibilatrix & 20 & 1 & 3 & 0 & -2 \\
\hline Vogels & Kuifduiker & Podiceps auritus & 20 & 1 & 3 & 0 & -2 \\
\hline Vogels & Roerdomp & Botaurus stellaris & 19 & 1 & 3 & 1 & -2 \\
\hline Vogels & Roodkeelduiker & Gavia stellata & 19 & 1 & 3 & 1 & -2 \\
\hline Vogels & Porseleinhoen & Porzana porzana & 19 & 1 & 3 & 1 & -2 \\
\hline Vogels & Tafeleend & Aythya ferina & 1 & 1 & 3 & 19 & -2 \\
\hline Vogels & Koekoek & Cuculus canorus & 1 & 1 & 3 & 19 & -2 \\
\hline Vogels & Fazant & Phasianus colchicus & 1 & 1 & 3 & 19 & -2 \\
\hline Vogels & Kleine Karekiet & Acrocephalus scirpaceus & 0 & 1 & 3 & 20 & -2 \\
\hline Vogels & IJsvogel & Alcedo atthis & 0 & 1 & 3 & 20 & -2 \\
\hline Vogels & Krakeend & Anas strepera & 0 & 1 & 3 & 20 & -2 \\
\hline Vogels & Boomkruiper & Certhia brachydactyla & 0 & 1 & 3 & 20 & -2 \\
\hline Vogels & Vink & Fringilla coelebs & 0 & 1 & 3 & 20 & -2 \\
\hline Vogels & Tjiftjaf & Phylloscopus collybita & 0 & 1 & 3 & 20 & -2 \\
\hline Vogels & Groene Specht & Picus viridis & 0 & 1 & 3 & 20 & -2 \\
\hline Vogels & Heggenmus & Prunella modularis & 0 & 1 & 3 & 20 & -2 \\
\hline Vogels & Grote Zee-eend & Melanitta fusca & 17 & 2 & 4 & 1 & -2 \\
\hline Vogels & Glanskop & Poecile palustris & 15 & 2 & 4 & 3 & -2 \\
\hline Vogels & Blauwe Kiekendief & Circus cyaneus & 3 & 2 & 4 & 15 & -2 \\
\hline Vogels & Ringmus & Passer montanus & 1 & 2 & 4 & 17 & -2 \\
\hline Vogels & Sijs & Carduelis spinus & 4 & 3 & 5 & 12 & -2 \\
\hline Vogels & Groenling & Chloris chloris & 0 & 3 & 5 & 16 & -2 \\
\hline Vogels & Soepgans & Anser anser $\mathrm{f}$. domesticus & 5 & 4 & 6 & 9 & -2 \\
\hline Vogels & Dwerggans & Anser erythropus & 21 & 0 & 3 & 0 & -3 \\
\hline Vogels & Grauwe Kiekendief & Circus pygargus & 21 & 0 & 3 & 0 & -3 \\
\hline Vogels & Valkparkiet & Nymphicus hollandicus & 21 & 0 & 3 & 0 & -3 \\
\hline Vogels & Kleine Pelikaan & Pelecanus rufescens & 21 & 0 & 3 & 0 & -3 \\
\hline Vogels & Middelste Bonte Specht & Dendrocopos medius & 20 & 0 & 3 & 1 & -3 \\
\hline Vogels & Muskuseend & Cairina moschata & 19 & 0 & 3 & 2 & -3 \\
\hline Vogels & Steenuil & Athene vidalii & 2 & 0 & 3 & 19 & -3 \\
\hline Vogels & IJsduiker & Gavia immer & 19 & 1 & 4 & 0 & -3 \\
\hline Vogels & Brandgans & Branta leucopsis & 1 & 1 & 4 & 18 & -3 \\
\hline Vogels & Kleine Plevier & Charadrius dubius & 1 & 1 & 4 & 18 & -3 \\
\hline
\end{tabular}




\begin{tabular}{|c|c|c|c|c|c|c|c|}
\hline srtgroepen & soort_ned & soort_wet & not & vr & 1а & $r+n=$ & vr-na \\
\hline Vogels & Kolgans & Anser albifrons & 0 & 1 & 4 & 19 & -3 \\
\hline Vogels & Houtduif & Columba palumbus & 0 & 1 & 4 & 19 & -3 \\
\hline Vogels & Grote Bonte Specht & Dendrocopos major & 0 & 1 & 4 & 19 & -3 \\
\hline Vogels & Witte Kwikstaart & Motacilla alba & 0 & 1 & 4 & 19 & -3 \\
\hline Vogels & Turkse Tortel & Streptopelia decaocto & 0 & 1 & 4 & 19 & -3 \\
\hline Vogels & Zwartkop & Sylvia atricapilla & 0 & 1 & 4 & 19 & -3 \\
\hline Vogels & Bergeend & Tadorna tadorna & 0 & 1 & 4 & 19 & -3 \\
\hline Vogels & Kleine Barmsijs & Acanthis cabaret & 16 & 2 & 5 & 1 & -3 \\
\hline Vogels & Pijlstaart & Anas acuta & 2 & 2 & 5 & 15 & -3 \\
\hline Vogels & Huismus & Passer domesticus & 0 & 2 & 5 & 17 & -3 \\
\hline Vogels & Purperreiger & Ardea purpurea & 14 & 3 & 6 & 1 & -3 \\
\hline Vogels & Roodhalsgans & Branta ruficollis & 13 & 3 & 6 & 2 & -3 \\
\hline Vogels & Kruisbek & Loxia curvirostra & 13 & 3 & 6 & 2 & -3 \\
\hline Vogels & Koereiger & Bubulcus ibis & 20 & 0 & 4 & 0 & -4 \\
\hline Vogels & Ringtaling & Callonetta leucophrys & 20 & 0 & 4 & 0 & -4 \\
\hline Vogels & Keizergans & Chen canagica & 20 & 0 & 4 & 0 & -4 \\
\hline Vogels & Noordse Stern & Sterna paradisaea & 20 & 0 & 4 & 0 & -4 \\
\hline Vogels & Zwarte Zee-eend & Melanitta nigra & 19 & 0 & 4 & 1 & -4 \\
\hline Vogels & Rotgans & Branta bernicla & 18 & 0 & 4 & 2 & -4 \\
\hline Vogels & Sperwer & Accipiter nisus & 1 & 0 & 4 & 19 & -4 \\
\hline Vogels & Wintertaling & Anas crecca & 1 & 0 & 4 & 19 & -4 \\
\hline Vogels & Grote Zaagbek & Mergus merganser & 1 & 0 & 4 & 19 & -4 \\
\hline Vogels & Roodborsttapuit & Saxicola rubicola & 1 & 0 & 4 & 19 & -4 \\
\hline Vogels & Dwergstern & Sternula albifrons & 18 & 1 & 5 & 0 & -4 \\
\hline Vogels & Zeearend & Haliaeetus albicilla & 16 & 1 & 5 & 2 & -4 \\
\hline Vogels & Zilverplevier & Pluvialis squatarola & 15 & 1 & 5 & 3 & -4 \\
\hline Vogels & Bonte Vliegenvanger & Ficedula hypoleuca & 13 & 1 & 5 & 5 & -4 \\
\hline Vogels & Kwartel & Coturnix coturnix & 10 & 1 & 5 & 8 & -4 \\
\hline Vogels & Zwarte Roodstaart & Phoenicurus ochruros & 2 & 1 & 5 & 16 & -4 \\
\hline Vogels & Groenpootruiter & Tringa nebularia & 1 & 1 & 5 & 17 & -4 \\
\hline Vogels & Pimpelmees & Cyanistes caeruleus & 0 & 1 & 5 & 18 & -4 \\
\hline Vogels & Koolmees & Parus major & 0 & 1 & 5 & 18 & -4 \\
\hline Vogels & Oeverzwaluw & Riparia riparia & 0 & 1 & 5 & 18 & -4 \\
\hline Vogels & Spreeuw & Sturnus vulgaris & 0 & 1 & 5 & 18 & -4 \\
\hline Vogels & Winterkoning & Troglodytes troglodytes & 0 & 1 & 5 & 18 & -4 \\
\hline Vogels & Roek & Corvus frugilegus & 1 & 2 & 6 & 15 & -4 \\
\hline Vogels & Visdief & Sterna hirundo & 0 & 2 & 6 & 16 & -4 \\
\hline Vogels & Zanglijster & Turdus philomelos & 0 & 2 & 6 & 16 & -4 \\
\hline Vogels & Kuifaalscholver & Phalacrocorax aristotelis & 19 & 0 & 5 & 0 & -5 \\
\hline Vogels & Kleine Bonte Specht & Dendrocopos minor & 12 & 0 & 5 & 7 & -5 \\
\hline Vogels & Tapuit & Oenanthe oenanthe & 2 & 0 & 5 & 17 & -5 \\
\hline Vogels & Brilduiker & Bucephala clangula & 1 & 0 & 5 & 18 & -5 \\
\hline Vogels & Roodborst & Erithacus rubecula & 1 & 0 & 5 & 18 & -5 \\
\hline Vogels & Middelste Zaagbek & Mergus serrator & 14 & 1 & 6 & 3 & -5 \\
\hline Vogels & Goudvink & Pyrrhula pyrrhula & 10 & 1 & 6 & 7 & -5 \\
\hline Vogels & Grote Mantelmeeuw & Larus marinus & 3 & 1 & 6 & 14 & -5 \\
\hline Vogels & Grote Lijster & Turdus viscivorus & 3 & 1 & 6 & 14 & -5 \\
\hline Vogels & Staartmees & Aegithalos caudatus & 2 & 1 & 6 & 15 & -5 \\
\hline Vogels & Boomvalk & Falco subbuteo & 2 & 1 & 6 & 15 & -5 \\
\hline Vogels & Grote Zilverreiger & Ardea alba & 1 & 1 & 6 & 16 & -5 \\
\hline Vogels & Gaai & Garrulus glandarius & 0 & 1 & 6 & 17 & -5 \\
\hline Vogels & Tuinfluiter & Sylvia borin & 0 & 1 & 6 & 17 & -5 \\
\hline Vogels & Zwarte Mees & Periparus ater & 11 & 2 & 7 & 4 & -5 \\
\hline Vogels & Geelpootmeeuw & Larus michahellis & 4 & 2 & 7 & 11 & -5 \\
\hline Vogels & Braamsluiper & Sylvia curruca & 0 & 2 & 7 & 15 & -5 \\
\hline Vogels & Steltkluut & Himantopus himantopus & 18 & 0 & 6 & 0 & -6 \\
\hline Vogels & Zwarte Ooievaar & Ciconia nigra & 17 & 0 & 6 & 1 & -6 \\
\hline Vogels & Bosuil & Strix aluco & 16 & 0 & 6 & 2 & -6 \\
\hline Vogels & Vuurgoudhaan & Regulus ignicapilla & 15 & 0 & 6 & 3 & -6 \\
\hline Vogels & Boomklever & Sitta europaea & 6 & 0 & 6 & 12 & -6 \\
\hline Vogels & Waterpieper & Anthus spinoletta & 5 & 0 & 6 & 13 & -6 \\
\hline Vogels & Havik & Accipiter gentilis & 1 & 0 & 6 & 17 & -6 \\
\hline Vogels & Grote Canadese gans & Branta canadensis & 1 & 0 & 6 & 17 & -6 \\
\hline Vogels & Witgat & Tringa ochropus & 1 & 0 & 6 & 17 & -6 \\
\hline
\end{tabular}




\begin{tabular}{|c|c|c|c|c|c|c|}
\hline srtgroepen & soort_ned & soort_wet & not & vr na & $r+n e$ & vr-na \\
\hline Vogels & Waterral & Rallus aquaticus & 10 & 17 & 6 & -6 \\
\hline Vogels & Ransuil & Asio otus & 9 & 17 & 7 & -6 \\
\hline Vogels & Nachtegaal & Luscinia megarhynchos & 8 & 17 & 8 & -6 \\
\hline Vogels & Nonnetje & Mergellus albellus & 3 & 17 & 13 & -6 \\
\hline Vogels & Koperwiek & Turdus iliacus & 3 & 17 & 13 & -6 \\
\hline Vogels & Spotvogel & Hippolais icterina & 1 & 17 & 15 & -6 \\
\hline Vogels & Ooievaar & Ciconia ciconia & 0 & 17 & 16 & -6 \\
\hline Vogels & Kauw & Corvus monedula & 0 & 17 & 16 & -6 \\
\hline Vogels & Zwarte Wouw & Milvus migrans & 12 & 28 & 2 & -6 \\
\hline Vogels & Krooneend & Netta rufina & 12 & 28 & 2 & -6 \\
\hline Vogels & Dwergmeeuw & Hydrocoloeus minutus & 11 & 28 & 3 & -6 \\
\hline Vogels & Boomleeuwerik & Lullula arborea & 10 & 28 & 4 & -6 \\
\hline Vogels & Matkop & Poecile montanus & 5 & 28 & 9 & -6 \\
\hline Vogels & Sprinkhaanzanger & Locustella naevia & 4 & 28 & 10 & -6 \\
\hline Vogels & Casarca & Tadorna ferruginea & 4 & 39 & 8 & -6 \\
\hline Vogels & Kleine Mantelmeeuw & Larus fuscus & 4 & 410 & 6 & -6 \\
\hline Vogels & Grutto & Limosa limosa & 4 & 07 & 13 & -7 \\
\hline Vogels & Visarend & Pandion haliaetus & 4 & 07 & 13 & -7 \\
\hline Vogels & Grote Gele Kwikstaart & Motacilla cinerea & 3 & 07 & 14 & -7 \\
\hline Vogels & Slobeend & Anas clypeata & 1 & 07 & 16 & -7 \\
\hline Vogels & Watersnip & Gallinago gallinago & 1 & 07 & 16 & -7 \\
\hline Vogels & Steenloper & Arenaria interpres & 14 & 18 & 1 & -7 \\
\hline Vogels & Wielewaal & Oriolus oriolus & 12 & 18 & 3 & -7 \\
\hline Vogels & Rode Wouw & Milvus milvus & 11 & 18 & 4 & -7 \\
\hline Vogels & Goudplevier & Pluvialis apricaria & 9 & 18 & 6 & -7 \\
\hline Vogels & Kleine Zilverreiger & Egretta garzetta & 5 & 18 & 10 & -7 \\
\hline Vogels & Bruine Kiekendief & Circus aeruginosus & 3 & 18 & 12 & -7 \\
\hline Vogels & Tureluur & Tringa totanus & 1 & 18 & 14 & -7 \\
\hline Vogels & Krombekstrandloper & Calidris ferruginea & 11 & 29 & 2 & -7 \\
\hline Vogels & Beflijster & Turdus torquatus & 11 & 29 & 2 & -7 \\
\hline Vogels & Stadsduif & Columba livia f. domestica & 9 & 29 & 4 & -7 \\
\hline Vogels & Kraanvogel & Grus grus & 4 & 29 & 9 & -7 \\
\hline Vogels & Mandarijneend & Aix galericulata & 8 & 310 & 3 & -7 \\
\hline Vogels & Slechtvalk & Falco peregrinus & 2 & 411 & 7 & -7 \\
\hline Vogels & Reuzenstern & Hydroprogne caspia & 16 & 08 & 0 & -8 \\
\hline Vogels & Rosse Grutto & Limosa lapponica & 14 & 08 & 2 & -8 \\
\hline Vogels & Appelvink & Coccothraustes coccothraustes & 6 & 08 & 10 & -8 \\
\hline Vogels & Bokje & Lymnocryptes minimus & 13 & 19 & 1 & -8 \\
\hline Vogels & Kanoet & Calidris canutus & 11 & 19 & 3 & -8 \\
\hline Vogels & Kleine Strandloper & Calidris minuta & 11 & 19 & 3 & -8 \\
\hline Vogels & Kerkuil & Tyto alba & 9 & 19 & 5 & -8 \\
\hline Vogels & Wespendief & Pernis apivorus & 3 & 19 & 11 & -8 \\
\hline Vogels & Zomertaling & Anas querquedula & 2 & 19 & 12 & -8 \\
\hline Vogels & Paapje & Saxicola rubetra & 1 & 19 & 13 & -8 \\
\hline Vogels & Fitis & Phylloscopus trochilus & 0 & 19 & 14 & -8 \\
\hline Vogels & Grauwe Vliegenvanger & Muscicapa striata & 4 & 210 & 8 & -8 \\
\hline Vogels & Geoorde Fuut & Podiceps nigricollis & 14 & 09 & 1 & -9 \\
\hline Vogels & Engelse Kwikstaart & Motacilla flavissima & 13 & 09 & 2 & -9 \\
\hline Vogels & Huiszwaluw & Delichon urbicum & 1 & 09 & 14 & -9 \\
\hline Vogels & Zwarte Stern & Chlidonias niger & 6 & 110 & 7 & -9 \\
\hline Vogels & Toendrarietgans & Anser serrirostris rossicus & 2 & 110 & 11 & -9 \\
\hline Vogels & Zwarte Ruiter & Tringa erythropus & 4 & 211 & 7 & -9 \\
\hline Vogels & Noordse Kwikstaart & Motacilla thunbergi & 5 & 010 & 9 & -10 \\
\hline Vogels & Indische Gans & Anser indicus & 3 & 010 & 11 & -10 \\
\hline Vogels & Gierzwaluw & Apus apus & 1 & 010 & 13 & -10 \\
\hline Vogels & Keep & Fringilla montifringilla & 4 & 111 & 8 & -10 \\
\hline Vogels & Kemphaan & Calidris pugnax & 3 & 111 & 9 & -10 \\
\hline Vogels & Zwartkopmeeuw & Larus melanocephalus & 9 & 212 & 1 & -10 \\
\hline Vogels & Rietzanger & Acrocephalus schoenobaenus & 6 & 212 & 4 & -10 \\
\hline Vogels & Temmincks Strandloper & Calidris temminckii & 11 & 011 & 2 & -11 \\
\hline Vogels & Regenwulp & Numenius phaeopus & 6 & 011 & 7 & -11 \\
\hline Vogels & Boompieper & Anthus trivialis & 5 & 112 & 6 & -11 \\
\hline Vogels & Gekraagde Roodstaart & Phoenicurus phoenicurus & 5 & 112 & 6 & -11 \\
\hline Vogels & Kluut & Recurvirostra avosetta & 4 & 112 & 7 & -11 \\
\hline
\end{tabular}




\begin{tabular}{|c|c|c|c|c|c|c|}
\hline srtgroepen & soort_ned & soort_wet & not & vr $n$ & $v r+n$ & vr-na \\
\hline Vogels & Bosruiter & Tringa glareola & 4 & 112 & 7 & -11 \\
\hline Vogels & Drieteenstrandloper & Calidris alba & 11 & 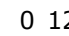 & 1 & -12 \\
\hline Vogels & Goudhaan & Regulus regulus & 7 & 012 & 5 & -12 \\
\hline Vogels & Bonte Strandloper & Calidris alpina & 4 & 012 & 8 & -12 \\
\hline Vogels & Blauwborst & Luscinia svecica & 4 & 012 & 8 & -12 \\
\hline Vogels & Lepelaar & Platalea leucorodia & 4 & 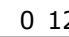 & 8 & -12 \\
\hline Vogels & Pontische Meeuw & Larus cachinnans & 4 & 113 & 6 & -12 \\
\hline Vogels & Bontbekplevier & Charadrius hiaticula & 3 & 116 & 4 & -15 \\
\hline Zoogdieren & Aardmuis & Microtus agrestis & 18 & 6 & 0 & 6 \\
\hline Zoogdieren & Gewone/Tweekleurige bosspitsmuis & Sorex araneus/coronatus & 12 & 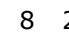 & 2 & 6 \\
\hline Zoogdieren & Watervleermuis & Myotis daubentonii & 16 & 5 & 3 & 5 \\
\hline Zoogdieren & Rosse woelmuis & Myodes glareolus & 13 & 72 & 2 & 5 \\
\hline Zoogdieren & Meervleermuis & Myotis dasycneme & 20 & 4 & 0 & 4 \\
\hline Zoogdieren & Huisspitsmuis & Crocidura russula & 12 & 62 & 4 & 4 \\
\hline Zoogdieren & Dwergspitsmuis & Sorex minutus & 20 & 3 & 1 & 3 \\
\hline Zoogdieren & Gewone bosspitsmuis & Sorex araneus & 22 & 2 & 0 & 2 \\
\hline Zoogdieren & Tweekleurige bosspitsmuis & Sorex coronatus & 22 & 2 & 0 & 2 \\
\hline Zoogdieren & Woelrat/Molmuis & Arvicola amphibius/scherman & 21 & 2 & 1 & 2 \\
\hline Zoogdieren & Baardvleermuis & Myotis mystacinus & 21 & 2 & 1 & 2 \\
\hline Zoogdieren & Huismuis & Mus domesticus & 20 & 3 & 0 & 2 \\
\hline Zoogdieren & Waterspitsmuis & Neomys fodiens & 23 & 1 & 0 & 1 \\
\hline Zoogdieren & Wasbeer & Procyon lotor & 23 & 1 & 0 & 1 \\
\hline Zoogdieren & Hermelijn & Mustela erminea & 19 & 2 & 2 & 1 \\
\hline Zoogdieren & Gewone grootoorvleermuis & Plecotus auritus & 17 & 2 & 4 & 1 \\
\hline Zoogdieren & Beverrat & Myocastor coypus & 17 & 43 & 0 & 1 \\
\hline Zoogdieren & Rosse vleermuis & Nyctalus noctula & 12 & 52 & 3 & 1 \\
\hline Zoogdieren & Franjestaart & Myotis nattereri & 22 & 0 & 2 & 0 \\
\hline Zoogdieren & Baardvleermuis / Brandts vleermuis & Myotis mystacinus/brandtii & 20 & 0 & 4 & 0 \\
\hline Zoogdieren & Damhert & Dama dama & 22 & 1 & 0 & 0 \\
\hline Zoogdieren & Bunzing & Mustela putorius & 19 & 2 & 1 & 0 \\
\hline Zoogdieren & Gewone/Grijze grootoorvleermuis & Plecotus auritus/austriacus & 18 & 3 & 0 & 0 \\
\hline Zoogdieren & Egel & Erinaceus europaeus & 4 & 4 & 12 & 0 \\
\hline Zoogdieren & Gewone dwergvleermuis & Pipistrellus pipistrellus & 3 & 4 & 13 & 0 \\
\hline Zoogdieren & Laatvlieger & Eptesicus serotinus & 12 & 5 & 2 & 0 \\
\hline Zoogdieren & Veldmuis & Microtus arvalis & 8 & 5 & 6 & 0 \\
\hline Zoogdieren & Bosmuis & Apodemus sylvaticus & 10 & 6 & 2 & 0 \\
\hline Zoogdieren & Boommarter & Martes martes & 23 & 0 & 0 & -1 \\
\hline Zoogdieren & Gewone zeehond & Phoca vitulina & 23 & 0 & 0 & -1 \\
\hline Zoogdieren & Wild zwijn & Sus scrofa & 21 & 0 & 1 & -2 \\
\hline Zoogdieren & Muskusrat & Ondatra zibethicus & 17 & 1 & 3 & -2 \\
\hline Zoogdieren & Ruige dwergvleermuis & Pipistrellus nathusii & 15 & 3 & 1 & -2 \\
\hline Zoogdieren & Eekhoorn & Sciurus vulgaris & 12 & 3 & 4 & -2 \\
\hline Zoogdieren & Steenmarter & Martes foina & 11 & 3 & 5 & -2 \\
\hline Zoogdieren & Huiskat & Felis catus & 19 & 1 & 0 & -3 \\
\hline Zoogdieren & Dwergmuis & Micromys minutus & 11 & 4 & 2 & -3 \\
\hline Zoogdieren & Das & Meles meles & 14 & 0 & 6 & -4 \\
\hline Zoogdieren & Bruine rat & Rattus norvegicus & 5 & 4 & 7 & -4 \\
\hline Zoogdieren & Haas & Lepus europaeus & 2 & 1 & 15 & -5 \\
\hline Zoogdieren & Ree & Capreolus capreolus & 6 & 3 & 7 & -5 \\
\hline Zoogdieren & Konijn & Oryctolagus cuniculus & 2 & 0 & 16 & -6 \\
\hline Zoogdieren & Wezel & Mustela nivalis & 11 & 2 & 2 & -7 \\
\hline Zoogdieren & Vos & Vulpes vulpes & 2 & 2 & 11 & -7 \\
\hline Zoogdieren & Mol & Talpa europaea & 3 & 1 & 11 & -8 \\
\hline Zoogdieren & Bever & Castor fiber & 1 & 01 & 11 & -12 \\
\hline
\end{tabular}


Wageningen Environmental Research Postbus 47

6700 AA Wageningen

T 0317480700

www.wur.nl/environmental-research

Wageningen Environmental Research

Rapport 2873

ISSN 1566-7197
De missie van Wageningen University \& Research is 'To explore the potential of nature to improve the quality of life'. Binnen Wageningen University \& Research bundelen Wageningen University en gespecialiseerde onderzoeksinstituten van Stichting Wageningen Research hun krachten om bij te dragen aan de oplossing van belangrijke vragen in het domein van gezonde voeding en leefomgeving. Met ongeveer 30 vestigingen, 5.000 medewerkers en 10.000 studenten behoort Wageningen University \& Research wereldwijd tot de aansprekende kennisinstellingen binnen haar domein. De integrale benadering van de vraagstukken en de samenwerking tussen verschillende disciplines vormen het hart van de unieke Wageningen aanpak. 



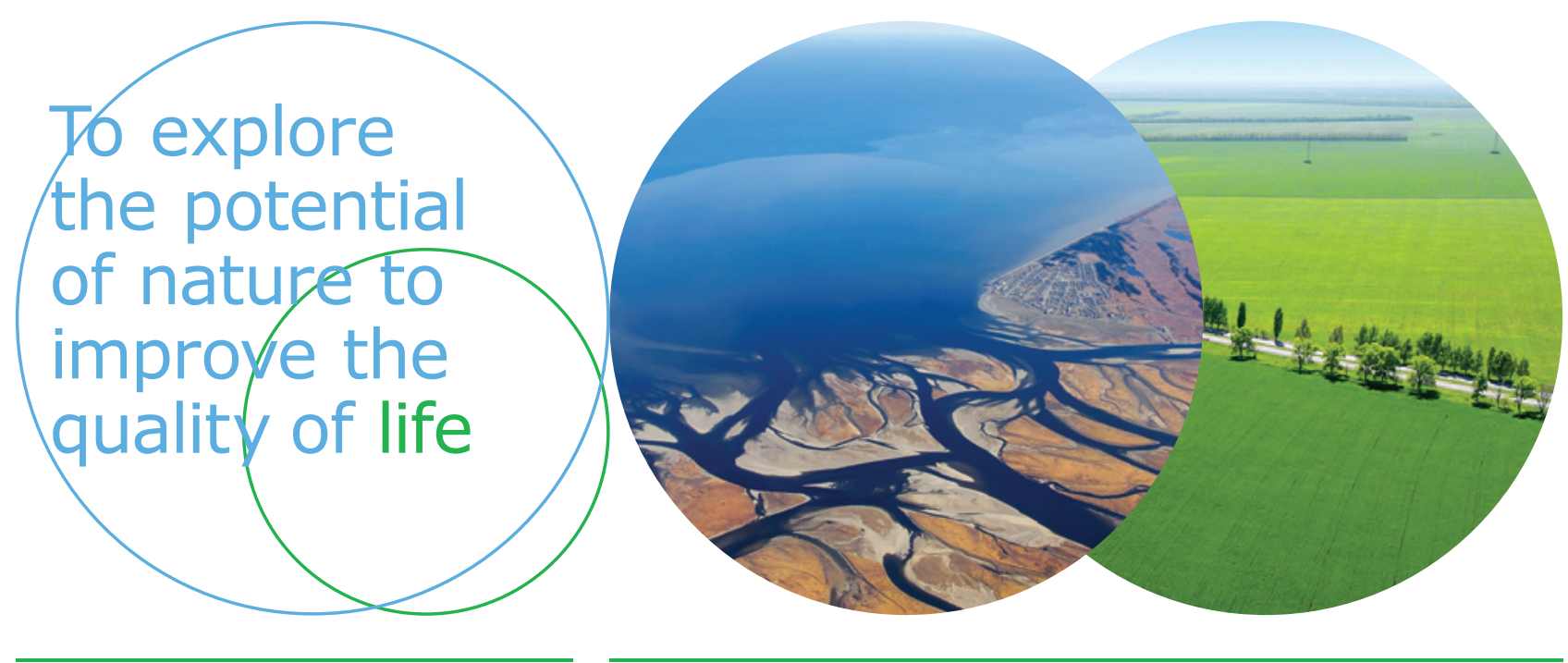

Wageningen Environmental Research Postbus 47

$6700 \mathrm{AB}$ Wageningen

T 317480700

www.wur.nl/environmental-research

Rapport 2873

ISSN 1566-7197
De missie van Wageningen University \& Research is 'To explore the potential of nature to improve the quality of life'. Binnen Wageningen University \& Research bundelen Wageningen University en gespecialiseerde onderzoeksinstituten van Stichting Wageningen Research hun krachten om bij te dragen aan de oplossing van belangrijke vragen in het domein van gezonde voeding en leefomgeving. Met ongeveer 30 vestigingen, 5.000 medewerkers en 10.000 studenten behoort Wageningen University \& Research wereldwijd tot de aansprekende kennisinstellingen binnen haar domein. De integrale benadering van de vraagstukken en de samenwerking tussen verschillende disciplines vormen het hart van de unieke Wageningen aanpak. 